\begin{tabular}{|l|l|}
\hline $\begin{array}{l}\text { 2. To: (Receiving Organization) } \\
\text { TWRS }\end{array}$ & $\begin{array}{l}\text { 3. From: (originating organization) } \\
\text { ICF KH }\end{array}$ \\
\hline 5. Proj./Prog./Dept./Div.: & $\begin{array}{l}\text { 6. Cog. Engr-: } \\
\text { R. L. Ackerman }\end{array}$ \\
\hline $\begin{array}{l}\text { 8. Originator Remarks: } \\
\text { This document addresses the results of the simulated riser }\end{array}$ \\
installation field testing activities and recommendations \\
for future riser installations in SSTs by the use of rotary \\
drilling equipment. For original release.
\end{tabular}

11. Receiver Remarks:

\begin{tabular}{|c|c|c|c|}
\hline \multicolumn{4}{|c|}{$\begin{array}{r}\text { 4. Related EDT No:: } \\
\text { N/A }\end{array}$} \\
\hline \multicolumn{4}{|c|}{$\begin{array}{r}\text { 7. Purchase order No.: } \\
\qquad N / A \\
\end{array}$} \\
\hline \multicolumn{4}{|c|}{$\begin{array}{l}\text { 9. Equip./Component No.: } \\
\qquad N / A\end{array}$} \\
\hline \multicolumn{4}{|c|}{ 10. System/Bldg./Facility: } \\
\hline \multicolumn{4}{|c|}{$\begin{array}{l}\text { 12. Major Assm. Dwg. No.: } \\
\qquad N / A\end{array}$} \\
\hline \multicolumn{4}{|c|}{$\begin{array}{l}\text { 13. Permit/Permit Application No.: } \\
N / A\end{array}$} \\
\hline \multicolumn{4}{|c|}{$\begin{array}{l}\text { 14. Required Response Date: } \\
\text { N/A }\end{array}$} \\
\hline (F) & (G) & (H) & (I) \\
\hline $\begin{array}{l}\text { Approval } \\
\text { Desig- } \\
\text { nator }\end{array}$ & $\begin{array}{l}\text { Reason } \\
\text { for } \\
\text { Trans- } \\
\text { mittal }\end{array}$ & $\begin{array}{l}\text { Origi- } \\
\text { nator } \\
\text { Dispo- } \\
\text { sition }\end{array}$ & $\begin{array}{l}\text { Receiv- } \\
\text { er } \\
\text { Dispo- } \\
\text { sition }\end{array}$ \\
\hline$N / A$ & 1 & 1 & 1 \\
\hline & & & \\
\hline & & & \\
\hline & & & \\
\hline & & & \\
\hline Dispositi & O(H) \& (I) & & \\
\hline $\begin{array}{l}\text { ment } \\
\text { imment }\end{array}$ & $\begin{array}{l}\text { Reviewe } \\
\text { Reviewe } \\
\text { Receipt }\end{array}$ & $\begin{array}{l}\text { o/comm } \\
\text { N/comm } \\
\text { knowled }\end{array}$ & \\
\hline
\end{tabular}

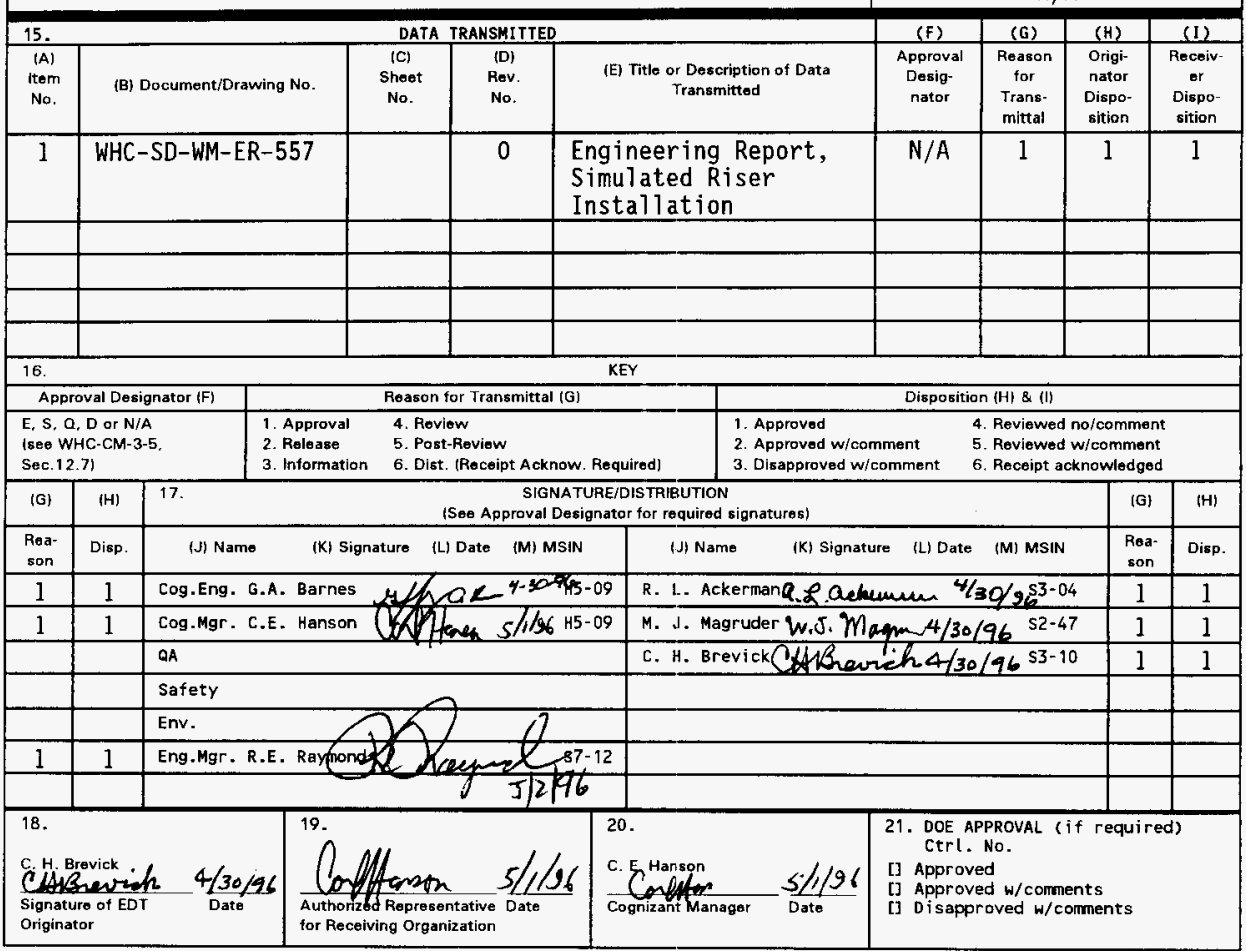




\title{
Engineering Report for Simulated Riser Installation
}

\author{
C. H. Brevick \\ R. L. Ackerman \\ W. J. Magruder \\ ICF Kaiser Hanford Company, Richland, WA 99352 \\ U.S. Department of Energy Contract DE-AC06-87RL10930
}

$\begin{array}{lll}\text { EDT } / \text { ECN: } & 612791 & \text { UC: } 2070 \\ \text { Org Code: } & 5 \text { A400 } & \text { Charge Code: E20017 } \\ \text { B\&R Code: } & \text { EW3120074 } & \text { Total Pages: } 1 \mathcal{B} /\end{array}$

Key Words: Riser, riser installation, riser simulation, rotary drilling, core drilling, core barrel, casing shoe, vacuum excavation

Abstract: The simulated riser installation field tests demonstrated that new access ports (risers) can be installed safely, quickly, and economically in the concrete domes of existing underground single-shell waste storage tanks by utilizing proven rotary drilling equipment and vacuum excavation techniques. The new riser installation will seal against water intrusion, provide a stable riser anchored to the tank dome, and be installed in accordance with ALARA principles. The information contained in the report will apply to actual riser installation activity in the future.

TRADEMARK DISCLAIMER. Reference herein to any specific commercial product, process, or service by trade name, trademark, manufacturer, or otherwise, does not necessarily constitute or imply its endorsement, recommendation, or favoring by the United States Government or any agency thereof or its contractors or subcontractors.

Printed in the United States of America. To obtain copies of this document, contact: WHC/BCS Document Control Services, P.O. Box 1970, Mailstop H6-08, Richtand WA 99352, Phone (509) 372-2420; Fax (509) $376-4989$.
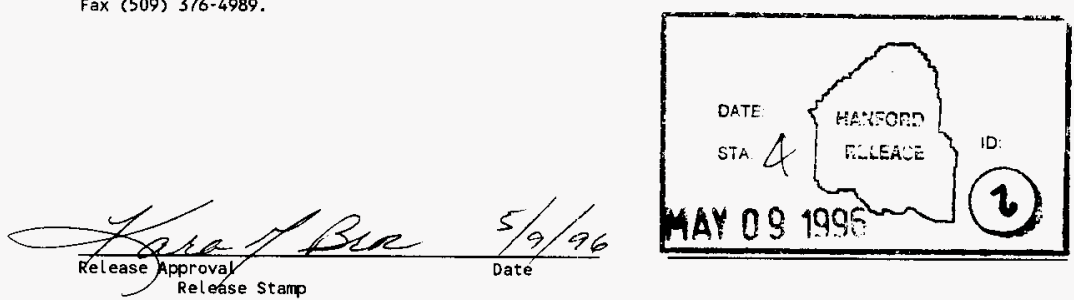

\section{Approved for Public Release}




\title{
ENGINEERING REPORT \\ SIMULATED RISER INSTALLATION \\ WORK ORDER E20017
}

\author{
Prepared for \\ Westinghouse Hanford Company
}

April 1996

Subcontract WHC 380393

Prepared by

ICF Kaiser Hanford Company

Richland, Washington

E20017ER 
WHC-SD-WM-ER-557, Rev. 0

E20017ER

ENGINEERING REPORT

FOR

SIMULATED RISER INSTALLATION

WORK ORDER E20017

Prepared by.

ICF Kaiser Hanford Company

Richland, Washington

for

Westinghouse Hanford Company

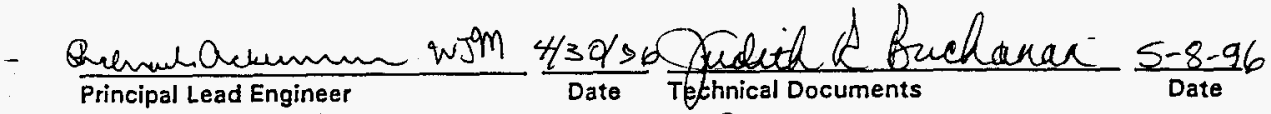

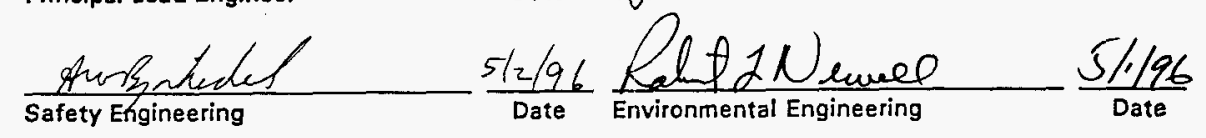

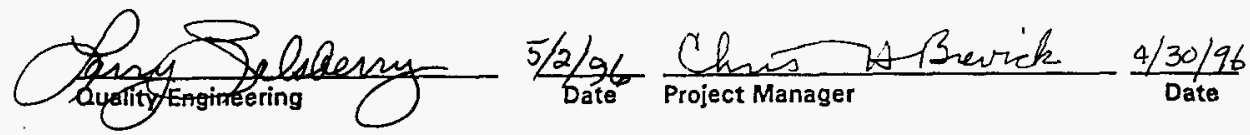

Westinghouse Hanford Company

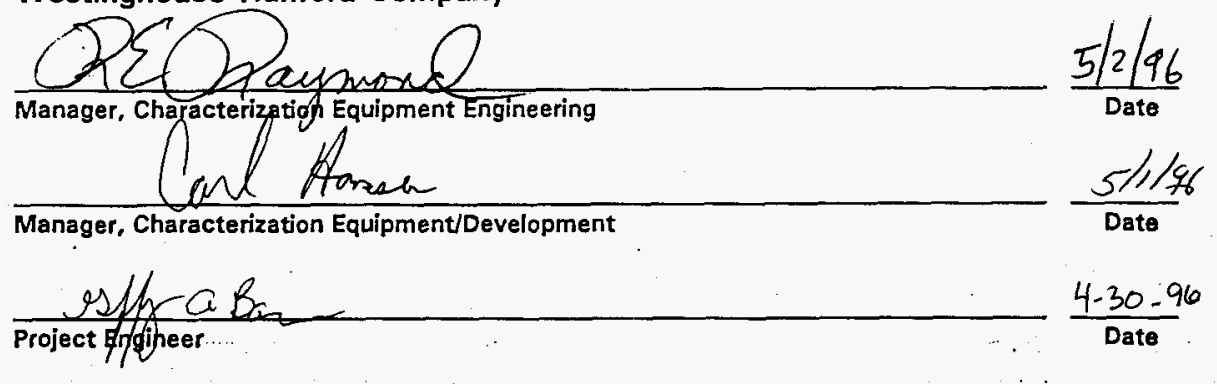

$-\mathbf{i}-$ 


\section{EXECUTIVE SUMMARY}

The Hanford Site has 149 underground high-level radioactive waste storage tanks of the single-shell design with access to the waste for sampling or retrieval through vertical pipes called risers. A limited number of existing risers are available on the single-shell tanks (SSTs) due to the early design and to the utilization by pumps, sensors, and other equipment. Future sampling and waste retrieval activities may require installation of additional risers in the SSTs.

An engineering study, "Installation of New Risers in Single-Shell Tanks," conducted during Fiscal Year 1994 identified the rotary drilling method as the preferred alternative for a new riser installation in SSTs. To test out the preferred alternative, an activity plan to simulate a riser installation by using rotary drilling was developed and approved during Fiscal Year 1995.

Field test activities began in December 1995 at the 100-C Area using the aged concrete of an abandoned piping tunnel. A rotary drill rig, drilling tools, and bits were obtained and a high-powered vacuum truck was utilized to perform excavation and cleanup of cuttings. Other constructionrelated equipment, such as a boom truck, portable welder, and a generator, were also obtained.

Four rotary drilling demonstrations were performed on existing hatch cover blocks to test out the core drilling technique close at hand. The four demonstrations consisted of the following:

- Cut a groove in a hatch cover block to accept a 450-mm (18-in.) inner casing. Set an inner casing in the groove and seal with grout.

- Repeat the above procedure on a second block, set a core-retaining anchor, and core a $345-\mathrm{mm}$ (14-1/2-in.) hole through the block.

- Repeat the above two procedures on a third block. Retract the core plug.

- Set a cover block on a 10-degree slope similar to that of a tank dome. Perform the three previous procedures to test the drilling and coring equipment performance on a sloped surface. Install a $300-\mathrm{mm}(12$-in.) riser.

The fifth demonstration was designed to represent an actual installation of a riser into the dome of an SST. A vertical column of compacted soil was installed in a section of $1220-\mathrm{mm}(48$-in.) culvert installed upright in the piping tunnel. The steps to simulate a riser installation in a tank dome are:

- Excavate the compacted soil with a high-powered vacuum truck.

- Place a $600-\mathrm{mm}$ (24-in.) outer casing as the excavation advances the $3000 \mathrm{~mm}(10 \mathrm{ft})$ to the simulated dome.

- Use the outer casing as a guide for the 450-mm (18-in.) bit to cut a $75-\mathrm{mm}$ (3-in.) groove in the simulated dome.

- Vacuum out the cuttings, place an appropriate length of inner casing, and grout the casing. 
- Use the inner casing as a guide to:

- Drill and anchor a rod or pipe to the core area with epoxy

- Core drill through the simulated dome

- Remove the core barrel bit and the core plug

- Install a prefabricated riser, grout between the riser and casing, and pour a cement pad. The simulated riser installation is complete.

The drilling times for cutting the groove for the casing, drilling the anchor hole, or coring through concrete the thickness of an SST dome took less than 1-1/2 hours.

The cuttings and excess cooling water were vacuumed out before the final coring was performed. The water usage was restricted to $19 \mathrm{~L}(5 \mathrm{gal})$ of cooling water during the final few inches of coring through a dome.

The testing showed that it is technically feasible to install $300-\mathrm{mm}(12$-in.) risers on existing SSTs. However, before an actual riser installation in an SST can be performed, the following work must be completed.

- Perform a safety analysis for the entire riser installation process

- Obtain State and Federal permits

- Prepare detailed engineering design and analysis

- Prepare detailed work procedures

- Establish a riser installation schedule

- Authorize funding for the actual riser installation

The total time required to install a new riser in the dome of an SST is estimated to be 1 year. The safety analysis, permitting, engineering, planning, scheduling, and training is estimated to require 10-1/2 months. The tank farm site preparation, equipment mobilization, riser fabrication, riser installation, and demobilization is estimated to require 1-1/2 months. The actual field excavation, rotary coring and riser installation activity can be accomplished in a little over a 3-week period.

From updated cost information and experience gained in the simulated riser installation field test activities, the cost to install the first new riser is estimated to be $\$ 1,035,000$. After the first riser is installed, the estimated cost to install each additional riser will be $\$ 250,000$. With the addition of the permitting, environmental assessment, and safety analysis costs, the current riser installation estimate is only slightly higher than the rotary drilling alternative estimate in the engineering study. 


\section{TABLE OF CONTENTS}

I. INTRODUCTION $\ldots \ldots \ldots \ldots \ldots \ldots \ldots \ldots \ldots \ldots \ldots \ldots$

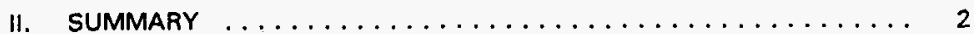

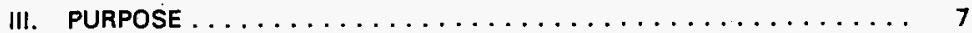

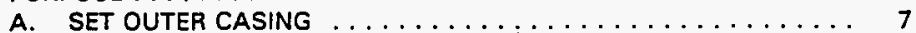

B. SET INNER CASING $\ldots \ldots \ldots \ldots \ldots \ldots \ldots \ldots \ldots \ldots \ldots$

C. RETENTION ROD OR PIPE PLACEMENT ............ 8

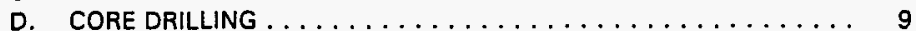

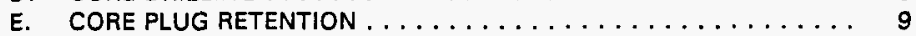

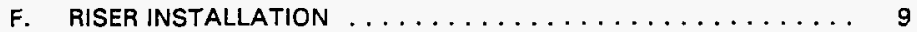

G. EQUIPMENT, INSTRUMENTS, AND SUPPLIES . . . . . . . . 10

IV. DESCRIPTION ....................... 10

A. MODIFICATIONS TO ENGINEERING STUDY CONCEPTS . . . . . . . 10

B. EXISTING AGED CONCRETE FOR THE DEMONSTRATIONS . . . 11

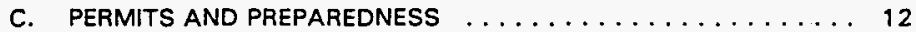

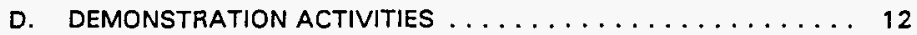

1. Preliminary Test, Trial Drilling Activities ............ 13

2. Demonstration 1: Setting and Grouting of Inner Casing . . . 15

3. Demonstration 2: Set Retention Pipe and Core Drill Two Cover Blocks ........................ 16

4. Demonstration 3: Core Drill One Cover Block ......... 18

5. Demonstration 4: Install 12-in. Riser on Sloped Cover Block . 19

6. Demonstration 5: Simulated Riser Installation in Soil Column . 22

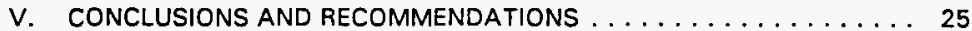

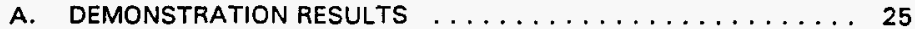

1. Setting Outer Casing . . . . . . . . . . . . . . . 25

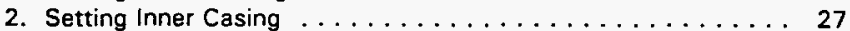

3. Setting Retention Device ................. 30

4. Core Barrel Performance ................. 32

5. Installation Riser ................... 33

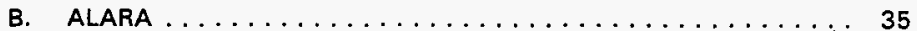

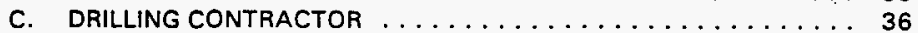

D. INSTALLATION OF LARGER RISERS $\ldots \ldots \ldots \ldots \ldots \ldots \ldots \ldots$

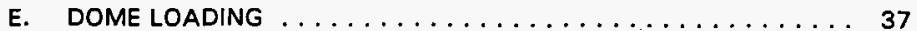

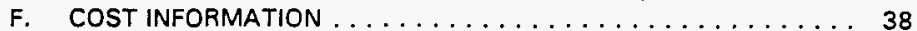

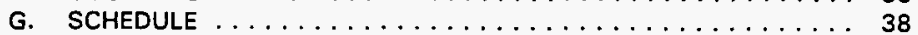

VI. REFERENCES $\ldots \ldots \ldots \ldots \ldots \ldots \ldots \ldots \ldots \ldots \ldots \ldots$ 


\section{APPENDICES}

Appendix A. Data Sheets

Appendix B. Daily Activity Log

Appendix C. Selected Photos

Appendix D. Equipment and Supplies

Appendix E. New Riser Cost Information

Appendix F. New Riser Installation Schedule

Appendix G. Procedure Outline

Appendix H. Selected Portions of Engineering Study

Appendix I. Rotary Drilling Test Plan Notations 


\section{ABBREVIATIONS}

$\begin{array}{ll}\text { ALARA } & \text { as low as reasonably achievable } \\ \text { BHI } & \text { Bechtel Hanford, Inc. } \\ \text { CMP } & \text { corrugated metal pipe } \\ \text { D\&D } & \text { decontamination and decommissioning } \\ \text { DOE } & \text { U.S. Department of Energy } \\ \text { ICF KH } & \text { ICF Kaiser Hanford Company } \\ \text { JSA } & \text { job safety analysis } \\ \text { NWJ } & \begin{array}{l}\text { a generic designation for a type of hollow-steel } \\ \text { drill rod }\end{array} \\ \text { PVC } & \text { polyvinyl chloride } \\ \text { SST } & \text { single-shell tank } \\ \text { USACE } & \text { U.S. Army Corps of Engineers } \\ \text { WHC } & \text { Westinghouse Hanford Company }\end{array}$




\section{GLOSSARY}

Casing Shoe: A coring bit made of diamond-embedded matrix blocks attached by brazing to a $450-\mathrm{mm}$ (18-in.) diameter machined steel pipe ring. The casing shoe is welded to a length of the same diameter pipe and becomes a drilling tool. It cuts a $13-\mathrm{mm}(1 / 2-i n$.) wide groove into the reinforced concrete.

Core Barrel: A coring bit made of diamond-embedded matrix blocks attached by brazing to a $368-\mathrm{mm}(14.5$-in.) diameter machined steel ring. The ring is threaded to a length of steel barrel which is in turn threaded to a cap. The cap mates with NWJ drill rod subadapter which rotates the core barrel unit. The core barrel will core to a depth of $600 \mathrm{~mm}(24 \mathrm{in}$.) and cuts a $13-\mathrm{mm}(1 / 2-\mathrm{in}$.$) wide groove into the reinforced concrete.$

Guzzler: A truck-mounted high volume vacuum unit used for conveying soil and drilling cuttings. The Guzzler vacuum system had an airflow capacity up to 197,400 LPM $(7,000 \mathrm{cfm})$ and draws up to $686 \mathrm{~mm}$ (27 in.) $\mathrm{Hg}$ of vacuum. The unit includes a collection tank and a four-stage filtration system to minimize airborne contaminations. A drum filling attachment is available.

Inner Casing: 450 mm (18 in.) ASTM A 106, Standard Weight Pipe.

Medium $48 \mathrm{~mm}$ (1.89-in.) drill bit: A carbide-embedded full hole bit, $48 \mathrm{~mm}$ (1.89 in.) diameter with a $76-\mathrm{mm}$ (3-in.) hollow adapter for NWJ drill rod.

Mobile Drill 61 HD: A mobile drill rig of the rotary drilling type.

Outer Casing: 600 mm (24 in.) ASTM A 106, Standard Weight Pipe.

Riser: $300 \mathrm{~mm}$ (12 in.) ASTM A 106, Standard Weight Pipe.

Small 25-mm (1-in.) drill bit: A diamond-embedded full hole bit, $24 \mathrm{~mm}$ ( 1 in.) diameter with a $387-\mathrm{mm}$ (16-in.) long, hollow shank and adapter for NWJ drill rod.

Subadapter: A hardened steel adapter to couple tapered-thread NWJ drill rod to the straight thread of the core barrel cap. 


\section{TRADEMARK INFORMATION}

The following equipment, instrument, and supplies are listed as registered trademarks.

Guzzler: Guzzler Manufacturing Inc., Birmingham, Alabama.

Mobile Drill 61 HD: Mobile Drilling Company, Inc., Indianapolis, Indiana.

Lincoln Welder: Lincoln Electric Company, Inc., Cleveland, Ohio.

Hilti Epoxy Capsule: Hilti, Inc., Tulsa, Oklahoma.

Masterflow 928: Master Builders, Cleveland, Ohio.

Five Star Epoxy: Five Star Products, Inc., Fairfield, Connecticut.

Standard Type 1 and II Cement: Ash Grove Cement Company, Inc., Overland Park, Kansas.

Ametek Model 1726: Ametek, Inc., Mansfield \& Green Division, Largo, Florida. 


\section{ENGINEERING REPORT \\ SIMULATED RISER INSTALLATION \\ WORK ORDER E20017}

\section{INTRODUCTION}

Westinghouse Hanford Company (WHC) is conducting a waste characterization program to characterize the waste contained in single-shell tanks (SSTS) on the Hanford Site. Sampling of waste requires access to the interior of the SSTs through vertical pipes called risers. Many of the underground SSTs do not have sufficient access pipes (risers), or the risers are not in optimum locations for sampling. WHC directed ICF Kaiser Hanford Company (ICF KH) to conduct demonstrations to determine if rotary drilling techniques could be used to install new risers in SSTs.

In December 1995 and early January 1996, ICF KH conducted demonstrations at the 100-C Reactor area to simulate riser installation. The demonstration results were positive. Existing rotary drilling techniques and equipment were used to core drill through simulated SST domes. Risers were set in cored holes and grouted in place. The demonstrations proved that the risers can be set efficiently with minimum exposure to potential radiation contamination.

Before an actual riser installation in an SST can be performed, the following work will be required:

- Perform a safety analysis for the entire riser installation process

- Obtain State and Federal permits

- Prepare detailed engineering design and analysis

- Prepare detailed work procedures

- Establish a riser installation schedule

- Authorize funding for the actual riser installation 
The need for new risers in SSTs is discussed in an engineering study, "Installation of New Risers in Single-Shell Tanks," (Appendix H, pages 1 through 8) (ref 1). The report describes several alternatives for installing SST risers and rotary drilling was found to be the least expensive alternative (Appendix H, page 13).

In January 1995, the U.S. Army Corps of Engineers (USACE) and WHC held a two-day technical workshop on sampling system improvements. A portion of the workshop included a review of the riser installation engineering study and a draft of the "Activity Plan for a Simulated Riser Installation by Use of Rotary Drilling," prepared by ICF KH (ref 2).

Information from the riser installation engineering study, comments from panelists attending the January 1995 USACE workshop, (ref 3), and details from subsequent meetings between WHC and ICF KH were utilized to prepare a final rotary drilling test plan. This plan was detailed in Appendix $\mathrm{F}$ of the activity plan (ref 2). The activity plan outlined the steps involved in conducting a simulated riser installation and was followed for the field testing, except for minor variations as shown by notations to the Rotary Drilling Test Plan isee Appendix 1).

\section{SUMMARY}

Simulated riser installation field tests demonstrated that by utilizing proven drilling equipment and techniques, new risers could be installed in existing concrete domes in the single-shell tanks (SSTs). The risers could be installed quickly, economically, and safely in accordance with environmental regulations and as-low-as-reasonably-achievable (ALARA) principles.

To prove the ability of a rotary drill rig to core drill through concrete, a series of four demonstrations were performed on the $2100-\mathrm{mm}(7-\mathrm{ft})$ long by $863-\mathrm{mm}$ (34-in.) wide by $229-\mathrm{mm}$ (9-in.) thick hatch cover blocks from the piping tunnel (see Figure 1). The reinforced concrete cover blocks have two lavers of 


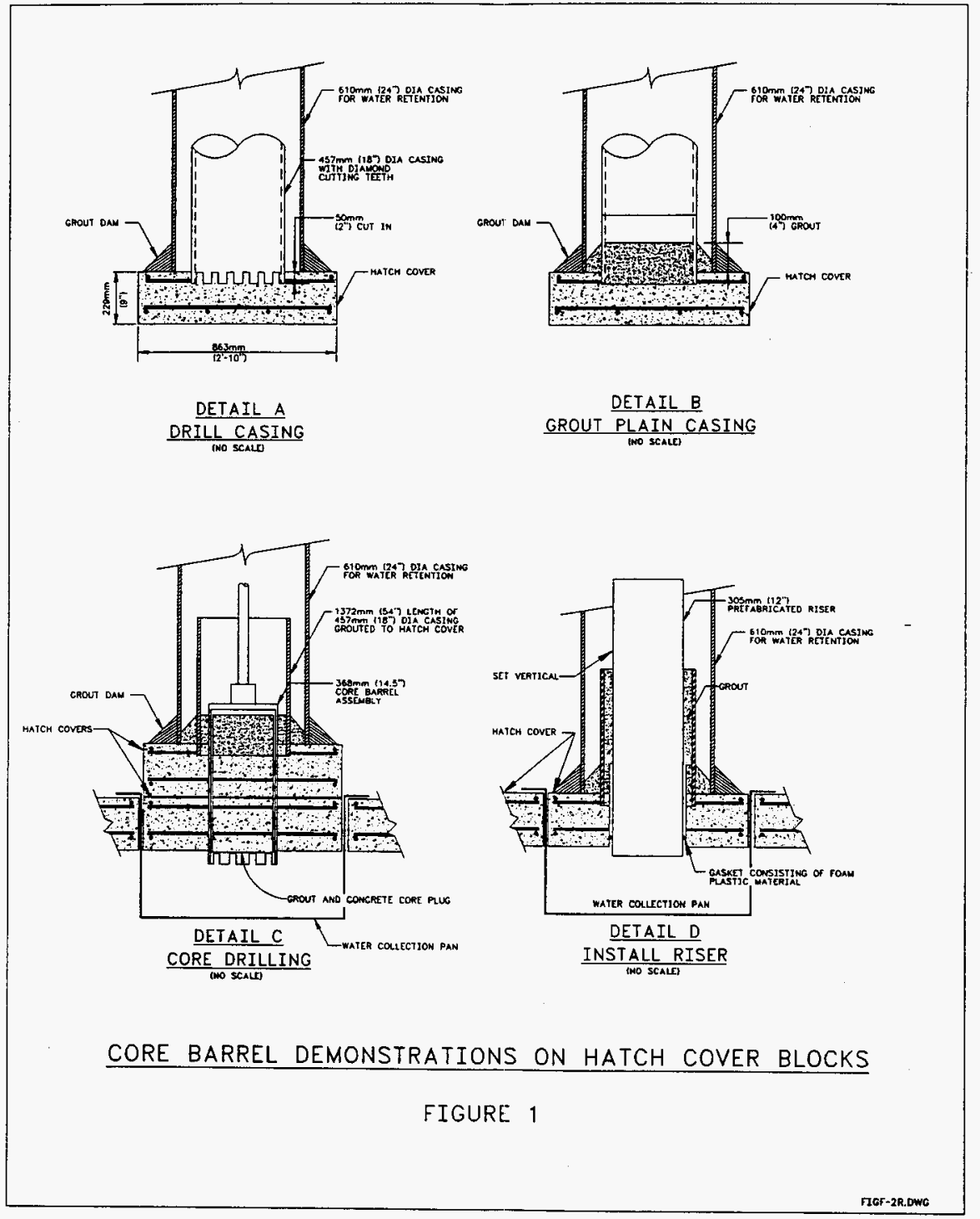


reinforcement bars and are of similar age as the SST domes. The cover blocks have lifting points which allows the blocks to be removed from the tunnel and set aside for future study once the field tests are complete (see photo 1 , Appendix C).

Short lengths of $600-\mathrm{mm}$ (24-in.) diameter casing were attached to the cover blocks and sealed to provide cooling water reservoirs and a guide for the casing shoe (see photo 2, Appendix C).

The rotary drill rig, the high volume truck-mounted vacuum, the boom truck and other related equipment were assembled at the field test site. As a trial run, a preliminary test was conducted with the drilling equipment (see photo 3 , Appendix C).

The first field demonstration consisted of cutting a 50- $\mathrm{mm}$ (2-in.) deep groove into a cover block with a 450-mm (18-in.) diameter casing shoe bit (see photos 4 and 5, Appendix C). A short length of standard weight $450-\mathrm{mm}(18-\mathrm{in}$.) inner casing was placed into the groove and sealed in with grout (see photos 6 and 7 , Appendix C). The second demonstration consisted of performing the initial two steps on two stacked cover blocks. After the inner casing was set and the grout had cured, a 25-mm (1-in.) hole was drilled through the blocks for a retention rod (see photo 8, Appendix $\mathrm{C}$ ). When the retention rod was secure, both blocks were cored through with the core barrel bit (see photo 9, Appendix C).

The third demonstration involved the previous steps but only cored through one cover block.

The fourth demonstration involved the grooving for the casing, setting the retention pipe, core drilling, and setting a 300-mm (12-in.) riser on a cover block that sloped about 10 degrees (see photo 10, Appendix C). 
Demonstration 5 provided an opportunity to utilize the Guzzler, a high-volume truck-mounted vacuum system, for excavation of $1.1 \mathrm{~m}^{3}\left(1.5 \mathrm{yd}^{3}\right)$ of compacted soil over a simulated tank dome. The vacuum system allowed the placement of a $3350 \mathrm{~mm}(11 \mathrm{ft}$ ) length of a $600-\mathrm{mm}(24-i n$.$) outer casing in$ compacted soil in an 8-hr shift. The compacted soil, composed of $76 \mathrm{~mm}$ ( $3 \mathrm{in}$.) minus grade of structural fill, contained cobble rocks, gravel, and sand and is similar to soil found in the SST farms (see photo 11 ). (All photos are shown in Appendix C.)

Once set, the outer casing retained the soil, provided access to the simulated tank dome and acted as a guide for cutting a groove in the dome with the casing shoe coring bit (see photos 12 and 13).

The rotary drill rig provided the motive force to cut a $50-\mathrm{mm}$ (2-in.) deep groove with a 450-mm (18-in.) diameter, diamond-tipped casing shoe into the simulated tank dome in approximately 30 minutes. The groove allowed the $450-\mathrm{mm}$ (18-in.) inner casing to be set and grouted to the simulated tank dome. The inner casing established a water seal for cooling water and cuttings during the coring activity. It provides a guide for drilling a $25-\mathrm{mm}$ ( 1 -in.) diameter hole into the simulated tank dome for the core plug retention anchor pipe. The inner casing also provided a guide for centering the 368-mm (14-1/2-in.) core barrel bit during the coring activity.

The rotary drill rig turned the 368-mm (14-1/2-in.) diameter core barrel bit with ease and control. The diamond-tipped core barrel cut through a $432-\mathrm{mm}$ (17-in.) thickness of double-reinforced concrete, similar to that of a tank dome, in approximately 1-1/2 hours (see photo 14 ).

The casing shoe, the small $25-\mathrm{mm}(1-\mathrm{in}$.$) bit and the core barrel required cooling$ water addition of approximately $1.89 \mathrm{~L} / \mathrm{min}(1 / 2 \mathrm{gal} / \mathrm{min})$ to remove the cuttings and keep the diamond embedded matrix blocks cool. Before the core barrel bit cut all the way through the simulated dome, the coring activity was stopped. 
Then, the cooling water and cuttings were removed with the vacuum truck. Only $18.9 \mathrm{~L}$ ( 5 gal) of cooling water was used for the final few inches of coring through the simulated dome. On an actual SST dome coring activity, a similar amount of cooling water would be used and lost into the tank as the core barrel bit penetrated through the remaining concrete layer.

The core plug was successfully retained within the core barrel bit by the core retaining pipe which passed within the NWJ drill rod and was held by a cable hoist on the rotary drill rig (see photo 15 ). The core plug and core barrel were removed together from the inner casing to an elevation where the drill rig was able to move away from the drill site. This allowed for removal of the core plug from the core barrel under more favorable conditions. Access was then provided through the inner casing for the prefabricated riser installation.

A gasket of polyurethane foam material was placed around the riser near the bottom end with wire and adhesive (see photo 16 ). When the riser was installed, the foam material conformed to the annular area between the outside of the riser and the interior of the cored hole. This provided a dam for the grout. An initial layer of grout was added to the annular space between the riser and the cored hole. Once the initial grout hardened, more grout was added to make a water-tight seal between the inner casing and the riser.

Loadbearing clips were welded between the riser and the inner casing. Therefore, any weight placed upon the riser would be transferred directly to the tank dome through the inner casing. With additional grout placed in the annular area, between the inner and outer casing, the whole installation would be very stable and secure. The clips also held the riser vertically while the grout setup.

From the experience gained in the simulated riser installation field activities with the rotary drilling, it appears that a riser actually can be installed in the dome of a SST in a little over 3 weeks, allowing time for the curing of grout and the epoxy anchor. 
The tank farm site preparation, equipment mobilization, riser fabrication, riser field installation, and demobilization is estimated to require $1-1 / 2$ months. The safety analysis, permitting, engineering, planning, scheduling, and training is estimated to require $10-1 / 2$ months. The total project time for the riser installation process is estimated to be 1 year.

\section{PURPOSE}

The objective of the simulated riser installation was to determine if rotary drilling equipment and techniques, along with the use of a powerful vacuum truck to excavate and confine potentially contaminated materials, could be used to set risers in SSTS. Demonstration results will be used to establish criteria for type of drill rig, drill bits, wear on bits, drill speed, and cooling water requirements. The types of grout and grouting techniques, setting and sealing risers, and estimated time to complete each stage of the process will be evaluated. The information gained will be used for actual riser installations.

Also, the demonstration results will determine the usefulness of vacuum excavation methods for setting large diameter casings, handling of excess cooling water and cleanup of cuttings.

The technique for retaining and handling the core plug will be tested.

The specific demonstrations and objectives in the simulated riser installation were designed to address the following questions and determinations:

\section{A. SET OUTER CASING}

- Can the vacuum equipment excavate the compacted fill expected over the SSTS, for the setting of an 600-mm (24-in.) outer casing up to $3350 \mathrm{~mm}$ (11 $\mathrm{ft}$ ) long?

- Can the outer casing be lowered by gravity into the excavated hole to contact a simulated tank dome? 
- Is an external power source, such as a vibrator, required to drive the outer casing into the excavated hole?

- Is it necessary to fill voids on the outside of the outer casing after the casing is set?

- Can the outer casing act as a guide for placement of the inner casing?

\section{B. SET INNER CASING}

- Can a 450-mm (18-in.) casing shoe (see photo 4) drill a circular groove 51 to $76 \mathrm{~mm}$ ( 2 to 3 in.) deep into a sloped, simulated tank dome?

- Can an 450-mm (18-in.) inner casing be set in the groove and be grouted into the concrete to form a seal?

- Can the grout seal confine drilling cooling water and cuttings inside the casing?

- Would waterproofing, welded wire fabric, and gunite which is expected on the outside of specific SST domes, interfere with the grout seal and require removal before installation of the inner casing?

\section{RETENTION ROD OR PIPE PLACEMENT}

- Can a 19-mm (3/4-in.) solid rod retain the core plug and be functional during core drilling? Would a pipe of similar diameter function better?

- Can a $15-\mathrm{mm}(1 / 2-$ in.) diameter pipe be set with epoxy in a $25-\mathrm{mm}$ $(1$-in.) diameter hole that is drilled at the center of the inner casing and into the simulated dome (see photos 8 and 29)? 
- Can the pipe act as a conduit for cooling water during core drilling and as a retainer for the core?

- Can epoxy used to bond the retaining pipe to the concrete be installed easily, cured, and develop sufficient strength to retain the core?

D. CORE DRILLING

- Can a 368-mm (14-1/2-in.) outer-diameter core barrel (see photo 9) cut through sloped, reinforced concrete up to $457 \mathrm{~mm}$ (18 in.) thick without excessive wear?

- How much cooling water is required for core drilling?

- How can the core barrel be kept centered in the inner casing during core drilling?

\section{E. CORE PLUG RETENTION}

- Determine possible wear or damage to the retaining rod or the pipe from the drill stem or core barrel fittings.

- Can the core retention system prevent the core plug from falling when the coring is complete?

- Can both the core barrel and core plug be withdrawn from the simulated dome without failing?

\section{F. RISER INSTALLATION}

- Can a riser be set plumb in the inner casing and cored hole?

- Can a foam gasket attached to the outside of the riser retain grout with minimal leakage until the grout cures (see photo 16)? 
- Will the grout seal be watertight?

- Can the grout resist a vertical load?

\section{G. EQUIPMENT, INSTRUMENTS, AND SUPPLIES}

- What equipment, materials, and supplies are necessary for setting the risers?

- What measuring devices are necessary to control and monitor the work, such as revolution/time meters, flow meters, pressure gauges, calipers, thermometers, and tape measures?

\section{DESCRIPTION}

\section{A. MODIFICATIONS TO ENGINEERING STUDY CONCEPTS}

The riser simulation test demonstrations are similar to the riser installation concepts developed in the engineering study (ref 1). Comments from the USACE workshop were included (ref 3 ). After the drilling and excavating equipment was received, the test: plan for the simulated riser installation was further developed. The following modifications were made to the engineering study concepts:

- Instead of setting a 400-mm (16-in.) hollow-stem augur to the top of the tank dome or, as in the case of Option B (page 17 of the USACE Report), placing a 400-mm (16-in.) casing inside a 500-mm (20-in.) hollow-stem augured hole, the simulation test demonstration utilized a standard weight $600-\mathrm{mm}$ (24-in.) pipe for the outer casing. The outer casing was set by use of a vacuum truck. The $450-\mathrm{mm}$ (18-in.) inner casing was grouted into the simulated dome. Using vacuum methods of excavation and casing placement, potentially contaminated soil can be confined within the vacuum truck and not be augured out onto the ground. Also, any potential for damaging 
existing underground utilities would be minimized by using a vacuum excavation method instead of an augur.

- Instead of relying on a steel collar and gasket around the $300-\mathrm{mm}$ (12-in.) riser to seal to the new grout inside the $450-\mathrm{mm}$ (18-in.) inner casing, a new riser support and sealing concept was developed. A polyurethane gasket was placed around the bottom end of the riser and grout was placed between the riser and the inside of the cored hole in the simulated tank dome to seal the riser to the dome. In this way, the seal is not dependent on the adherence of new grout to the existing concrete (new grout did not adhere well to existing concrete in the demonstrations).

- The grout seal is now located between the new riser and the newly cored concrete. This extends the grout into the cored hole and covers the exposed reinforcement bar. The transfer of the load between the riser and the dome is accomplished by clips welded between the top of the riser and the inner casing. The grout in the annular areas between the two casing and the riser also sustain the load.

\section{B. EXISTING AGED CONCRETE FOR THE DEMONSTRATIONS}

Uncontaminated reinforced-concrete tunnels that were used for cooling water piping for the 100-C Reactor were used for the demonstrations. The reinforced concrete in these tunnels is similar in age and reinforcement to the concrete found in the domes of the SSTs. Numerous concrete hatch cover blocks from the tunnel provided individual demonstration examples that could be retained for further study. The depth of the piping tunnel was $3000 \mathrm{~mm}$ (10 ft) from the surface. A column of compacted soil placed in the tunnel was similar to the fill over the dome of a SST. 
Correspondence concerning the use of the piping tunnels, between ICF KH and the Bechtel Hanford, Inc. (BHI) Decontamination and Decommissioning group in October and November 1995, resolved any potential conflicts between BHI efforts to demolish the 193-C filter complex and 180-C pumphouse and the ICF $\mathrm{KH}$ riser simulation test demonstration in the same area.

\section{PERMITS AND PREPAREDNESS}

No other permits, besides the Categorical Exclusion were required to begin field testing. Job safety analyses (JSA) of the simulated riser test demonstration activities were required, as for any field work.

Other preparation included revising and approval of the activity plan (ref 2). Ordering drilling bits, grout, pipe, instruments, and miscellaneous supplies was addressed. Obtaining the use of the drill rig, boom truck, vacuum truck, and other construction equipment was arranged. Special drilling tools and a cooling water collection tub were fabricated in the 100-N shop. Preparatory field work included setting the short lengths of $600-\mathrm{mm}$ (24-in.) outer casings on cover blocks to act as cooling water reservoirs, setting the $1220-\mathrm{mm}$ (48-in.) corrugated metal pipe (CMP) in the pipe tunnel, and filling the CMP with compacted soil.

\section{DEMONSTRATION ACTIVITIES}

The field demonstration activities and schedule were based upon Revision 1 of the Activity Plan (ref 2). Field testing began December 7 , 1995 and was completed on January 4, 1996. The equipment and supplies used during the field testing activities are listed in Appendix D. Demonstration activities and summaries for the preliminary test and five planned demonstrations are as follows: 


\section{Preliminary Test, Trial Drilling Activities}

\section{Summary}

A preliminary test was added to the scope to ensure that assumptions about equipment and techniques established for the five demonstrations detailed in the activity plan were reasonable and that major modifications were not necessary.

A short length of outer casing was bolted down to a reinforced-concrete hatch cover block and sealed with asphalt sealant to provide cooling water retention for the trial drilling activities.

The preliminary test consisted of setting and grouting a short length of inner casing into the 229-mm (9-in.) thick concrete hatch cover, drilling a $25-\mathrm{mm}(1-\mathrm{in}$.$) diameter hole in the concrete hatch cover$ and setting a 19-mm (3/4-in.) diameter core retention rod with epoxy in the hole. When the epoxy was cured, the preliminary test proceeded with core drilling through the cover block.

Date Started: December 5, 1995

Date Completed: December 12, 1995

\section{Results}

Measurements and observations were recorded on test data sheets (Appendix A) and in daily field notes (Appendix B). The results of the main preliminary test activities are recorded as follows:

- Casing Shoe: The 450-mm (18-in.) casing shoe drilled a $51-\mathrm{mm}$ (2-in.) deep groove into the hatch cover block in 30 minutes with 37.8- $(10-\mathrm{gal})$ cooling water. It drilled another $63 \mathrm{~mm}(2-1 / 2 \mathrm{in}$.$) in 20$ minutes with some addition of cooling water due to leaks in the asphalt sealant. 
- Grout: A quantity of $28.4 \mathrm{~L}(7.5$ gal) of Masterflow 928, grout was placed inside both the inner and outer casings as the inner casing was placed into the groove.

- Setting Retention Rod: A 25-mm (1-in.) hole was drilled to a depth of $102 \mathrm{~mm}$ (4 in.) into the grout and $25 \mathrm{~mm}$ (1 in.) into the cover block. The small $25-\mathrm{mm}(1-\mathrm{in}$.) drill bit broke in two places. The top end failed in the thin wall of the threads, and the bit end failed in the thin wall connection (see photo 29 ).

- The $19-\mathrm{mm}$ (3/4-in.) diameter rod was set with epoxy into the hole in the grout and into the shallow hole in the concrete. The epoxy adhered to the rod, but the grout did not bond to the concrete, therefore, the circular grout plug pulled free from the concrete.

- Small Drill Bit: The failed small bit was sent out for repair and a spare bit was ordered. The bit was repaired by machining the NWJ adapter, inserting steel tubes into the shank and welding the bit together. No damaged was done to the tip (see photo 31 ).

- Core Barrel: Drilled $305 \mathrm{~mm}(1 \mathrm{ft}$ ) into the grout and cover block. Used $75.7 \mathrm{~L}$ (20 gal) of water. Water and cuttings were vacuumed out to inspect the core drilling progress. The last $38 \mathrm{~mm}$ (1-1/2 in.) of coring was finished and the core plug was dropped to the bottom of the tunnel since the retaining rod was only anchored in the grout layer. About $18.9 \mathrm{~L}(5 \mathrm{gal})$ of cooling water was used to finish the coring. 


\title{
2. Demonstration 1: Setting and Grouting of Inner Casing
}

\begin{abstract}
Summary
Demonstration 1 as listed in the Activity Plan (ref 1) consisted of setting and grouting an inner casing to a concrete hatch cover. An outer casing was bolted to the hatch cover block and sealed with grout to provide cooling water retention and to act as a guide for centering the casing shoe bit. Refer to Appendix I for the amended steps followed in conducting Demonstration 1, for the revised drawings, and for the marked-up illustrations that recorded changes during the demonstration.
\end{abstract}

Date Started: December 12, 1995

Date Completed: December 13, 1995

\section{Results}

The following measurements and observations were recorded for Demonstration 1.

- Casing Shoe: The 450-mm (18-in.) diameter casing shoe drilled a $51-\mathrm{mm}(2-\mathrm{in}$.$) deep groove into the cover block in$ 17 minutes, using $26.4 \mathrm{~L}$ (7 gal) of cooling water.

- Grout: Used 28.4 L (7.5 gal) of Standard Type I and II cement grout in the annular area between the inner and outer casing. The inner casing was set by working the grout into the groove by rocking and slightly lifting the inner casing. The grout cured for 8 hours. Water leakage through the grout was $4 \%$ of volume in 24 hours. The desired condition was to have no leakage around the inner casing. 
3. Demonstration 2: Set Retention Pipe and Core Drill Two Cover Blocks

\section{Summary}

Demonstration 2 included all the elements of Demonstration 1, plus installing a $15-\mathrm{mm}(1 / 2-\mathrm{in}$.) diameter pipe into the center of the core for core retention. The pipe also provided a cooling water conduit for drilling with the core barrel. Two 229-mm (9-in.) thick cover blocks were stacked and strapped together to provide a $450-\mathrm{mm}$ (18-in.) thick block to core drill through. No grout was used to seal between the cover blocks.

Using the two cover blocks was a deviation from Demonstration 2 of the Rotary Drilling Test Plan.

Refer to Appendix I for the amended steps followed in conducting Demonstration 2, for the revised drawings, and for the marked-up illustrations that recorded changes during the demonstration.

Date Started: December 15, 1995

Date Completed: December 19, 1995

\section{Results}

The following measurements and observations were recorded for Demonstration 2.

- Casing Shoe: The 450-mm (18-in.) diameter casing shoe drilled a $51-\mathrm{mm}(2-\mathrm{in}$.$) deep groove into the cover block in$ 10 minutes, using $15 \mathrm{~L}$ (4 gal) of cooling water.

- Grout: Used $15 \mathrm{~L}$ (4 gal) of Masterflow 928 grout between inner and outer casings only. Little or no grout was allowed 
to flow into the center area of the inner casing during the setting of the inner casing.

No leakage of water from the annular area between the casings to the inside of the inner casing was detected.

- Setting Retention Pipe: Used the repaired 25-mm (1-in.) drill, and drilled $330 \mathrm{~mm}$ (13 in.) in 75 minutes, using $18.9 \mathrm{~L}$ (5 gal) of cooling water. An open-ended $15-\mathrm{mm}(1 / 2-\mathrm{in}$.$) pipe was$ installed in the hole with epoxy. The pipe failed the pull test because most of the epoxy was inside the pipe since the end of the pipe was open. In later demonstrations, the end of the pipe was closed to correct this problem.

- Core Barrel: The core barrel cored through $330 \mathrm{~mm}(13 \mathrm{in.)}$ of the two stacked cover blocks in 75 minutes. A total of $227 \mathrm{~L}$ (60 gal) of cooling water was used. Most of the water leaked between the two cover blocks since they were not grouted together. One diamond/matrix segment from the core barrel bit was broken loose as the drill bound up when it was about $178 \mathrm{~mm}(7 \mathrm{in.})$ into the bottom block. The core from the top block was also moving in the core barrel because there was no restraint.

After coring was finished, it was found that a sliver of rebar approximately 9.5 by 6.3 by $77 \mathrm{~mm}$ (3/8 by $1 / 4$ by 3 in.) was loose in the groove inside of the core barrel. Either of these events may have loosened the diamond/matrix segment, but Christensen Mining Products, the vendor who supplied the core barrel, indicated that tangential slivers of reinforcement bar have come loose from the cores and bound up core bits 
before (see photo 17). The core barrel was repaired onsite by reattaching the diamond/matrix segment with brazing.

\title{
4. Demonstration 3: Core Drill One Cover Block
}

\begin{abstract}
Summary
Demonstration 3 was planned to include all elements of Demonstration 2, plus setting a riser. However, because of scheduling changes, Demonstrations 4 and 5 preceded Demonstration 3 . In both Demonstrations 4 and 5 , risers were set so Demonstration 3 did not include setting the riser. Refer to Appendix I for a description of the demonstrations, the modifications to the demonstrations, the revised drawings, and the marked-up illustrations for this demonstration.
\end{abstract}

Date Started: December 14, 1995

Date Completed: January 3, 1996

\section{Results}

The following measurements and observations were recorded in Demonstration 3:

- Casing Shoe: The 450-mm (18-in.) casing shoe drilled a $51-\mathrm{mm}$ (2-in.) deep groove into the block in 8 minutes, using $15 \mathrm{~L}$ (4 gal) of cooling water.

- Grout: Approximately $22.7 \mathrm{~L}(6 \mathrm{gal})$ of Five Star epoxy grout was placed between the inner and outer casings. The inner casing was set by rocking the casing side to side to allow the grout to flow into the groove. The grout was allowed to cure. No leakage occurred during 24-hour water test. 
- Setting Retention Pipe: Drilled $254 \mathrm{~mm}$ (10 in.) into the grout and cover block with the $25-\mathrm{mm}(1-$ in.) drill in 45 minutes. Used $15 \mathrm{~L}$ (4 gal) of cooling water. Successfully pull tested the pipe at 4.2-kN (950-lb) after the epoxy was set and cured (see photos 19 and 29).

- Core Barrel: Drilled $102 \mathrm{~mm}$ (4 in.) into the grout and $203 \mathrm{~mm}$ ( 8 in.) into a cover block in 50 minutes. Used $68 \mathrm{~L}$ (18 gal) of cooling water for the initial coring activity. The dirty cooling water and cuttings were vacuumed out. Used only $3.7 \mathrm{~L}$ (1 gal) of cooling water to finish last $25 \mathrm{~mm}$ (1 in.) of coring. The grout adhered to the concrete core. The retention pipe held the core and the pipe and the core were removed with the core barrel (see photos 20,21, and 22). No riser was installed.

\section{Demonstration 4: Install 12-in. Riser on Sloped Cover Block}

\section{Summary}

Demonstration 4 included elements of Demonstration 3 , plus setting of the 300-mm (12-in.) riser. The cover block was sloped nearly 10 degrees and was covered by building paper, welded wire fabric, and grout to more nearly replicate the water-proofing material that covers some domes of the SSTs (see photo 10). The outer casing was set in a vertical configuration with angle brackets and grout to provide a cooling water retention basin. Refer to Appendix I for a description of Demonstration 4 , the modifications to the demonstration, the revised drawings, and the marked-up illustrations of the demonstration.

Date Started: December 20, 1995

Date Completed: December 28, 1995 


\section{Results}

The following measurements and observations were recorded in Demonstration 4.

- Casing Shoe: The 450-mm (18-in.) casing shoe drilled a 152-mm (6-in.) deep groove on the high side of the sloped cover block in 30 minutes. A total of $208 \mathrm{~L}$ (55 gal) of cooling water was circulated from the outer casing to a trough and back. Recovered $151 \mathrm{~L}$ (40 gal) of water. The circular piece of building paper, welded wire fabric, and grout came out in one piece after it had been cut through by the casing shoe. Used the $48-\mathrm{mm}(1.89$-in.) drill bit and ripper to lay back the remaining building paper, welded wire fabric, and grout layer near the inner wall of the outer casing for a better grout bond. Took 30 minutes to chip out the remaining grout. Finished cutting the groove with the casing shoe to a depth of $13 \mathrm{~mm}$ $(1 / 2$ in. $)$ on the low side of the sloped block.

- Grout: Used about $22.7 \mathrm{~L}(6 \mathrm{gal})$ of Five Star epoxy grout inside the inner and outer casings. No leakage was detected during the 24-hour water test.

- Setting Retention Pipe: The 25-mm (1-in.) drill bit drilled a hole in the sloped block $267 \mathrm{~mm}$ (10.5 in.) deep in 23 minutes. Used $18.9 \mathrm{~L}(5 \mathrm{gal})$ of cooling water. Anchored the pipe in the $25-\mathrm{mm}(1-i n$.$) hole with epoxy.$

- Core Barrel: Pipefitters brazed the diamond/matrix segment back onto the core barrel. Core drilled approximately $305 \mathrm{~mm}$ (12 in.) into the sloped grout layer and the cover block in 70 minutes. Used $94.6 \mathrm{~L}(25 \mathrm{gal})$ of cooling water. It took 30 minutes to finish drilling through the remaining $25 \mathrm{~mm}$ 
(1 in.) on the high side of the cover block and the $89 \mathrm{~mm}$ (3-1/2 in.) on the low side. Used 37.8-L (10-gal) of cooling water to finish. Difficult drilling was experienced at the end because the core drill bit was cutting into the $6.3-\mathrm{mm}(1 / 4-\mathrm{in}$.) steel bar holding the welded wire fabric. Two diamond/matrix segments moved on the core barrel due to cutting the metal bar in the absence of cooling water (see photo 18). The wedge-shaped circle of grout broke loose during core barrel drilling and spun inside the core barrel. The grout became wedged inside of the core barrel and broke the $15-\mathrm{mm}(1 / 2-\mathrm{in}$.) diameter retention pipe that had been attached to the core with epoxy. The epoxy anchor held. The retention pipe failed approximately $508 \mathrm{~mm}$ (20 in.) above the core plug.

- Riser: Polyurethane pipe insulation was used as a grout holding gasket for the lower end of the riser pipe. The pipe insulation used was $95 \mathrm{~mm}(3.75$ in.) wide and $13 \mathrm{~mm}$ $(1 / 2 \mathrm{in.}$ ) thick. The insulation material was wired and epoxy-cemented to the outside of the riser. With the riser set in the cover block and plumbed vertically, the initial grout addition over the gasket was $1.8 \mathrm{~L}(1 / 2 \mathrm{gal})$ of Masterflow 928 grout. The grout set for 30 minutes. Then, $22.7 \mathrm{~L}$ (6 gal) of Five Star epoxy was placed between the riser and the inner casing. No water leakage was detected through the grout after 3 days (see photos 23 and 24).

The hatch cover blocks and core plugs used in demonstrations $1,2,3$, and 4 were relocated to the ICF $\mathrm{KH}$ drilling equipment yard in the 200-East Area. 


\section{Demonstration 5: Simulated Riser Installation in Soil Column}

\section{Summary}

Demonstration 5 included all elements of Demonstrations 1 through 4 and addressed the installation of a riser in a simulated tank dome located under $3000 \mathrm{~mm}$ (10 ft) of compacted fill. A CMP pipe was placed vertically in the piping tunnel and filled with compacted construction fill to represent the fill over a tank dome. All excavation, drilling, and coring activities are to be done from the surface. Refer to Appendix I for the Demonstration 5 amended steps, the revised drawings, and the marked-up illustrations that recorded changes during the demonstration.

Date Started: December 4, 1995

Date Completed: January 4, 1996

\section{Results}

The following excavation activities, measurements, and observations were recorded in Demonstration 5.

- Corrugated Metal Pipe: Two hatch cover blocks were removed from the piping tunnel to allow access to the tunnel bottom. A mat of building paper, welded wire fabric, and grout was placed on the tunnel bottom to represent waterproofing material. A $3000 \mathrm{~m}$ (10 ft) length of $1220-\mathrm{mm}(48-\mathrm{in}$.) CMP was installed in a vertical position in the piping tunnel. The two hatch cover blocks that were removed to make room for the CMP were utilized during the preceding demonstrations.

The CMP was anchored to the tunnel bottom and top with metal brackets. Planks were placed to fill in the gaps in the tunnel roof. 
The CMP was filled with structural fill and compacted in 10 lifts to the soil density as shown in the data sheets in Appendix $A$ and in photo 11. Some soil density tests indicated over $100 \%$ compaction.

- Outer Casing: The outer casing was installed in a $9220-\mathrm{mm}$ (48-in.) CMP filled with compacted soil using a vacuum truck (Guzzler). To set the outer casing, the Guzzler was used to excavate a starter hole $508 \mathrm{~mm}(20 \mathrm{in}$.) deep and $600 \mathrm{~mm}$ (24 in.) in diameter which took 14 minutes (see photo 12). Then, a $1880-\mathrm{mm}$ (6-ft 2-in.) length of outer casing was set in the hole. The outer casing advanced another $1000 \mathrm{~mm}$ (3.28 ft) in the next. 60 minutes by the vacuum excavation method.

A $1500 \mathrm{~mm}$ (5 ft) length of outer casing was spliced onto the initial casing with a single-pass weld. The outer casing advanced another $600 \mathrm{~mm}(2 \mathrm{ft})$ in depth in approximately 1-1/2 hours. It became increasingly difficult to advance the outer casing as the depth increased. Continued vacuuming below the outer casing to the top of the grout covering the bottom of tunnel. The last $900 \mathrm{~mm}(3 \mathrm{ft})$ took 2 hours. Repeatedly lowered, about 15 times, a 1-T (2,200-lb) hatch cover block onto the outer casing to get it to advance the last $500 \mathrm{~mm}(2 \mathrm{ft}$ ) (see photo 13).

- Casing Shoe: An extension of $3800 \mathrm{~mm} \mathrm{(12} \mathrm{ft} 8 \mathrm{in}$.) of 450-mm (18-in.) pipe was added to the casing shoe in order for it to reach the tunnel bottom. Total weight of the drilling head, the 305-mm (12-in.) drive, the 450-mm (18-in.) pipe and the casing shoe was $0.9 \mathrm{~T}(2,100 \mathrm{lb})$. Drilled $178 \mathrm{~mm}(7 \mathrm{in}$. in 42 minutes and used $26.5 \mathrm{~L}(7 \mathrm{gal})$ of cooling water. The 
building paper and the 102-mm (4-in.) grout layer separated from tunnel bottom and was removed with the Guzzler (see photo 30).

- Grout: Used 49.2 L (13 gal) of Masterflow 928 between the inner and outer casing only. Grout was not allowed inside the inner casing. No leakage was detected during the water test.

- Setting Retention Pipe: Using the 25-mm (1-in.) drill bit, a hole was drilled $152 \mathrm{~mm}$ (6 in.) deep in 25 minutes. Used $26.5 \mathrm{~L}$ (7 gal) of cooling water inside the inner casing. All water and cuttings were vacuumed out, and the retention pipe was set with epoxy. Successfully pull tested the pipe at $3.1 \mathrm{kN}$ (700 lb) after the epoxy cured for 3 days.

- Core Barrel: Since several diamond/matrix segments had moved during previous demonstrations, all segments had extra brazed fillets placed on the inside of the core barrel. The fillets approximate size was $3 \mathrm{~mm}$ (1/8 in.).

Cored $279 \mathrm{~mm}(11$ in.) into the tunnel bottom in 55 minutes. Used $181.7 \mathrm{~L}$ (48 gal) of cooling water. The cooling water and drilling debris were vacuumed out. It was assumed that there was only $25 \mathrm{~mm}$ ( 1 in.) of drilling remaining, but the pipe tunnel base was $432 \mathrm{~mm}$ (17 in.) thick instead of $305 \mathrm{~mm}$ (12 in.) as shown on the drawings. Drilled the final $152 \mathrm{~mm}$ (6 in.) in 45 minutes, with only $18.9 \mathrm{~L}$ (5 gal) of cooling water used. Successfully removed the 432-mm (17-in.) thick core plug from the tunnel bottom (see photo 14).

- Risers: Used same gasket method as for Demonstration 4 (see photo 16 ). Set the polyurethane gasket on the outside of the 
riser and lowered the riser into the hole with the boom truck. Clips were welded between the top of the riser and the inner casing to maintain vertical alignment. Added $28.4 \mathrm{~L}$ ( $7.5 \mathrm{gal})$ of Masterflow 928 grout between plumbed riser and inner casing. The approximate depth of the grout was $343 \mathrm{~mm}$ (13.5 in.) between the riser and the cored hole, and $914 \mathrm{~mm}$ (36 in.) between the riser and the inner casing. No leakage was detected during the water test. Pulled vertically on the riser with $8.9 \mathrm{kN}(2,000 \mathrm{lb}) 24$ hours after the grout had set. No movement of the riser was detected (see photos 25, 26, 27 , and 28 ).

\section{CONCLUSIONS AND RECOMMENDATIONS}

\section{A. DEMONSTRATION RESULTS}

\section{Setting Outer Casing}

The volume of material excavated in setting the outer casing was minimal. By using the vacuum excavation method, less than $1.1 \mathrm{~m}^{3}$ $\left(1.5 \mathrm{yd}^{3}\right)$ was removed from the CMP for setting the outer casing. Very little excess soil was removed outside of the casing.

Contaminated soil can be confined easily in a vacuum truck or in other containers. The Guzzler has an optional loading device that can load open-top drums so the soil is kept outside of the truck holding tank. No airborne contamination is generated due to the multiple filter systems on the vacuum truck.

By use of the vacuum wand during excavation, existing underground utilities and obstacles can be located with little chance for damage to the utility or object. 
Approximately 6 hours were required to set a $3400 \mathrm{~mm}$ (11 ft $2 \mathrm{in}$.) length of 600-mm (24-in.) diameter outer casing. Time was included to weld one joint into the casing.

\section{Recommendations}

It is recommended that the outer casing be cut into short lengths of $1520 \mathrm{~mm}(5 \mathrm{ft}$ ) to $1829 \mathrm{~mm}(6 \mathrm{ft}$ ) so that the vacuum excavation can proceed while the casing is being placed. Excavate with the vacuum wand at least $610 \mathrm{~mm}$ ( 24 in.) into the soil before setting the bottom section of the casing. This allows a worker to handle the vacuum hose and wand while standing on the ground. No scaffolding is required.

Use a boom truck or a light crane to handle and plumb the casing.

Use a short length of $150-\mathrm{mm}$ (6-in.) diameter polyvinyl chloride (PVC) pipe on the lower section of the flexible vacuum hose to act as a wand. This allows for more rapid excavation and provides insulation against buried electrical cables. Ensure that all connections on the vacuum hose will not loosen during vigorous vacuuming.

When the outer casing hangs up as the depth increases, use a vibrator attached to the outer casing to advance the casing.

The outer casing is simply a guide path for the casing shoe and makes a form for the grout to seal the inner casing. Therefore, there is no need to grout the voids at the bottom or outside of the outer casing. 


\section{Setting Inner Casing}

Using a 450-mm (18-in.) casing shoe to cut a groove into a simulated concrete dome for grouting and setting a plain casing to form a seal for further drilling worked relatively well. Several diamond/matrix segments on the casing shoe moved so close attention must be paid to providing adequate addition of cooling water.

The averages for the preliminary test and the demonstrations are as follows:

- Drill Speed Range: 60 to $80 \mathrm{rpm}$.

- Depth Drill: $102 \mathrm{~mm}$ (4 in.).

- Drilling Time: 20 minutes.

- Casing Shoe Drilling Rate: Approximately $5 \mathrm{~mm} / \mathrm{min}$ (0.2 $\mathrm{in.} / \mathrm{min})$.

- $\quad$ Cooling Water Used: $30.2 \mathrm{~L}$ (8 gal) per demonstration.

- Diamond/Matrix Segments on the Casing Shoe Bit Wore Down: $0.6 \mathrm{~mm}(0.025 \mathrm{in.})$ or $7.5 \%$ of $8.5 \mathrm{~mm}(0.335 \mathrm{in.})$ total depth after $635 \mathrm{~mm}$ (25 in.) of drilling.

Nonshrink grout is necessary to ensure a good seal and to develop high early strength. Masterflow 928 is easier to use than Five Star epoxy and is less expensive. Grout placed between the inner and outer casing was effective to set and seal the inner plain casing. No water leakage occurred with the use of Masterflow 928 grout. 
Five of the 50 diamond/matrix segments moved on the casing shoe bit during Demonstration 5 after $635 \mathrm{~mm}$ (25 in.) of drilling. There was no indication of hang-up during drilling but the casing shoe appeared to get hot; however, it was never too hot to touch when it was brought up. Addition of cooling water is essential to the life of the casing shoe bit.

\section{Recommendations}

\section{- Drill String Weight}

The drill string could be lightened by using a shorter length of $450-\mathrm{mm}$ (18-in.) driver for the casing shoe or by using longer sections of the smaller $300-\mathrm{mm}$ (12-in.) driver. Even with a lighter drive, the total string weight could be as much as $0.68 \mathrm{~T}(1,500 \mathrm{lb})$. There is no need for heavy drilling pressure. A flexible drive head should be used, which allows for alignment adjustment of the drill bits.

\section{- Cooling Water}

The drilling water can be controlled by using a container, i.e., a 208-L (55-gal) drum, a small electric pump with a control valve, and a water meter with a flowrate indicator and totalizer (range from 0.25 to $5 \mathrm{gpm}$ ). Cooling water is introduced to the drill bits and core barrel through the hollow drill stem by a $15-\mathrm{mm}(1 / 2-$ in.) pipe. A small quantity of less than $76 \mathrm{~L}(20$ gal) of cooling water will dissipate under the outer casing, which is not sealed.

\section{- Retain Water-Proofing Material}

It is not necessary to remove the waterproofing, welded wire fabric, and gunite to get a good seal for the inner casing. For Demonstration 5, the casing shoe simply drilled through the 
waterproofing layers and into sound concrete. There was no water leakage between the inner and outer casing. Use Masterflow 928 or similar nonshrink grout for sealing the inner casing to the concrete dome.

\section{- Grout Between Casings}

Once the inner casing is set, fill the annular space with grout to the top of the outer casing. The inner and outer casing may need to be cut off to allow for placement of a concrete slab around the riser.

- Care of Drilling Toois

Ensure that two sets of the following critical drilling equipment are on hand to allow for repair and decontamination before the riser installation activity begins.

- 25-mm (1-in.) drill bit

- 368-mm (14.5-in.) core barrel

- 450-mm (18-in.) casing shoe

Minimize drilling pressure on the 450-mm (18-in.) casing shoe and core barrel during drilling by holding the drill string with the drill rig hydraulic pressure system. Check the shoe and core barrel for loose or worn diamond/matrix segments after each use.

Obtain written specifications for operations and repairs of the casing shoe and core barrel from the vendor. Determine under what conditions the diamond/matrix segments may loosen and move. Braze the segments with extra weld to stop movement. Prepare for adequate cooling water addition and disposal. 


\section{Setting Retention Device}

Originally, a double-walled core barrel with a core lifter spring was specified to ensure that the core would be retained within the core barrel, but Christensen Mining Products (the core barrel vendor) was concerned that cutting through several layers of rebar with the relatively large (368-mm [14.5-in.]) core barrel might destroy the core lifter (Letter, Hawkes [Christensen Mining Products) to P.L. Harvey IICF KH], September 23, 1994.)

\section{Retention Rod and Pipe}

As an alternative to a core lifter, the Activity Plan called for a $19-\mathrm{mm}$ (3/4-in.) diameter rod, epoxy grouted into a $25-\mathrm{mm}$ ( 1 -in.) hole at the center of the core. The rod extended up through the hollow drill stem and attached to the drill hoist to be used to retain the core. The rod was pull tested during the preliminary test and it held fast to the grout plug.

During the demonstration, ICF KH drillers proposed using a 15-mm (1/2-in.) pipe that could retain the core and also act as a conduit for the cooling water. A $15-\mathrm{mm}(1 / 2-\mathrm{in}$.) diameter galvanized pipe was set and successfully pull tested in Demonstrations 3 and 5 isee photos 14 and 29.

- The averages for the four demonstrations are as follows:

- Drill Rate Range for a 25-mm (1-in.) Diameter Hole: $6 \mathrm{~mm}(1 / 4 \mathrm{in}$.$) per minute.$

- Drill Speed: 130 to $150 \mathrm{rpm}$.

- Cooling Water: $18.9 \mathrm{~L}$ (5 gal). 
Water intermittently was run through the drill stem, but more pressure was needed to force the cooling water through the orifice in the drill bit than the gravity head provided. A pressurized cooling water system is essential for the operation of the small drill bit.

- Pull tested $3.1 \mathrm{kN}(700 \mathrm{lb})$ and $4.2 \mathrm{kN}(950 \mathrm{lb})$ on the rod and the pipe for two successful tests after the epoxy had set.

- The epoxy tubes that were dropped into the center hole were crushed and mixed well with vigorous rotating and hammering on the pipe. This allowed the epoxy resin compounds to mix well and form a strong bond.

- The pipe end was closed and pointed. Dimples that were welded on the outside of the pipe helped bond the pipe to the epoxy. A series of 6-mm (1/4-in.) holes were drilled into the pipe to provide water flow into the core barrel.

\section{Recommendations}

- Approximately $18.9 \mathrm{~L}$ (5 gal) of cooling water in the sealed inner casing is enough to cool the small bit and dilute the cuttings.

Pressurized recirculation water at $68.9 \mathrm{kPa}(10 \mathrm{psi})$ and a flow of 3.8 to $7.6 \mathrm{~L} / \mathrm{min}$ ( 1 to $2 \mathrm{gal} / \mathrm{min}$ ) will help in the small drill bit performance.

- The hole should be drilled at least $127 \mathrm{~mm}(5 \mathrm{in}$.) into sound concrete. Clean out the water and cuttings and dry the hole as much as possible before setting the retention pipe. 
- Close the end of the pipe, dimple with weld for good epoxy bonding, and drill holes for the cooling water. Use Schedule 40 pipe and light couplings. Verify that the couplings fit through the drill stem prior to use. Use at least one epoxy capsule (19 $\mathrm{mm}$ by $166 \mathrm{~mm} \mathrm{[3/4} \mathrm{in.} \mathrm{by} \mathrm{6-5/8} \mathrm{in.])} \mathrm{(Hilti} \mathrm{part}$ $000668129)$ per hole. Break the capsule, rotate the pipe vigorously for 2 to 3 minutes, hammer on the pipe, and tie the pipe in place to allow epoxy to cure. Do not disturb for several hours. Pull test the pipe to at least twice the expected weight of the concrete core plug, the core barrel weight, and the weight of the drill string.

\section{Core Barrel Performance}

The core barrel worked well except when the diamond/matrix segment on the core barrel bit either moved or, in one case, came off the core barrel. Brazing the diamond/matrix segment onto the core barrel was partially successful.

- The averages for the four demonstrations are as follows:

- Drill Rate Range: $5.0 \mathrm{~mm}(0.2 \mathrm{in.})$ per minute

- Drill Speed: 80 to $100 \mathrm{rpm}$.

- Cooling Water: 76 to $189 \mathrm{~L}$ (29 to $50 \mathrm{gal}$ ).

- Diamond/Matrix Segments Wore Down: $0.36 \mathrm{~mm}$ (0.014 in.) out of an average total depth of $7.7 \mathrm{~mm}$ (0.304 in.), or $4-1 / 2 \%$, after $1900 \mathrm{~mm}$ (75 in.) of drilling. 
- As many as 6 out of 30 diamond/matrix segments on the core barrel moved even after extra brazing was added to the inside of all cover blocks (see photo 18).

- A mild steel subadapter for connecting the drill rod to the core barrel, furnished by Christensen Mining Products, belled out at the top during the drilling activities. In demonstration 1, a copper wire gasket was used to help distribute the pressure on the adapter. The condition of the adapter did not worsen during the remainder of the demonstrations.

\section{Recommendations}

- Obtain a hardened subadapter fitting to connect the drill stem to the core barrel and ensure that the connection is torqued to the specifications.

- Have a spare core barrel if repair or decontamination is required.

- Mount a centralizer as close as possible above the core barrel to ensure that it is centered within the inner casing. During Demonstration 5 , a centralizer mounted more than $1829 \mathrm{~mm}$ $(6 \mathrm{ft})$ above the core barrel allowed the core to drift off center $51 \mathrm{~mm}(2 \mathrm{in}$.) with respect to the inner casing.

- See comments for casing shoe regarding how to ensure that the diamond/matrix segments do not move.

\section{Installation Riser}

Installing risers in the hole cored in the concrete is the final step in the riser installation sequence. A 324-mm (12.75-in.) outer diameter riser installed inside a $368-\mathrm{mm}$ (14-1/2 in.) diameter cored hole 
allows a gap of $22 \mathrm{~mm}(7 / 8 \mathrm{in.})$. This gap is sufficient to allow grout to form an effective seal and to bond between the riser and the cored hole. The gap provides clearance to plumb the riser vertically before it is set in place with grout.

- Demonstrations 4 and 5 included installation of a $300-\mathrm{mm}$ (12-in.) riser and both demonstrations utilized the polyurethane pipe insulation as a gasket to seal between the riser and the core hole. The only function of this gasket seal is to form a temporary closure so grout cannot leak through while the grout is allowed to set. The relatively soft, flexible material can conform to the core hole and can be squeezed to allow the riser to be plumbed.

- Results of both demonstrations showed no leakage through the grout after it cured. Demonstration 5 included an $8.9-\mathrm{kN}$ $(2,000-\mathrm{lb})$ vertical pull on the riser to test the seal between the riser and core hole, and the riser and the inner casing. No movement was noted.

\section{Recommendations}

- After the outer casing is set and the outside of the tank dome is exposed, measure down to the dome to determine the length of the riser. An estimate of the dome thickness taken from the construction drawings will provide the location of the gasket for the bottom grout seal. These measurements will allow verification that the new riser is fabricated to the correct length.

- Flat polyurethane sheeting could be used in lieu of pipe insulation for the gasket material. Attach the sheeting to the riser pipe with plastic ties and rubber cement. Further testing 
is required to weigh the advantages of the two methods of providing a grout seal.

- A pair of steel collars could be welded near the bottom of the prefabricated riser to keep the polyurethane gaskets from moving or from dropping into the tank upon deterioration.

- Once the riser is plumb, place enough grout to fill the void between the riser and the cored hole and put at least $152 \mathrm{~mm}$ (6 in.) of grout between the riser and the inner casing. Let the grout cure to the manufacturer's requirements. Check to see if the grout is filled to the top of the inner casing.

- Construct a slab of concrete at grade around the riser installation. The slab provides a water seal, a work platform, and a base for future equipment installation in the riser.

\section{B. ALARA}

Contaminated soils may be encountered during excavation of the outer casing with the Guzzler. If contaminated soil is encountered, vacuuming techniques must be modified to distance the workman from the vacuum hose to lower the radiation exposure time. Inspection of the hole with high intensity lights and mirrors can be conducted to lessen exposure. Depending upon the contamination level of the soil and radiation exposure to the workers, the soil could be collected either in the truck-mounted vacuum tank or in 55-gal drums. Either method would provide some shielding.

The outer casing would provide shielding from contaminated soil but not shielding from the tank dome. If contamination is present on the dome, the casing shoe may have to be either decontaminated or grouted to the dome after drilling. 
For the small $25-\mathrm{mm}$ (1-in.) drill for setting the retention pipe, the drilling water can be confined to the inside of the inner casing and vacuumed out after drilling is complete. The drill may need to be decontaminated.

Drilling with a core barrel until it breaks through the tank dome should result in minimal radiation exposure. When the core is completely free and being withdrawn, a $368-\mathrm{mm}$ (14.5-in.) hole will be open into the tank. The bottom of the core being withdrawn is potentially contaminated. These operations must be planned carefully to minimize exposure. Once the core is withdrawn, temporary shielding can be placed over the casing. Insertion of the prefabricated riser with a gasket seal can be done relatively quickly (estimated within 10 minutes) to minimize exposure time. Grouting can begin immediately after the riser has been plumbed. The $300-\mathrm{mm}$ (12-in.) riser will include a blind flange or shielding plug at the top end.

\section{DRILLING CONTRACTOR}

Setting risers in SSTs does not require production drilling equipment or deep-drilling techniques. The time required for set-up, job safety analysis, ALARA requirements, work procedures, and demobilization from the tank farm can change the scope of work significantly. If contaminated soils or underground utilities are encountered while excavating for setting the outer casing, the riser location may need to be changed, which would alter the work scope. Drillers experienced in tank farm drilling and with specific knowledge of techniques and equipment used in the riser simulation test should be utilized for this specialized drilling task.

\section{INSTALLATION OF LARGER RISERS}

The riser simulation test proved that existing techniques and equipment can be used to readily install a 300-mm (12-in.) riser in SSTs. Utilizing the same techniques and making modifications to equipment may allow 
installation of larger risers. To determine the practical size limit, the following would have to be resolved:

- What is the largest outer casing that could be set with a light crane and vacuum truck? Weight of the casing and skin friction will limit maximum size.

- What is the largest casing shoe and core barrel that could drill into the concrete dome? This is limited by the drill rig capacity, the weight of the drill string, and the ability to drive the casing shoe or core barrel assembly.

- What is the effect on the geometry of a large-sized drill bit on the slope of the dome? Also, what effect does the increased weight of a larger core have on the ability to restain it from falling into the tank?

- More reinforcing bars will be cut in the dome for a larger riser which could effect the structural integrity of the dome.

\section{E. DOME LOADING}

Each major piece of drilling equipment, i.e., the vacuum truck (Guzzler), drill rig, and boom truck (light crane), can weigh in excess of $13.6 \mathrm{~T}$ (15 tons). Only the drill rig needs to be directly adjacent to the location of the new riser. The other equipment can be spaced at some distance from the drill site to reduce loads on the tank dome.

Drilling with a casing shoe to set the inner casing could result in cutting several reinforcing bars on the top mat of the reinforcing steel. Drilling through the dome with the core barrel will cut a number of reinforcing bars in both the top and bottom mat which is a more severe condition that must be checked as to loads from major pieces of equipment. Drill 
pressures can be light for both the casing shoe and the core barrel so the drilling pressures should not affect the dome loading significantly.

\section{F. COST INFORMATION}

From updated cost information and the experience gained in the simulated riser installation field test activities, the cost to install a new riser is estimated to be $\$ 1,305,000$. After the first riser is installed, the estimated cost to install each additional riser will be $\$ 250,000$. The cost information for each additional riser includes $\$ 30,000$ for permitting, environmental assessment, and safety analysis. Cost information details are shown in Appendix $E$.

\section{G. SCHEDULE}

The riser installation in an actual SST is scheduled to take approximately $10-1 / 2$ months of planning, permitting, and engineering and 1-1/2 months to install. The total time required for the riser installation process is 1 year. Schedule information is shown in Appendix $F$.

\section{REFERENCES}

1. Engineering Study, "Installation of New Risers in Single-Shell Tanks," prepared by ICF Kaiser Hanford Company, Document No. WHC-SD-WM-ER-299, Rev. O, dated August 1994.

2. Activity Plan, "Simulated Riser Installation by Use of Rotary Drilling," prepared by ICF Kaiser Hanford Company, Document No. WHC-SD-WM-AP-034, Rev. 1, dated December 1995.

3. Geotechnical Report, "Evaluation of Sampling Tools and Activities Used for Characterization of the Hanford Single-Shell High-Level Tank Wastes," prepared by U.S. Army Corps of Engineers, February 1995. 


\title{
APPENDIX A
}

\author{
Data Sheets
}




\section{SIMULATED RISER TEST DATA SHEETS}

The data sheets for recording the riser simulation field tests were extracted from the Activity Plan, "Simulated Riser Installation by Use of Rotary Drilling," Document No. WHC-SD-WM-AP-034, Rev. 0, dated December 1995. The data sheets were completed during each simulated riser test by the ICF KH test engineer. The soil compaction tests and grout hardness tests were taken by ICF KH Quality Assurance and the results were provided by Shannon \& Wilson, Inc.

\begin{tabular}{|c|c|c|}
\hline Test & \multicolumn{1}{|c|}{ Date } & Objective \\
\hline Preliminary & $12 / 05 / 95$ to $12 / 12 / 95$ & Trial drilling activities \\
\hline 1 & $12 / 12 / 95$ to $12 / 13 / 95$ & Set inner casing \\
\hline 2 & $12 / 15 / 95$ to $12 / 19 / 95$ & Set inner casing, center pipe, and core drill \\
\hline 3 & $12 / 14 / 95$ to $01 / 03 / 96$ & Set inner casing, center pipe, and core drill \\
\hline 4 & $12 / 20 / 95$ to $12 / 28 / 95$ & $\begin{array}{l}\text { Set inner casing, center pipe, core drill, set } \\
\text { riser on slope }\end{array}$ \\
\hline 5 & $12 / 04 / 95$ to $01 / 04 / 96$ & Simulated riser test \\
\hline
\end{tabular}


RISER SIMULATION TEST TEST PREPARATION DATA SHEET

\section{ORIGNAL}

\begin{tabular}{|c|c|c|c|c|c|}
\hline \multicolumn{6}{|c|}{ TEST NUMBER: } \\
\hline \multirow{2}{*}{\multicolumn{2}{|c|}{ Component. }} & \multicolumn{4}{|c|}{ DESCRIPTION } \\
\hline & & \multicolumn{2}{|r|}{ Size } & Specification & Initial/Date \\
\hline \multicolumn{2}{|c|}{$\begin{array}{l}\text { Component } \\
\text { Outer Casing }\end{array}$} & \multicolumn{2}{|c|}{$24^{\prime \prime} \phi x-5 \times 2-0$} & $A 106-B$ & RLA $12 / 6 / 95$ \\
\hline \multicolumn{2}{|l|}{ Inner Casing } & \multicolumn{2}{|c|}{$18^{11} \phi x^{3} 8 \times 2^{1}-6$} & 5 & 5 \\
\hline \multicolumn{2}{|l|}{ Riser } & \multicolumn{2}{|c|}{$\mathrm{N} / \mathrm{A}$} & & $\sum$ \\
\hline \multicolumn{2}{|l|}{ Riser Flange } & \multicolumn{2}{|c|}{5} & & \\
\hline \multicolumn{2}{|c|}{ Core Retaining Rod. } & \multicolumn{2}{|c|}{$3 / 4^{\prime \prime} \phi x \sim 18^{\prime \prime}$} & $A-3 \varphi$ & \\
\hline \multicolumn{2}{|c|}{ Epoxy Adhesive } & \multicolumn{2}{|c|}{$3_{4}^{11} 9 \times 60^{5} 8$} & (H)LAM 14 EA & \} \\
\hline \multicolumn{2}{|c|}{ Equipment/Supplies } & \multicolumn{2}{|c|}{ Description } & \begin{tabular}{|l|} 
Supplier \\
\end{tabular} & Initial/Date \\
\hline \multicolumn{2}{|c|}{ Rotary Drill } & \multicolumn{2}{|c|}{$B-61 N D$} & MOSIL DRIL & $124+12 / 5 / 95$ \\
\hline \multicolumn{2}{|l|}{ Casing Shoe } & \multicolumn{2}{|c|}{$18 \frac{1}{500-\sin a u b}$} & CURISTENLSIEN & $C$ \\
\hline \multicolumn{2}{|l|}{ Core Barrel } & \multicolumn{2}{|c|}{$14 \frac{1}{2}$ OD - AAMOUD } & ClNRISTEMSEN & \\
\hline \multicolumn{2}{|l|}{ Grout } & \multicolumn{2}{|c|}{ MASTERFNOW 928 } & MASTER - BulloER & \{ \\
\hline \multicolumn{2}{|l|}{ Guzzler } & \multicolumn{2}{|c|}{ TRUCK mountao } & GUZZLER MaR UF. & 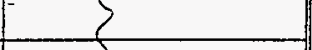 \\
\hline \multicolumn{2}{|c|}{ Other-BOOM TRUCK } & \multicolumn{2}{|c|}{ NATOMAC SEOES } & Fone F- 800 Truad & 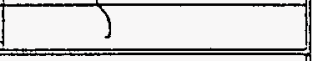 \\
\hline $\begin{array}{l}\text { Dimension } \\
\text { (Incties) }\end{array}$ & $W$ & $L$ & Depth & Initial/Date & Remarks \\
\hline $\begin{array}{l}\text { Casing Shoe } \\
\text { Blocks } \\
1\end{array}$ & .535 & .800 & .362 & RLA $175 / 95^{\circ}$ & AS RECIAUED \\
\hline 2 & .545 & .800 & .556 & $C$ & Foom VEUbok \\
\hline 3 & .544 & .789 & 355 & $\sum$ & 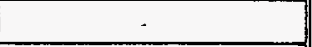 \\
\hline 4 & .530 & 792 & .357 & & \\
\hline $\begin{array}{l}\text { Core Barrel } \\
\text { Blocks } \\
1\end{array}$ & .528 & .850 & .332 & $12 / 5 / 95$ & As $E E C \theta U \theta \Delta$ \\
\hline 2 & 504 & .795 & 330 & s & Floon veupoe \\
\hline 3 & .50 .6 & .798 & .318 & 2 & $C$ \\
\hline 4 & .505 & .792 & 316 & 5 & $?$ \\
\hline
\end{tabular}

Rev. 2, 11/29/95 cab 


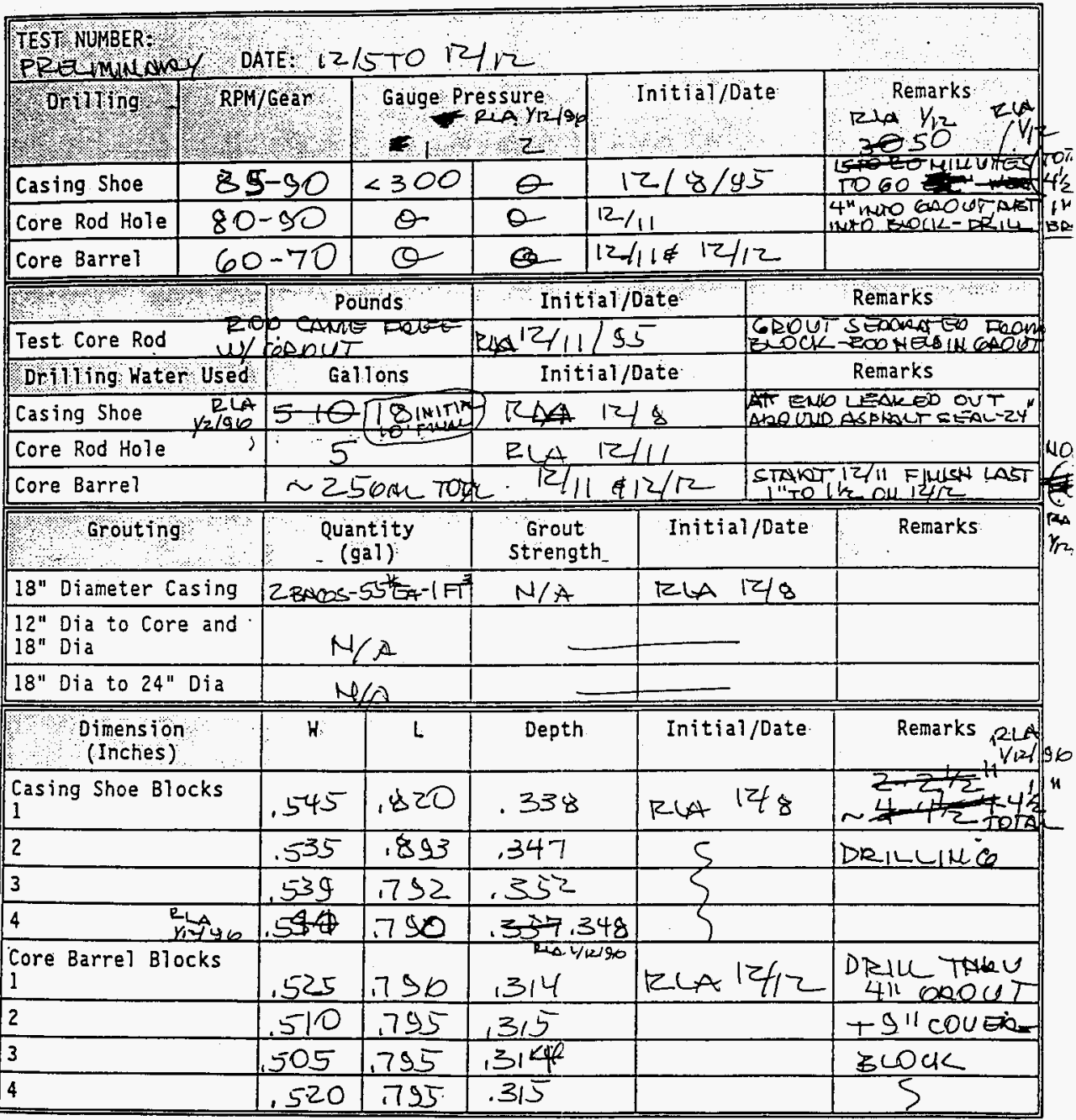

Rev. 2, 11/29/95 cab 


\section{RISER SIMULATION TEST \\ TEST ACTIVITY DATA SHEET (Sh 2 of 2)}

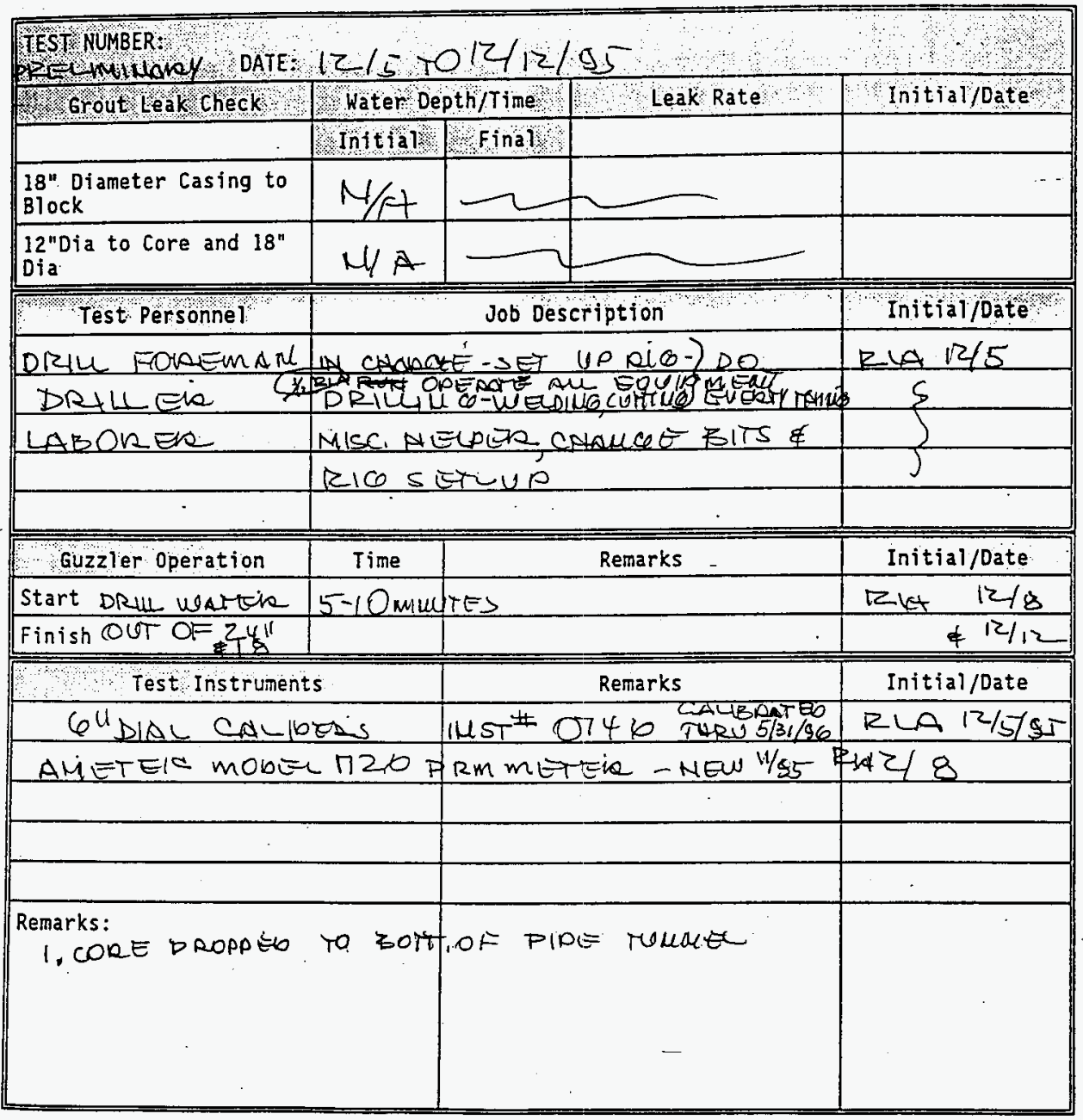

Rev. 2, 11/29/95 cab 


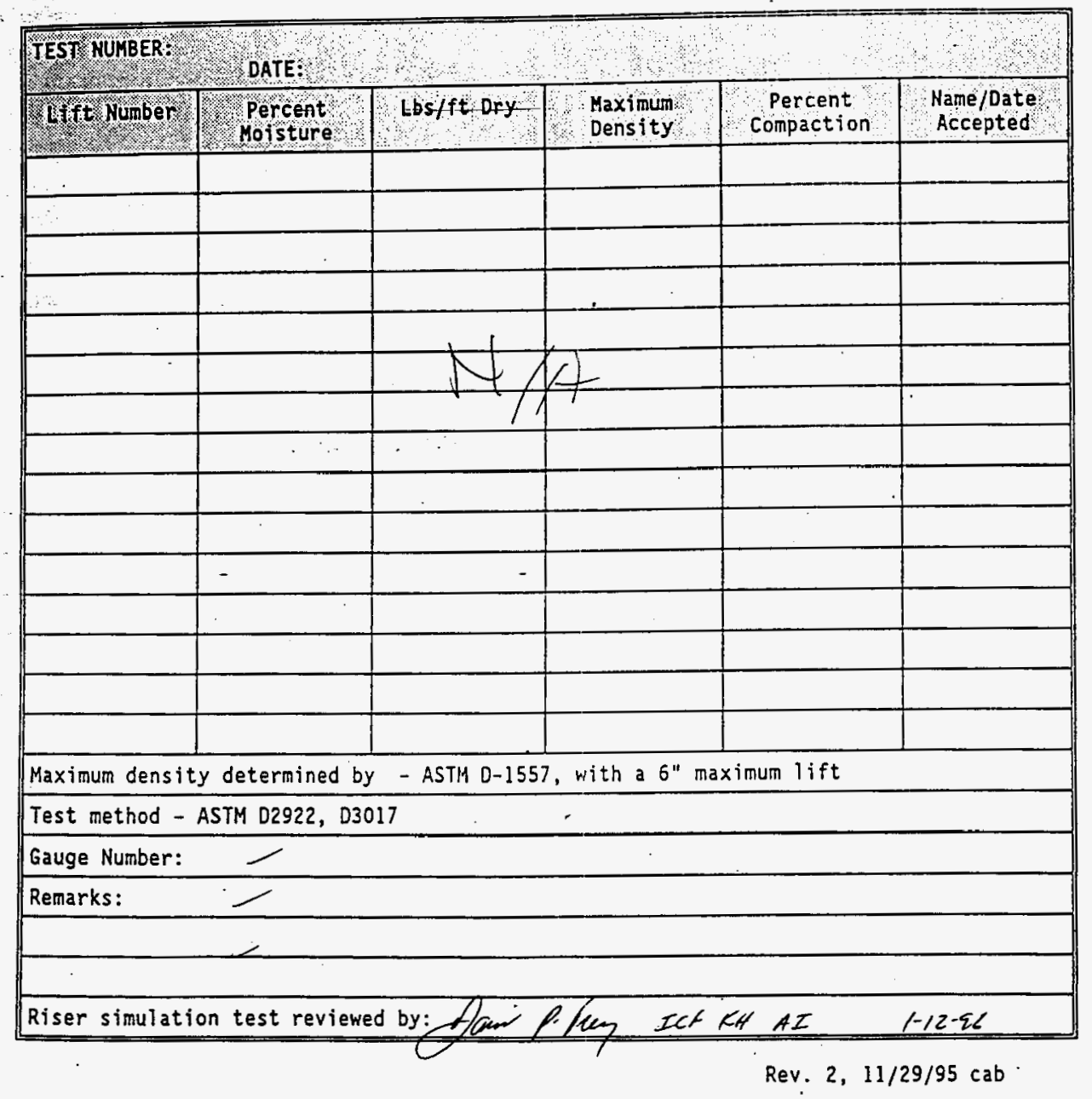




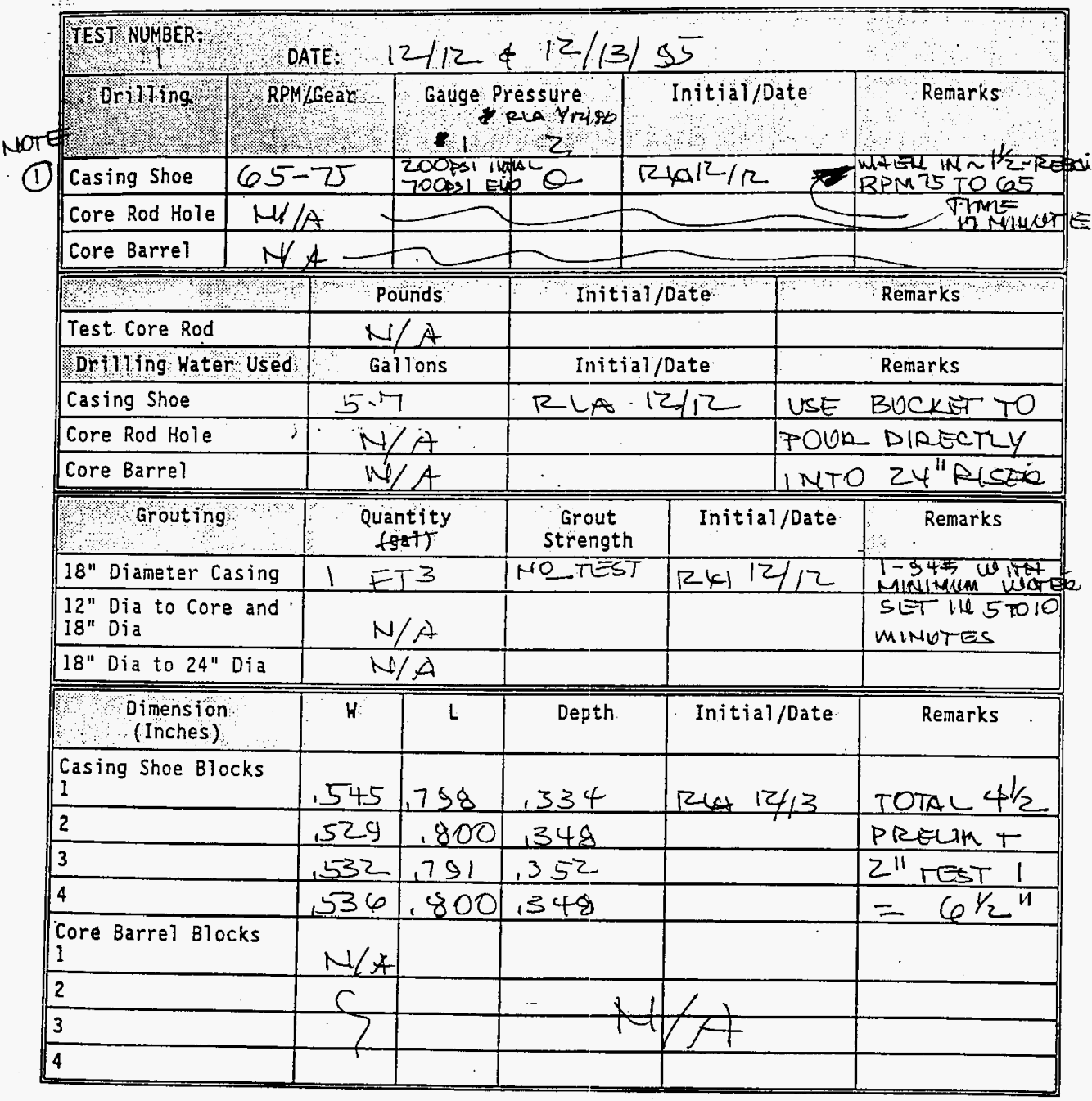

Rev. 2, 11/29/95 cab 


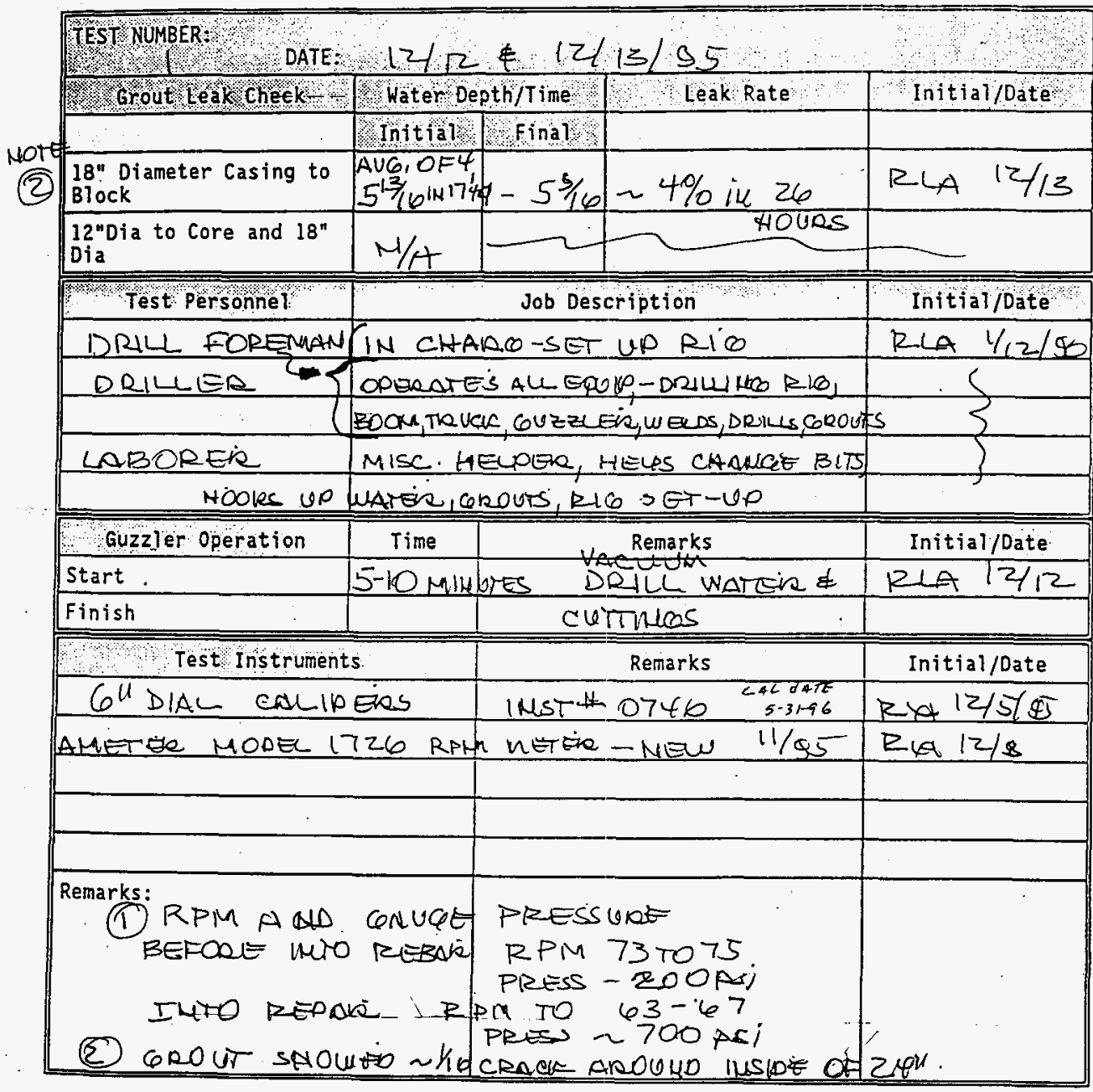

Rev. 2, $11 / 29 / 95$ cab 


\section{RISER SIMULATION TEST TEST PREPARATION DATA SHEET}

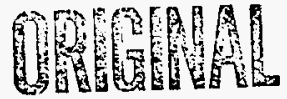

\begin{tabular}{|c|c|c|c|c|c|}
\hline \multirow{2}{*}{\multicolumn{2}{|c|}{ TEST NUMBER: }} & \multicolumn{4}{|c|}{ - SE lUHER CASULCo } \\
\hline & & \multicolumn{4}{|c|}{ DESCRIPTION } \\
\hline \multicolumn{2}{|l|}{ Component } & \multicolumn{2}{|r|}{ Size: } & Specification & Initial/Date. \\
\hline \multicolumn{2}{|l|}{ Outer Casing } & \multicolumn{2}{|c|}{$24^{\prime \prime} 0 x^{3} 4$ wan $\times 2^{\prime}-9$} & $A 106-B$ & RLA $2 / 2$ \\
\hline \multicolumn{2}{|l|}{ Inner Casing } & \multicolumn{2}{|c|}{$189 \times 38 \times 24$} & $\Delta 106-B$ & $c$ \\
\hline \multicolumn{2}{|l|}{ Riser } & \multicolumn{2}{|c|}{$N / A$} & & $\sum$ \\
\hline \multicolumn{2}{|l|}{ Riser Flange } & \multicolumn{2}{|c|}{$N / A$} & & ) \\
\hline \multicolumn{2}{|c|}{ Core Retaining Rod. } & \multicolumn{2}{|c|}{$\mathrm{H} / \mathrm{A}$} & & J \\
\hline \multicolumn{2}{|c|}{ Epoxy Adhesive } & \multicolumn{2}{|c|}{$N / A$} & & \\
\hline \multicolumn{2}{|c|}{ Equipment/Suppli ies } & \multicolumn{2}{|c|}{ Description } & Suppl jer & Initial/Date \\
\hline \multicolumn{2}{|c|}{ Rotary Drill } & \multicolumn{2}{|c|}{$B-61+D$} & MOBIL DRILL & R/9 $13 / 2$ \\
\hline \multicolumn{2}{|l|}{ Casing Shoe } & \multicolumn{2}{|c|}{ Is \& OD - DISAMONO } & CAR ISTCANSEC & \\
\hline \multicolumn{2}{|l|}{ Core Barrel } & \multicolumn{2}{|c|}{$N / A$} & & 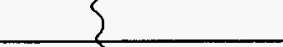 \\
\hline \multicolumn{2}{|l|}{ Grout } & \multicolumn{2}{|c|}{ TKPE I\& II } & ASH GROVE & 2 \\
\hline \multicolumn{2}{|l|}{ Guzzler. } & \multicolumn{2}{|c|}{ TRUCA MOUNTEO } & GUZZLEK MAKUF & $?$ \\
\hline \multicolumn{2}{|c|}{ Other BOOMn TheUCK } & \multicolumn{2}{|c|}{$\begin{array}{l}\text { Norloun } \\
\text { SEDES } 400 A \text { OM }\end{array}$} & EORAF-800 TRUMC & 3 \\
\hline $\begin{array}{c}\text { Dimension } \\
\text { (Inches) }\end{array}$ & $W$ & 1 & Depth & Initial/Date & Remarks \\
\hline $\begin{array}{l}\text { Casing Shoe } \\
\text { Blocks } \\
1\end{array}$ & .545 & .820 & 1338 & RLA $12 / 8$ & DIMS. FROM \\
\hline 2 & .35 & 893 & 347 & $S$ & PREL MIMANY \\
\hline 3 & 539 & 1792 & 352 & 5 & $T E S T$ \\
\hline 4 & 544 & .790 & 348 & 7 & \\
\hline $\begin{array}{l}\text { Core Barrel } \\
\text { Blocks } \\
1\end{array}$ & & & & & \\
\hline $2 \infty$ & & T1 & & & \\
\hline 3 & & & $\Delta$ & & \\
\hline 4 & & & & & \\
\hline
\end{tabular}

Rev. 2, 11/29/95 cab 


\section{RISER SIMULATION TEST} SOIL DENSITY DATA SHEET
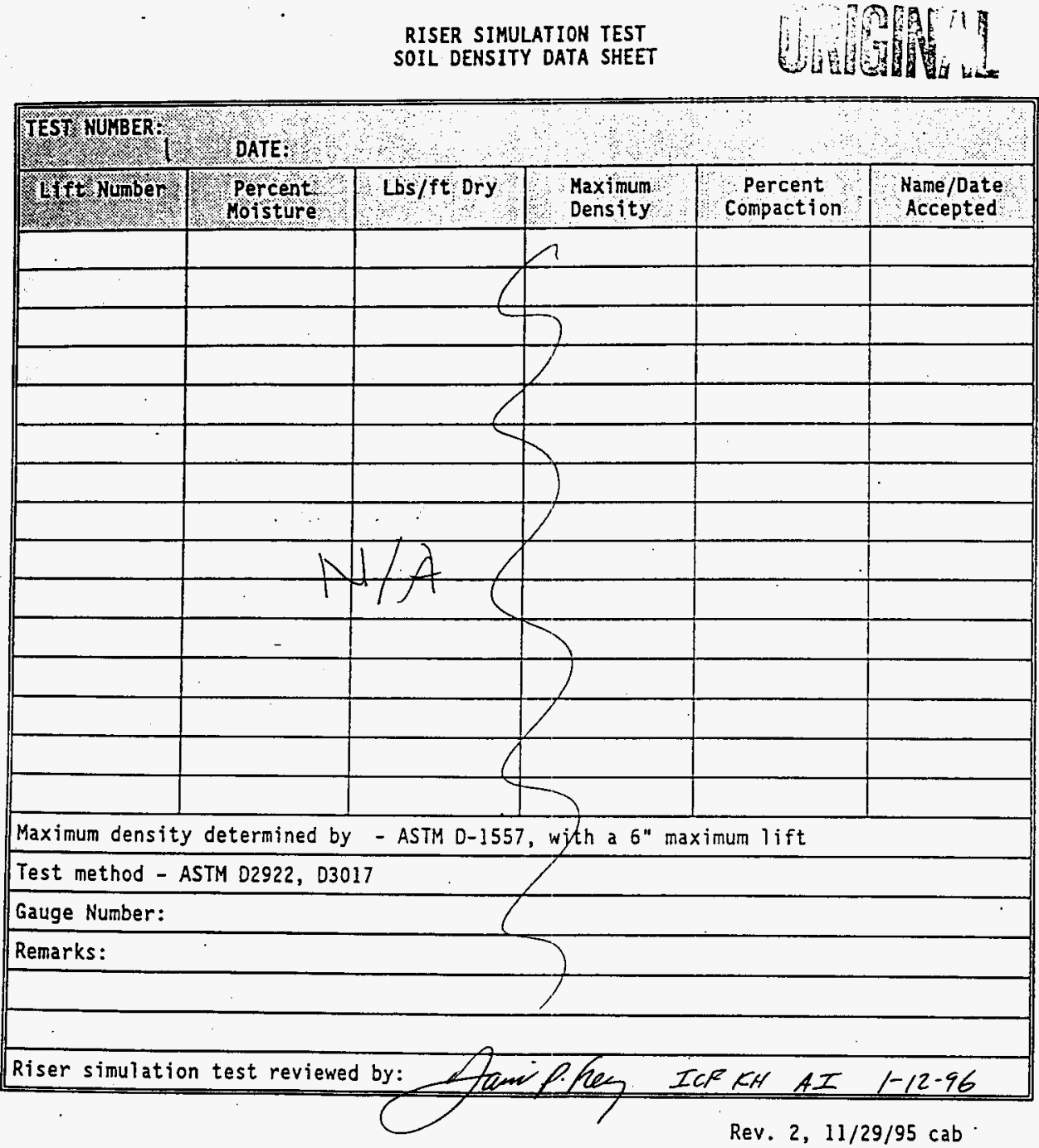


\section{RISER SIMULATION TEST TEST PREPARATION DATA SHEET}

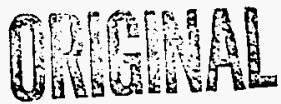

\begin{tabular}{|c|c|c|c|c|c|}
\hline \multirow{2}{*}{\multicolumn{2}{|c|}{ TEST NUMBER: 2 DATE: }} & \multicolumn{4}{|c|}{$\begin{array}{l}\text { SET HUMEA CARIUO,OEUTER } \\
\text { S PIPE AUD CORE DRIU }\end{array}$} \\
\hline & & \multicolumn{4}{|c|}{ DESCRIPTION } \\
\hline \multicolumn{2}{|c|}{ Component } & \multicolumn{2}{|r|}{ Size } & Specification & Initial/Date \\
\hline \multicolumn{2}{|c|}{ Outer Casing } & \multicolumn{2}{|c|}{$24^{\prime \prime} \Phi \times 3 \times 2^{2}-0$} & At $106-B$ & $2, A 12 / 0$ \\
\hline \multicolumn{2}{|l|}{ Inner Casing } & \multicolumn{2}{|c|}{$18^{11} 9 \times 30 \times 2^{2} 4$} & $14106-B$ & $\zeta$ \\
\hline \multicolumn{2}{|l|}{ Riser } & \multicolumn{2}{|c|}{$N / A$} & & \\
\hline \multicolumn{2}{|c|}{ Riser Flange } & \multicolumn{2}{|c|}{$\mathrm{N} / \mathrm{A}$} & & \\
\hline \multicolumn{2}{|c|}{ Core Retaining } & \multicolumn{2}{|c|}{$1 / 2 " P$ PIPE $5 C 40$} & $A-53$ & R6 1215 \\
\hline \multicolumn{2}{|c|}{ Epoxy Adhesive } & \multicolumn{2}{|c|}{$3 / 4^{\prime} \$ \times 67^{58}$} & $\begin{array}{l}\text { HILT \# } \\
\text { PART OOO6608129 }\end{array}$ & $\sum$ \\
\hline \multicolumn{2}{|c|}{ Equipment/Suppities } & \multicolumn{2}{|c|}{ Description } & Supplier & Iniţial/Date \\
\hline \multicolumn{2}{|c|}{ Rotary Drill } & \multicolumn{2}{|c|}{$B-61 \% D$} & NIOBIL DRILL & $R$ La $12 / 15$ \\
\hline \multicolumn{2}{|l|}{ Casing Shoe } & \multicolumn{2}{|c|}{$18 / 800-D 14 m 0$ inb } & CARISTEMSEN & \\
\hline \multicolumn{2}{|l|}{ Core Barrel } & \multicolumn{2}{|c|}{$14 \mathrm{~K}$ oD-D lamound } & CARISTENSEM & 2 \\
\hline \multicolumn{2}{|l|}{ Grout } & \multicolumn{3}{|c|}{92 -8-WASTEOFUWMASTEK BULDO } & \\
\hline \multicolumn{2}{|c|}{ Guzzler. } & \multicolumn{2}{|c|}{ TRuCk HOU HTEO } & GUZZLER & \\
\hline \multicolumn{2}{|c|}{ 0ther-soom The var } & \multicolumn{3}{|c|}{ NATOUNL SERES } & \\
\hline $\begin{array}{l}\text { Difmension } \\
\text { (Incties) }\end{array}$ & $H:$ & $L$ & Depth & Initial/Date & Remarks \\
\hline $\begin{array}{l}\text { Casing Shoe } \\
\text { Blocks } \\
1\end{array}$ & .542 & .803 & 1340 & RLA 1215 & STANE TOFAL \\
\hline 2 & 1562 & .795 & .358 & 5 & $12 y_{2}$ "DRUIED \\
\hline 3 & 536 & .755 &, 351 & 4 & TO DATE \\
\hline 4 & .553 & .790 & .348 & 7 & \\
\hline $\begin{array}{l}\text { Core Barrel } \\
\text { Blocks } \\
1\end{array}$ & .525 & .796 & .314 & $2612 / 12$ & QSTak' TOTRL \\
\hline 2 & .510 & .755 & .315 & $C_{2}$ & DRILEED 13"1- \\
\hline 3 & .505 & .755 & 1314 & $\zeta$ & PRELIA TEST. \\
\hline 4 & .520 & .755 & 1315 & ) & \\
\hline
\end{tabular}

Rev. 2, 11/29/95 cab 


\section{RISER SIMULATION TEST \\ TEST ACTIVITY DATA SHEET (Sh 1 of 2) \\ ESb}

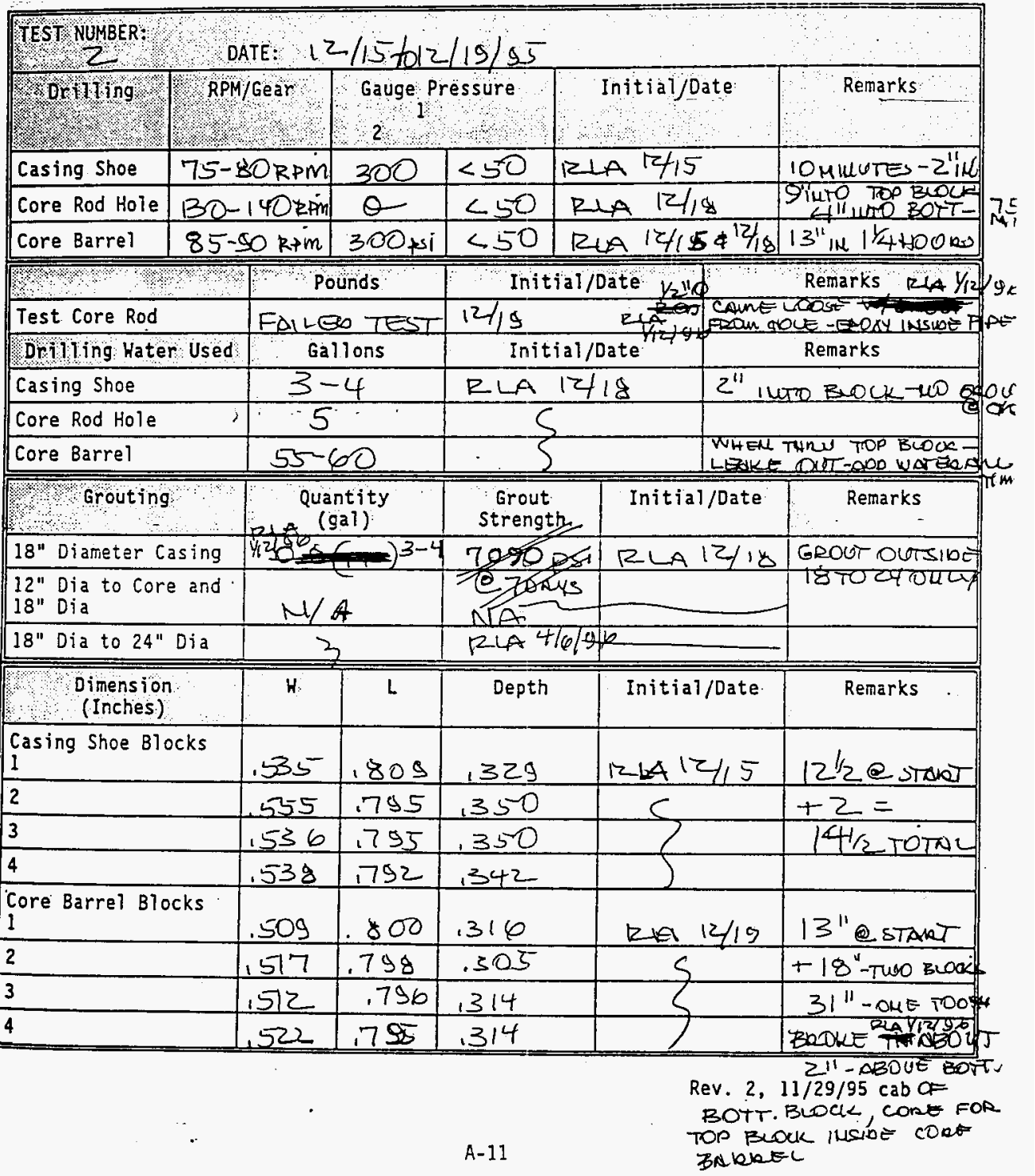




\section{RISER SIMULATION TEST \\ TEST ACTIVITY DATA SHEET (Sh 2 of 2)}

6rom

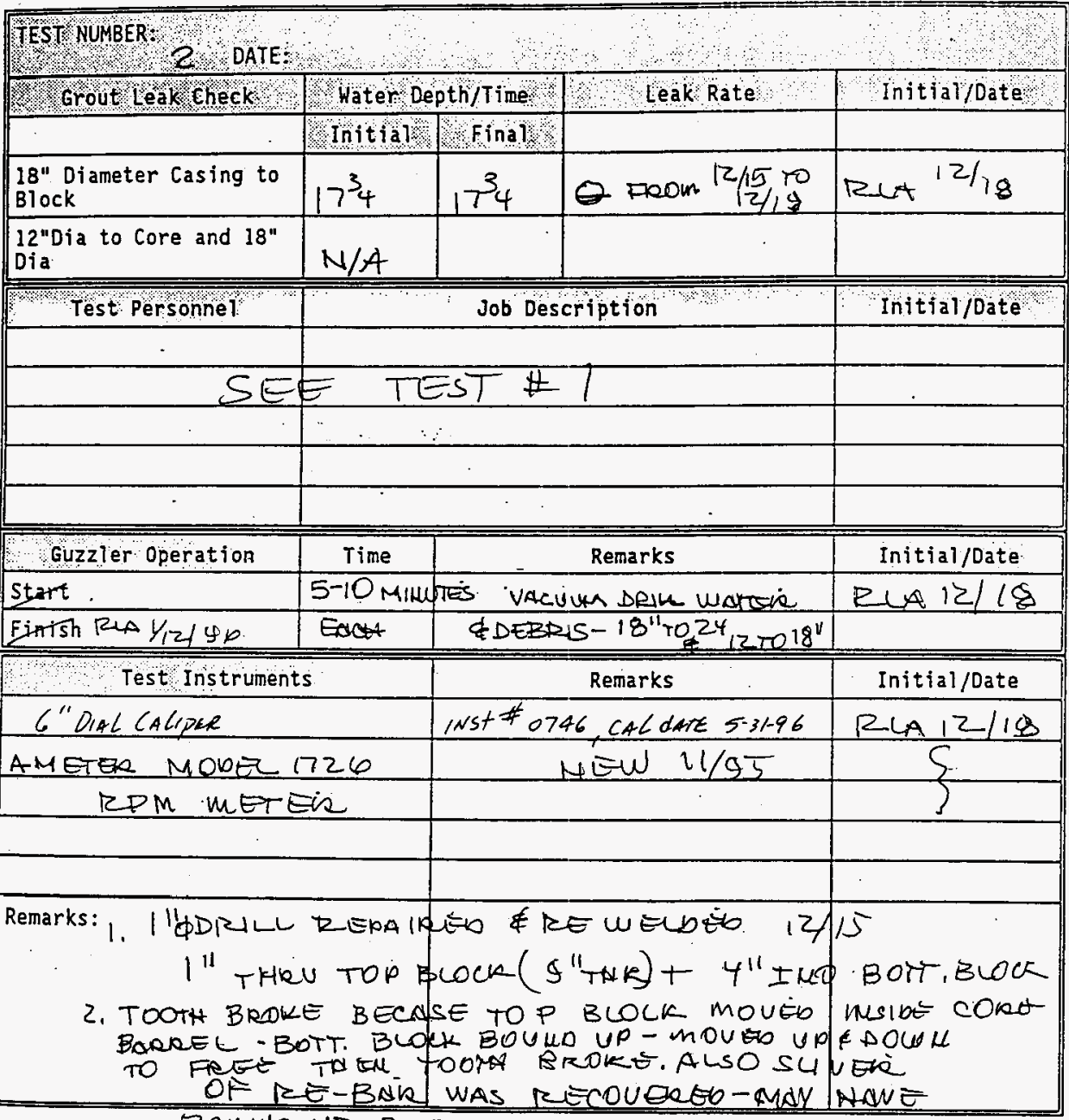
BOUMK UP BIT

Rev. 2, 11/29/95 cab 


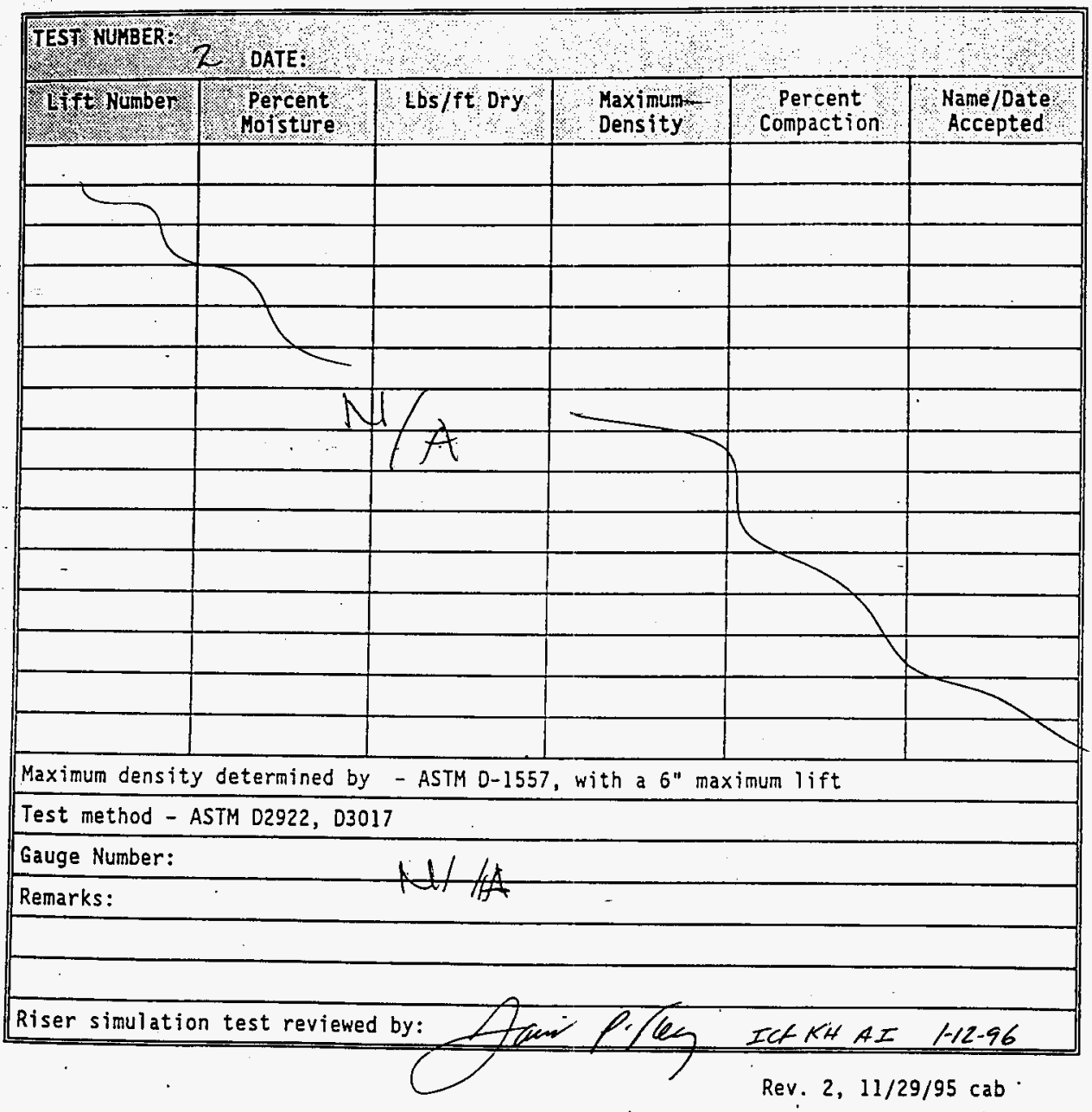




\section{RISER SIMULATION TEST \\ TEST PREPARATION DATA SHEET}

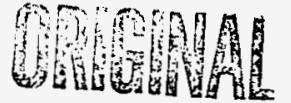

\begin{tabular}{|c|c|c|c|c|c|}
\hline \multicolumn{6}{|c|}{ TEST NUMBER: OATE: $12 / 14$ GTTO } \\
\hline & \multicolumn{4}{|c|}{ DESCRIPTION } \\
\hline \multicolumn{2}{|c|}{ Component } & & Size & Specification & Initialjoate \\
\hline \multicolumn{2}{|c|}{ Outer Casing } & \multicolumn{2}{|c|}{$24^{\prime \prime} 9 \times \frac{2}{8}$ size $x 2=0$} & $A 106-B$ & RA $12 / 4$ \\
\hline \multicolumn{2}{|l|}{ Inner Casing } & \multicolumn{2}{|c|}{$18^{\prime \prime} \Phi \times \frac{3}{8} \times 224$} & $A 106-B$ & 5 \\
\hline \multicolumn{2}{|l|}{ Riser } & \multicolumn{2}{|c|}{$N / A$} & & \\
\hline \multicolumn{2}{|c|}{ Riser Flange $R$} & S & & & 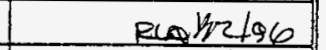 \\
\hline \multicolumn{4}{|c|}{ Core Retaining } & $A 3 \operatorname{tos} 53-B$ & $R 64 \% 12 / 19 / 8$ \\
\hline \multicolumn{2}{|c|}{ Epoxy Adhesive } & \multicolumn{2}{|c|}{$3 / 4^{11} \phi \times 66^{5}$} & 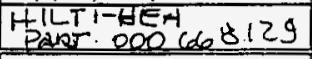 & $\int A F$ FOR \\
\hline \multicolumn{2}{|c|}{ Equipment/Supplies } & \multicolumn{2}{|c|}{ Description } & Supplier & Initial/Date \\
\hline \multicolumn{2}{|c|}{ Rotary Drill } & \multicolumn{2}{|c|}{$B-6 !+1 P$} & MOBIL DRILL & KLAIZ/4 \\
\hline \multicolumn{2}{|l|}{ Casing Shoe } & \multicolumn{2}{|c|}{$181800-D I N$ MNOH } & AHKSTERSEH & 5 \\
\hline \multicolumn{2}{|l|}{ Core Barrel } & \multicolumn{2}{|c|}{$14^{\prime} / 200-D I A m o u d$} & CLARISTEMSEN & \\
\hline \multicolumn{2}{|l|}{ Grout } & \multicolumn{2}{|c|}{ EDOXY GROTI } & FIVE STAK & f \\
\hline \multicolumn{2}{|c|}{ Guzzler } & \multicolumn{2}{|c|}{ TRUAK NOUUTEO } & Guzzl Ee inau Ut. & $\sum$ \\
\hline \multicolumn{2}{|c|}{ Other-BOOM TRuck } & \multicolumn{2}{|c|}{ Natoma } & OND F-80O TRUCK & S \\
\hline $\begin{array}{l}\text { Dimension } \\
\text { (Inches) }\end{array}$ & $W$ & 1 & Depth & Initial/Date & Remarks \\
\hline $\begin{array}{l}\text { Casing Shoe } \\
\text { Blocks } \\
1 \text {. }\end{array}$ & .545 & .798 & .334 & RLA $12 / 13$ & STAKT@61/2TOTa \\
\hline 2 & .529 & .800 & .348 & PLA & FEN 13 \\
\hline 3 & .532 & .751 & 352 & $1 / t_{0}$ & 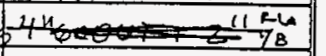 \\
\hline 4 & .536 & .800 & 1348 & & \\
\hline $\begin{array}{l}\text { Core Barrel } \\
\text { Blocks } \\
1\end{array}$ & .504 & .802 & .311 & $R L A 1 / 2 / 96$ & \\
\hline 2 & .500 & .794 & .309 & $s$ & \\
\hline 3 & .495 & .801 & .322 & $\zeta$ & \\
\hline 4 & .499 & .793 & .300 & & \\
\hline
\end{tabular}

Rev. 2, 11/29/95 cab 


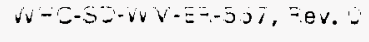

RISER SIMULATION TEST

TEST ACTIVITY DATA SHEET (Sh 1 Of 2)

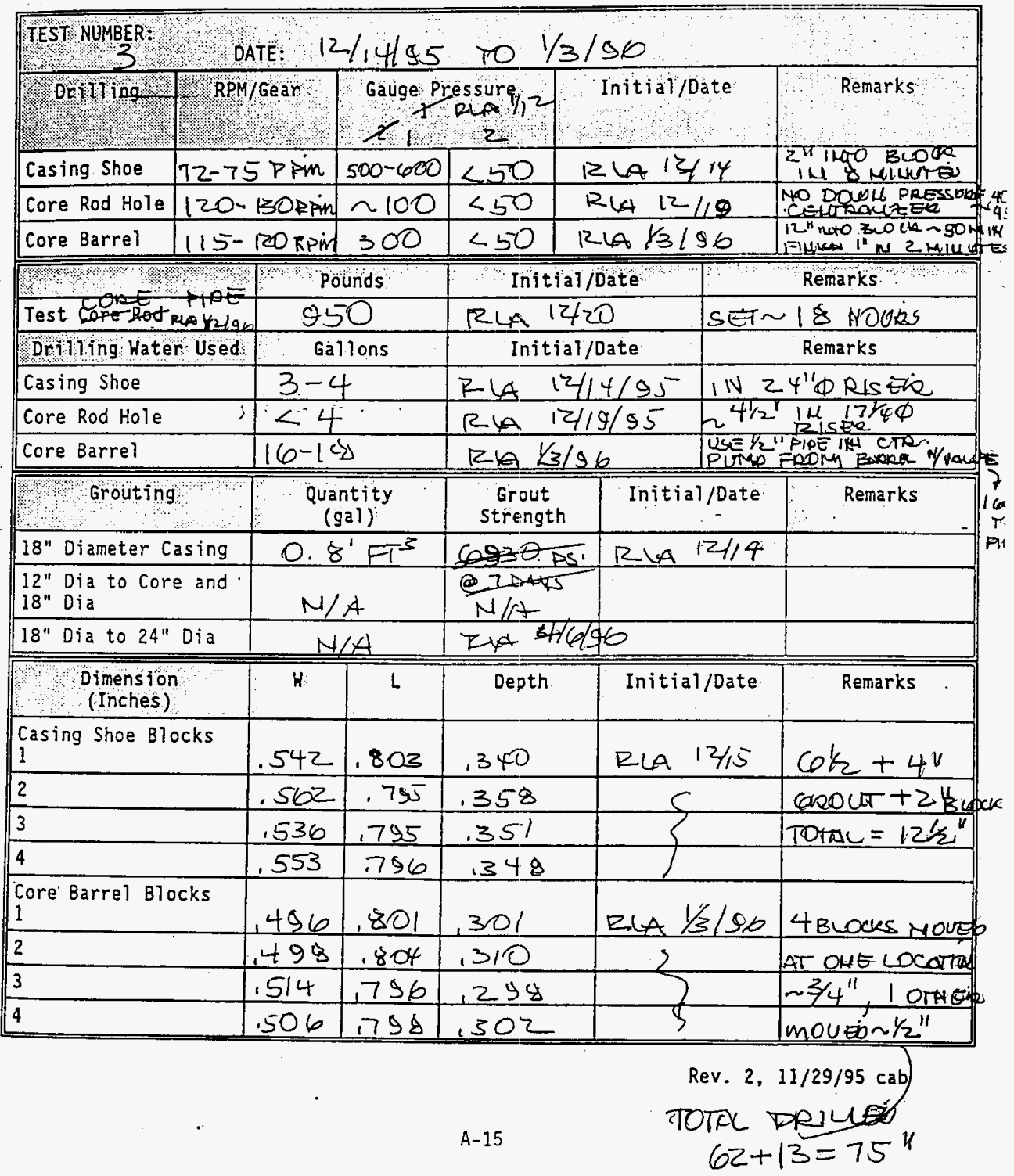




\section{RISER SIMULATION TEST \\ TEST ACTIVITY DATA SHEET (Sh 2 of 2)

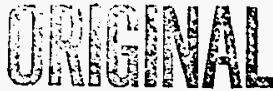

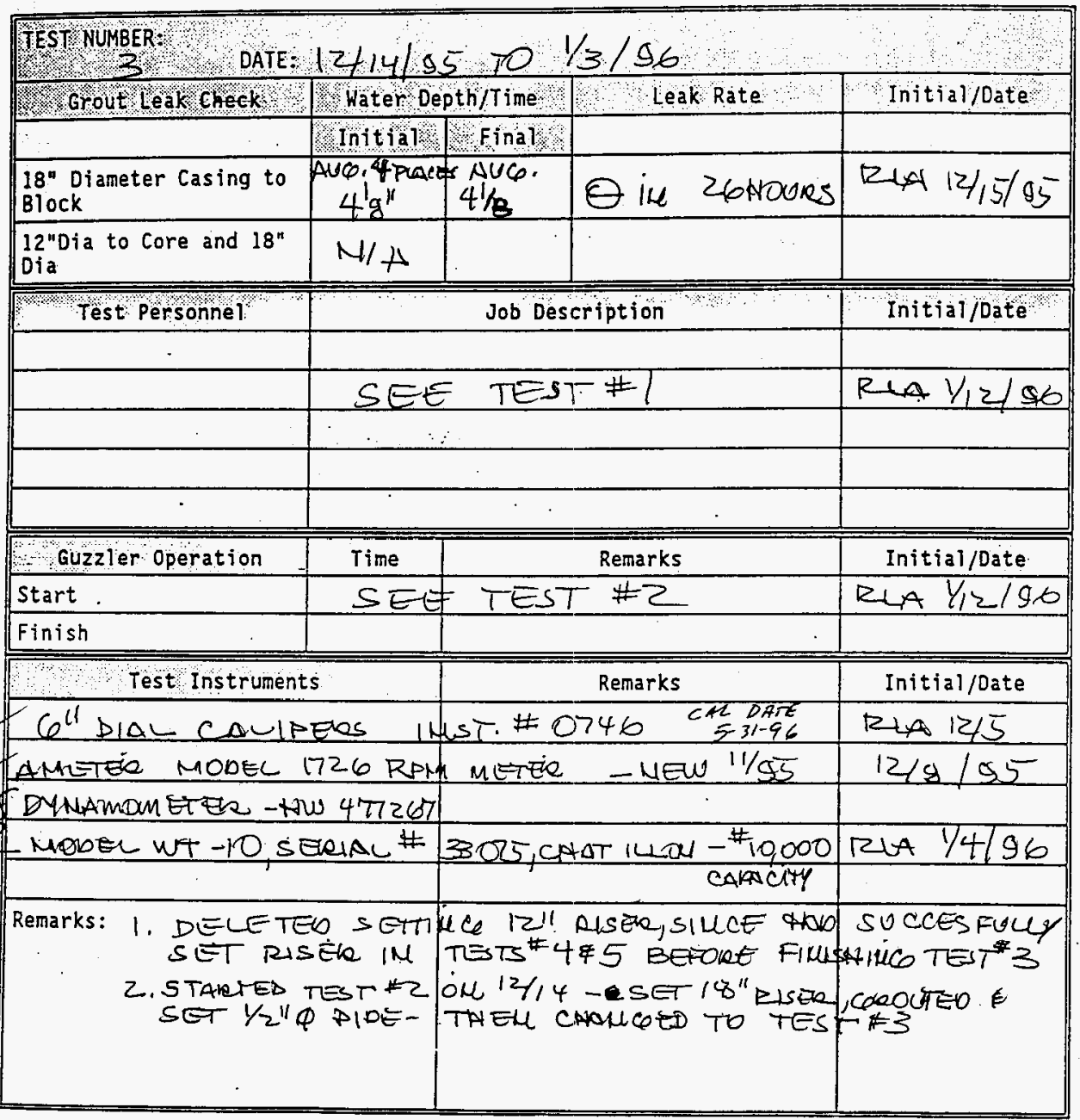

Rev. 2, 11/29/95 cab 


\section{RISER SIMULATION TEST \\ SOIL DENSITY DATA SHEET}
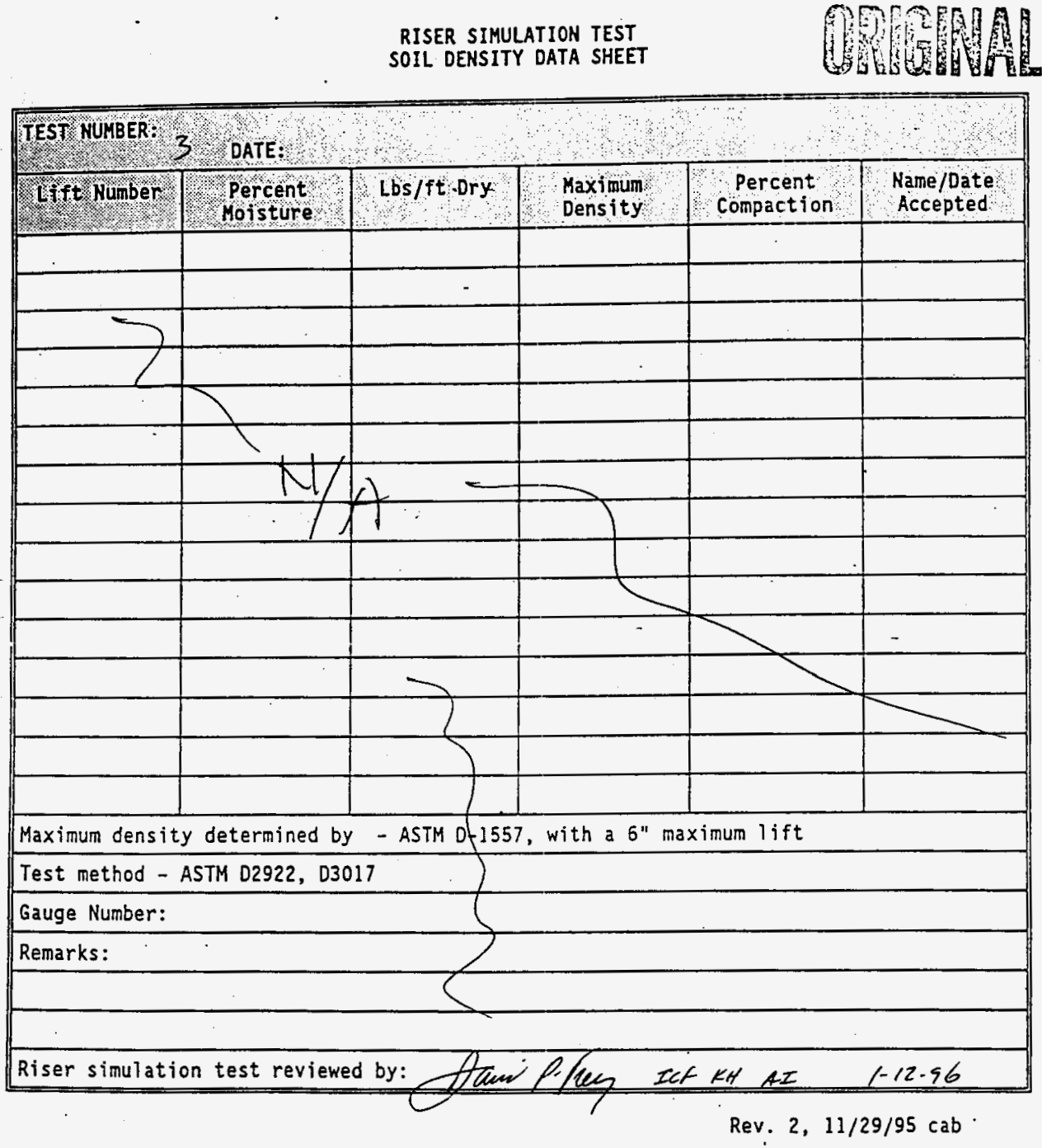
RISER SIMULATION TEST TEST PREPARATION DATA SHEET

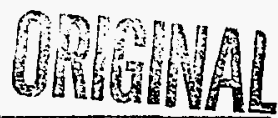

\begin{tabular}{|c|c|c|c|c|c|}
\hline TEST NUMBER & ATE: & $12 / 20$ & $\$ 5 T 0$ & $\begin{array}{l}\text { SET IHM O } \\
2 \% \text { PIPE, CORE }\end{array}$ & $\begin{array}{l}2 \text { CASIL G J CEURE } \\
=\text { DRIU JSET RUSE }\end{array}$ \\
\hline & & & & DESCRIPTION OL & SWOPE \\
\hline Component & 3 & & Size: & Specification & Initial/Date: \\
\hline Outer Casing & & 241 & $9 x^{3}=x 2-0$ & $A 100-B$ & RLA $12 / 20$ \\
\hline Inner Casing & & $18^{110}$ & $x^{3} \operatorname{tg} x<-8$ & $A-106 B$ & $?$ \\
\hline Riser & & $12^{\prime \prime} Q$ & $x^{3} y \times 3-9$ & $4106-B$ & $R$ LA $1 / 22$ \\
\hline Riser Flange & & & $/ A$ & & \\
\hline Core Retainin & A PII & $1 / 2$ & $\phi x \sim 2-0$ & $A \sqrt{33}-B$ & $\operatorname{LA}_{A} 1 / 22$ \\
\hline Epoxy Adhesiv & & $34^{110}$ & $\times 6^{5 / 8}$ & $\begin{array}{l}\text { HLT } \#+800000129 \\
\text { PART }\end{array}$ & $R(x+1 / 22$ \\
\hline Equipment/Sup & lies: & & scription & Supplier & Initial/Date: \\
\hline Rotary Orill & & $B-4$ & $01+4$ & MOBLL DRLL & RLA $12 / 20$ \\
\hline Casing Shoe & & 1818 & $O D \rightarrow$ Damoin & DARISTEUSEAL & $S$ \\
\hline Core Barrel & & $141 / 2$ & OD-DIAmoun & CARISTEHSEN & $\zeta$ \\
\hline Grout & & EPOXX & GeouT & LEIVE STAR & 2 \\
\hline Guzzler & & TRUC: & MOVǘËO & SUzZLER MaUUE & 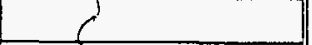 \\
\hline Other-Boots & Teuck & NATIO & 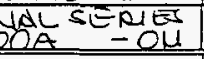 & Fono F 800 TRUCK & 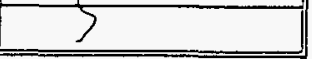 \\
\hline $\begin{array}{l}\text { Dimension } \\
\text { (Inches) }\end{array}$ & $\mathrm{H}$ & $\mathrm{L}$ & Depth & Initial/Date & Remarks \\
\hline $\begin{array}{l}\text { Casing Shoe } \\
\text { Blocks } \\
1\end{array}$ & .535 & .809 & .329 & RLA $12 / 15$ & गत्या@12kTota \\
\hline 2 & .555 & .795 & .350 & 5 & \\
\hline 3 & .536 & .795 & .350 & $\zeta$ & \\
\hline 4 & .538 & .792 & 342 & 7 & \\
\hline $\begin{array}{l}\text { Core Barrel } \\
\text { Blocks } \\
1\end{array}$ & .509 & .800 & 1316 & RLA $12 / 19$ & 31"@s stakt \\
\hline 2 & .517 & .758 & 1305 & 5 & \\
\hline 3 & 512 & .796 & .314 & & \\
\hline 4 & .522 & .795 & 1314 & & \\
\hline
\end{tabular}

Rev. 2, 11/29/95 cab 


\section{RISER SIMULATION TEST TEST ACTIVITY DATA SHEET (Sh 1 of 2)}

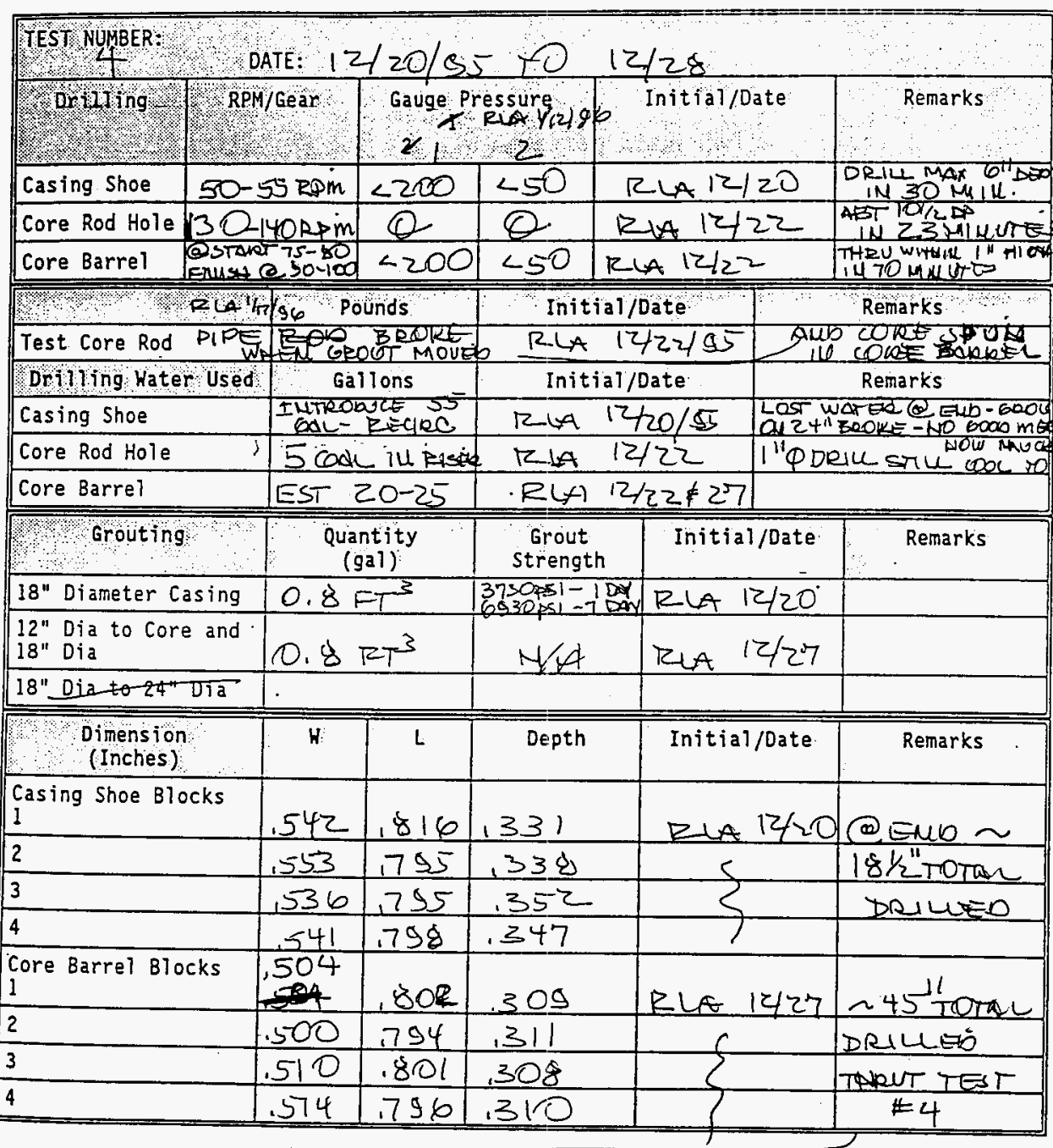

2 Rev. 2, 11/29/95 cab

2 PLOCKS MOUEO AFTER TEST \#4, RE SE \& DU BLOCKS ON" CORE BARREL EXTRA BRdZE 


\begin{tabular}{|c|c|c|}
\hline \multicolumn{3}{|c|}{ TEST NUMBER 1 , DATE $/ 2 / 20 / 9570 / 2 / 28$} \\
\hline \multirow{2}{*}{\multicolumn{3}{|c|}{ 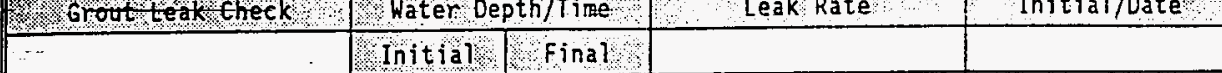 }} \\
\hline & & \\
\hline $\begin{array}{l}\text { 18" Diameter Casing to } \\
\text { Block }\end{array}$ & 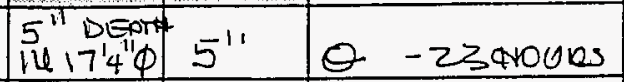 & ZuA $12 / 22,55$ \\
\hline \multicolumn{2}{|c|}{ 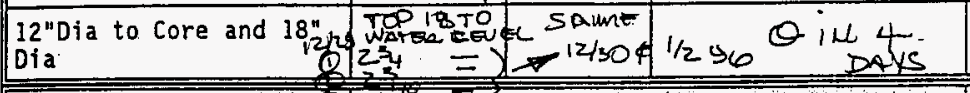 } & $\operatorname{Rln} 1 / 2 / 56$ \\
\hline \multicolumn{2}{|c|}{ 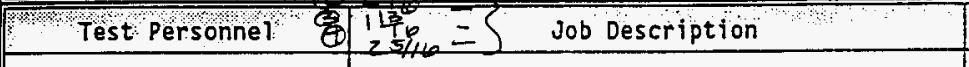 } & Initial/oate \\
\hline \multicolumn{3}{|c|}{\begin{tabular}{|l|l|}
$\cdot$ & \\
\end{tabular}} \\
\hline \multicolumn{2}{|r|}{ SEE TESTEI } & $2641 / 12 / 90$ \\
\hline & \\
\hline \multicolumn{2}{|l|}{ 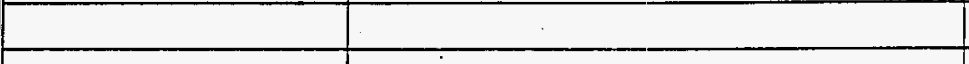 } & \\
\hline \multicolumn{2}{|l|}{$\cdot+$} & \\
\hline Guzzler Operation & Remarks & Initial/Date \\
\hline \multirow{2}{*}{$\begin{array}{l}\text { Start } \\
\text { Finish } \\
\end{array}$} & SEt $1 \mathrm{te} \# 2$ & \multirow[t]{2}{*}{$24+1 / 2 / 9$} \\
\hline & & \\
\hline Test Instruments & Remarks & Initial/Date \\
\hline 6" DIAL CALIPEA & |NST $40746-$ CAC dATE S.31-96 & \\
\hline \multicolumn{2}{|c|}{ AMETER MOOE $720 \mathrm{RPM}$ HEW $11 / 95$} & \\
\hline \multicolumn{3}{|c|}{ meteic } \\
\hline \multicolumn{3}{|c|}{$24 R+12 / 96$} \\
\hline \multicolumn{2}{|c|}{ 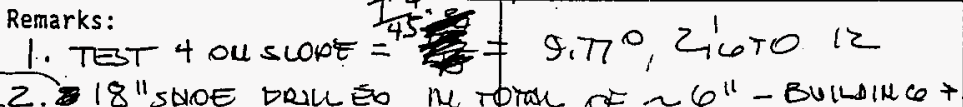 } & \\
\hline \multicolumn{2}{|c|}{ 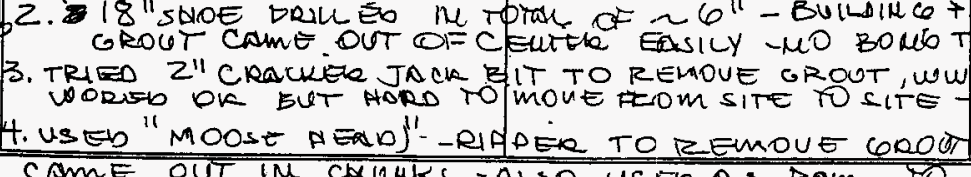 } & 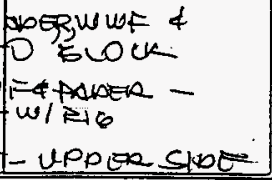 \\
\hline CAMUE OUT IM C & QUसKS - AWSO USEO AS RAm FO & \\
\hline
\end{tabular}
mobe GoOb PROGaES he OBOUT $\$$ minutes. Rev. 2, 11/29/95 cab 


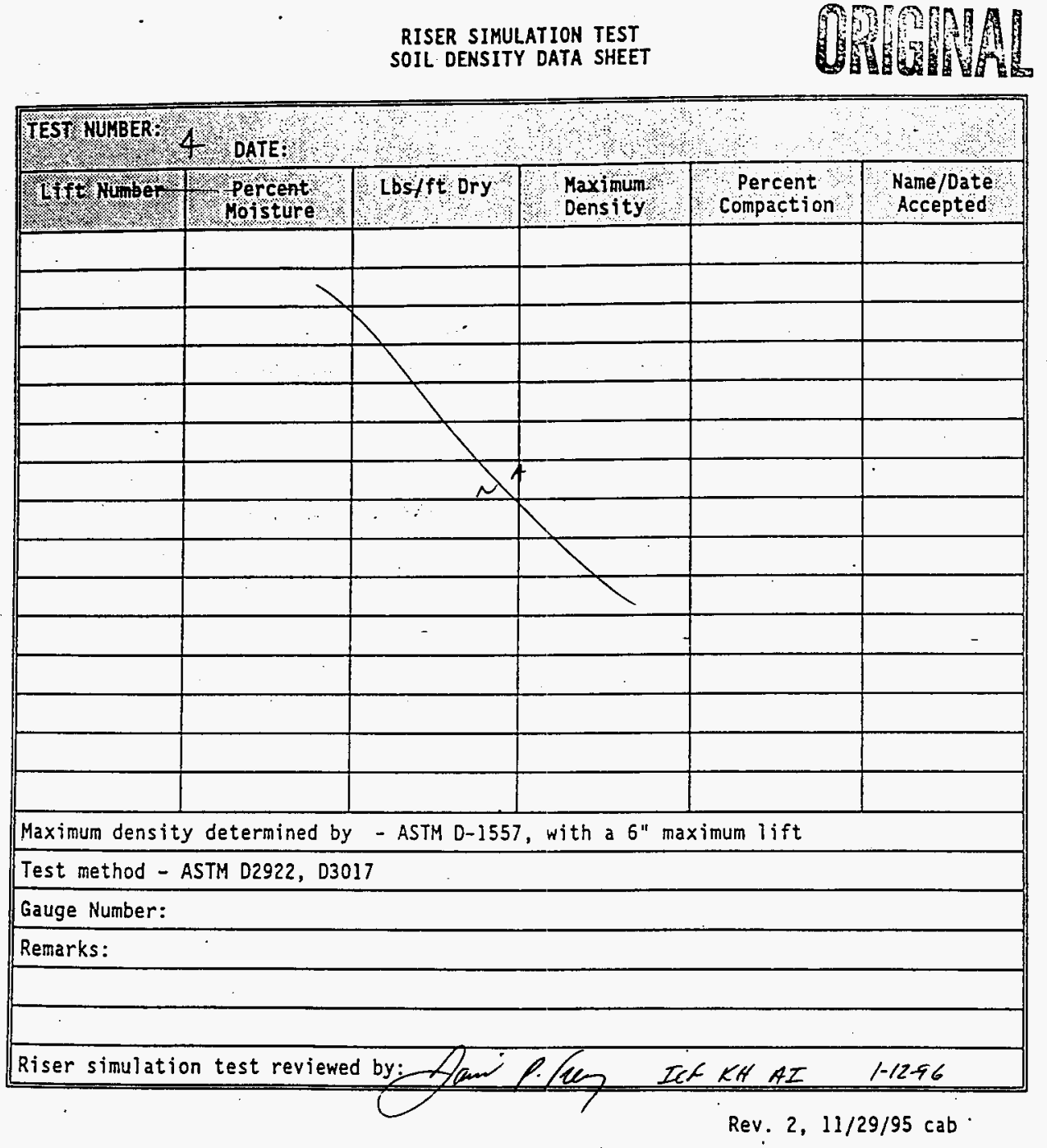




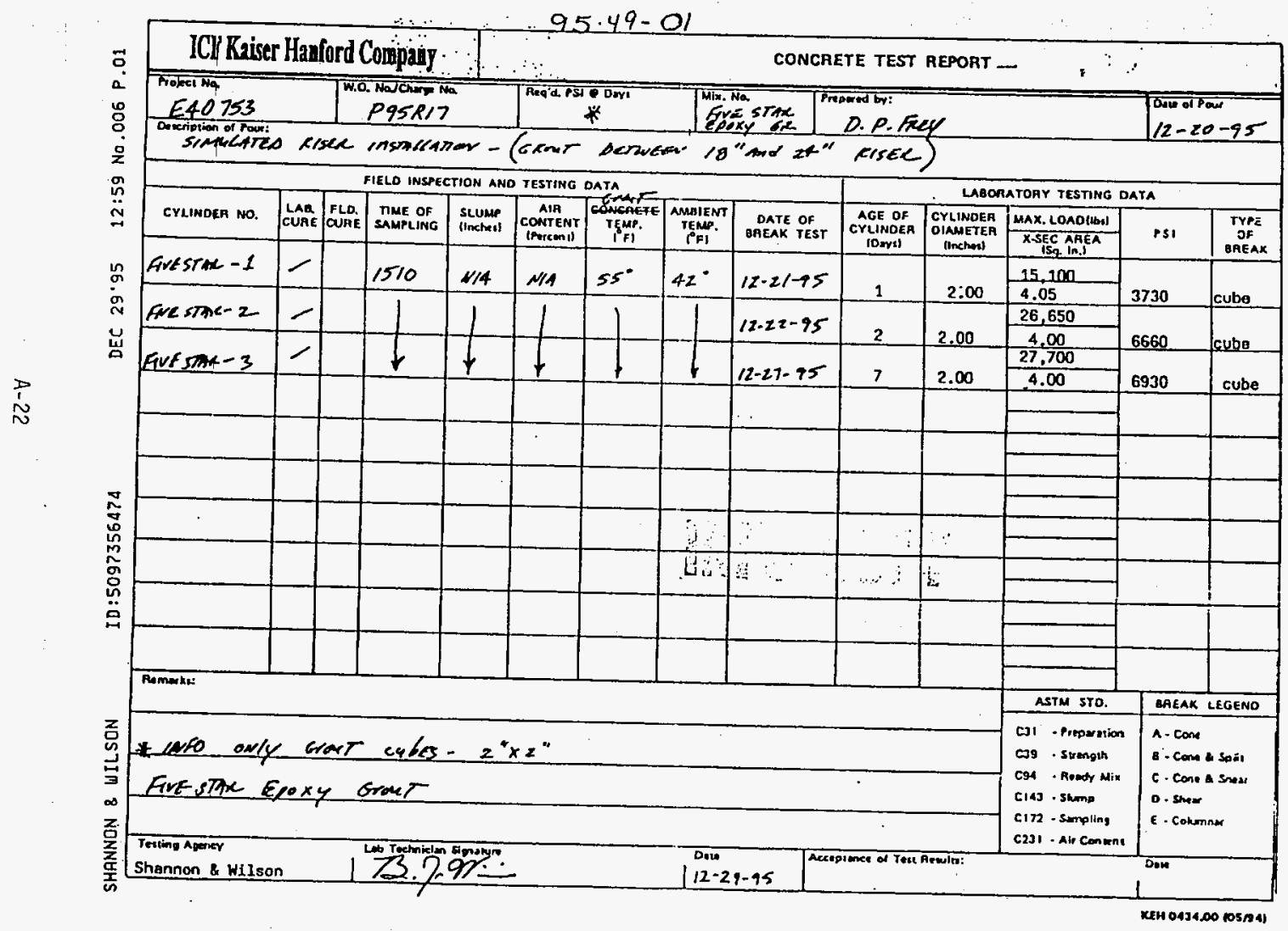




\section{RISER SIMULATION TEST \\ TEST PREPARATION DATA SHEET}

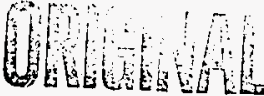

\begin{tabular}{|c|c|c|c|c|c|}
\hline \multirow{2}{*}{\multicolumn{2}{|c|}{ TEST NUMBER: 5 DATE: }} & \multicolumn{4}{|c|}{ SIMULATED TLSSER } \\
\hline & & \multicolumn{4}{|c|}{ DESCRIPTION } \\
\hline \multicolumn{2}{|c|}{ Component } & \multicolumn{2}{|r|}{ Size } & Specification & Initiat/Date \\
\hline \multicolumn{2}{|l|}{ Outer Casing } & \multicolumn{2}{|c|}{$24^{\prime \prime} 9 \times \frac{3}{8} \times 11^{1-2}$} & $A-106 B$ & RLA $12 / 28$ \\
\hline \multicolumn{2}{|l|}{ Inner Casing } & \multicolumn{2}{|c|}{$18 " \phi x=8-11-10$} & $A 106 B$ & $24 \times 1 / 2$ \\
\hline \multicolumn{2}{|l|}{ Riser } & \multicolumn{2}{|c|}{$12^{\prime \prime} 9 \times 3 \times 13-6$} & $4-106 B$ & $S$ \\
\hline \multicolumn{2}{|c|}{ Riser $\mathrm{Flange}$} & \multicolumn{2}{|c|}{$12^{\prime \prime} Q$ SLP ON } & $A-105$ & \\
\hline \multicolumn{4}{|c|}{ Core Retaining Rod $P A=1 / 2 " Q=C P 40 \times-15^{\prime}$} & 153 & \\
\hline \multicolumn{2}{|c|}{ Epoxy Adhesive } & \multicolumn{2}{|c|}{$2 \pi U B E 5{ }^{5} \times 3 / 4^{\prime \prime} p$} & $\begin{array}{l}\text { HLT } \\
\text { PAR } \# 0006 \text { 68129 }\end{array}$ & 4412129 \\
\hline \multicolumn{2}{|c|}{ Equipment/Supplies: } & \multicolumn{2}{|c|}{ Description } & Supplier & Initial/Date \\
\hline \multicolumn{2}{|l|}{ Rotary Drill } & \multicolumn{2}{|c|}{$B \div 6.1 N D$} & MOBIL DRILL & $z(A / 20 / 95$ \\
\hline \multicolumn{2}{|l|}{ Casing Shoe } & \multicolumn{2}{|c|}{ 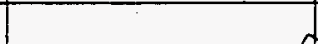 } & $\gamma$ & \\
\hline Core Barrel & & \multicolumn{2}{|c|}{ SEE TESTS } & 1 TNien 4 & \\
\hline Grout & & & DNASTER BULLEER & \\
\hline \multicolumn{2}{|l|}{ Guzzler } & \multicolumn{2}{|c|}{928 MASTZEFLOÜ } & & \\
\hline \multicolumn{2}{|l|}{ Other } & & \multirow[b]{2}{*}{ Initial/Date } & \\
\hline $\begin{array}{l}\text { Dimension } \\
\text { (Inches) }\end{array}$ & H & L & Depth & & Remarks \\
\hline $\begin{array}{l}\text { Casing Shoe } \\
\text { Blocks } \\
1\end{array}$ & .542 & .816 & 331 & $12 / 28 / 55$ & @stakt $181 / 2 "$ \\
\hline 2 & .553 & .795 & 338 & 6 & TOTIL DRULE \\
\hline 3 & 536 & .755 & 352 & & \\
\hline 4 & .541 & .798 & .347 & ) & \\
\hline $\begin{array}{l}\text { Core Barrel } \\
\text { Blocks } \\
1\end{array}$ & 531 & .804 & $\begin{array}{l}\text { RLA Y/2/\% } \\
.315\end{array}$ & RLA //2/S0 & 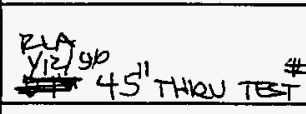 \\
\hline 2 & .518 & .803 & .325 & & BRAEE ALC DSC \\
\hline 3 & 1520 & 819 & 1348 & 2 & U'siLv uQ unen \\
\hline 4 & .525 & 1795 & .327 & & \\
\hline
\end{tabular}

Rev. 2, 11/29/95 cab 


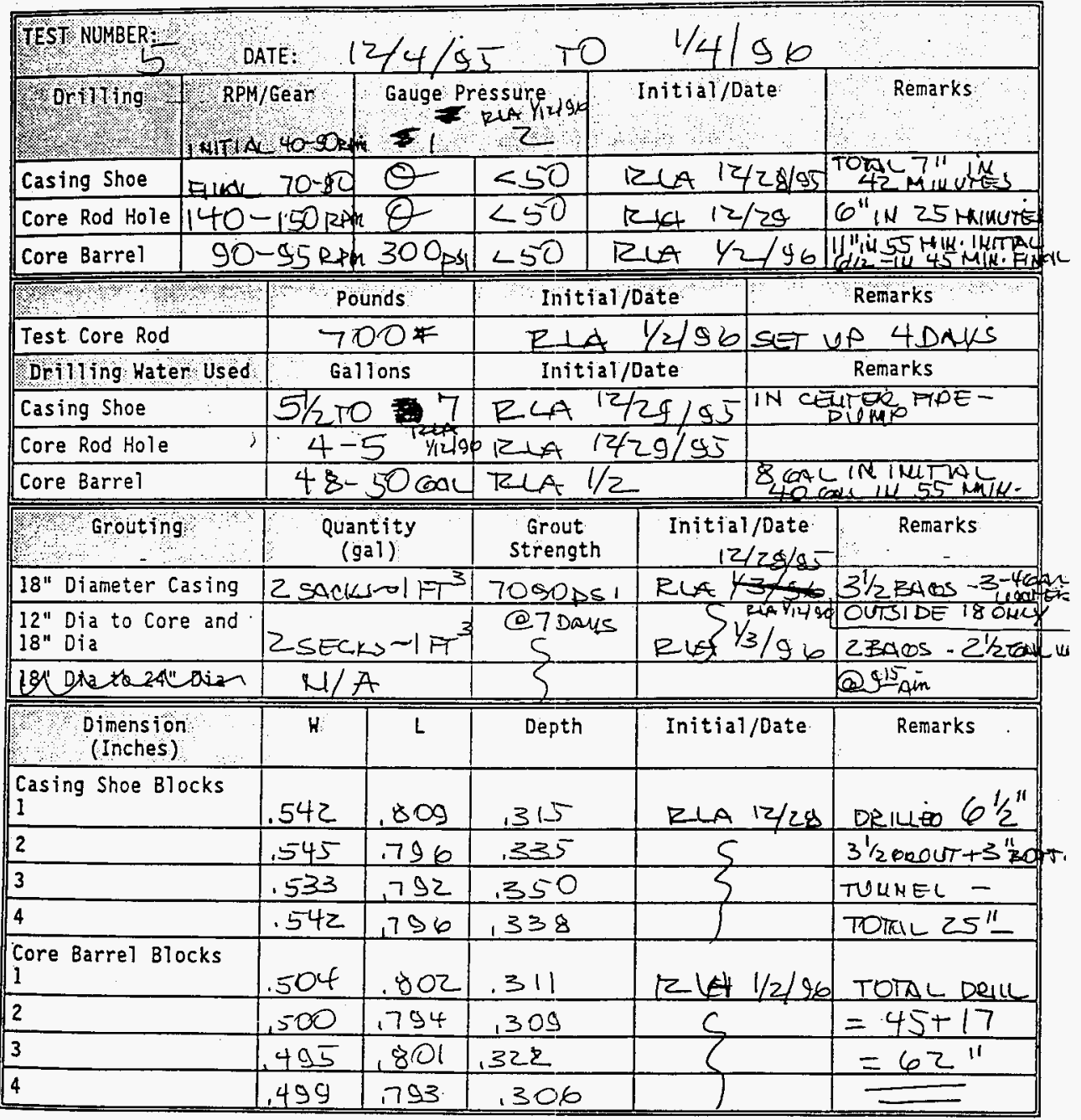

Rev. 2, 11/29/95 cab 


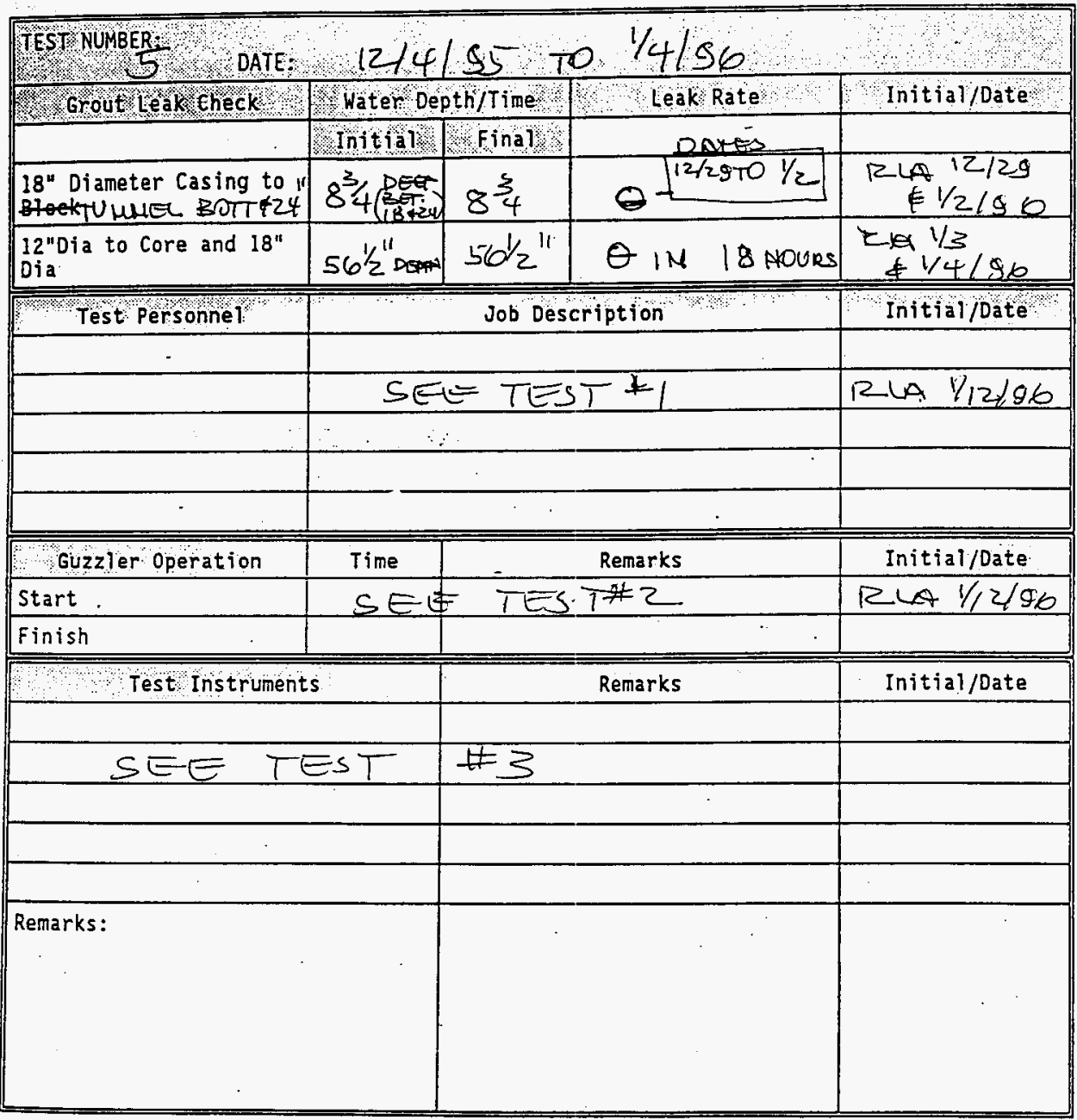

Rev. 2, 11/29/95 cab 
RISER SIMULATION TEST

SOIL DENSITY DATA SHEET

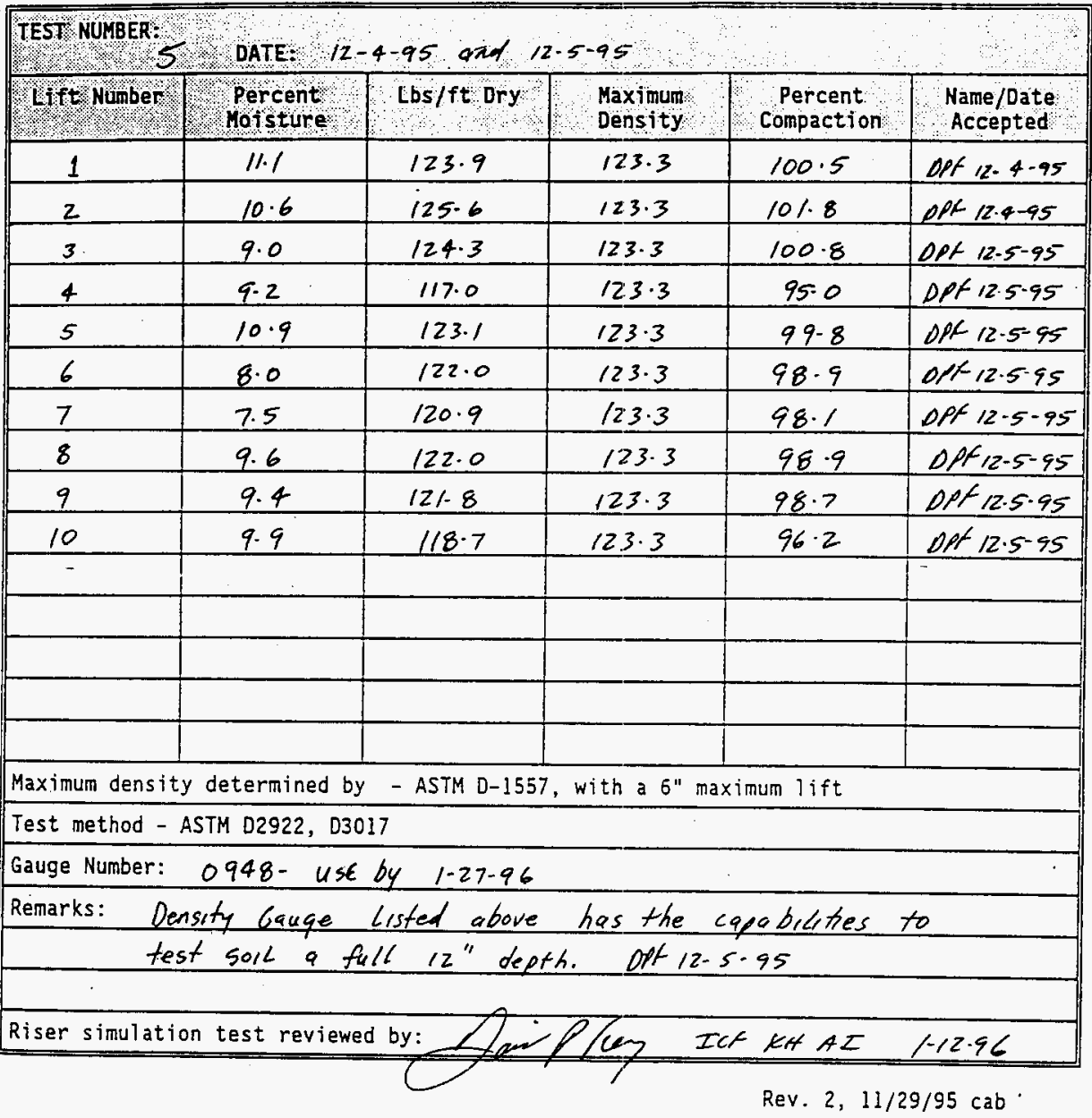




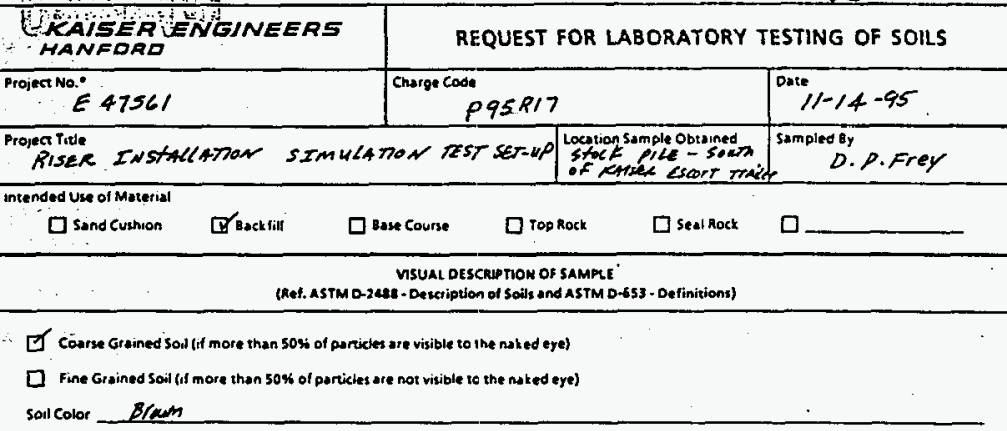

PEAFORM THE FOLLOWAG TEST(S)

DSTM C.117 Stondard Test Method for Materiak Funer than N0.200 Sieve in Mineral Aggegates by Washing

[ ASTM C.136 Standard Test Method for Sieve or Screen Analysus of fine and Coarse Aggregates (see REMARKS for sieve sizes)

D ASTM D-A22 Standard Test Method for Paricie Size Analysis of Sithls

D.

ASTM D.1557 Standard Test Methods of Maisture-Density Relauons of Soil Aggregate Mixtures Using 1-16. Rammer and 18- Drop $\quad \forall$

口 ASTM D.a2s3 Maximum index Density of Soils using a vibratory Table

$\square$ AStMO 0254 Minimum index of Sorts and Cakulation of Aelative Denity

[] WsDor.605a Compaction Control Tert for Granular Material

W wDOT-609 Method of Test for Moisture-Density Relations of Soll

\begin{tabular}{|c|c|c|c|c|c|}
\hline \multicolumn{6}{|c|}{ FOR SIEVE ANALY SIS, CMICK RE QUIREO SIEVE SIZES } \\
\hline $\mathbb{G}_{3}$ & $\square^{1.1 / 4}$ & $\square^{1 / 2}$ & $\square 6$ & $\square 20$ & $\square 80$ \\
\hline$\square 2 \cdot 12$ & $\mathbb{8}$ & $\square 3$ & 口: & $\square 30$ & $\square 100$ \\
\hline$\square^{2}$ & $B_{3 / 4}$ & $D^{1 / 4}$ & [] 10 & $\square 40$ & E 200 \\
\hline$\square^{1.12}$ & $\square$ ss & $\nabla_{4}$ & 016 & Dso & $\square$ \\
\hline \multicolumn{6}{|c|}{ Rrmanks } \\
\hline \multicolumn{6}{|c|}{ procsoukz "A ". } \\
\hline
\end{tabular}

- Artach rog to sample container indicating Projert No. and Sample No Oistrubution: Onginal to Testing Lab-Copy to Project file 
NDV 27.95 i3:39 No.007 P.02

SHANNON \& WILSON, INC. Muteacls Testing Laboratory

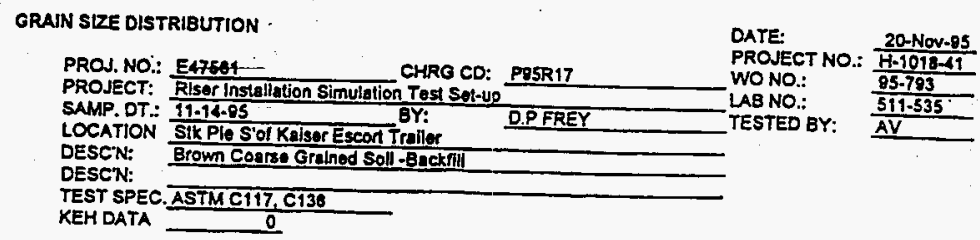

\begin{tabular}{|c|c|c|c|}
\hline $\begin{array}{l}\text { STEVEOR } \\
\text { SCREEN } \\
\text { (n. or No.) }\end{array}$ & $\begin{array}{c}\text { OPENINO } \\
\text { SIZE } \\
(\mathrm{mm})\end{array}$ & $\begin{array}{l}\text { PERCENT } \\
\text { PASSING }\end{array}$ & $\begin{array}{l}\text { PROJECT } \\
\text { SPEC. }\end{array}$ \\
\hline $\begin{array}{l}6 \\
5\end{array}$ & $\begin{array}{r}152.88 \\
127.4\end{array}$ & $\begin{array}{r}100 \\
100\end{array}$ & \\
\hline 3 & 76.44 & 100 & \\
\hline 1.25 & 31.85 & 98 & \\
\hline & 25.40 & 24 & \\
\hline 0.75 & 10.11 & 82 & \\
\hline 0.5 & 12.74 & 80 & \\
\hline 0.375 & 0.555 & 88 & \\
\hline 4 & 4.75 & 85 & \\
\hline 10 & 2 & 78 & \\
\hline 20 & 0.85 & 59 & - \\
\hline 40 & 0.425 & 39 & \\
\hline so & 0.3 & 34 & . \\
\hline 100 & 0.15 & 28 & \\
\hline 2001 & 0.075 & 18.0 & \\
\hline
\end{tabular}


NOV $27^{\circ}$.9S is:39 No.007 P.03

SHANNON \& WILSON, INC. MATERINLS TESTING LAOORATOAY

PROCTOR TEST REPORT

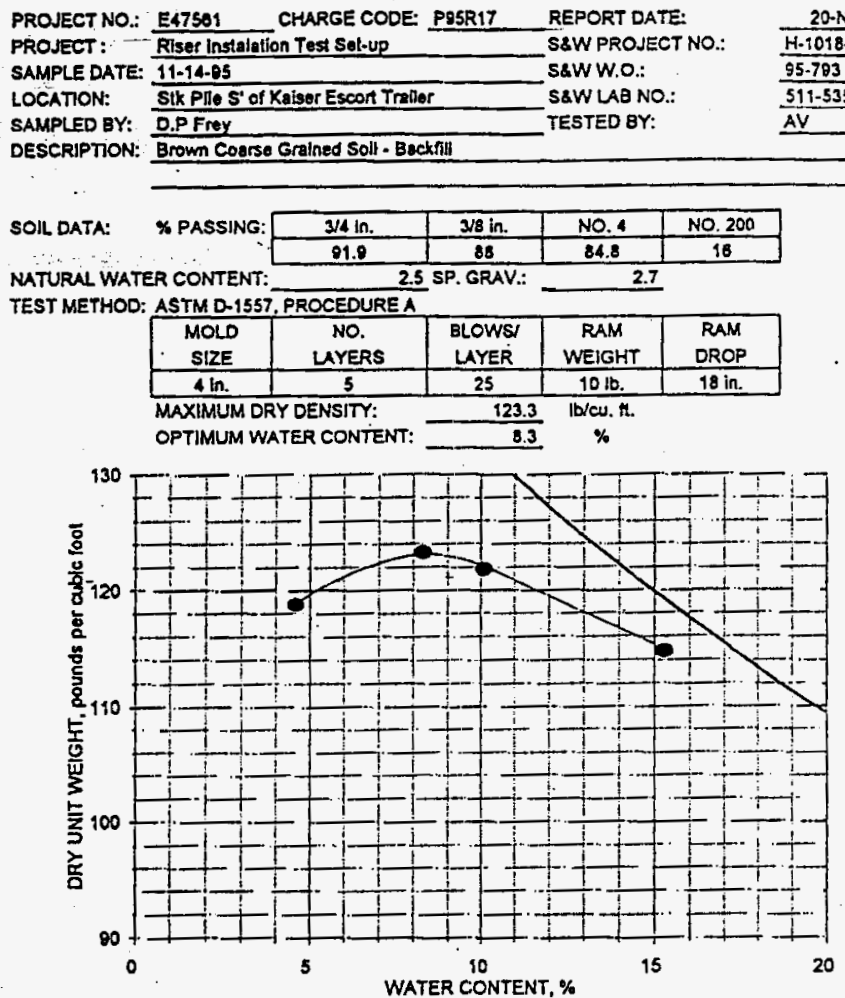

COMMENTS: KEH SMMPLE:

E47581.1

CHECKED: DATE: $1-22-95$

80 WELLTAN WAY 


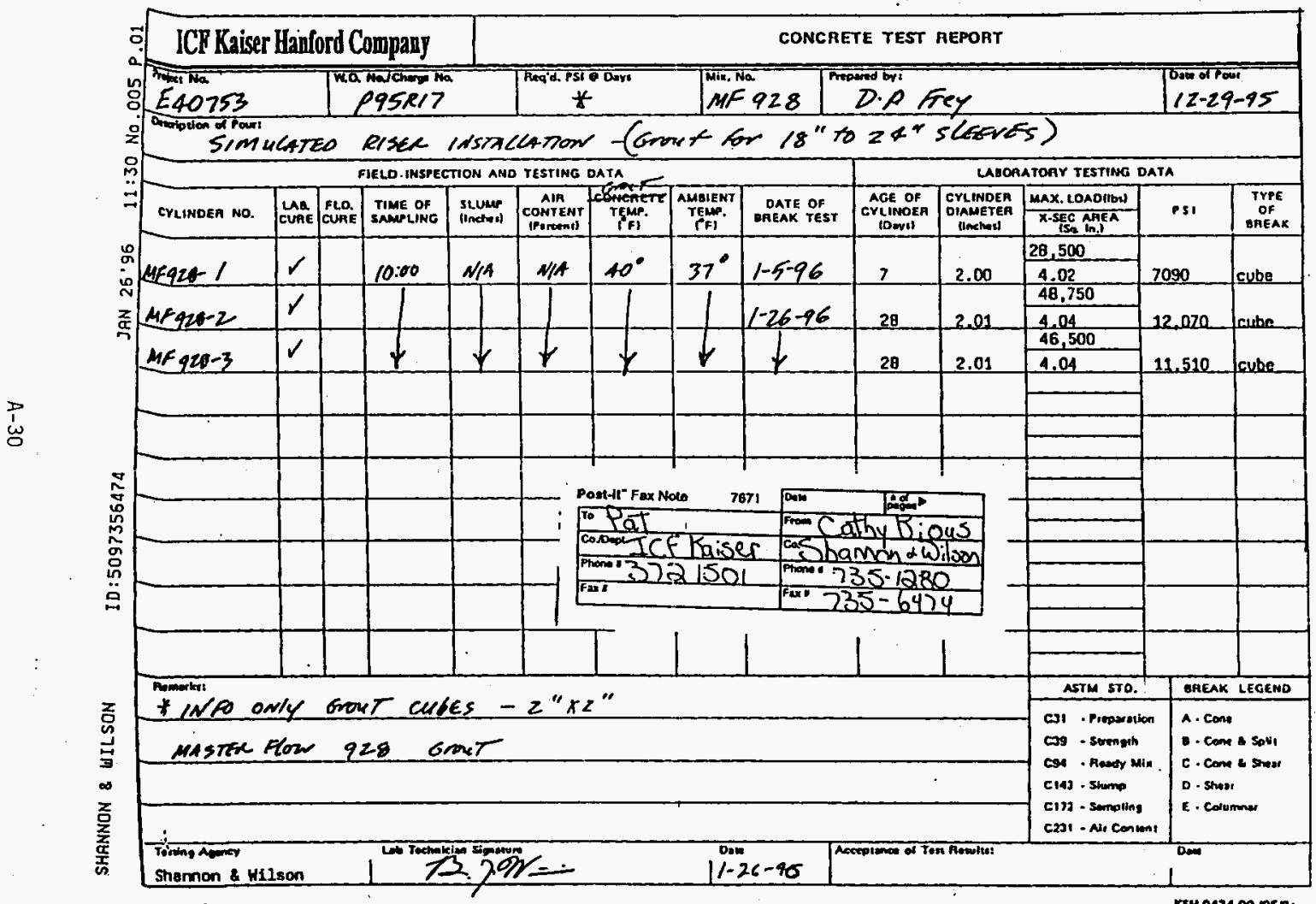

KEH OA34 00 NOSBS. 


\section{APPENDIX B}

\section{Daily Activity Log}




\section{DAILY ACTIVITY LOG}

A diary was kept on the daily activities of the simulated riser installation field test activities by the ICF KH test engineer, R. L. Ackerman.

The field test activities began with mobilization the fourth week of November 1995 , drilling activities began December 7, 1995, and were completed January 5, 1996.

The field notes were typed for clarity: the original hand-written notes are on file.

1 certify that the following is an accurate transcription of the field activities diary I kept during the simulated riser installation tests.

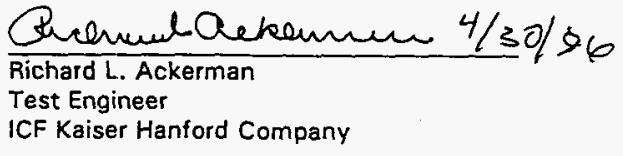




\section{Field Activities}

R. L. Ackerman

\section{NOVEMBER 27,1995}

\section{Site Preparation}

1. Test all 4 lifting points on 6 hatch covers, all to 1,500 pounds minimum vertically 2.5 times lifting force. Wrote memo to file.

2. Lifted cover block - tunnel is clear of all pipes, very little water on bottom.

3. Cut 4 pieces - 24 -inch 2 feet long pipe for outer risers. 11 feet 2 inches still left for simulation test.

4. Setting $4-24.3 w / 3$ angle supports wedge. Anchor to block, other $w / 4$ supports in slope to set.

5. Took off 2 cover blocks where CMP is: looks OK. Reset.

STILL NEED:

1. 928 grout (already on site $11 / 29$ ), order by Mike Neville $11 / 27$

2. Plain grout - on site?

3. 12-inch riser - on site?

4. 12-inch blind flange - order?

5. rpm meter - on order

6. Flow meter - move to field.

\section{November 28, 1995}

Setting 24-inch diameter outer casings Safety JSAS 
NOVEMBER 29,1995

\section{Site Preparation}

1. Permits to enter tunnel

2. Permits to cut CMP

3. Roofing paper and mesh

4. Grout found.

Set last of 324 -inch-diameter casings on cover blocks - move or not, cut $/ 1 / 2$-inch diameter bolts

\section{Sloped Block Preparation}

Wrap 2 layers roofing paper and 1 layer $6 \times 6 \times 9$-inch wide - $22 \times 6$ bars on back Setting 24-inch casing on slope - may not be quite $10^{\circ}$ as shown, measure

\section{Tunnel Bottom Preparation}

Plan to use 5-foot bars at tunnel bottom for wire mesh

2 layers roofing paper - green color, good tracer

Marked CMP at 10 feet 6 inches - depth 10 feet 3 inches to 10 feet 4 inches Need more brackets for bottom

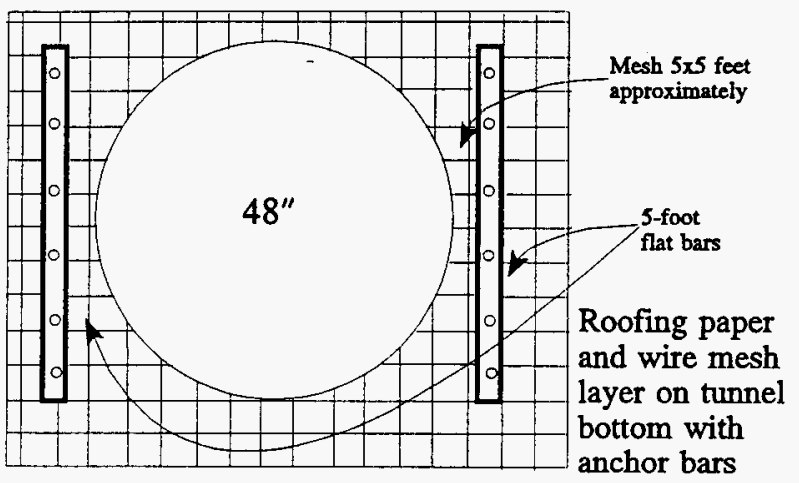




\section{NOVEMBER 30.1995}

\section{Site Preparation}

1. Cut CMP to 10 feet 6 inches

2. Some asbestos in tunnel - require plastic barriers each side of work

3. Finish installing 24-inch on slope

4. Need to modify flange to fit 18-inch casing shoe to rig

\section{DECEMBER 1, 1995}

\section{Site Preparation}

Set 48-inch CMP to bottom - bottom w/4

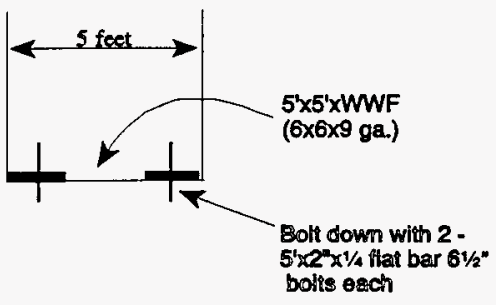

4 bags grout used - depth about 3.8 to 4 inches

$5 \times 2 \times 1 / 4$ flat bar $61 / 2$

bols each

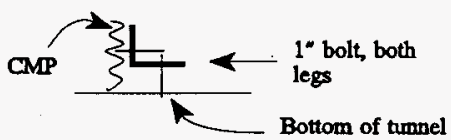

Bottom of tumnel 


\section{DECEMBER 4, 1995}

\section{Structural Fill Compaction}

2 lifts of about 1 foot each in $48^{\prime \prime}$ CMP

first tested about $100 \%$ of $D 1557$

second tested $101 \%$ of D1557

Shut down about 1 p.m. - no safety for fall protection - signed by 2:30 p.m.

Ready to start $12 / 5$ a.m. - should finish filling CMP

Received drill bits and subadaptor from Christensen - all OK - will fit

DECEMBER 5,1995

Structural Fill Compaction

Finished compacting soil at 11:30 a.m.

Total 10 tests all exceeded $95 \%$ required - approximately 10 feet $+(4$ inches $)$ grout soil column

\section{Cover Block Preparation}

Grouting test 4, 24-inch risers

Measured diamond/matrix 18 -inch shoes and core barrel - recorded.

Lenny modifying 18 " casing shoe connection. 


\section{DECEMBER 6,1995}

\section{Complete Site Preparation}

1. Grout into slant on slope for Test 4 cover block.

- About 2 inches on low side

- About $1 / 2$ inch on high side

- Cure now in Igloo

2. Move trailer for stand.

3. Fix 18-inch connection

- Ready to go now

- Start tomorrow

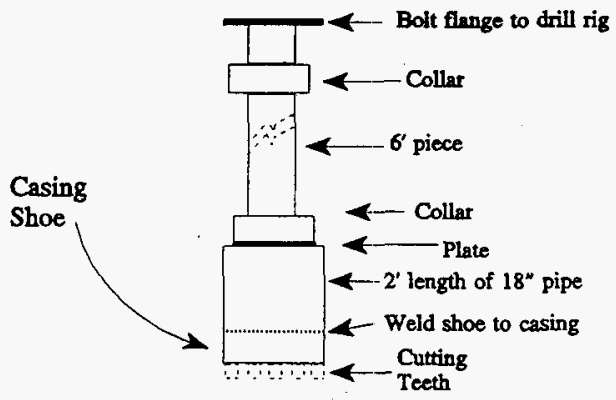

Casing shoe drill string and $18^{\prime \prime} \$$ bit 


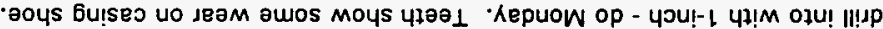

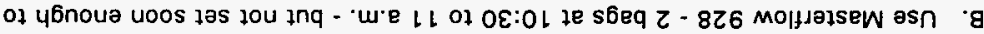
วกo

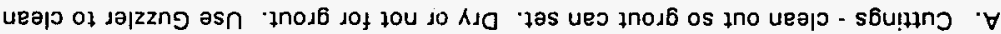
Wᄏาgoyd

os 10 „\%-乙 o6 of selnu! $02-9 L-4 s ! 4 ! y$

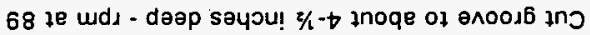

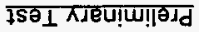

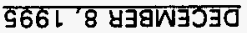

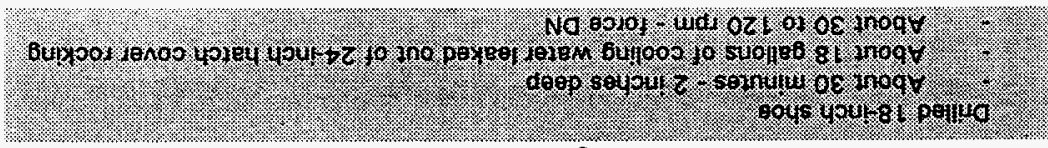

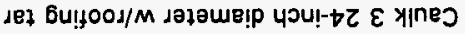

Joldepe 6!̣ uo eous you!-8l pןem pue inj

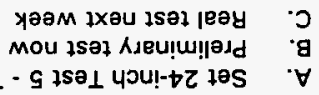

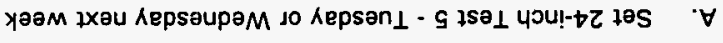

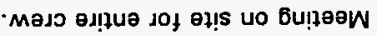

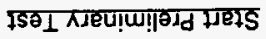
$9661 \cdot L 9806350$ 


\section{DECEMBER 11,1995}

\section{Preliminary Test}

Fit 1 -inch drill with centralizer to drill rig

Into grout about 4 inches and into concrete about. 1 inch. Drill rod broke in 2 places, hold back on pressure:

- Drill rod may have been out of plumb, hole ended up 1 inch off center

- Epoxy grout in hole stuck up about 2 inches above; ground down and mixed

- Concrete and steel were cold, temperature topped at $33^{\circ} \mathrm{F}$. Heat up later about 1 hour

- Pulled on rod, separated grout from cover block. Clean break

- Then drilled with core barrel drill to within 1 to $1-1 / 2$ of bottom

- $60-70 \mathrm{rpm}$, little down pressure, 15 to 20 gallons water.

\section{DECEMBER 12,1995}

Finished 1 to $1-1 / 2$ inches of core - dropped to bottom of trench

Recovered core - rebar very clear. One bar at bottom parallel to drill - clean cut.

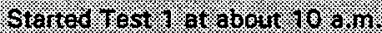

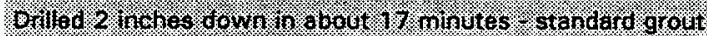

\section{CMP Excavation}

Started hole for 24-inch casing (Test 5) at 1:20 p.m. - at 1:54 down about 20 inches by hand and Guzzler

- Set 6'2" long piece of 24-inch - used Guzzler

- By 2:30 to 2:40 advanced about 5' 3 " fairly easily - used boom truck once 2-3 inches needed

Then welded splice in 24-inch - one pass - slight ridge on outside

- $\quad$ Continued Guzzling about 2 feet 


\section{DECEMBER 13,1995}

Boom truck $\neq 2-3$ inches

(Repair 1 -inch drill)

Dropped about 20 inches in CMP

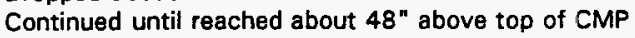

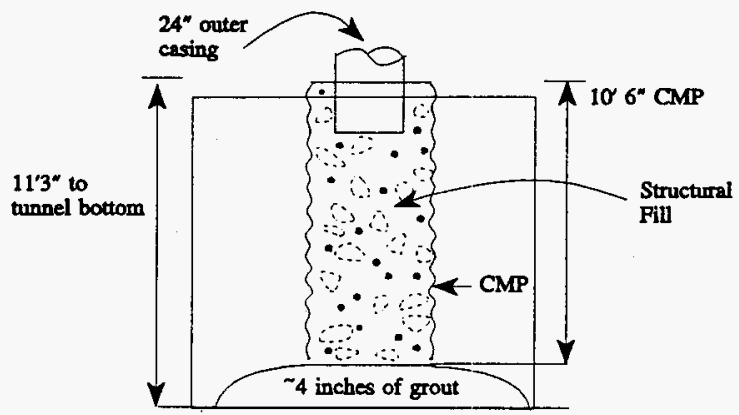

Excavate and Set 24" Casing in CMP

Approximately $7^{\prime} 2^{\prime \prime}$ in - $3^{\prime}$ to go; then difficult up and down with boom truck. In fact, even lost ground, $2-3$ inches

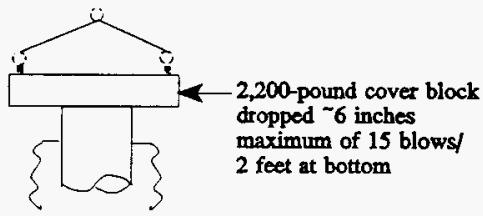

Started at 9 a.m.; finished at 11:30 a.m. 


\section{DECEMBER 14,1995}

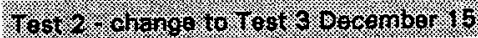

Set 18-inch diameter core for Test 2 (Change to Test 3)

Use 5 Star Epoxy - 1 set

Move 24-inch diameter to new spot

Hilti down - on Friday

Lenny - use $1 / 2$ " diameter pipe for bit cooling water with holes, also use instead of rod

\section{DECEMBER 15,1995}

\section{Test 3. Two Stacked Cover Blocks}

Weld 1-inch diameter drill - after machining

Finish Hilti down with 24-inch

Use only partial grout, not in center of inner casing, outside inner case only

No grout visible inside 18-inch inner casing, but no apparent leakage

1 -inch drill down total 12 to 13 inches

\section{0 lark agron watar test}

Started 1-inch drill at 1 p.m. At 1:42 p.m., down 9 inches. Until 3 p.m. checked wear and water occasionally. At end, seemed to slow down, but boring true. Heat up to $100^{\circ} \mathrm{F}$ on bit.

rpm $120-130$ - no down pressure 


\section{DECEMBER 18,1995}

\section{Test 2, Two Stacked Cover Blocks}

No work in morning - training for crew

30 minutes - 1 " drill 4 to $4-1 / 2$ inches

rpm $85-145$

Epoxy in at $12: 40$ to $12: 45$

$85-90 \mathrm{rpm}$

Core barrel drilling:

$12-13$ inches in $11 / 4$ hours

85-90 rpm

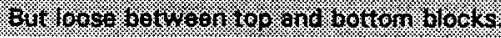

\section{DECEMBER 19,1995}

Started core barrel drilling at 8:05 a.m., about 8:30 began to bind up - up-and-down motion - blocks actually lifted - rod moved in top blocks.

Eventually freed up core barrel, but tooth was broken off.

Finished approximately 2 inches, but epoxy rod came loose. Epoxy mainly INSIDE pipe.

1-inch diameter hole Test 3. $40-45 \mathrm{~mm} \quad 130-140 \mathrm{rpm} \quad 4-1 / 2$ inches water in inner casing.

Move 10 inches deep - 6 inches into block.

Close end of $1 / 2$-inch diameter pipe - 3 holes for drill water - stingers with welding.

Set rod carefully - use hammer on rod to break up capsule and mix epoxy-about 2 p.m.

Set up for Test 4 - on slope, check. 


\section{DECEMBER 20,1995}

Tested $1 / 2$-inch diameter pipe into number 3 block - 950 pounds.

\section{Test 4, Sloped Cover Block}

Set up for drill with 18-inch diameter casing shoe on slope, use coupling. Fill between 18-inch and 24-inch with water. Recirculate total in 55 gallon - began losing water near end. Recovered about 40 gallons. Drill in about 6 inches.

Grout, WWF, and roofing paper came out easily at center, once cut through by the casing shoe.

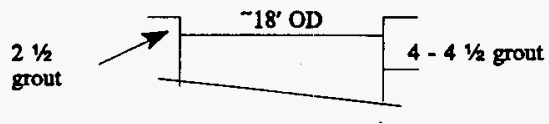

Tried 2-inch cracker jack bit - worked okay, but difficult to move drill head and hold to drill into grout that's as much as 4 inches thick on low side.

Then used ripper, noisy but effective. Began to score grout at upper side. Came out in chunks. Then used as ram down continued to chip away - effective. Used for about 30 minutes.

At end

\section{Remaining lip of roofing paper/WWF/grout}

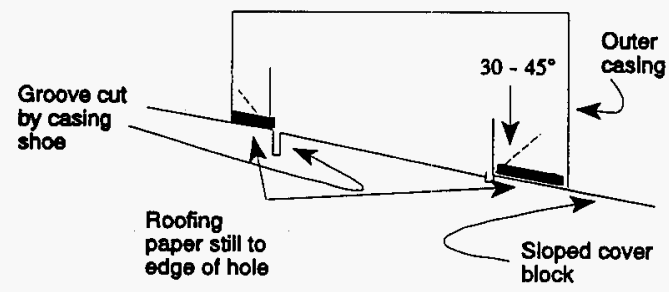




\section{DECEMBER 20, 1995 (continued)}

Then drill with 18 -inch shoe additional $1 / 4$ to $1 / 2$ inch deep shoe bound up - pulled block vertically - removed - no apparent bit damage

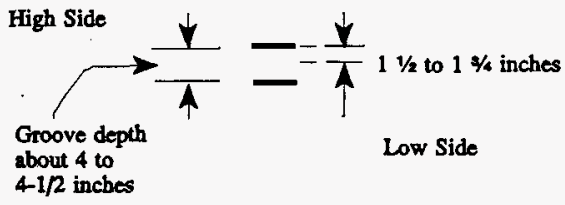

Put in 0.8 cubic feet of epoxy grout. Up and down with 18 -inch casing. Casing vertical - looks okay.

Finished grout at about 3 p.m.

DECEMBER 21, 1995

No work at site, training activities for drilling crew - put water in 18-inch riser 4 for water test.

\section{DECEMBER 22, 1995}

\section{Test 4, Sloped Cover Block}

1. No leakage in riser, Test 4.

2. Drilled about $10 \frac{1}{2}$ inches - 1 -inch drill in 23 minutes - just water in 18-inch.

3. Set epoxy - $1 / 2$-inch pipe.

4. Started drilling core barrel at about 1:05 p.m.

5. Drilled $60-70$ minutes - $1 / 2$-inch pipe broke off because of grout in center which had moved around in hole, broke away from hatch cover block.

6. Drilled to 9 inch of going through sloped cover block on high side.

7. Developed metered water flow for final coring at about $1 / 2 \mathrm{gal} / \mathrm{minute}$ 
DECEMBER 27,1995

Test 4, Sloped Cover Block

Cold morning. Heated water to start pumping. Pump at about $1 / 2$ gal/minute or less.

Start 8:13 a.m. to 9:35 a.m. broke through high side; low side about $1 \frac{1 / 2}{\text { inches of }}$ remaining concrete block.

90-100 rpm through in 8 minutes - core held in core barrel - core barrel hit holding bar at bottom - two teeth moved on core barrel - needed to be welded.

Hole finished - $14 \%$ inner diameter.

Set 12 -inch diameter riser with pipe insulation gasket installed around the bottom end.

Fill with $1 / 2$ gallon of Masterflow $928^{\mathrm{m}}$ - set 30 minutes then 0.8 cubic feet of 5 Star Epoxy ${ }^{\text {m }}$ grout.

Moved Guzzler.

Cut 18 -inch to length for B|G hole.

Weld in the morning.

\section{DECEMBER 28,1995}

\section{Test 5, Simulated Riser Installation in Soil Column}

1. Remove core barrel for repair

2. Set in top for 18 -inch shoe

3. Move Test 4 , empty pan $2 \frac{1}{2}$ inches, about 14 gallons, collect debris

4. Move in Test 3 block

5. Move rig to Test 5

6. Weld 18 -inch pipe extension to shoe and top coupling - total $152 \%$ " casing shoe/drill string length.

Start 1:24 pm

42-45 rpm

$5 \mathrm{r} / 2$ inches in 28 minutes $75 \mathrm{rpm}$ finish

7 inches in 42 minutes through grout and concrete

Complete cutting groove inner casing. 


\section{DECEMBER 29, 1995}

\section{Test 5 . Simulated Riser Installation in Soil Column}

1 to 2 inches of snow

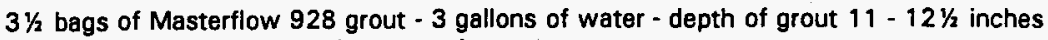
all around between inner and outer casing

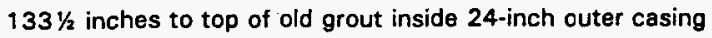

18 -inch cut $146 \%$ inches in a hole about $2 \%$ inches deep in tunnel bottom

Weight of bottom string 18 inches

$$
\begin{aligned}
& =\quad 1,100 \text { pounds } \\
& =\quad \frac{1,000 \text { pounds }}{2,100 \text { pounds }}
\end{aligned}
$$

Riser Fabrication

Cut and weld 12 -inch pipe to 13 - 6 length for riser, $12-11 \frac{1}{2}$

about 6 inches above inner casing

$$
1 ' 0
$$

$\frac{11-11 \%}{12-11 / 2}$

\section{Drill 1-inch Hole for Retention Pipe}

25 minutes to drill 1 -inch diameter hole by 6 inches deep in tunnel bottom

Set 2 tubes of epoxy in 1 -inch diameter hole

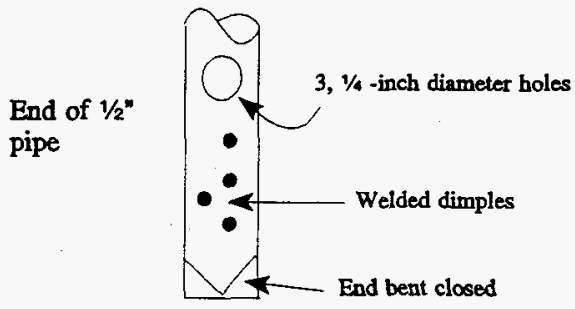




\section{JANUARY 2,1996}

\section{Test 5 , Simulated Riser Installation in Soil Column}

1. Measure down to water in 18-inch diameter casing, $134 \%$ at 8 a.m., same as 3 p.m. on $12 / 28$.

2. Pulled 700 pounds on pipe okay - pipe is off center at top - about 1 inch from one side.

3. Repaired core barrel arrived at 8:30 a.m. - put more weld on every tooth outside remeasure.

4. Cored 11 inches in 55 minutes about $50 \mathrm{gal}$ rpm 90-95 - empty out cooling water/cuttings with Guzzler - dropped bolt from centralizer, fished out with magnet.

5. Put glue on pipe insulation on 12 -inch riser - let set until January 3.

6. Stopped core with about 1 inch to go.

Put in about 5 gallons water, but actual total depth was 17 inches. Cut 6 inches additional in about 50 minutes - had to change and set up - ran out of travel on drilling drive.

7. Centering device not effective - core well off center. (NOTE: Possibly set too high on NWJ drill string. Needs to be right above core barrel for best results.)

8. Difficulty with removing core stuck inside core barrel - beat out with hammer.

9. $1 / 2$ inch diameter pipe held - gouge in one side of pipe due to rubbing by core barrel cap.

10. Set up to finish Test 3 . 


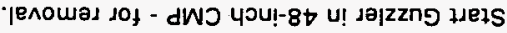

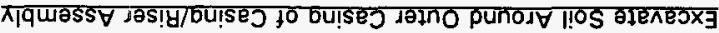

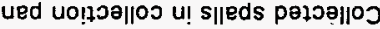

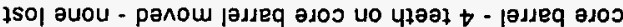

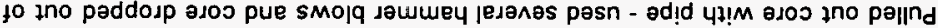

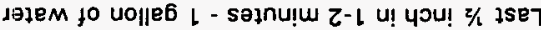

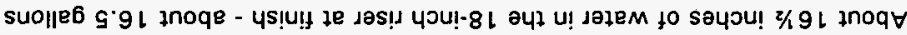

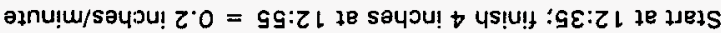
aınu!w/sayวu! $82 \cdot 0=$ salnu! $6 Z /$ seyวu! 8

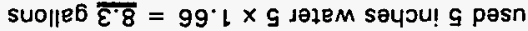

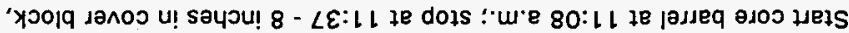

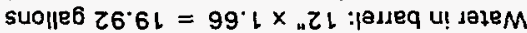
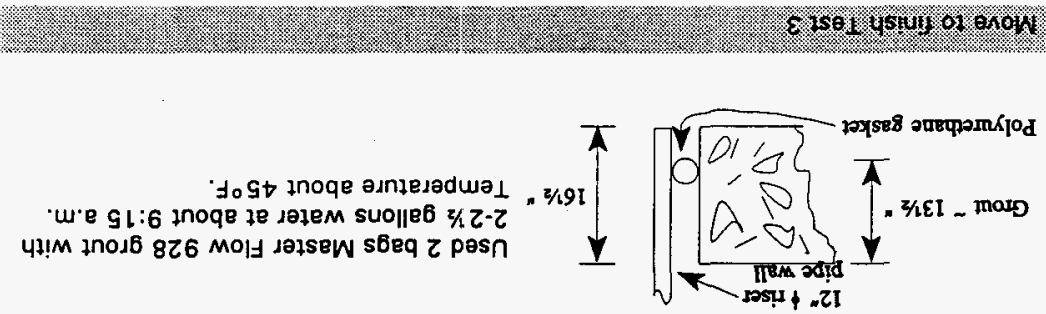

qejs to wołoq enoqe seyou!

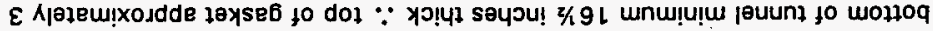

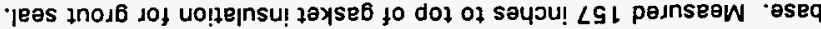

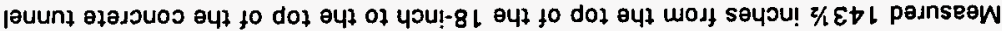

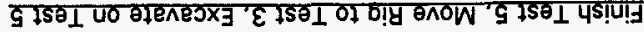




\section{JANUARY 4, 1996}

Test 5 , Simulated Riser Installation in Soil Column

9 a.m. $-83 \%$ inches from top of 12 -inch riser to water

Same as January 3 at 2:30 p.m.

Removal of riser/casing assembly with crane

Core barrel - single block moved - 4 others in a row close to coming off

SOLITION

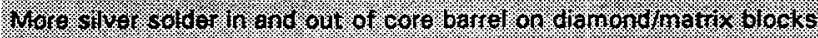

Pulled 12-inch riser - 2,000 pounds with Dymo at 10:05 a.m.; Dymo-USA-HW-477267; model WT-10, serial number 33075; Chatillon - Dymo 10000

Rest of day spent Guzzling dirt from inside CMP. pulling CMP and pulling 12, 18, and 24 inch pipes.

Pulled up horizontally - 2 directions with crane, pulled vertically with up to 13,000 pounds while beating top of 24 -inch with hammer. 12, 18, and 24 inch all came up - with slippage in grout.

\section{JANUARY 5,1996}

Record information, dimensions etc., for 12-18-24 assembly from Test 5 and photographs.

Photos of important drilling equipment.

Ensure all blocks and cores are on boom truck bed to take to yard.

\section{JANUARY 11,1996}

Placed steel cover plates over piping tunnel where cover blocks had been removed. 
WHC-SD-WM-ER-557, Rev. 0

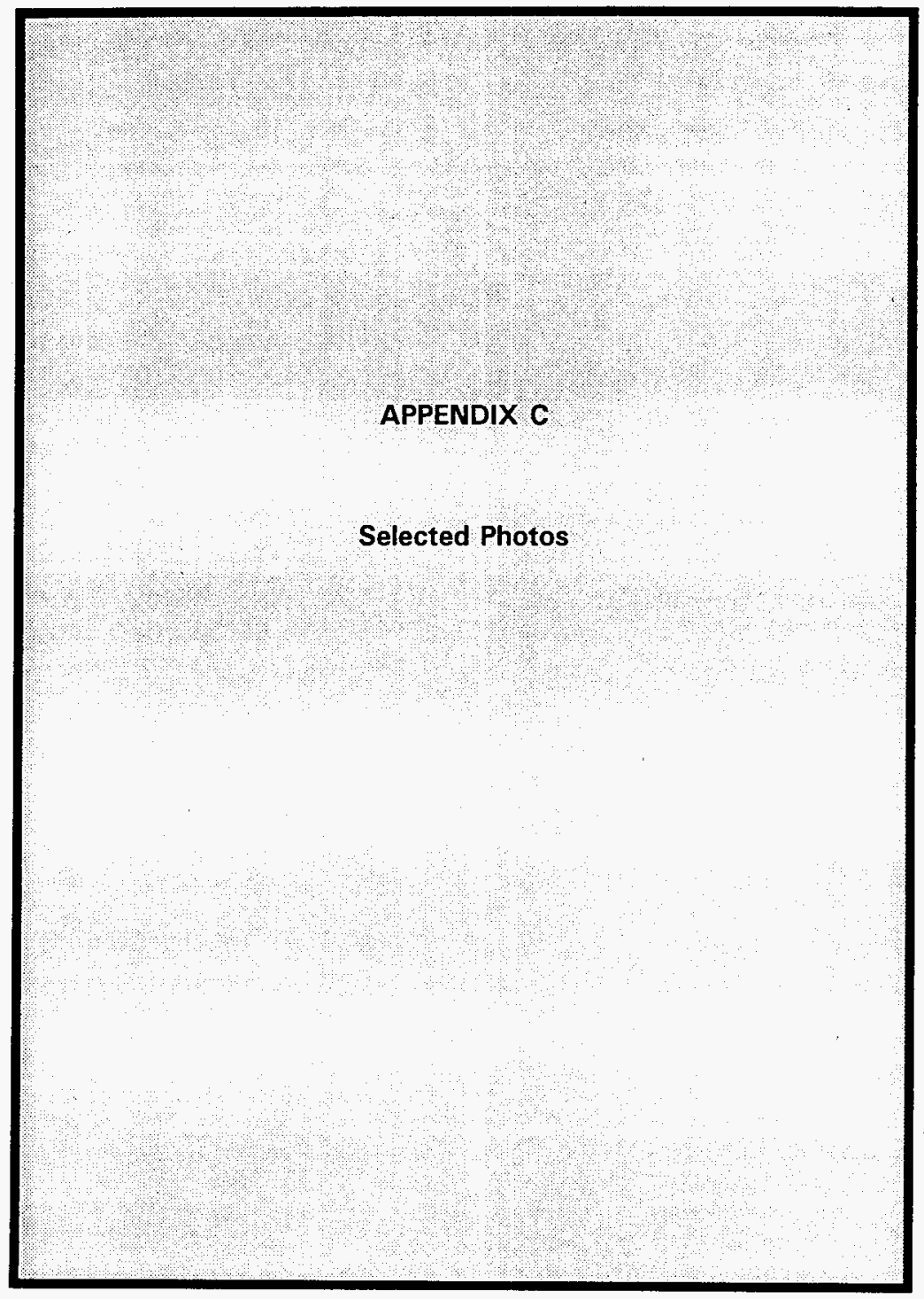

C-O 

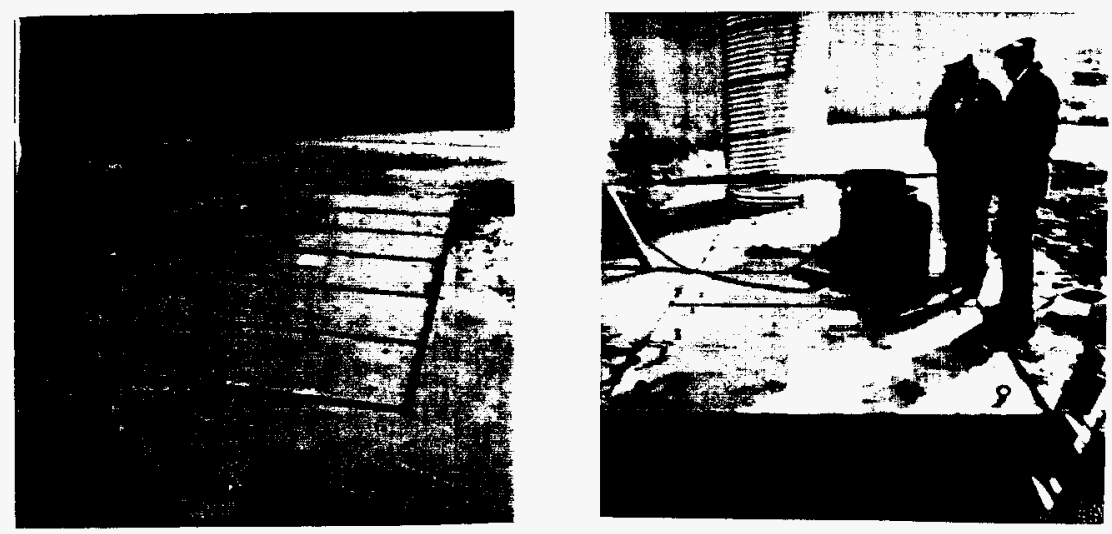

Photo 1. Six Hatch Cover Blocks on Piping Tunnel at $100-C$ Area
Photo 2. Cooling Water Reservoirs of Outer Casing Attached to Cover Blocks

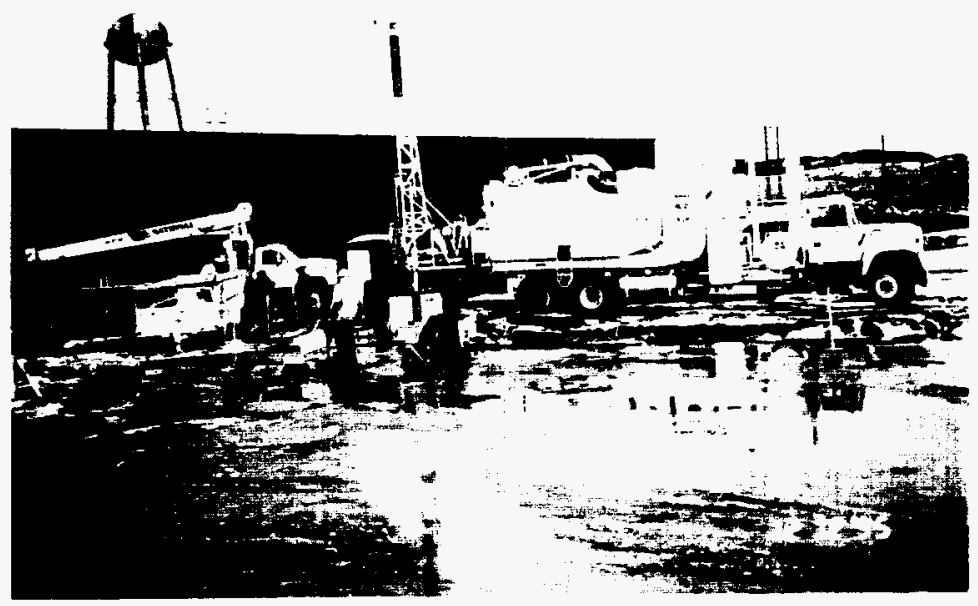

Photo 3. Major Pieces of Drilling Equipment at Test Site [From Left: Boom Truck, Drill Rig, and Vacuum Truck (Guzzler)] 


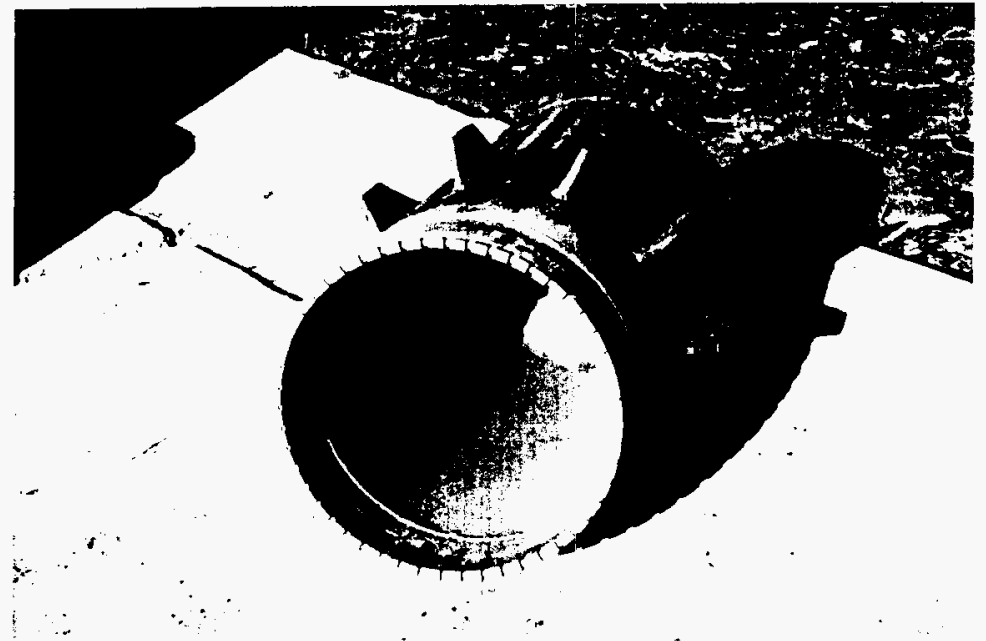

Photo 4. Casing Shoe Bit, $450 \mathrm{~mm}$ (18 inch) Diameter with 50 DiamondEmbedded Segments, $13 \mathrm{~mm}$ (1/2 inch) Wide Kerf, and Centralizer Vanes

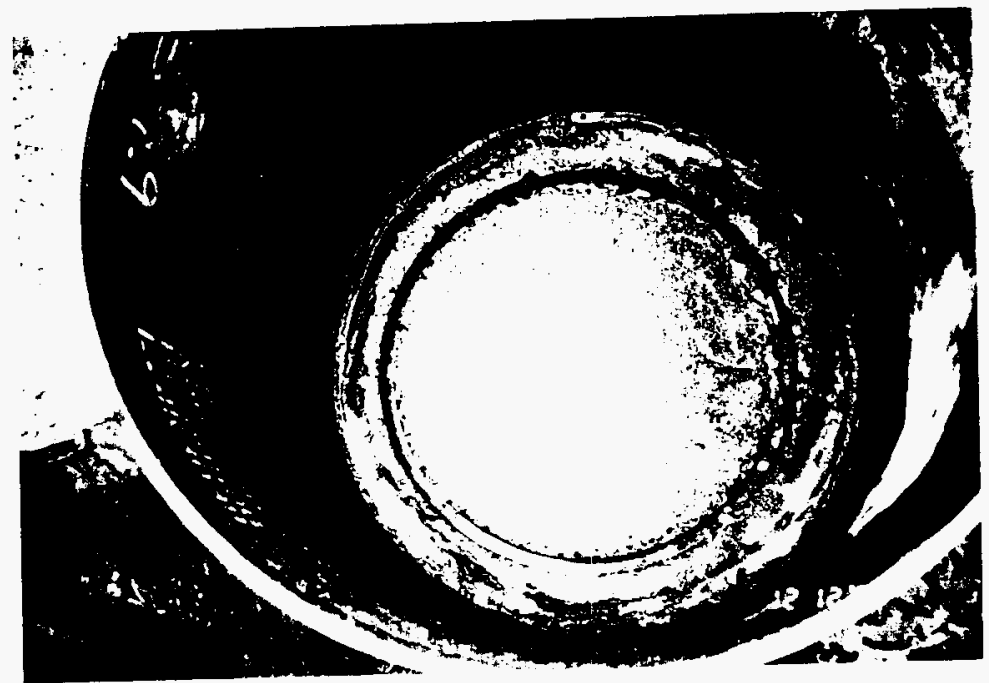

Photo 5. Groove Cut in Cover Block by Casing Shoe inside Outer Casing. The Bright Streak in the Groove is Rebar that Was Cut Away. 


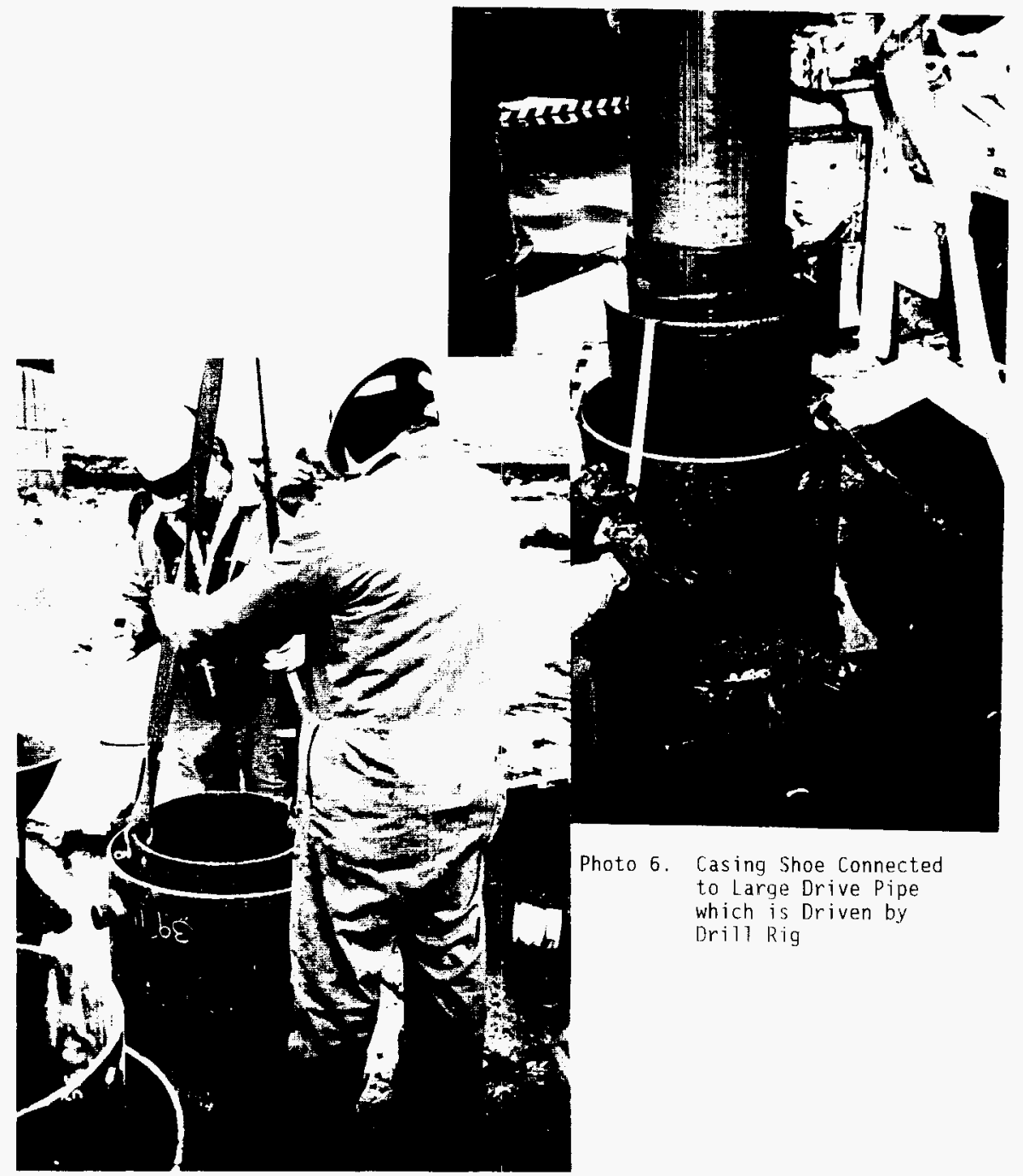

Photo 7. Setting Inner Casing in Groove in Cover Block with Grout 

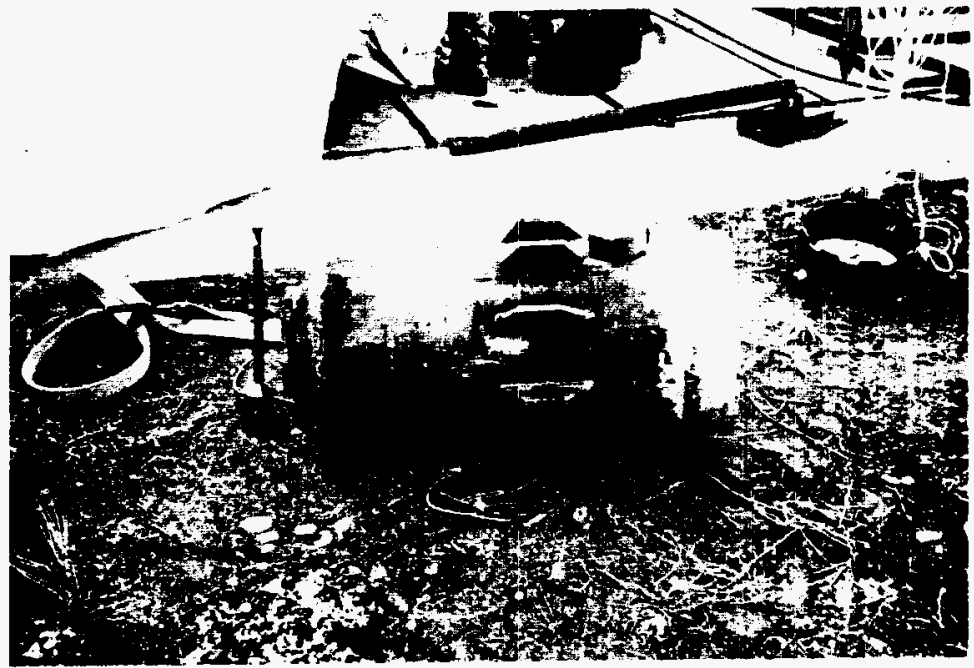

Photo 8. Casing Shoe with $25 \mathrm{~mm}$ (1 inch) Full Hole Drill Bit. Drive Coupling and NWJ Dri11 Rod in Background

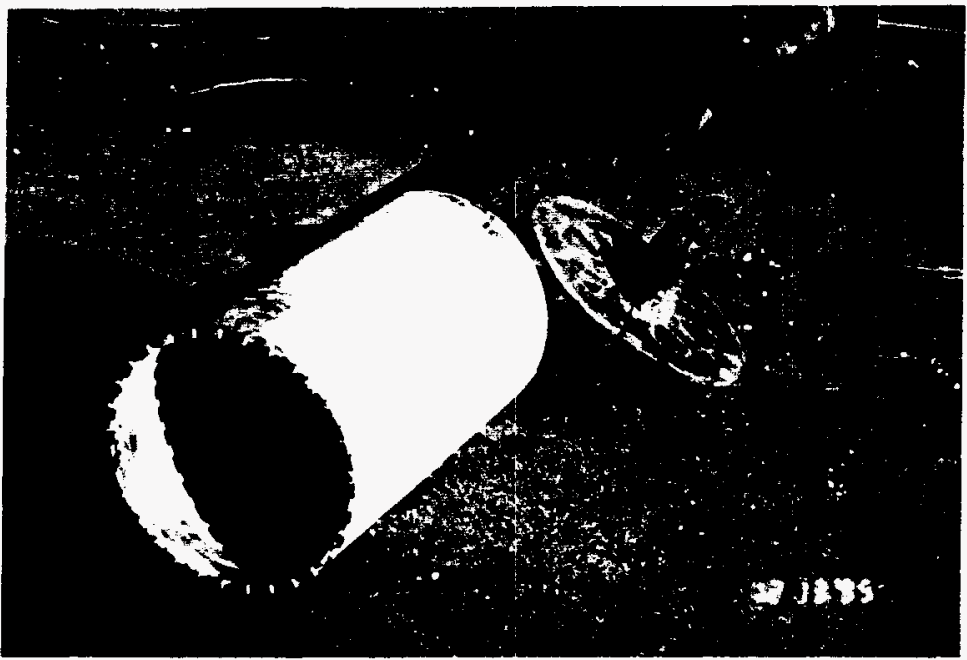

Photo 9. Core Barrel Bit, $368 \mathrm{~mm}$ (14.5 inch) in Diameter with 30 DiamondEmbedded Segments, $13 \mathrm{~mm}$ Wide Kerf. Centralizer for Mounting on the NWJ Dri11 Rod 
WHC-SD-WM-ER-557, Rev. 0

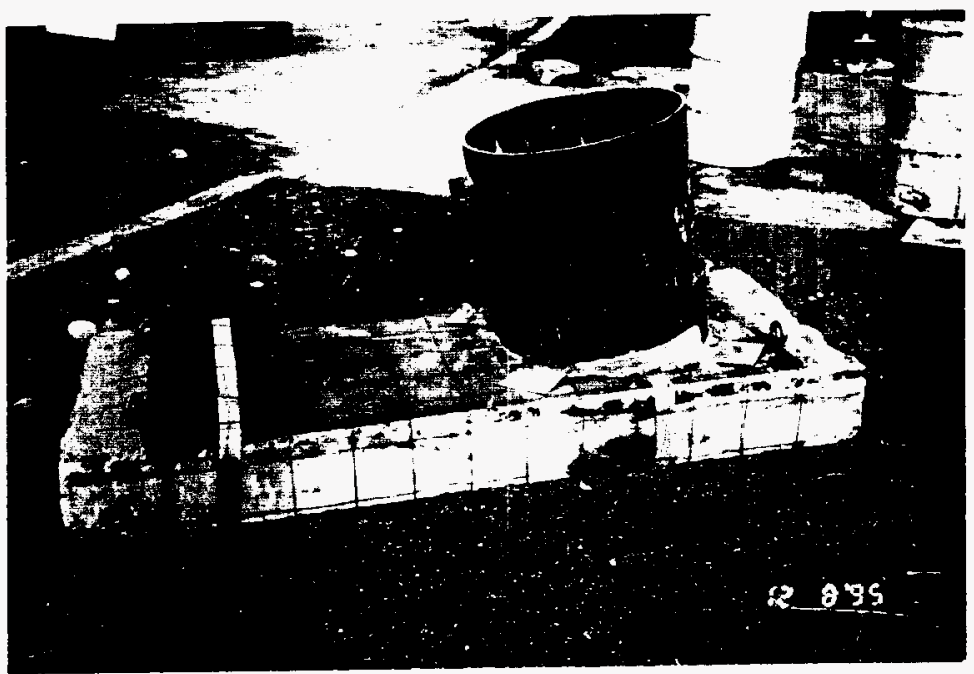

Photo 10. Outer Casing Set at a $10 \%$ Angle on a Layer of Grout, Welded Wire Fabric, and Felt Paper for sloped Cover Block Demonstration 4

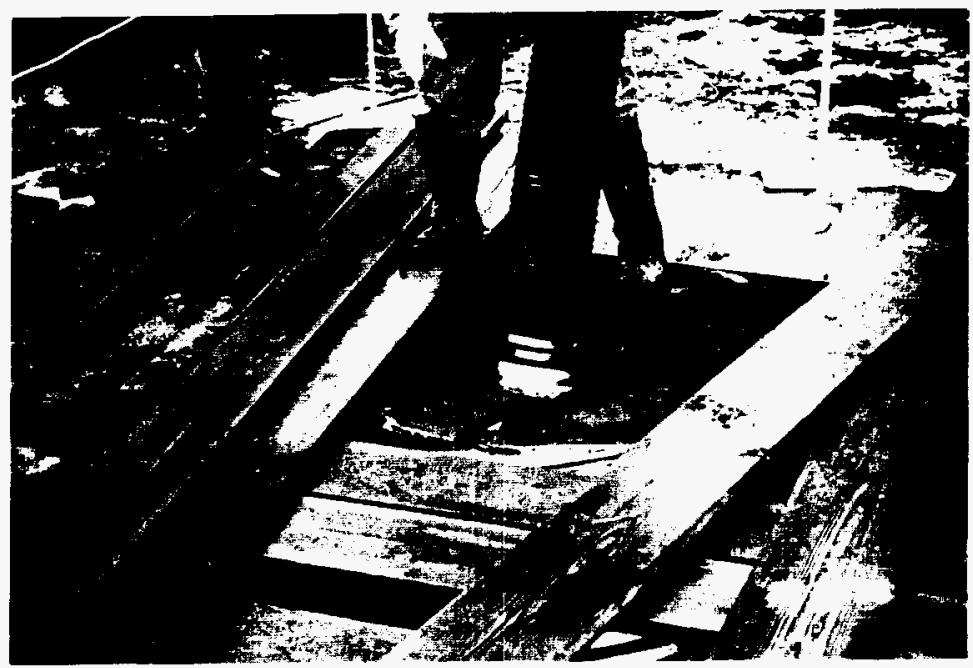

Photo 11. Starting Excavation in Compacted Soil Column with $150 \mathrm{~mm}$ (6 inch) Suction Hose from the Vacuum Truck (Guzzler) 
Uun $L O J \operatorname{loS} U !$

Gu!sej dazno butzas

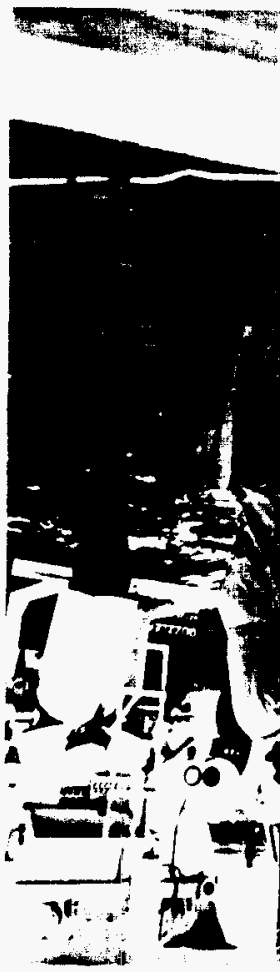

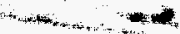
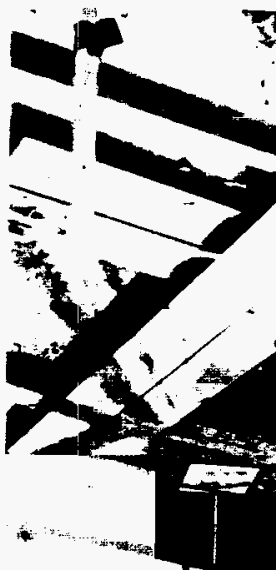

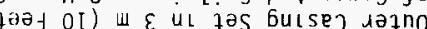

'El opoud
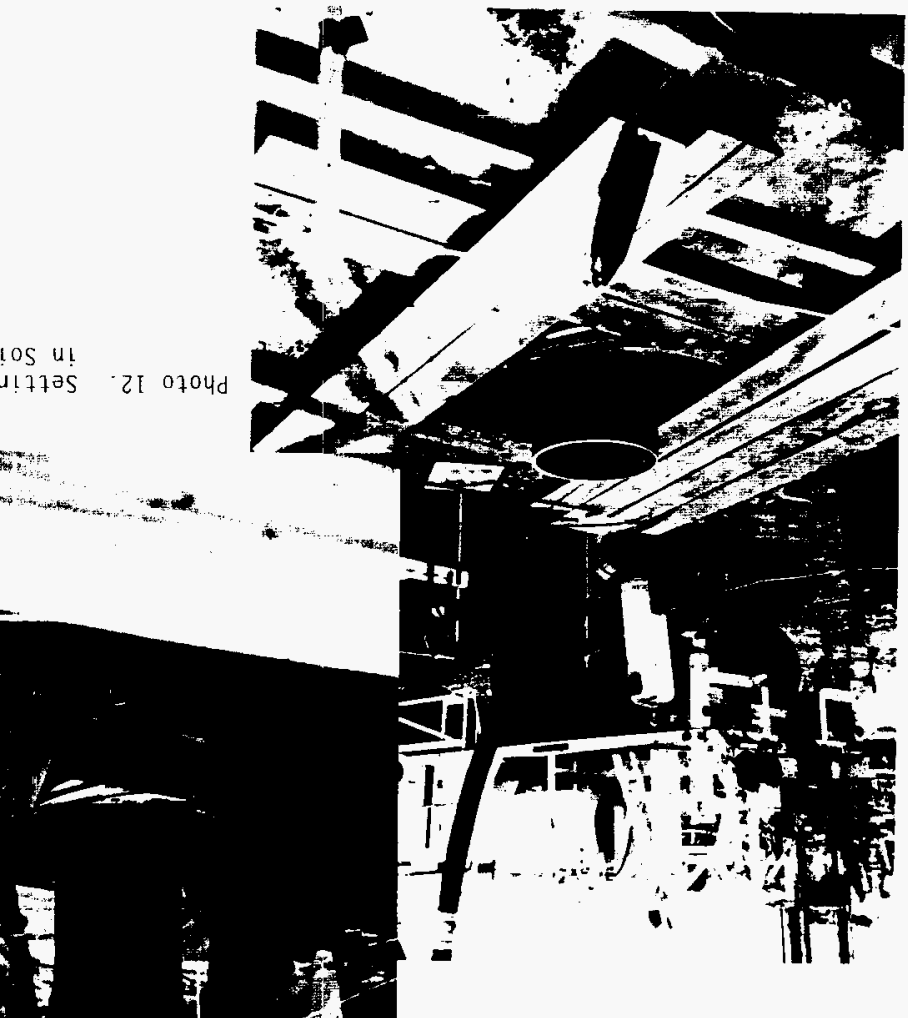

$+$

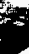




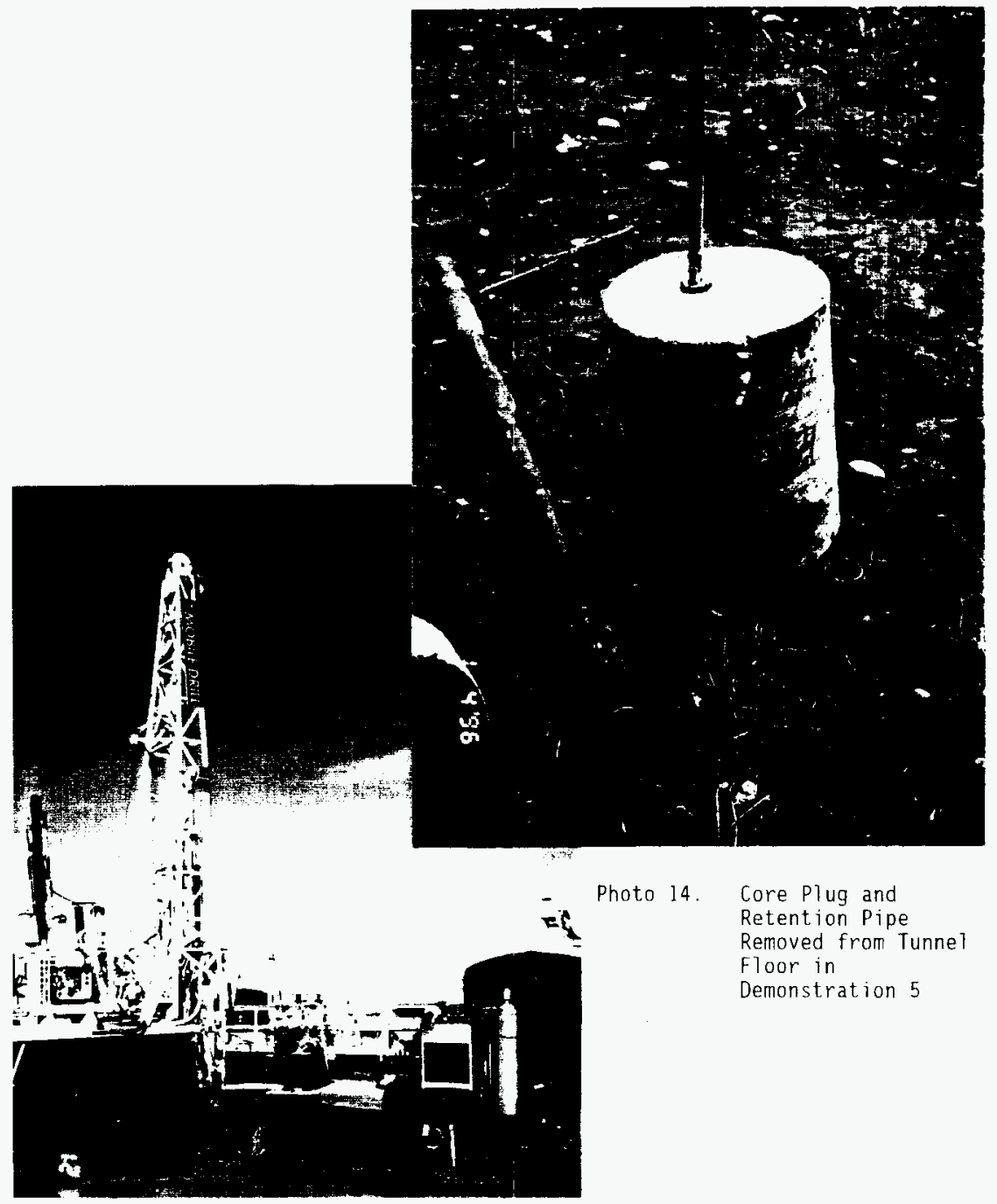

Photo 15. Rotary Drill Rig at Site.

NOTE: Auxillary Hoists on Mas: Used to Handle Drill String and Retain Core Plug 


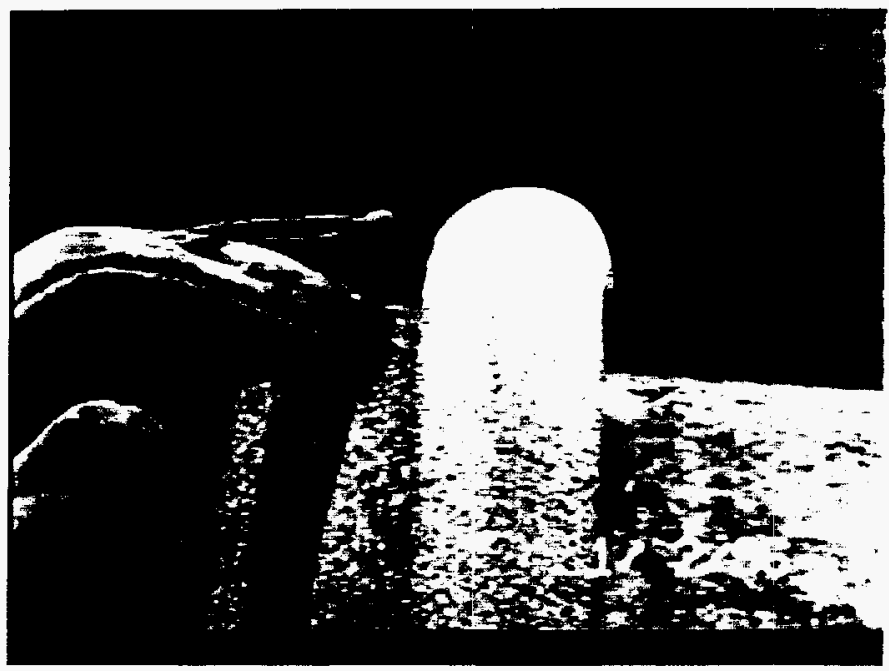

Photo 16. Installing Polyurethane Gasket around Lower End of $300 \mathrm{~mm}$ (12 inch) Diameter Riser for a Grout Seal
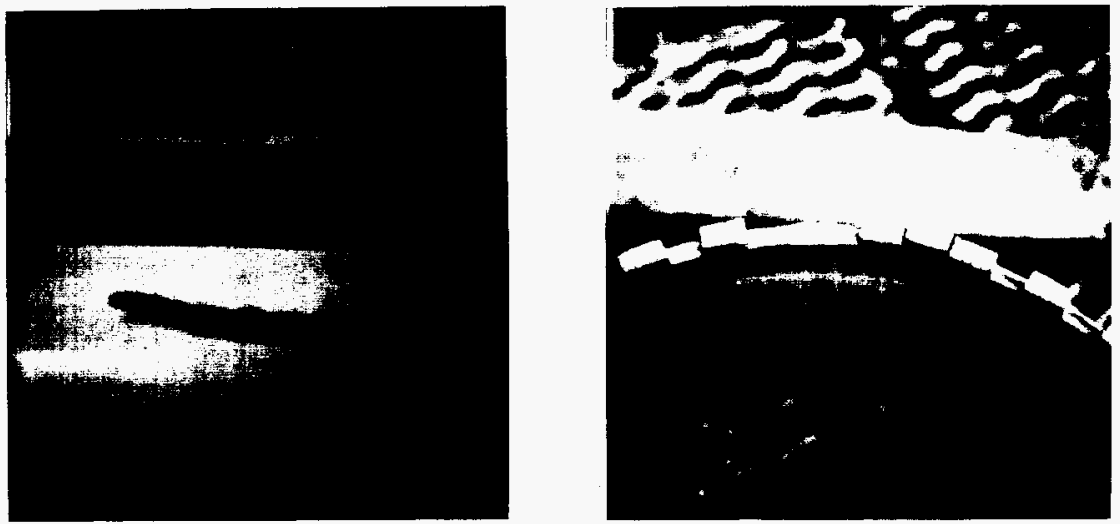

Photo 17. A Tangential Sliver of Reinforcement Bar that Came Loose from the Core Plug
Photo 18. Diamond-Embedded Segments Movement on Core Barrel Ring 


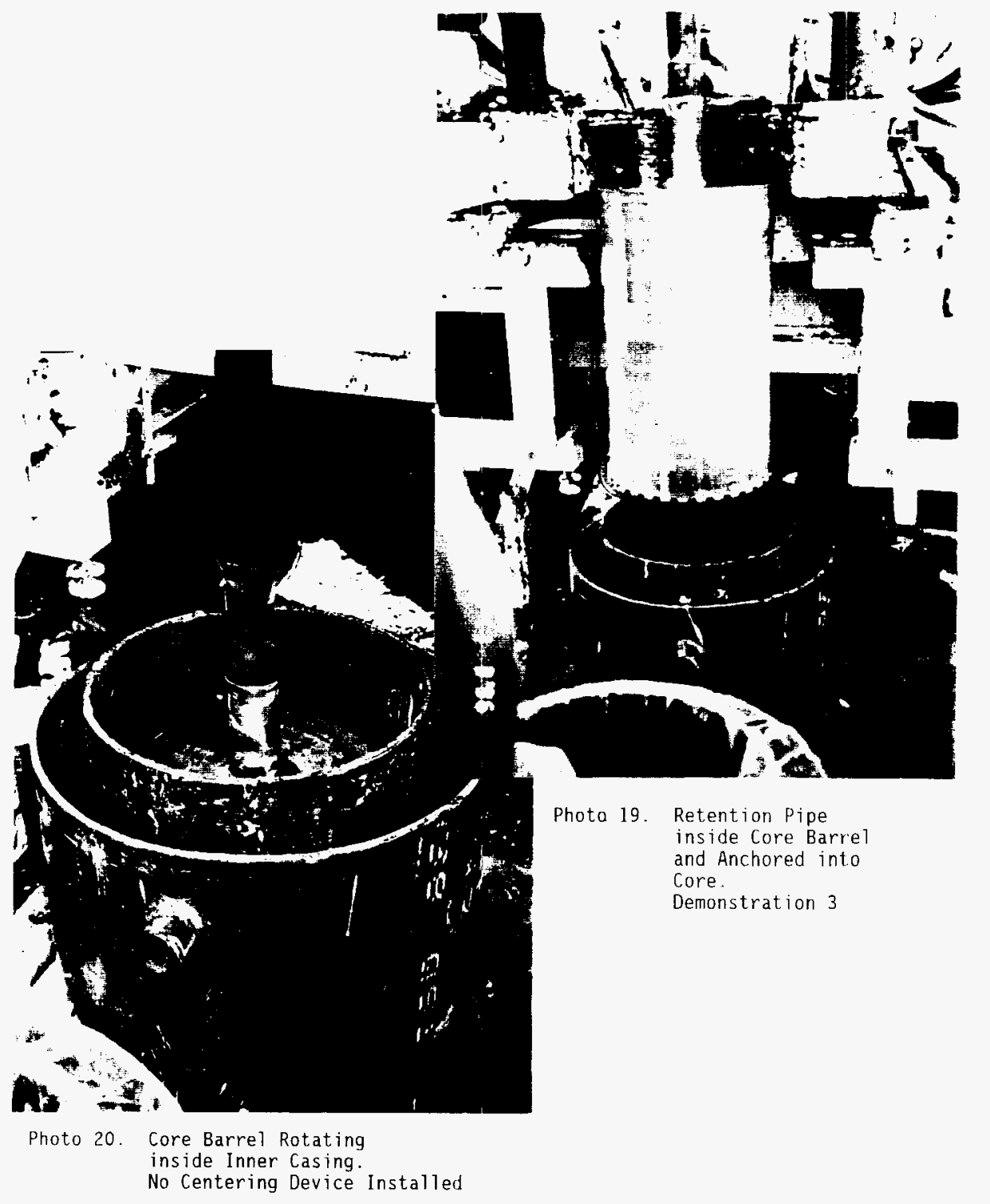




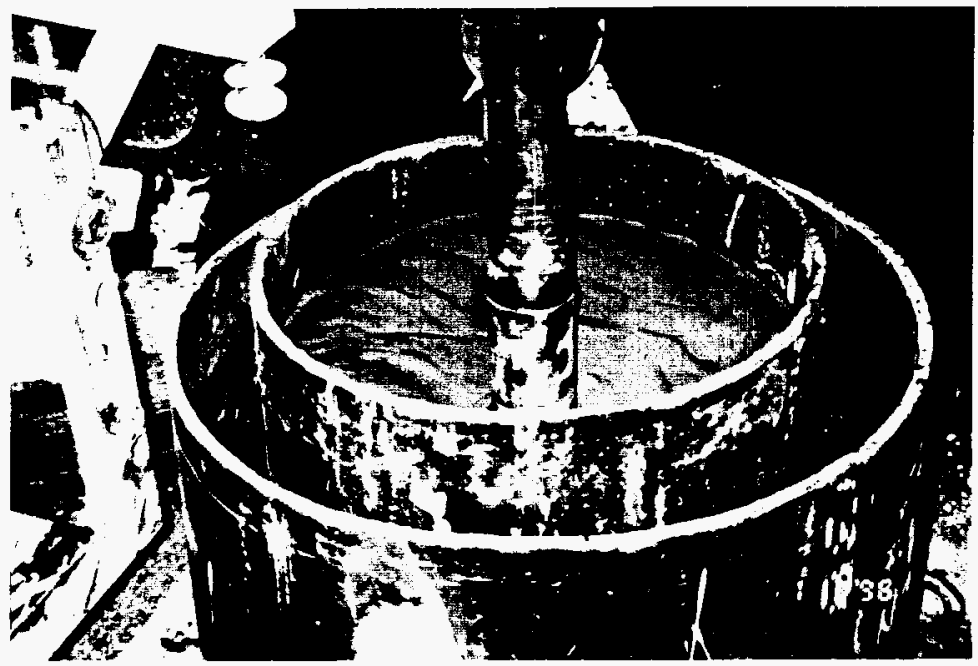

Photo 21. Cooling Water and Cuttings Circulating over Core Barrel in Demonstration 3

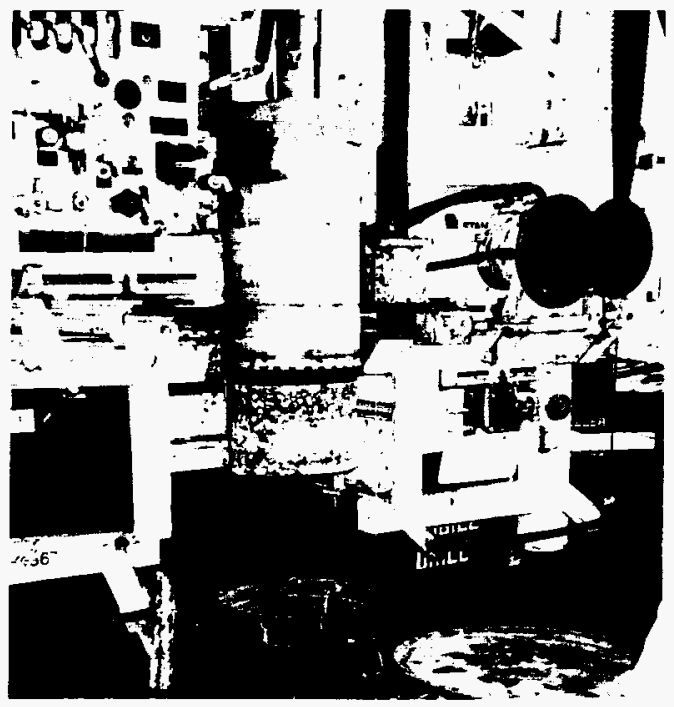

Photo 22. Core Plug being Removed from the Core Barrel and Cored Hole in Cover Block 
WHC-SD-WM-ER-557, Rev. O

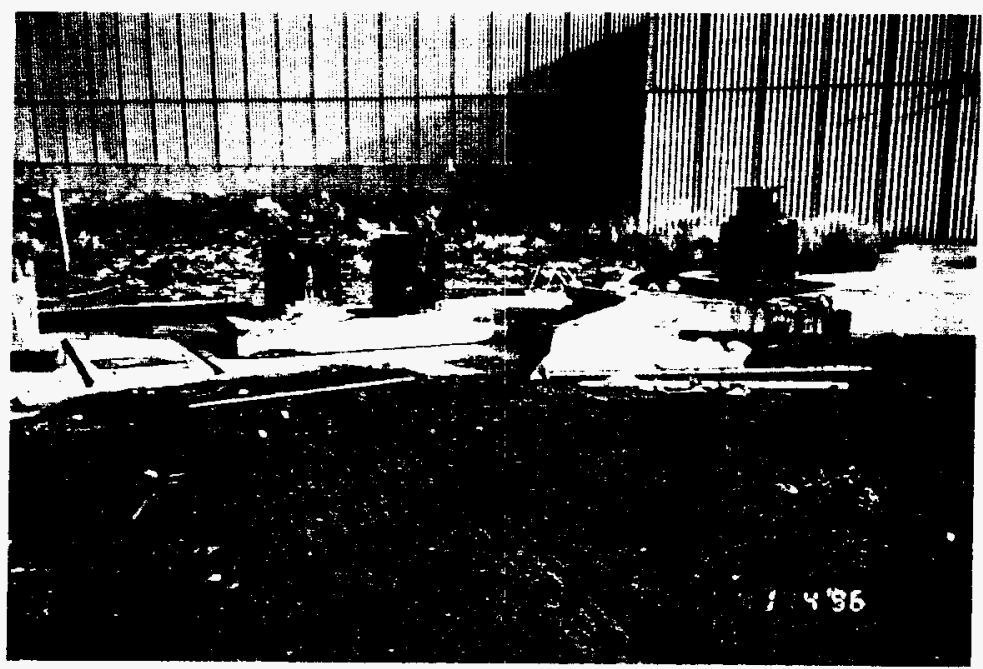

Photo 23. The $229 \mathrm{~mm}$ ( 9 inch) Cover Blocks used for the Preliminary Test through Demonstration 4 . The Block for Demonstration 4 is on the Right

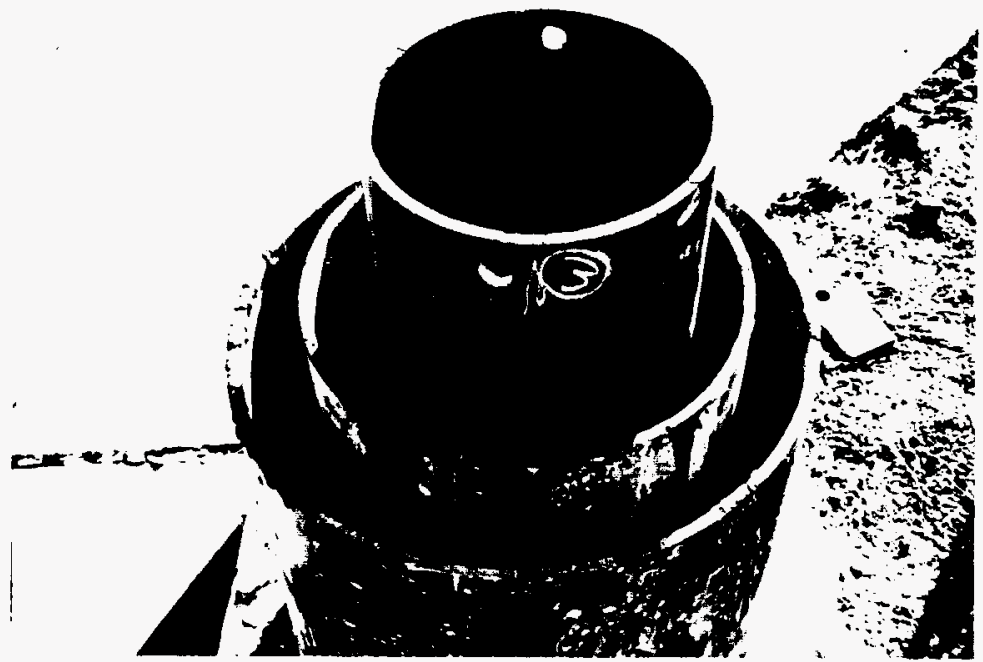

Photo 24. Water Leakage Test for Inner Casing to Riser for Demonstration 4 on Sloped Cover Block 


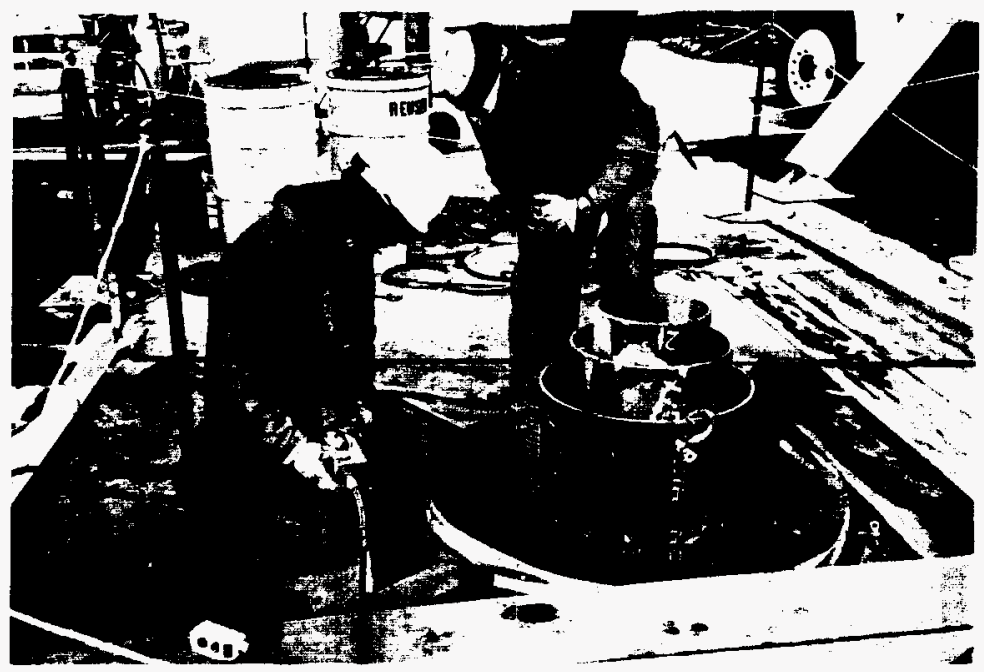

Photo 25. Compacted Soil around Outer Casing being Removed by Vacuum Hose

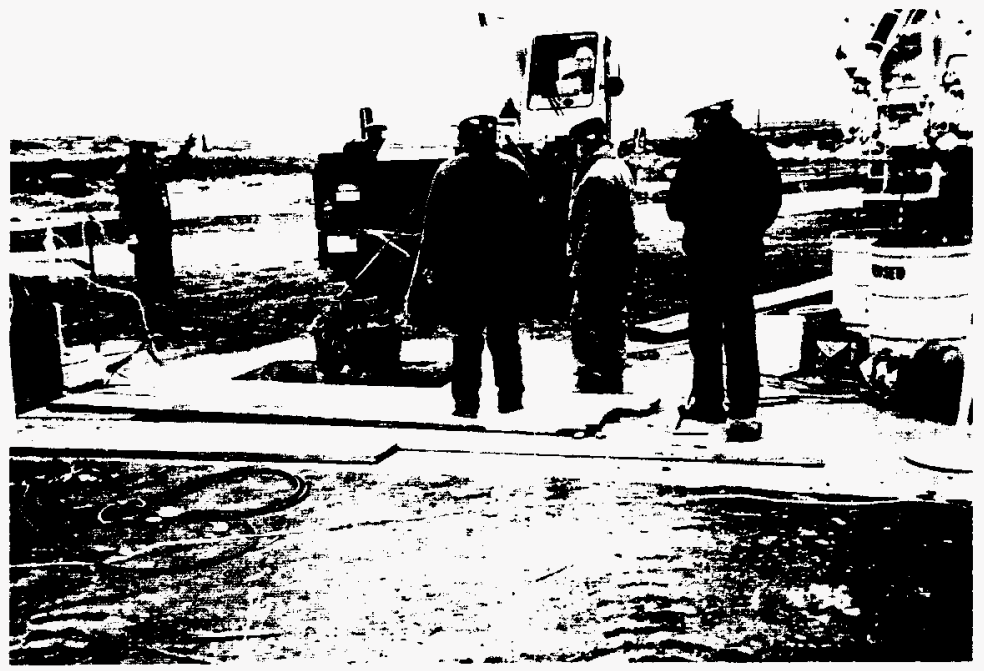

Photo 26. Loosening Riser/Casing Unit with a Pull from Crane 
Photo 27. Vertical Pull on Outer Casing, Test 5. Maximum Pull Approximately 13,000 Pounds
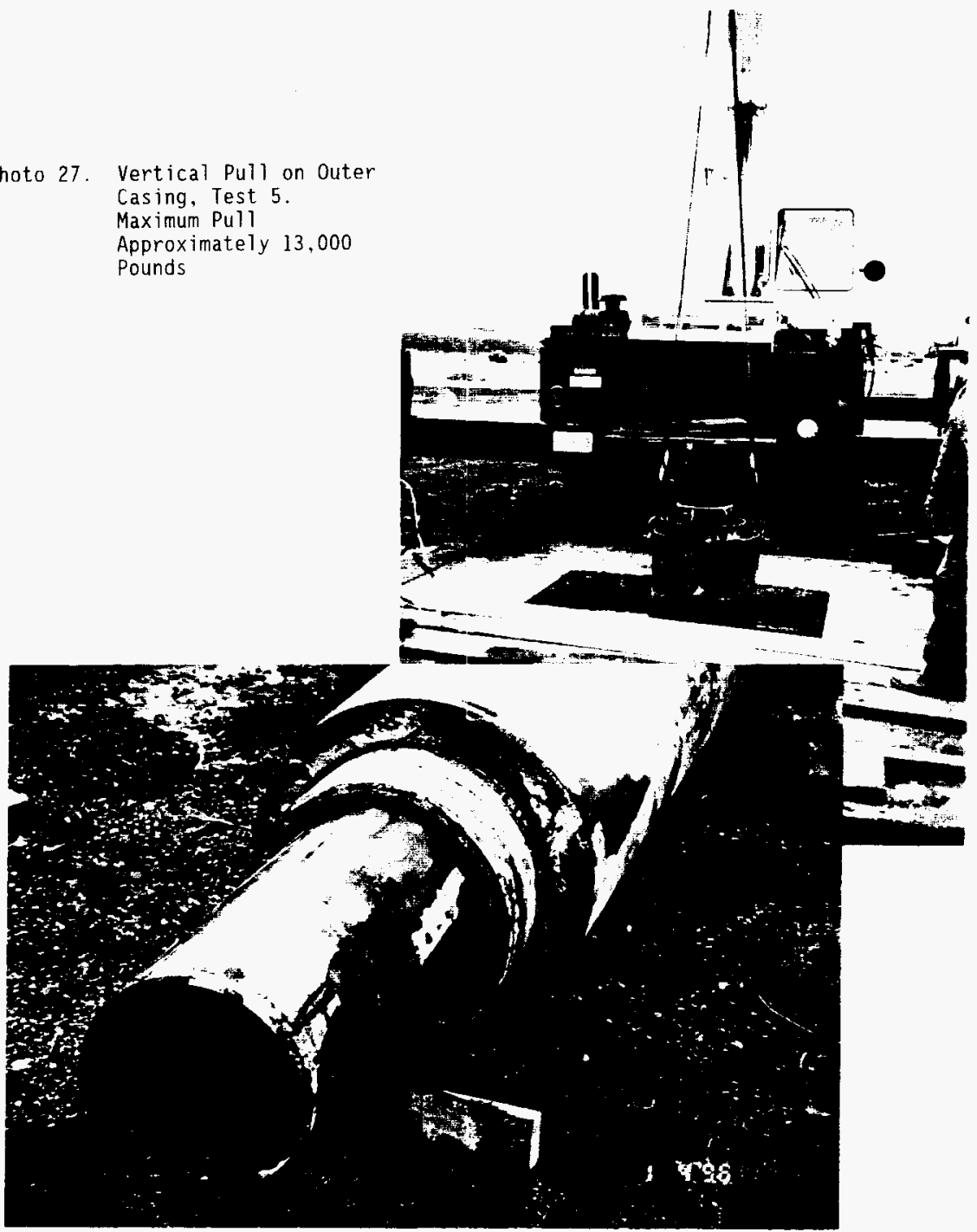

Photo 28. Test 5 Riser, Inner and Outer Casing after Pullout from Pipe Tunnel 
WHC-SD-WM-ER-557, Rev. O
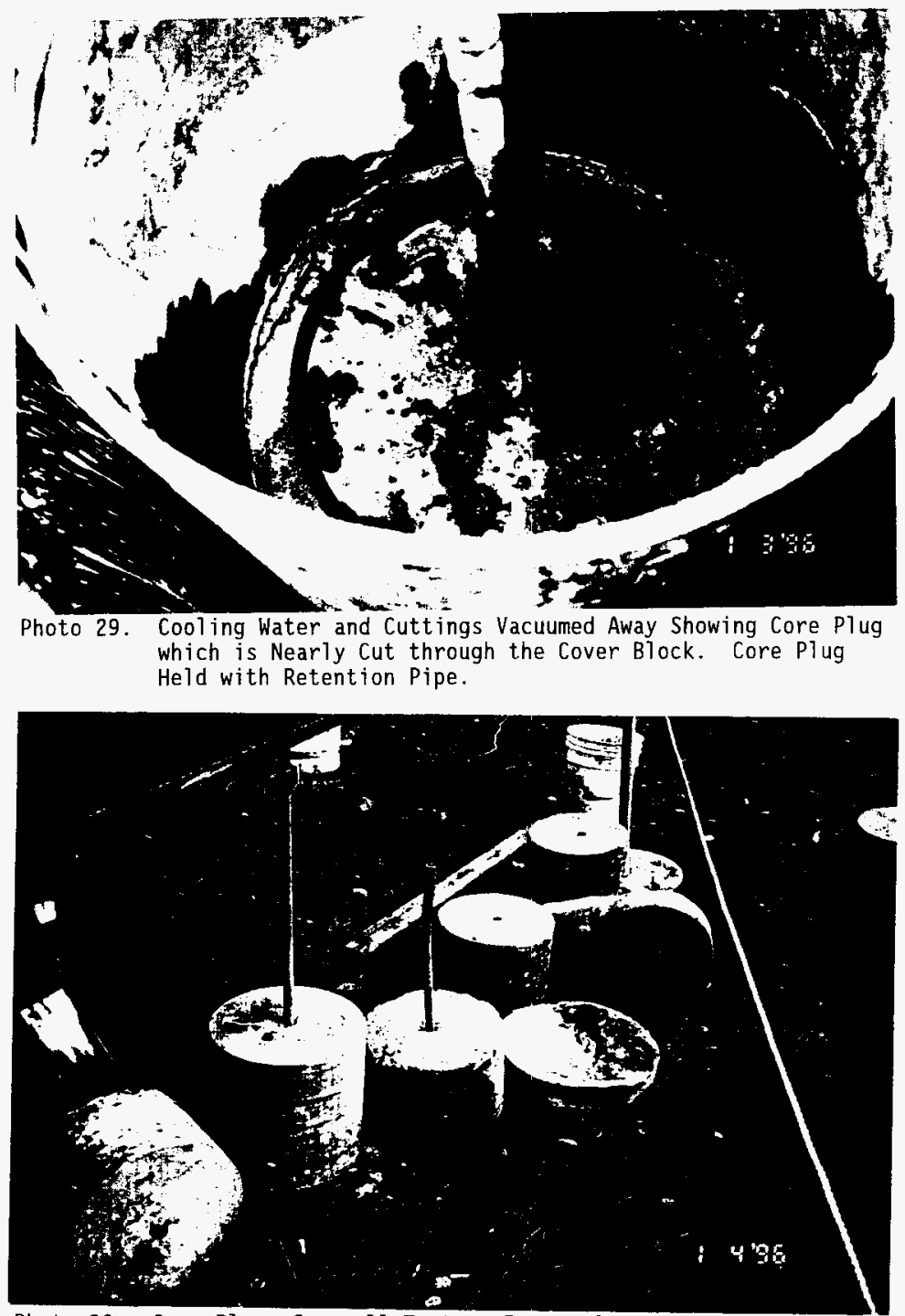

Photo 30. Core Plugs from all Tests. From Left: Preliminary Test, Demonstration $3,2,1,4$, and 5 on far Right. The Grout Cores in the Foreground are from the Tunnel Bottom in Demonstration 5, in the Preliminary Test and the WedgeShaped Piece from Demonstration 4. 


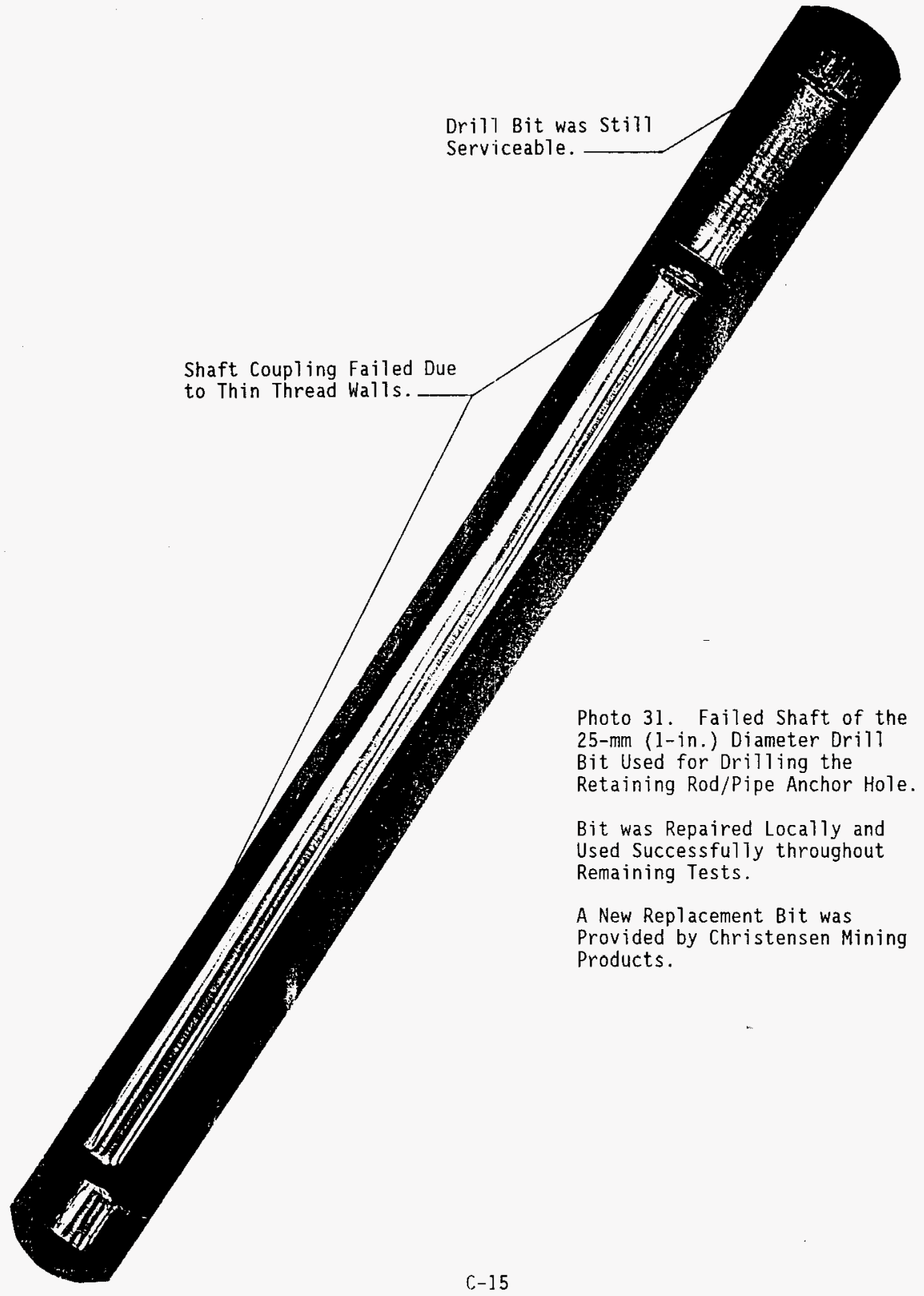




\section{APPENDIX D}

Equipment and Supplies 


\section{APPENDIX D \\ EQUIPMENT AND SUPPLIES LIST}

\section{EQUIPMENT AND SUPPLIES}

REMARKS

The drill rig, drill rod, chuck, and couplings were available on the Hanford Site.

\begin{tabular}{l|l} 
Mobil Drill $61 \mathrm{HD}$ rotary drill rig. & Has necessary speed and down pressure
\end{tabular} controls. Size is right for these types of drilling and dome-loading considerations.

NWJ taper thread drill rod.

Size adequate - disassembly relatively easy.

NWJ drive chuck.

For use with $25-\mathrm{mm}(1-$ in.) drill and core barrel.

Tightens well on NWJ drill rod and slips if drill

hits any obstruction.

Swivel top drive coupling.

Use for casing shoe and heavy drilling activities.

Centralizer - two-piece bolted unit to clamp around NWJ rod, $-432 \mathrm{~mm}$

(17 in.) OD to fit inside inner casing.

Simplify - possibly use a perforated plate welded to NW.J rod. Keep the centralizer close to the 25-mm bit and to the core barrel during drilling activities. Tack-weld all nuts to unit.

Cooling water and core retention pipe

Used galvanized standard wall pipe during test. - 13-mm (1/2-in.) galvanized standard pipe size to fit inside NWJ drill rod.

Light couplings - worked okay as long as the epoxy was set carefully and centered in hole in NWJ rod. Close end of pipe, add dimple welds for epcxy bond. Drilled holes for water flow to core barrel bit.

The following drill equipment was purchased from Christensen Mining Products

Subadaptor - NWJ drill rod to $25-\mathrm{mm}$ (1-in.) drill and core barrel rod connectors.

Casing shoe $-460 \mathrm{~mm}(18-1 / 8 \mathrm{in.}) \mathrm{OD}$ by $435 \mathrm{~mm}(17-1 / 8 \mathrm{in.})$ ID with 50 diamond-embedded segments, size $13 \mathrm{~mm}(1 / 2 \mathrm{in}$.) kerf by $19 \mathrm{~mm}$ (3/4 in.) by $7.9 \mathrm{~mm}(5 / 16 \mathrm{in.}$ ) thick.

Core barrel - 368-mm (14-1/2-in.) OD by $600-\mathrm{mm}$ (24-in.) barrel length with 30 diamond-embedded segments. Rod connection to accommodate a $76-\mathrm{mm}$ (3-in.) rod.
Worked well, except NWJ to core barrel adaptor belled out, but did not fail. The adapter must be torqued to manufacturer's specifications.

The $13 \mathrm{~mm}$ ( $1 / 2 \mathrm{in.)}$ kerf size was right for groovirg into concrete for receiving $450-\mathrm{mm}$ (18-in.) casing with a $10-\mathrm{mm}(3 / 8$-in.) wall. Several diamond/matrix blocks moved during Test 5. Increase size of silver solder fillet to weld blocks to raceway. The diamond segments can be replaced in the field. Ensure cooling water addition.

Size was right to accept $324-\mathrm{mm}(12-3 / 4-i n$ ) OD riser. Frovided ample annual space to ensure good grout seal. Blocks moved. Increase welds as with casing shoe. Ensure cooling water addition. 


\begin{tabular}{|c|c|}
\hline EQUIPMENT AND SUPPLIES & REMARKS \\
\hline $\begin{array}{l}\text { Small diamond bit }-25 \mathrm{~mm}(1 \mathrm{in} .) \text { OD } \\
\text { full hole bit with } 406-\mathrm{mm}(16-\mathrm{in} .) \\
\text { makeup shank to accommodate a } \\
76-\mathrm{mm} \text { (3-in.) rod. }\end{array}$ & $\begin{array}{l}\text { First bit broke in two places, construction was } \\
\text { too light. Bit was repaired and worked okay, but } \\
\text { cooling water orifice was restricted. New bit } \\
\text { was of better construction. }\end{array}$ \\
\hline $\begin{array}{l}\text { Cracker jack carbide bit }-48-\mathrm{mm} \\
\text { (1.89-in.) OD full hole bit with } 76-\mathrm{mm} \\
\text { (3-in.) shank to accommodate a } \\
76-\mathrm{mm}(3-i n .) \text { rod. }\end{array}$ & $\begin{array}{l}\text { Limited use one test to remove grout, WWF and } \\
\text { building paper. Worked, but not necessary if } \\
\text { casing shoe advances far enough into sound } \\
\text { concrete for good grout seal. Leave grout WWF } \\
\text { and building paper as is. }\end{array}$ \\
\hline Water swivel for NWJ drill rod. & $\begin{array}{l}\text { Not ordered, but may be needed to provide } \\
\text { sufficient cooling water pressure for small } \\
\text { diamond bit. }\end{array}$ \\
\hline \multicolumn{2}{|c|}{ Construction equipment available on the Hanford Site. } \\
\hline $\begin{array}{l}\text { Vacuum Truck, Guzzler } \\
\text { Manufacturing, Inc. }\end{array}$ & $\begin{array}{l}\text { Worked well to excavate for outer casing. Also, } \\
\text { used to clean hole after drilling and before } \\
\text { grouting. Later used Guzzler on other jobs below } \\
25^{\circ} \mathrm{F} \text { - tended to plug even in dry soil at low } \\
\text { temperatures. }\end{array}$ \\
\hline $\begin{array}{l}\text { Portable welder, Lincoln } \\
\text { Manufacturing Company. }\end{array}$ & $\begin{array}{l}\text { For welding and for providing } 120 \text { Vac power for } \\
\text { pump and instruments. }\end{array}$ \\
\hline Boom truck or light crane. & $\begin{array}{l}\text { Used boom truck, which is a light crane mounted } \\
\text { on flatbed truck during test. Maximum load to } \\
\text { be lifted is approximately } 1,200 \mathrm{lb} \text {. Need crane } \\
\text { with enough capacity to lift this load at radius to } \\
\text { spread major equipment loads on dome. }\end{array}$ \\
\hline Vibrator for setting outer casing. & $\begin{array}{l}\text { Not used during test. Recommend to use } \\
\text { Cougar Rotary Drill Vibrator, Model HC } 3-3500 \text {. }\end{array}$ \\
\hline \multicolumn{2}{|c|}{ Supplies and instruments obtained for riser test activities. } \\
\hline $\begin{array}{l}\text { Epoxy capsules - Hilti HEA } 3 / 4 \text { in. } \\
\text { diameter by } 6-5 / 8 \text { in. long, Part } \\
\text { No. } 000668129\end{array}$ & $\begin{array}{l}\text { Glass capsule of epoxy worked well as long as } \\
\text { hole in sound concrete a minimum } 127 \mathrm{~mm} \\
\text { (5 in.) deep, clean, relatively dry, and contents of } \\
\text { capsule are mixed thoroughly. }\end{array}$ \\
\hline Grout - Masterflow 928 & $\begin{array}{l}\text { Nonshrink grout worked well. High early } \\
\text { strength. Flowable and pumpable. No leaks } \\
\text { upon curing. }\end{array}$ \\
\hline Grout - Five Star Epoxy & $\begin{array}{l}\text { A two-part epoxy grout. High strength, but not } \\
\text { flowable or pumpable as the Masterflow } 928 \text {. }\end{array}$ \\
\hline $\begin{array}{l}\text { Grout - Standard Type I and I| cement } \\
\text { grout. Ash Grove. }\end{array}$ & $\begin{array}{l}\text { Standard type of cement grout. Shrank upon } \\
\text { curing, causing leaks around inner casing. }\end{array}$ \\
\hline
\end{tabular}


WHC-SD-WM-ER-557, Rev. O

\begin{tabular}{|l|l|}
\hline \multicolumn{1}{|c|}{ EQUIPMENT AND SUPPLIES } & \multicolumn{1}{c|}{ REMARKS } \\
\hline $\begin{array}{l}\text { Water pump - electric, 120 Vac, } \\
\text { Little Giant Water Wizard 25-mm } \\
(1 \text {-in.) outlet. }\end{array}$ & $\begin{array}{l}\text { Worked well immersed in water in 208-L (55-gal) } \\
\text { drum. Right size, easy to control with ball valve. }\end{array}$ \\
\hline Flow meter. & $\begin{array}{l}\text { Not used for test, but needed for risers in tanks. } \\
\text { Simple meter, 0.25 to } 5 \text { gpm range with } \\
\text { totalizer. For raw water addition, not } \\
\text { recirculation. }\end{array}$ \\
\hline RPM meter, Ameter - Model 1726 & $\begin{array}{l}\text { Hand held. Quick check to establish rotation } \\
\text { range of drill bits. }\end{array}$ \\
\hline $\begin{array}{l}\text { Riser gasket - used polyurethane pipe } \\
\text { insulation for 25-mm (1-in.) standard } \\
\text { pipe. }\end{array}$ & $\begin{array}{l}\text { Could use flat sheets about 25 mm (1 in.) thick. } \\
\text { Connect with adhesive and plastic ties to riser. }\end{array}$ \\
\hline
\end{tabular}




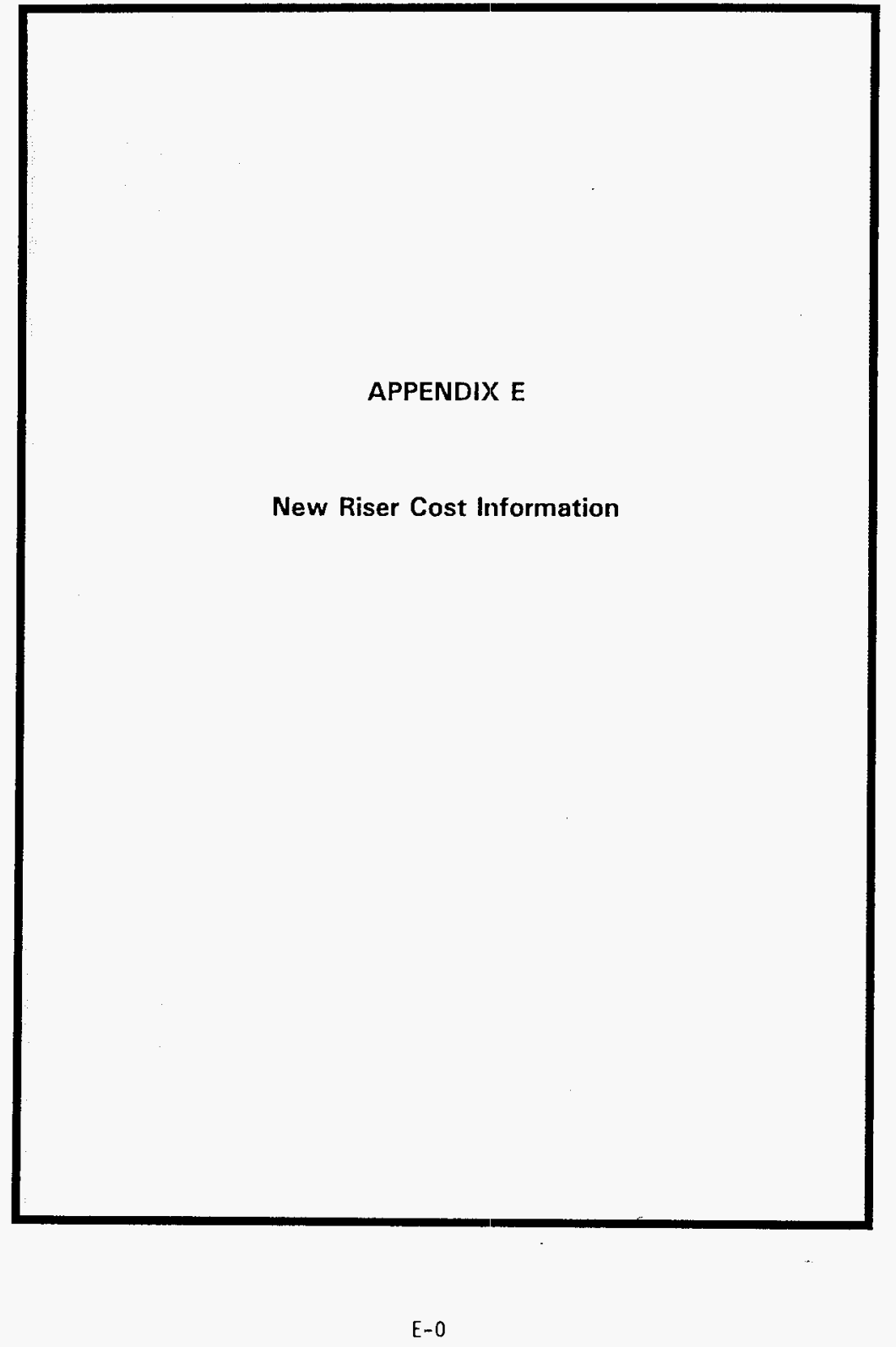




\section{NEW RISER COST INFORMATION}

Appendix $E$ includes cost information of first-time, generic costs to be allocated among all risers, and specific costs to install each riser.

The cost information listed in Table E-1 is taken from the following sources:

Reference 1 Taken from a Westinghouse Hanford Company draft cost estimate for Tank 241-C-103. A $30 \%$ contingency is applied.

Reference 2 Obtained from a telephone conversation with N. A. Homan (Westinghouse Hanford Compan'y) and R. L. Ackerman (ICF Kaiser Hanford Company).

Reference 3 Provided by Westinghouse Hanford Company

Reference 4 Provided by ICF Kaiser Hanford Company.

Reference 5 Provided by ICF Kaiser Hanford Company Engineering.

Reference 6 Provided by ICF Kaiser Hanford Company Engineering.

Reference 7 Provided by ICF Kaiser Hanford Company Engineering and Westinghouse Hanford Company based upon the cost estimate from the engineering study, current tank farm projects, and the experience gained in the simulated riser $^{-}$installation field activities. 


\section{COST INFORMATION}

The cost information consists of two components: first-time generic costs and actual costs to install each riser.

TABLE E-1

\begin{tabular}{|c|c|c|}
\hline \multicolumn{3}{|l|}{ COST INFORMATION } \\
\hline \multicolumn{3}{|c|}{ FIRST-TIME - GENERIC COSTS } \\
\hline & Dollar Amount & $\begin{array}{l}\text { Source } \\
\text { (Ref. No.) }\end{array}$ \\
\hline Environmental Assessment & 130,000 & 1 \\
\hline Operational Readiness Review & 90,000 & 1 \\
\hline Air Permits & 170,000 & 2 \\
\hline Safety Analysis & 150,000 & 3 \\
\hline Procedures & 50,000 & 4 \\
\hline Advanced Engineering & 95,000 & 5 \\
\hline Fabricate Exhauster & 100,000 & 6 \\
\hline TOTAL & $\$ 785,000$ & \\
\hline \multicolumn{3}{|c|}{ ACTUAL RISER INSTALLATION } \\
\hline Riser Installation & 220.000 & 7 \\
\hline $\begin{array}{l}\text { ADD Allowance Envelope, Environmental Assessment, Air } \\
\text { Permits, Safety Analysis for each specific riser }\end{array}$ & 30,000 & \\
\hline TOTAL & $\$ 250,000$ & \\
\hline \multicolumn{3}{|c|}{ NEW RISER INSTALLATION COST } \\
\hline First-time - Generic Cost & $\$ 785,000$ & \\
\hline Actual Riser Instaliation Cost & $\$ 250,000$ & \\
\hline TOTAL & $\$ 1,035,000$ & \\
\hline
\end{tabular}




\section{REFERENCE 2}

\section{AIR PERMITS}

The following air permits information was obtained during an April 12, 1996, telephone conversation between Richard L. Ackerman, ICF KH, and Nancy A. Homan, WHC.

1. R. L. Ackerman stated that the 1994 estimate for obtaining air permits was $\$ 220,000$.

2. N. A. Homan said that the process for obtaining air permits had been streamlined and can be done in-house, saving at least $\$ 50,000$.

3. R. L. Ackerman described the concept to N. A. Homan that the exhauster on the tank would be used only for several hours before the risers could be installed.

4. While Item 3 may simplify the permitting process, $N$. A. Homan suggested that the original value of $\$ 220,000$ less $\$ 50,000$ or $\$ 170,000$ be used for a conservative estimate. Also, the $\$ 170,000$ should cover permitting of the Guzzler, if it is not already permitted. 


\section{REFERENCE 3}

\section{RISER INSTALLATION SAFETY ANALYSIS COST INFORMATION}

The following assumptions and cost information is made for performing a safety analysis of an actual riser instaliation.

\section{Assumptions}

- Westinghouse Hanford Company (or main contractor) will perform the safety assessment.

- The riser installation project does not pay for any review time after the peer/project review.

\section{Estimate}

\begin{tabular}{|c|c|c|c|}
\hline Task & Personnel/Time Required & Rate & Total \\
\hline \multirow{2}{*}{$\begin{array}{l}\text { Hazardous } \\
\text { Operations }\end{array}$} & 10 people, 4 days (meetings) & $320 \mathrm{hrs} \times 80$ & 25,600 \\
\hline & 1 person, 2 weeks (report preparation) & $80 \mathrm{hrs} \times 50$ & 4,000 \\
\hline \multirow[t]{8}{*}{$\begin{array}{l}\text { Safety } \\
\text { Assessment }\end{array}$} & $\begin{array}{l}1 \text { person, } 6 \text { months (document } \\
\text { preparation) }\end{array}$ & $1,040 \mathrm{hrs} \times 50$ & 52,000 \\
\hline & 6 people, 5 days (peer review) & $240 \times 80$ & 19,200 \\
\hline & 2 people, 5 days (project review) & $80 \mathrm{hrs} \times 80$ & 6,400 \\
\hline & $\begin{array}{l}1 \text { person, } 1 \text { month (incorporate } \\
\text { comments) }\end{array}$ & $160 \times 50$ & 8,000 \\
\hline & & 1,920 Hours & \multirow{2}{*}{$\begin{array}{r}\$ 115.200 \\
\times 1.3 \\
\end{array}$} \\
\hline & Contingency $30 \%)$ & 576 Hours & \\
\hline & TOTAL & 2,496 & $\$ 149,760$ \\
\hline & ROUNDING & & $\$ 150,000$ \\
\hline
\end{tabular}




\section{REFERENCE 4}

\section{PREPARE PROCEDURES}

An estimate to prepare the procedures for conducting an actual riser instaliation is shown below. See Appendix $G$ for an outline of the procedures required.

\begin{tabular}{|r|c|c|c|}
\hline \multicolumn{1}{|c|}{ TASK } & HOURS & RATE & TOTAL \$\$ \\
\hline Draft procedures (includes review and approval) & 320 & 80 & 25,600 \\
\hline $\begin{array}{l}\text { Document preparation (includes incorporation of fina! } \\
\text { comments) }\end{array}$ & 250 & 50 & $\frac{12,500}{38,100}$ \\
\hline Add 30\% contingency & & & $\begin{array}{c}\times 1.3 \\
\$ 49,530\end{array}$ \\
\hline Rolunding & & & $\$ 50,000$ \\
\hline
\end{tabular}




\section{REFERENCE: 5}

\section{ADVANCED ENGINEERING}

Cost information for performing the engineering involved in preparing the casings, risers, special equipment for an actual riser installation, and performing the structural analysis of a tank dome are shown below.

1. Design Engineering
a. Drawings and specifications - fabricate casings and risers
b. Drawings and specifications - special equipment
c. Equipment list
d. As-build - riser installation

\begin{tabular}{|l|c|c|c|}
\hline \multicolumn{1}{|c|}{ PERSONNEL } & HOURS & RATE & TOTAL \$\$ \\
\hline Engineer & 240 & 80 & 19,200 \\
\hline Designer & 240 & 65 & 15,600 \\
\hline & & & 34,800 \\
\hline Add 30\% Contingency & & & $\times 1.3$ \\
\hline Rounding & & & $\$ 45,240$ \\
\hline
\end{tabular}

2. Structural Analysis of Dome

\begin{tabular}{|r|c|c|c|}
\hline \multicolumn{1}{|c|}{ PERSONNEL } & HOURS & RATE & TOTAL \$\$ \\
\hline Engineer & 480 & 80 & 38,400 \\
\hline Add 30\% Contingency & & & $\times 9.3$ \\
& & & $\$ 49,920$ \\
\hline Rounding & & & $\$ 50,000$ \\
\hline
\end{tabular}


REFERENCE 6

\section{EXHAUSTER REQUIREMENTS}

The volume of water and concrete chunks (estimated to be less than $5 \mathrm{gal}$ and $2 \mathrm{lb}$. respectively) expected to fall into a SST as the core barrel breaks through the dome is not significant. The hole to receive the new riser in the dome will be open a short time (estimated at less than 2 hours) before the new riser is grouted into place. Therefore. an exhauster required to ventilate the dome does not need to be elaborate. With minor modifications, an existing exhauster can be used; therefore, the $\$ 100,000$ allowance should be adequate. 
WHC-SD-WM-ER-557, Rev. O

REFERENCE 7

COST INFORMATION - RISER INSTALLATION

\begin{tabular}{|c|c|c|c|c|}
\hline TASK & CREW SIZE & DAYS & RATE & $\begin{array}{c}\text { TOTAL } \\
\text { (\$) }\end{array}$ \\
\hline Offsite fabrication, special equipment & 2 & 10 & 45 & 7,200 \\
\hline Fabricate casings, risers (OA) & 3 & 8 & 45 & 8,640 \\
\hline Mobilize - move to site & 6 & 6 & 45 & 12,960 \\
\hline Set outer casing & 15 & 4 & 45 & 21,600 \\
\hline Set inner casing through riser & 15 & 10 & 45 & 54,000 \\
\hline Pour slab - riser at grade & 8 & 2 & 45 & 5.760 \\
\hline Demobilize & 6 & 6 & 45 & 12,960 \\
\hline Superintendent & & 25 & 75 & 15,000 \\
\hline SUBTOTAL & \multicolumn{4}{|c|}{$\$ 138,120$} \\
\hline \multicolumn{5}{|l|}{ EOUIPMENT RENTAL } \\
\hline Small crane & & & & 1,500 \\
\hline Drill rig & & & & 1,200 \\
\hline Guzzler & & & & 1,000 \\
\hline Miscellaneous (welder, grout pump, etc.) & & & & 800 \\
\hline SUBTOTAL. & \multicolumn{4}{|r|}{$\$ 4,500$} \\
\hline \multicolumn{5}{|l|}{ MATERIAL } \\
\hline Grout, $8 \mathrm{yd}^{3}(100)$ & & & & 800 \\
\hline 10-ft by 24 -in. casing & & & & 1.000 \\
\hline 10 -ft by 18 -in. casing & & & & 800 \\
\hline 10-ft by 12 -in. riser & & & & 1,000 \\
\hline Slab, $5 \mathrm{ft}^{2}$ by 6 in. - reinforced & & & & 600 \\
\hline SUBTOTAL & \multirow{2}{*}{\multicolumn{4}{|c|}{$\$ 146,820$}} \\
\hline TOTAL RISER INSTALLATION & & & & \\
\hline Add $50 \%$ contingency & \multicolumn{4}{|r|}{$\times 1.5$} \\
\hline TOTAL & \multicolumn{4}{|c|}{$\$ 220,230$} \\
\hline Rounding & \multicolumn{4}{|c|}{$\$ 220,000$} \\
\hline
\end{tabular}




\section{APPENDIX F}

New Riser Installation Schedule 


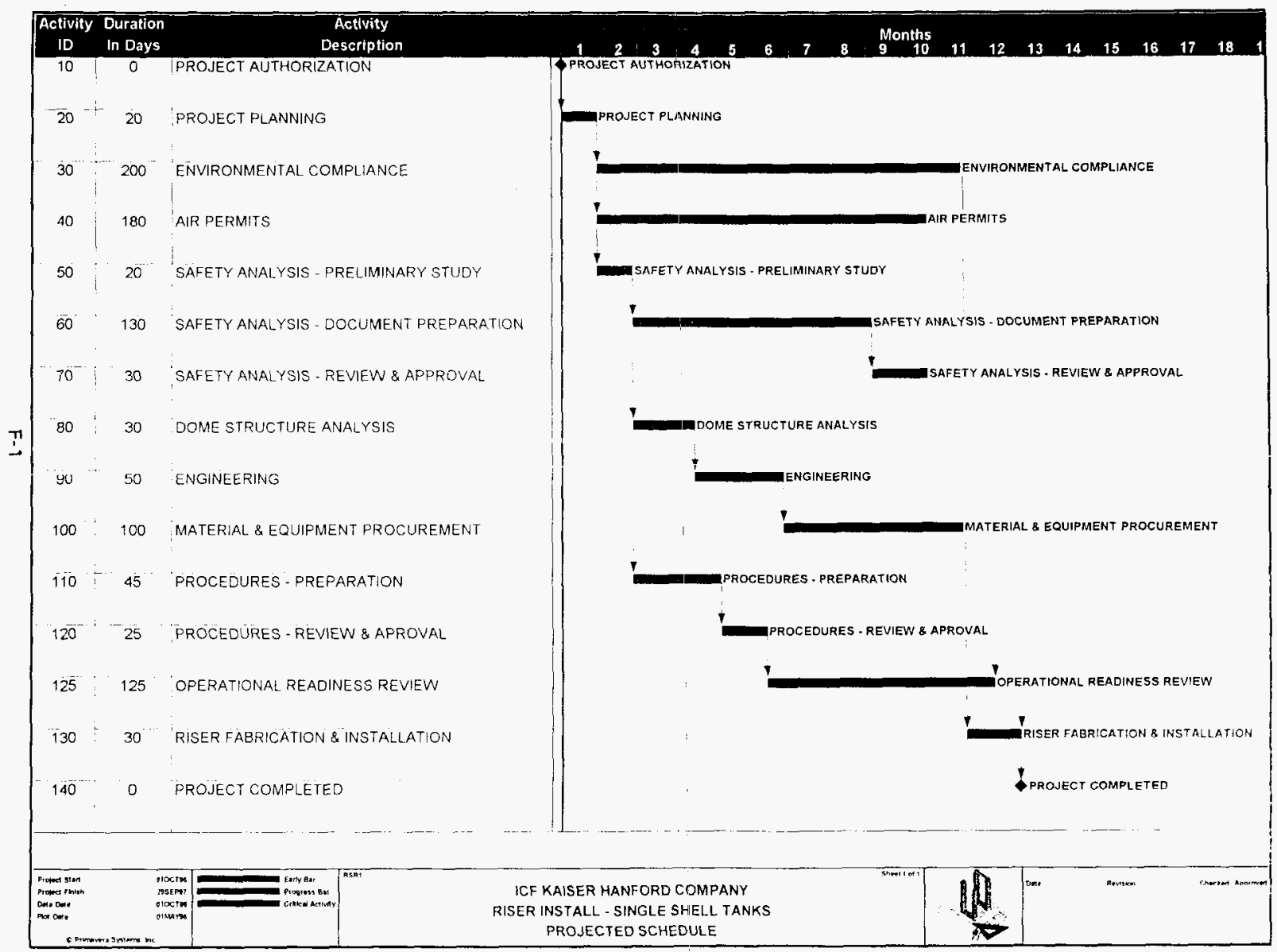




\section{APPENDIX G}

\section{Procedure Outline}




\section{PROCEDURE OUTLINE}

\section{A. PREPARATION}

1. Fabricate inner and outer casing, partially fabricate riser, and fabricate $15-m m(1 / 2-i n$.$) retention pipe assembly.$

2. Procure equipment - drill rig, drill bits, light crane, Guzzler, and miscellaneous equipment.

3. Fabricate casing shoe bits, centralizer device, and cooling water system.

4. Assemble drill team.

\section{B. SET OUTER CASING}

1. Choose riser location on SST - an alternate site may be required if a high level of contamination or underground obstructions are present.

2. Locate vacuum truck and light crane.

3. Set bottom section of casing - complete radiation survey - splice on top section of casing.

4. Use vibrator as necessary to drive casing.

5. Drive until the casing encounters the dome.

6. Measure dimension to dome - to obtain final riser dimensions finish fabricating riser.

\section{SET INNER CASING}

1. Locate drill rig, set swivel drive, drill string, water reservoir, pump and meter, measure to check drilling depth.

2. Set water flow, approximate rpm, down pressure with input from drill team.

3. Commence drilling of 75-mm (3-in. groove) - conduit radiation survey.

4. Finish drilling, clean groove and, survey casing shoe.

5. Set casing, grout, and allow for cure time.

6. Perform water leak test.

7. Add final grout between inner and outer casing. 


\section{SET 15-MN (1/2-IN.) RETENTION PIPE}

1. Install chuck drive, drill string centralizer and 25-mm (1-in.) drill bit.

2. Drill hole to depth, survey drill bit, and clean hole with vacuum.

3. Epoxy hole - set retention pipe and allow time to cure.

4. Perform pull test on retention pipe.

\section{E. CORE BARREL}

1. Install core barrel and drill string over the retention pipe, secure retention pipes to hoist cable.

2. Set drive, water meter, approximate rpm, down pressure, measure to dome.

3. Drill - until almost through dome, survey core barrel, withdraw, core barrel, clean hole. Add final quantity drilling water, finish drilling withdraw core and core barrel. Maintain tension on retention pipe to hold core plug.

4. Temporarily shield over top of outer casing.

5. Disassemble core plug from core barrel and dispose of core plug.

5. Survey core barrel.

\section{F. SET RISER}

1. Move drill rig, locate light crane.

2. Remove temporary shielding, set and plumb riser, place initial grout seal, allow for cure time.

3. Perform water leak test.

4. Add final grout between inner casing and riser.

5. Slab around riser at grade.

\section{G. DEMOBILIZE}

1. Survey drill rig, dritl bits and miscellaneous equipment.

2. Relocate or remove from the tank farm. 


\section{APPENDIX H}

\section{Selected Portions of Engineering Study}


WHC.SD-WM-ES-299, ReV. 0

\section{ENGINEERING STUDY \\ INSTALLATION OF NEW RISERS IN \\ SINGLE-SHELL TANKS \\ WORK ORDER ER5511}

\section{INTRODUCTION}

A sampling program is being developed to characterize the 149 underground SSTs on the Hanford Site. The sampling effort will require access to the tank interior in a minimum of two locations per tank. Some of the risers suitable for sampling are either unavailable or are not in locations for proper characterization of the tank contents. Additional risers will be required in the SSTs to support the tank characterization sampling program.

The purpose of this engineering study is to review alternatives for installation of new risers in the SSTs.

II. SUMMARY AND CONCLUSIONS

\section{A. TANK AND RISER CONFIGURATION}

To characterize each SST, at least two samples of the tank contents will be required. One sample will be obtained from near the tank wall and a second sample from near the center of the tank. At least one existing riser is available for sampling near the tank wall for the majority of the SSTs \{ref 11 . This engineering stuc'y presents alternatives for the installation of new risers, preferably within a 20 - $\mathrm{ft}$ radius of the tank center or in other areas of the tank as deemed necessary by sampling requirements or as obstructions from tank equipment allow.

There are 149 SSTs on the Hanford site ranging from 55,000 to 1,000.000-gal capacity (25 tanks have a 1,000,000-gal capacity. 
WHC-SD-WM-ES-299, REV. 0

36 tanks have a 758,000 -gal capacity, 72 tanks have a $530,000 \cdot \mathrm{gal}$ capacity, and 16 tanks have- 55,000-gal capacityl. Tha $1,000,000$, 758,000, and 530,000-gal capacity tanks have a 75-ft inside diameter but vary in height. The 55,000-gal SSTs have a 20-ft inside diameter. This study will focus on the 133 tanks with a 75 -ft diameter. Access for sampling of the 55,000-gal tanks will be studied and reported separately. if required.

The underground 75-ft diameter SSTs provide waste confinement by a single low carbon steel ali welded inner liner within a reinforced concrete structure or shell. Each SST has a usable waste depth of approximately 16 to $30 \mathrm{ft}$ at the sidewall. The bottom of the tank consists of a 6 -in. layer of reinforced concreta covered with a 2 -in. layer of grout and a 3/8-in. thick steel plate liner. The tank walls are 13-in. thick reinforced concrete. The steel liner extends 18 to $31 \mathrm{ft}$ up the straight side of the shell, varying in thickness from $3 / 8$ to $1 / 4$ in. A 15 -in. thick reinforced concrete dome is integral to the 13-in. thick reinforced concrete outer shell and is exposed to the tark waste. Steel liners weie rut provided for the concrete structural dome.

Summaries of the 149 SSTs located in the 200-West and 200-East Areas are shown in Tables 1 and 2 .

TABLE 1

\begin{tabular}{|c|c|c|c|}
\hline \multicolumn{3}{|c|}{ 200-W AREA SINGLE-SHELL TANKS SUMMARY } \\
\hline $\begin{array}{c}\text { Year } \\
\text { Constructed }\end{array}$ & $\begin{array}{c}\text { Tank } \\
\text { Farm }\end{array}$ & $\begin{array}{c}\text { Number } \\
\text { of Tanks }\end{array}$ & $\begin{array}{c}\text { Capacity } \\
\text { (gal) }\end{array}$ \\
\hline $1943-44$ & $\mathrm{~T}$ & 12 & 530,000 \\
\hline $1943-44$ & $\mathrm{~T}$ & 4 & 55,000 \\
\hline $1951-52$ & $\mathrm{TY}$ & 6 & 758,000 \\
\hline $1947-48$ & $\mathrm{TX}$ & 18 & 758,000 \\
\hline $1943-44$ & $\mathrm{U}$ & 12 & 530,000 \\
\hline $1943-44$ & $\mathrm{U}$ & 4 & 55,000 \\
\hline $1953-54$ & $\mathrm{~S}$ & 12 & 758,000 \\
\hline $1953-54$ & $\mathrm{SX}$ & 15 & $1,000,000$ \\
\hline
\end{tabular}


TABLE 2

\begin{tabular}{|c|c|c|c|}
\hline \multicolumn{3}{|c|}{$200-E$ AREA SINGLE-SHELL TANKS SUMMARY } \\
\hline $\begin{array}{c}\text { Year } \\
\text { Constructed }\end{array}$ & $\begin{array}{c}\text { Tank } \\
\text { Farm }\end{array}$ & $\begin{array}{c}\text { Number } \\
\text { of Tanks }\end{array}$ & $\begin{array}{c}\text { Capacity } \\
\text { (gall }\end{array}$ \\
\hline $1948-49$ & BY & 12 & 530.000 \\
\hline $1946-47$ & BX & 12 & 530.000 \\
\hline $1943-44$ & B & 12 & 530,000 \\
\hline $1943-44$ & B & 4 & 55.000 \\
\hline $1943-44$ & C & 12 & 530,000 \\
\hline 1943.44 & C & 4 & 55.000 \\
\hline $1954-55$ & A & 6 & 1.000 .000 \\
\hline 1963.64 & AX & 4 & 1.000 .000 \\
\hline
\end{tabular}

\section{B. GENERICTANKS}

- This study devalefs a neve rise: instellavisn ganeric for 133 of the SSTS. The tanks are in 12 of the tank farms and each tank dome has a different configuration of risers, pits, and piping. Two generic tank pians were created to show this variation:

- A "congested" tank plan (see Figure 1)

- A "less congested* tank plan (see figure 2)

Typical elevations of these tanks are shown in Figures 3 and 4 . The C Tank Farm is an example of a congested tank farm with Tank 241-C.104 selected as a typical "congested" tank installation. A less congested farm is the $T$ Farm with Tank 241-T-107 selected as a typical "less congested" tank installation. 
WHC-SD-WM-ES-299, Rev. O

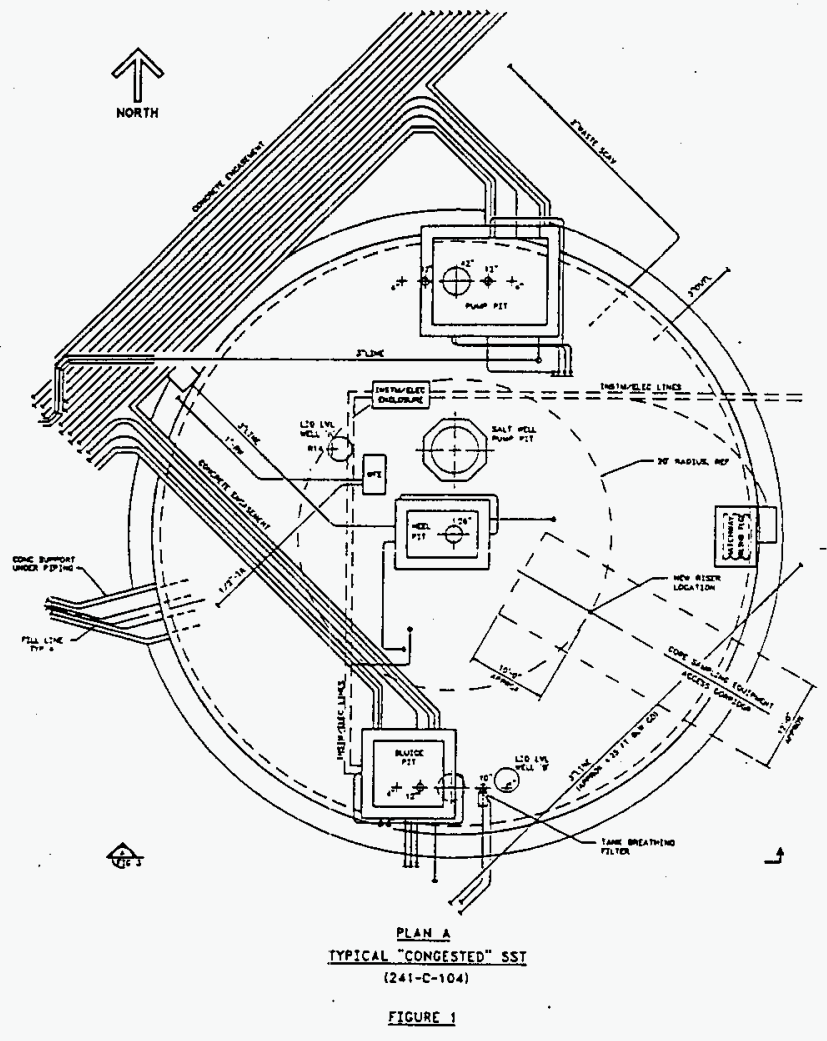

ER5511ER.TD.2906 
WHC-SD-WM-ES-299, Rev, O

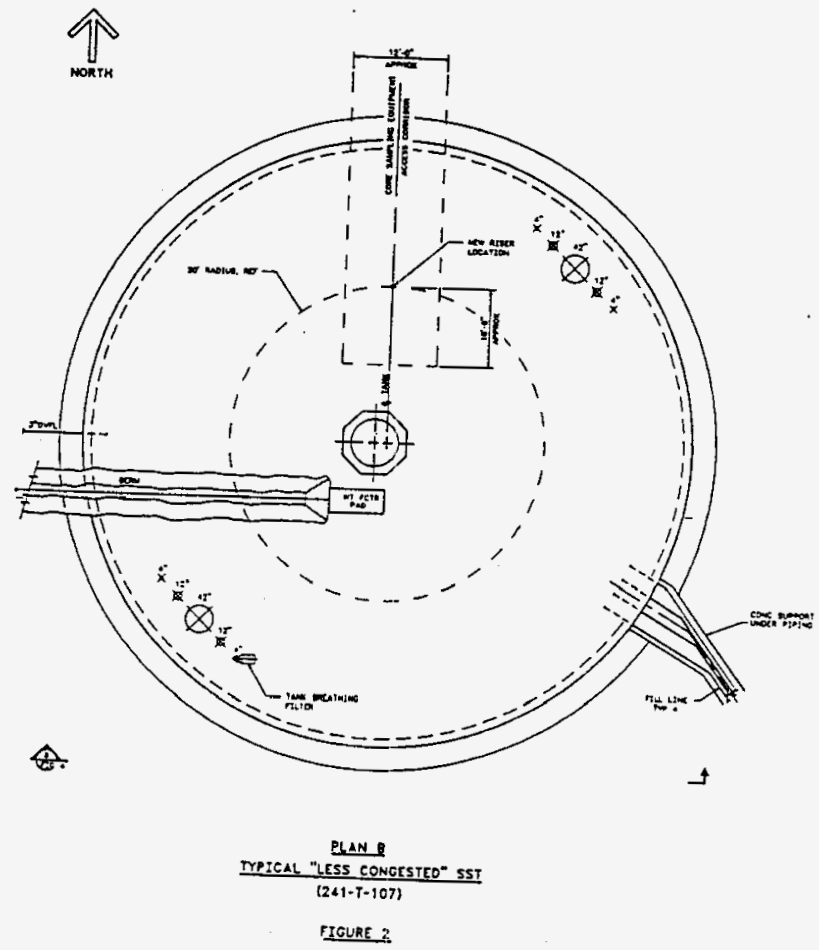


WHC-SD-WM-ES-299, ReV. O

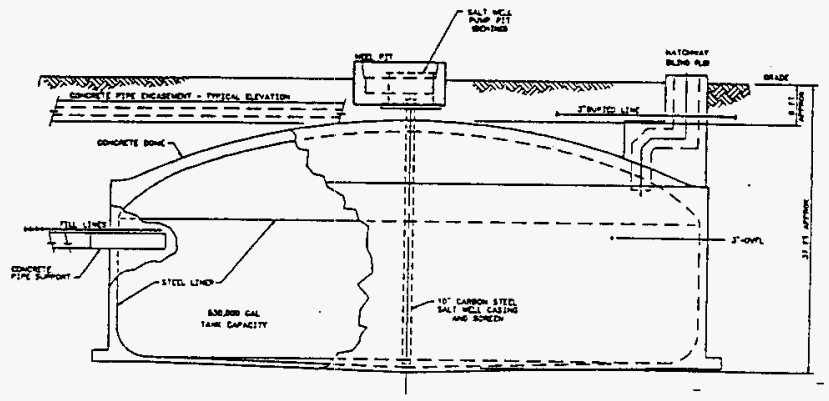

ILCVAIION

IYPICAL "CONCESTEO" S5T

$(241-c-104)$

FICURE 3 


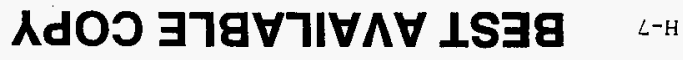

$\rightarrow 6 / 81 / 80$

उप्रत्रा?

$(<01-1-1+2)$

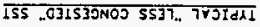

gNOIIVAJ3

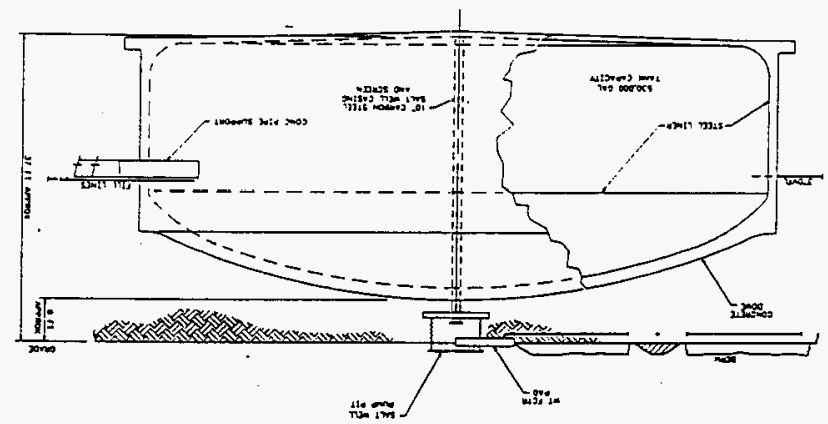

० คคํ '66Z-SJ-WM-GS-วHM 
WHC-SD-WM-ES-299, Rev, 0

A congested tank larm will limit the location of new risers due to obstructions and interierences from existing underground-piping and pits. An approximately $\$ 20,000$ allowance was made for additional work required to support or shore utilities in a congested tank farm. The SST plans show typical locations for proposed new risers and their support equipment with the existing tank tisers, utility pits, and underground concrete encasemenis and piping.

Radiation dose rates for personnel installing new risers will vary for each of the 133 SSTs. Dose rate measurements or estimates for the various SSTs have not been recorded and a generic dose or average dose rate could not be estimated. For this study, a "low," "medium," and "high" dose rate range was selected. A low dose rate was assumed to be less than $25 \mathrm{mRem} / \mathrm{hr}$. Medium dose rate was between 25 and $500 \mathrm{mRem} / \mathrm{hr}$. Greater than $500 \mathrm{mflem} / \mathrm{hr}$ was selected as a high dose rate. Different estimates were prepared for each alternative using these low, medium, and high dose rates.

C. RISER SIZE

A 12-in. new riser size was selected to allow the new riser to serve a variety of purposes. Sampling with the rotary truck will require a minimum 4-in. riser. Ventilation requirements during the sampling process requires an additional 6 - to 12 -in. riser. Other programs (e.g.. the light duty utility arm) require a 12 -in. tiser. The cost differential for installing either a 4 - or 12 -in. riser should be minimal.

\section{RISER INSTALLATION COSTS}

In the past, Construction Forces installed risers in the SST domes. Hand excavation methods were used to access the tank dome and a diamond core drill was utilized to penetrate the tank dome. A new riser pipe was fabricated and installed in the dome penetration. The excavation was backfilled and a concrete surface pad was poured around the riser at 
WHC-SD-WM-ES-299, Rev. 0

ground level, as necessary. This was considered a basic construction activity and environmental restraints were not so restrictive at that time. The cost of installing a riset, estimated to be less than $\$ 5,000$. included material and tabor costs and did not include WHC overhead costs.

Table 3 shows the costs for the various alternatives assuming all costs would be applied to installation of a single riser in one tank. The costs shown in the table include HVAC, core drilling, and supporting equipment required to install one new 12 -in. riser. Cost estimates were prepared for low, medium, and high radiation zones in a noncongested tank farm (see Appendix Al. An additional estimate was developed for hand excavating in a congested tank farm.

TAELE 3

\begin{tabular}{|c|c|c|c|c|}
\hline \multicolumn{5}{|c|}{ ESTIMATED COST OF RISER IHSTALLATION } \\
\hline & \multicolumn{3}{|c|}{ Kanconges ted tank Ierm } & Conges ted \\
\hline$\therefore \quad$ Alternative & \multicolumn{3}{|c|}{ tadistion ares } & $\begin{array}{l}\text { adiation } \\
\text { Ares }\end{array}$ \\
\hline$\because \quad \because \quad \square$ & (i) & $\begin{array}{l}\text { Medium } \\
\text { (\$) }\end{array}$ & High & (ow \\
\hline $\begin{array}{l}\text { Alternutive 1: Mand Excevtete } \\
\text { Soll Cover and safely slopt } \\
\text { Overburden. }\end{array}$ & $2,383,000$ & $3,669,000$ & $10,334,000$ & $2,403,000$ \\
\hline $\begin{array}{l}\text { Alternutive 2: Mand Excovate } \\
\text { uith shering. }\end{array}$ & $1,361,000$ & (i) & (1) & (ग) \\
\hline $\begin{array}{l}\text { Alteresative 2a: Hand Excavale } \\
\text { with Coisgon }\end{array}$ & 931,000 & $1,698,000$ & $4,019,000$ & (1) \\
\hline $\begin{array}{l}\text { Altermative 3: Install kisers } \\
\text { with Rotory orilling fouipment }\end{array}$ & 738,000 & $1,207,600$ & $3,715,000$ & (1) \\
\hline $\begin{array}{l}\text { Alternative t: Abrasive Uater } \\
\text { det fulting for Bome Benetration }\end{array}$ & 971,000 & $1,289,000$ & $3,007,000$ & (i) \\
\hline Alternative 5: stroddte crane & $2,076,000$ & $2,455,000$ & $4,487,000$ & (1) \\
\hline
\end{tabular}

Estimates were not developed for all cases. Alternative 2 had considerable cost savings when a caisson was used instead of shoring. The second case was for the noncongested versus congested tank farm. When large equipment, such as the rotary drilling rig or straddle crane are used, the congested tank farm will limit the location where this equipment can be placed. No cost increase could be identified in a congested tank farm for this type of equipment. 
Table 4 shows the one-time set-up cost for each alternative. If a project was developed to install 5, 10, or more risers, this set-up cost could be divided among the risers reducing the cost per riser.

TABLE 4

\begin{tabular}{|l|c|}
\hline \multicolumn{2}{|c|}{ ONE-TIME SET-UP COST } \\
\hline $\begin{array}{l}\text { Alternative 1: Hand Excavate Soil Cover } \\
\text { and Safely Slope Overburden }\end{array}$ & $\$ 468,200$ \\
\hline $\begin{array}{l}\text { Alternative 2: Hand Excavation with } \\
\text { Shoring or Caisson }\end{array}$ & $\$ 468,200$ \\
\hline $\begin{array}{l}\text { Alternative 3: Install Risers with Rotary } \\
\text { Orilling Equipment }\end{array}$ & $\$ 468,200$ \\
\hline $\begin{array}{l}\text { Alternative 4: Abrasive Water Jet Cutting } \\
\text { for Dome Penetration }\end{array}$ & $\$ 971.000$ \\
\hline Alternative 5: Straddle Crane & $\$ 1.830 .000$ \\
\hline
\end{tabular}

Figure 5 shows how the cost per riser is reduced if multiple risers are installed. For a noncongested tank farm with a low radiation dose rate, the cost per riser would be as shown in Table $4 \mathrm{~A}$ if five risers are installed in a low radiation area.

\section{TABLE 4A}

\begin{tabular}{|l|c|}
\hline \multicolumn{2}{|c|}{ COST PER RISER (Minimum Five Risers) } \\
\hline $\begin{array}{l}\text { Alternative 1: Hand Excavate Soil Cover and } \\
\text { Safely Slope Overburden }\end{array}$ & $\$ 2,008,000$ \\
\hline Alternative 2: Hand Excavate with Shoring & $\$ 966,000$ \\
\hline Alternative 2a: Hand Excavate witר Caisson & $\$ 556,000$ \\
\hline $\begin{array}{l}\text { Alternative 3: Install Risers with Rotary Drilling } \\
\text { Equipment }\end{array}$ & $\$ 363,000$ \\
\hline $\begin{array}{l}\text { Alternative 4: Abrasive Water Jet Cutting for } \\
\text { Dome Penetration }\end{array}$ & $\$ 384,000$ \\
\hline Alternative 5: Straddle Crane & $\$ 610,000$ \\
\hline
\end{tabular}


COST OF MULTIPLE RISERS
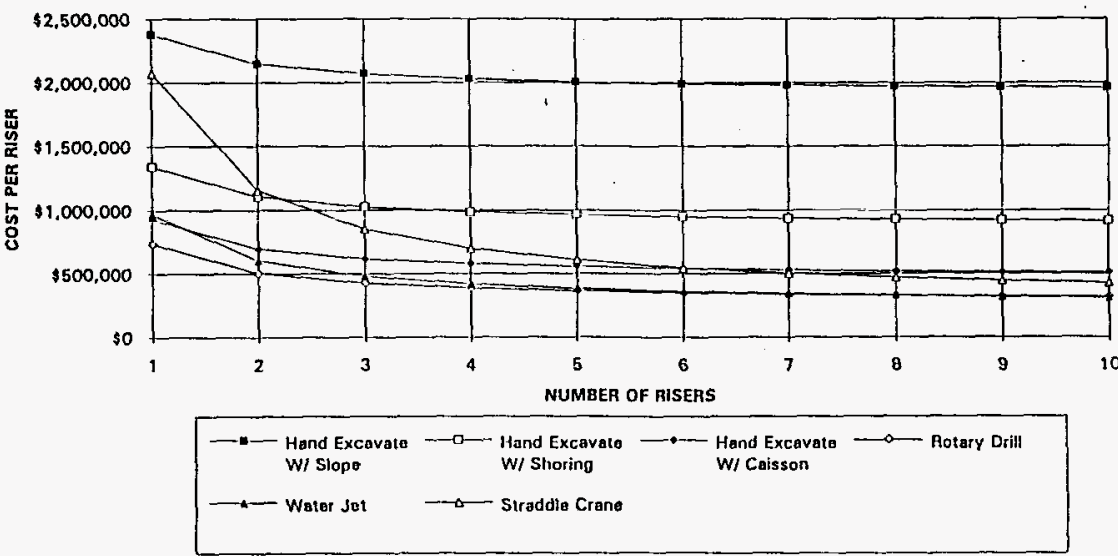

FIGUAE 5 
WHC-SD-WM-ES-299, Rev. O

\section{E. PERMITTING cosTS}

The previous section, Riser installation Costs, estimated the construction costs to add a new riser to a SST. Costs for preparing environmental permits. safety analysis, operating procedures, and other necessary documentation were not included. This section summarizes estimated costs for preparing these documents.

When an SST has been identified as requiring a new riser, environmental permits, safety evaluation. NEPA documentation, and installation procedures must be prepared. These permitting costs should be a onetime cost for a riser installation. If multiple risers are installed, permits and procedures put in place should be applicable. Table 5 summarizes the approximate costs and schedule for major permitting requirements.

TABLE 5

\begin{tabular}{|c|c|c|}
\hline \multicolumn{3}{|c|}{ PERMITTING COSTS } \\
\hline Task & Cost & Schedule \\
\hline $\begin{array}{l}\text { NEPA Documentation } \\
\text { EIS }^{1} \\
\text { EA }^{2}\end{array}$ & $\begin{array}{l}\$ 15,000 \text { to } \$ 30,000 \\
\$ 5,000 \text { to } \$ 120,000\end{array}$ & $\begin{array}{l}24 \text { months } \\
8 \text { to } 12 \text { months }\end{array}$ \\
\hline Air Fermits & $\$ 220,000$ & 8 months \\
\hline Safety Requirements & $\$ 45,000$ & 4 months \\
\hline Safeguards and Security & None ${ }^{3}$ & None $^{3}$ \\
\hline Procedure Preparation & $\$ 40,000$ & 4 months \\
\hline Total & $\$ 425,000^{4}$ & \\
\hline \multicolumn{3}{|c|}{$\begin{array}{l}\text { One option would be to include the new riser installation task in the TWRS } \\
\text { EIS. Approximate schedule } 24 \text { months. Cost shown is the portion that this } \\
\text { project would pay to be included in the TWRS EIS. }\end{array}$} \\
\hline \multicolumn{3}{|c|}{$\begin{array}{l}2 \text { Preliminary investigation has determined that an EA should be sufficient if } \\
\text { NEPA documentation is performed separately for this project. EIS would not } \\
\text { be required. }\end{array}$} \\
\hline \multicolumn{3}{|c|}{$\begin{array}{l}\text { No additional cost or schedule required if Alternatives } 2 \text { through } 5 \text { are } \\
\text { selected. Additional cost and schedule will be required if Alternative 1, Open } \\
\text { Excavation, is selected. }\end{array}$} \\
\hline \multicolumn{3}{|c|}{$\begin{array}{l}\text { Total cost includes maximum cost for EA and no cost for EIS. Subtract EA } \\
\text { cost and add } \$ 30.000 \text { to total cost if EIS is required. }\end{array}$} \\
\hline
\end{tabular}




\section{F. CONCLUSIONS}

Alternative 1, hand excavation with the overburden safely sloped has the highest cost. Little cost savings would be obtained if multiple risers were installed. Disposing of large quantities of potentially contaminated soil was the major cost.

Alternative 2 studied hand excavating with either shoring or a caisson. Reducing the amount of excavated soil reduced the total cost. Hand excavating with shoring was the third costliest alternative assuming a single riser was installed and the second costliest if multiple risers wera installed. Using caisson to shore the excavation would reduce the cost considerably when compared to Alternative 1 or 2 with shoring. Alternative 2 with a caission was the fifth costliest alternative for a single riser installation and the fourth costliest if multiple risers were installed.

Alternative 3, using available rotary drilling equipment, was the third alternative reviewed. This alternative had the lowest estimated cost for both a single riser installation and multiple riser installations.

Alternative 4 studied using an abrasive water jet installed down a small diameter riser. Costs for this approach was the fourth costliest for a single riser and the fifth costliest for multiple risers.

Alternative 5 studied using specialized equipment to install the risers. This special equipment uses a straddle crane with accessories designed for excavation, penetration of the dome, and riser installation. The cost was the highest if the equipment and procurement were charged against the cost of a single riser. Considerable cost saving resulted if the costs were divided among five risers. The straddle crane was the fifth costliest alternative, or slightly above the cost of rotary drilling if five or more risers were installed. 
WHC-SD-WM-ES-299, Rev. 0

Criteria used to evaluate the alternatives used high values for safety and ALARA principles. Straddle crane had the highest rating using these principles and should be evaluated further. Rotary drilling ranked second highest using the evaluation criteria and lowest in cost. ICF $\mathrm{KH}$ recommends that rotary drilling be tested to determine if a riser can be safely installed using available monitoring well installation and soil sampling equipment and techniques.

\section{DESCRIPTION OF ALTERNATIVES}

A. CRITERIA

The purpose of this study is to develop and report methods and estimated costs for adding tank access risers in SSTs. A new riser installation will require a method of penetrating 7 to $10 \mathrm{ft}$ of soil overburden over the tank dome, cutting a new hole in the tank dome, and installing a new riser.

\section{B. SITE PREPARATION AND CONSTRUCTION SEQUENCE}

When an SST has been identified as requiring a new riser, numerous tasks must be scheduled and completed prior to installation. These tasks include site familiarization, riser location determination, and permitting. Following is a list of tasks that have been identified by this study.

- Prepare NEPA documentation.

- Prepare safety documentation.

- Define tank and desired riser location.

- Perform research using available documentation to locate all risers, pits, underground piping, and other obstructions. 


\section{APPENDIX I}

\section{Rotary Drilling Test Plan Notations}




\section{ROTARY DRILLING TEST PLAN}

Testing for the simulated riser instatlation consists of two parts. The first part is demonstration of diamond core drilling utilizing existing reinforced concrete hatch f coverblocks. The second part is a riser installation demonstration through a column of soil into the base of an existing pipe tunnel.

Each demonstration/test will be documented by recording the preparation, testing. measurements, and photography (still and video). Test activity data sheets are included for recording the measurements and test data.

If the planned tests appear unsuccessful, drilling tools and equipment may be modified so that the demonstrations are successful. Modifications or deviations from this test plan will be noted in the master copy of the test plan. Any change to the master copy of the test plan or the rotary drilling illustrations will be approved by the ICF KH project manager and the WHC project engineer or respective designees.

F-1

\section{DIAMOND CORE BARREL DEMONSTRATION}

The purpose of the diamond core barrel demonstration is to test the various steps required to penetrate a simuloted tank dome. Several existing $229-\mathrm{mm}$ ( 9 -in.) thick concrete hatch covers will serve as test pieces for the diamond core barrel

I demonstration. Figure $F-l$ shows the configuration of the demonstration test site.

Rotary drilling illustrations are shown in Appendix $G$.

Four hateh covers will be tested and $k$ ept for further study and evaluation. Testing of each hatch cover will demonsirate separate suecessive steps of riser installation.

\section{F-1.1 Demonstration No. 1}

Demonstration No. 1 will demonstrate the use of a casing equipped with cutting teeth to drill in: o a hatch cover and demonstrate the method of forming a grout seal between the -

! casing and hatch cover (see figutes F-2A, 2B and drawing ES-E47561-C1).

- With curting teeth welded on a $457-\mathrm{mm}(18-i n$.) diameter casing. drill a minimum of $50-\mathrm{mm}(2-\mathrm{in}$.$) into the coverblock.$

- Set a plain casing into the groove cut into the coverblock.

- Place a minimum of $100 \mathrm{~mm}(4-i r$.$) of grout in the casing.$

- Rotate and raise casing slightly to allow grout to flow into the groove and spread to outside of casing.

- Reset casing and allow grout to cure per manufacturer's instructions. 


\section{F-1.1.1 Testing Preparation}

- Fabricate 457-mm (18-in.) diameter casing by cutting to length a thest grinding end sutbecs to provido-suteceserpend of to the-osing

- Select and procure diamond tipped curting teeth with proper size and configuration i for drilling teinforced concrete and rebar.

- Weld cutting teeth to casing.

GTomm

- Cut to length a $457-\mathrm{mm}(18-i n$.) diameter plain casing.

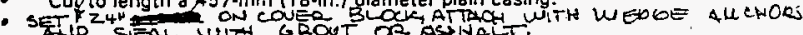

- Select and procura grout to be used for sealing casing so hatch cover.

- Develop techniques for placing grout by hand.

\section{F-1.1.1.1 Testing Preparation Documentation}

- Size, material type and dimensions of casing used. -

- Cutting teeth type, manufacturer and part number..

- Measure and document the length, OD and ID of cutting teeth attached to casing. Make measurements to an accuracy of $0.025 \mathrm{~mm}(0.001$-in.). -

1 Document the grout selected including the manuiacturer, grout type, and strength. Obtain manufactuter's recommendations and grout specifications. Obtain Material Safety Data Sheet (MSOS) for grout.

\section{F.1.1.2 Equipment Setup}

The following steps will be performed in preparztion for testing.

- Select hatch coverblock for testing.

- Move drilling rig to test site and setup according to drilling procedures.

F-1.1.2.1 Components and Materials for Testing

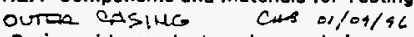

- Casing with attached cutting teeth" Msob l/q/96

- Plain casing

- Cocling water supply

- Grout

i. Testing and measuring equipment used, including calibration information 


\section{F-1.1.3 Testing Sequence}

- Document number and location of personnel required for each task. -

- Start drilling rig and engage transmission to turn drill string at the rom or gear. setring selected. Record rpm or geap setring.

- Lower drill string until casing cutting teeth touch concreze hatch cover. Fecord

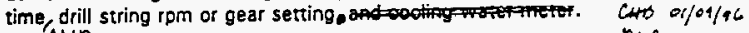

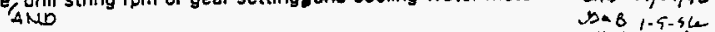

- Turn on cooling water and commence drilling. Continue drilling until the casing has reached a minimum of $50 \mathrm{~mm}(2$-in.) depth. Record drill string hydraulic pressure.

- Turn off cooling water 3 , record time and cooling water USED.

- Retract drill string and remove casing with cutting teeth.

- Mix grout per manufacturer's requirements.

- Place grout to fill casing to a minimum depth of $100 \mathrm{~mm}(4 \cdot \mathrm{in}$.) above concrete hatch coverblock. Record quantity of grout introduced into casing.

BOOM TRUCh I IS 1-4-4ke

- Using drittrg, retract and rotate plain casing until grout flows to the outside of casing. Fecoord stom usode

- Usiegnamem freset casing to the botton of the groove that was previously cut into the concrete hatch coverblock.

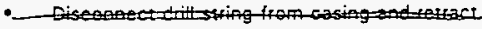

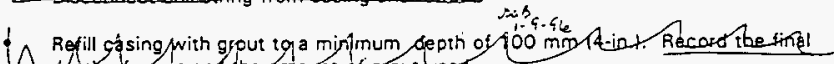
$\checkmark$ gepth of grout and ine a mount of grout weet.

- Felocate drill rig.

- Test the water leakage rate between the casing and the hatch cover using the following procedure: After the grout has cured for at least 24 hours fill interior of casing with potable water to a depth of $305 \mathrm{~mm}(12-\mathrm{in}$.$) . Record time. Allow$ grout and concrete to absorb water by waiting 30 minutes then refilling casing to depth of $305 \cdot \mathrm{mm}$ 112-in.\}. Record time water was added. Tape plastic over top end of riser to reduce evaporation. Wait 24 hours and record water depth and time. Visually inspect exterior of grout seal periodically during test to determine if any visible water leakage paths exist. 


\section{F-1.1.4 Testing Ėvaluation}

After completing each stage of testing. an evaluation will determine if changes should be made in the testing procedure. Major items to evaluate are listed below:

- Grout used. Review grout type, mixture, and placement techniques to determingit test procedure or materials require change.

- Review grout placement, depth, and amount of grout that flows out to the exterior, of the casing. Evaluate alternate methods of forcing grout to exterior of casing such as mechanical ram or hydrostatic pressure.

- Examine grout for cracks or voids after curing. Determine if grout depth needs to bo increased.

\section{F-1.9.5 Test Results}

Information from testing will bo included in a final report. Items to be documented from this test phase include the following:

- Infermation from testing preparation documentation (Section F-1.1.1.12

- Number and location of personnel required for each rask. -

- Equipment used.

- Time required to drill into hatch cọverblock.

- Amount of cooling water used for drilling.

- Information on drill string rpm or gear setting anó downward pressure.

- Time required to set plain casing.

- Grout selection, mixing documentation, and quantity used.

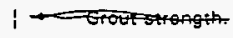

- Grout placing techniques.

i - Instrument calibration information

- Leak test results.

- Possible improvements and recommendations. 


\section{F-1.2 Demonstration Ne.2}

Demonstration No. 2 involves elements of Demonstration No. 1 plus a demonstration of core drilting through the grout seal and hatch cover (see Figure F-2C). Two hatch covers will be stacked together to demonstrate that the diamond core drill has the capability to drill through concrete as thick as (or thicker than) a SST dome.

- With cutting teeth welded on a 457-mm (18-in.) diameter casing drill a minimum of , $50 \cdot \mathrm{mm}(2-\mathrm{in}$.$) into the coverblock.$

- Set a plain casing into the groove cut into the coverblock. So $1-9-54$ $0+13$ o1/01/4L

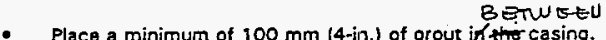
IN MED DLW OUTER

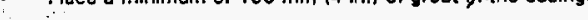

- Porare and raise casing stightly to altow grout to flow into the groove te outeride of casing.

- Reset casing and allow grout to cure per manufacturer's instructions.

- Drill a $25-\mathrm{mm}(1-\mathrm{in}$.$) diameter hoie into center of area to be cored.$

- Remove moisture from the 25-mrn (1-in.) diameter hole, insert adhesive capsule into hole, set yed into hole and rotate to break capsule and spread achesive.

- Diamond core drill through grout layer and hatch cover using core barrel assembly.

- Remove core and ccre bartel assembly from hatch cover:

\section{F-1.2.1 Testing Preparation}

- Use the $457-\mathrm{mm}$ (18-in.) diameter casing with cutting teeth as described in Secrion F-1.1.1. romm

- Gut to length a $457 \mathrm{~mm}$ (18-in.) diameter plain casing.

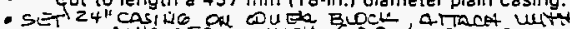

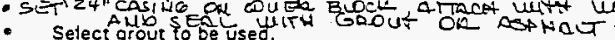

- Use grout placing fechniques selected for Demonstration No. 1, modified if necessary.

- Select and procure rod and adhesive for core retainer.

- Select and procure core barrel assembly.

F-1.2.1.1 Testing Preparation Documentation

$$
\because .
$$

- Size, material and dimensions of casing used. 
1. Document the grout used including the manufactures name, grout type, strength. and MSDS.

PIPE

- Document type of core retaining 105 and adhesive.

- Document the core barrel assembly manufacturer name and model. Measure and document the length, $O D$ and ID of the dismond cutting teeth. Make measurements to an accuracy of $0.025 \mathrm{~mm}(0.001$-in.).

\section{F-1.2.2 Equipment Setup}

The following steps will be performed in preparation for testing: wh $1-5-94$

$$
\because \text { : }
$$$$
\text { a,d } 0 . / 04 / 46
$$

i - Select and stack hatch coverbiocks for testing, SECU be WITH STRAPPIU'O:

$1 \rightarrow$. I clesinetent

- Attach pan or water collecting device to underside of coverblock to collect drilling water.

- Move drilling rig to test site and setup according to drilling procedures.

F-1.2.2.1 Components and Materials for Testing

- outele casilg .

- Casing with attached cutting teeth .

- Plain casing

- Cooling water supply.

- Grout

- Core retaining fod and adhesive

- Core barrel assembly

- Testing and measuring equipment, used, including calibration information

\section{F-1.2.3 Testing Sequence}

- Document number and location of personnel required for each task.

- Start drilling rig and engage transmission to turn drill string at the tom or gear setting selected. Record $\mathrm{pm}$ or gear setting.

- Lower drill string until casing cutting teeth touch concrete hatch cover. Record time, drill string rpm or gear setting, sas $1-9-46$

- Turn an cooling water and commence drilling. Continue drilling until the casing has ! reached a minimum of $50-\mathrm{mm}(2-\mathrm{in}$.) depth. Record drill string hydraulic pessure:

- Turn off cooling water and record time and cooling water USE. USE.

- Retract drill string and remove casing with cutting teeth. 
- Install plain casing in groove cut in cover block.

- Mix grout per manufacturer's requirements.

- Place grout till berucer mileja awo ourvia casivico hatch coverblock. Record quantity of grout introduced into casing. Boom Teuclo

- Using untill grout flows to the

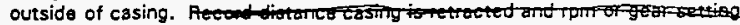
rod-

Using a-som, reset casing to the bottom of the groove that was previously cut into the concrete hatch coverblock.

- Disconnect drill string from casing and retract.

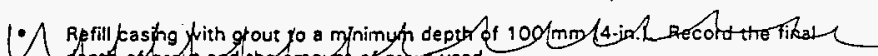
depert of grouk and the amount of groor used.

- Allow grout to cure per manufacturer's recommendations. Recoid the grout curing time.

$$
\text { ats } 0,104 / 46
$$

Drill a $25-\mathrm{mm}(1-\mathrm{in})$ diameter hole into' cente? of area to be cored $2 x$ a minimum of 100-mm (4-in.) deep into the concrete block.

- Remove moisture from the $25 \cdot \mathrm{mm}(1-$-in $)$ diameter hole, insert adhesive capsule into hole. set yodinto hole and rotate to break capsule and spread adhesive.

- Allow abhesive to cure per manuiactories recommendations.

- Tensile test rod connection with $2670 \mathrm{~N}(600 \mathrm{lbf})$ tensile force.

PIPE

- Secure to prevent core from dropping after coring.

- Attach core barrel assembly to drill string.

- Start drilling rig and engage transmission to turn drill string at the rpm or gear setting selected. Record rom or gear setting.

- Lower drill string until core barrel assembly cutting teeth touch grout. Record time, drill string rpm or gear setrirg.

$$
\text { Axb }
$$

- Turn on cooling water and commence drilling. Continue drilling until core drill is within about $25 \mathrm{~mm}$ (1 in.) of penetrating the hatch coverblock. Stop drilling and

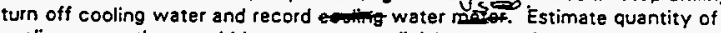
cooling water that would be necessary to finish penetrating the coverblock and fill casing and drill string with that quantity. Start and continue drilling until the hatch i coverblock is penetrated. Record drill string hydraulic pressure. 
- Retract core batrel assembly with concrete plug.

- Dissemble core bartel assembly and remove concrete plug.

- Examine and measure the diamond curting teeth. Measure to an accuracy of $0.025 \mathrm{~mm} 10.001 \mathrm{in.})$ to determine the amount of wear on the cutting teeth.

- Measure diameter and depth of hole cored through grout and concrete hatch eover. Record condition of grout seal after coring.

- Remove hatch cover and measure smount of water and cuttings contained in water collection pan.

\section{F-1.2.4 Testing Evaluation}

After completing each stage of testing, an evaluation will determine if changes should be made in the testing procedure. Major items to evaluate are listed below:

- Review grout placement depth and amount of grout that flows out to the exterior of the casing. Examine cured grout for cracks or voids. Determine if grout depth is adequate and if alternative grout placing methods are required.

1 Review method of attaching and testing core retaining lod. PIDE.

- Review drilling procedure for use of the core barrel assembly. Major items to review and evaluate are rpm or gear setting, downward pressure, and cutting rate. Evaluste amount of wear on cutring teeth to determine if assembly is suitable for reuse.

- Review the procedure used to remove the concrete plug from the core barrel assembly. Develop methods for removing concrete core from the core retaining roo under tadioactive conditions considering shielding and distance.

- Evaluate the amount of cooling water used. Develop methods to minimizing water usage.

- Evaluate diameter and length of hole cored through grout and concrete hatchcover to determine if sizes are adequate for riser installation.

\section{F-1.2.5 Test Results}

Information from testing will be included in a final report. Items to be documented from this test phase include the following:

- Information from testing preparation documentation (Section F-1.1.1.1).

- Number and location of personnel required for each task.

- Equipment used. 
I - Time required to drill into hatch coverblock.

- Amount of cooling water-used-for-driling.

- Information on drill string rpm or gear setting and downward pressure including. drill string weight and hydraulic pressure.

- Time required to set plain casing.

1 - Grout selection, mixing documentation, strength, and quantity used.

- Grout placing techniques.

- Time required to set core retaining

- Time tequired to core drill through grout and concrete hatchcover.

- Amount of cooling water that perietrates hatch cover during drilling operations.

- Core barrel assembly rpm or gear setting. hydraulic pressure, amount of cooling water used, and amount of wear.

- Diameter and depth of hole cored through grout and concrete hatchcover.

- Condition of grout seal after coring.

- Possibie improvements and recomimendations.

\section{F-1.3}

$$
\text { Demonstration No. } 3
$$

$$
\begin{aligned}
& \text { uns } 1.9-96 \\
& \text { cuss } 0.104 / 96
\end{aligned}
$$

Demonstration No. 3 includes elements of Demonstrations No. 1 and 2 -

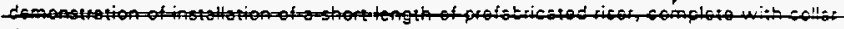

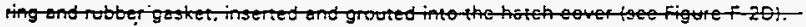

- With cutting teeth welded on a $457 \cdot \mathrm{mm}$ (18-in.) diameter casing drill a minimum of $50 \mathrm{~mm}(2-$ in.) into the coverblock.

- Set a plain casing into the groove cut into the coverblock.

- Place a minimum of $100 \mathrm{~mm}(4-i n$.$) of grout in the casing.$

- Rotate and raise casing slightly to allow grout to flow into groove and spread to outside of casing.

- Reset casing and allow grout to cure per manufacturer's instructions.

1 Drill a 25-mm (1-in.) diameter hole into center of area to be cored. 
Dry the 25-min (1-in.) diameter hole, insert adhesive capsule into hole, set re hole and rotate to break capsule and spread adhesive.

- Diamond core drill through grout layer and hatch cover using core barrel assembly.

- Remove core and cors batrel assembly trom hatch cover.

i

- A Pláce prefabricateg 305-mm 112-in. - riser inside $457-\mathrm{mm}$ 178-n.l casing and through the-cored hatch coverbletk.

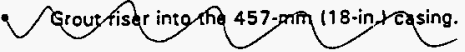

$$
\sin 1-9-96
$$

F-1.3.1 Testing Preparation

- Use the $457 \mathrm{~mm}(18-i n$.$) diameter casing with cutting teeth as described in$ Section F-1.1.1.

- $610 \mathrm{~mm}$

- Cut to Vength a $457 \mathrm{~mm}$ (18-in.) diameter plain casing.

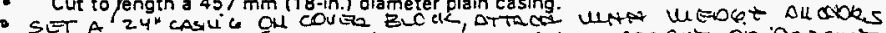

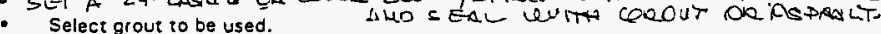

- Use grout placing techniques selected for Demonstrations No. 1 and 2.

- Use retaining PIFE

- Use retaining cor attachment techniques selected for Demonstration No. 2.

- Use core barrel assembly from Demonstration No. 2.

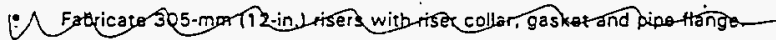

- F-1.3.1.1 Testing Preparation Documentation -

- Size, material and dimensions of casing used.

1 Document the grout used including the manufacturer name, grout type, strength, and MSDS.

1. Document type of core retaining sed and athesive.

- Document the core barrel assembly manufacturer name and modet.

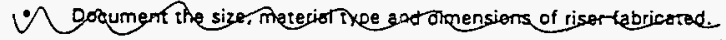

\section{F-1.3.2 Equipment Setup}

The following steps will be performed in preparation for testing:

- Select hatch coverblock for testing 
- Attach pan or water collecting devise to underside of coverblock to collect drilling water.

- Move drilling rig to test site and setup according to drilling procedures.

\section{F-1.3.2.1 Components and Materials for Testing}

- Casing with artached cutting teeth .

- Plain casing

- Cooling water supply

- Grout pipE

| Cora retaining foo and adhesive

- Core barrel assembly

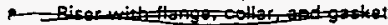

| - Testing and measuring equipment used, including calibration information.

\section{F-1.3.3 Testing Sequence}

- Document number and locations of personnel required for each task.

- Start drilling rig and engage transmission to turn drill string at the rpm or gear setring selected. Record ipm or gear setting.

- Lower drill siring until casing cutting teeth touch concrete hatch cover. Record time, drill string rpm or gear setting. and atio

- - Tum on cooling water and commence dilling. Centinue drilling until a minimum of I $50 \mathrm{~mm}(2$-in.) depth is reached. Record drill string hydraulic pressure.

- Turn off cooling water and record time and cooling water USE.

- Retract drill string and remove casing with cutting teeth.

- Install plain casing in groove in coverblock.

- Mix grout per manufacturer's requiriments.

- Using grouting techniques chosen, fill casing to a minimum depth of $100-\mathrm{mm}$ (4-in.) above concrete hatch coverblock. Record quantity of grout introduced into casing. Boom TeUch

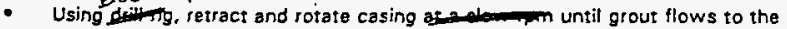
outside of casing. Fendistanco-asing 4.

Booin Thuri

- Using and reset casing to the bottom of the groove that was previously cut into the concrete hatch coverbicick.

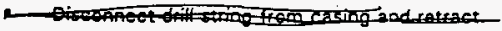




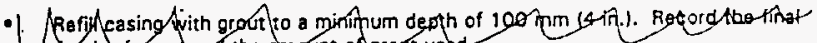
$\checkmark$ depth grout and the andunt of geodt usbot.

- Allow grout to cure per manulacturer's recommendations. Record the grout curing time.

- Drill a $25-\mathrm{mm}(1-$ in.) diameter hole into center of area to be cored at a minimum of $100 \mathrm{~mm}$ (4-in.) deep, in concrete block.

- Rerrove moisture from the $25 \cdot \mathrm{mm}(1-\mathrm{in}$.$) diameter hole, insert adhesive capsule$ into hole, set pod into hole and rotate to break capsule and spread adhesive.

- Allow adhesive to cure per manufactories recommendations.

- Tensile test rod connection with $2670 \mathrm{~N}$ (600 lbf hensile force

pip

- Secure go to prevent core from dropping after coring.

- Attach core barrel assembly to drill string.

- Start drilling rig and engage transmission to turn orill string at the rpm or gear setting selected. Record rpm or gear setting.

Lower drill string until core barref assembly cutting teeth touch grout. Record time drill string $\mathrm{rpm}$ aneocingm

$$
\text { Ando }
$$

- Turn on cooling water and commence drilling. Continue drilling until ccie drill is within about $25 \mathrm{~mm}$ ( 1 in.) of penetrating cover block. Stop drilling and turn off

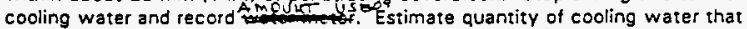
would be necessary to finish drilling through the hateh eoverblock and fill casing and drill stem with that quantity. Start and continue drilling until coverblock is

i. penetrated. Record drill string hydraulic pressure.

- Retract core barrel assembly with isoncrete plug.

- Disassemble core barrel assembly and remove concrete plug.

- Examine and measure the diamond cutting teeth. Measure to an accuracy of $0.025 \mathrm{~mm} 10.001 \mathrm{in}$.) to determine the amount of wear on the cutting teeth.

- Measure diameter and depth of hole cored through grout and concrete hatch cover. Record condition of grout seal after coring.

- Remove hatch cover and measure amount of water and cutting contained in the water collection.pan.

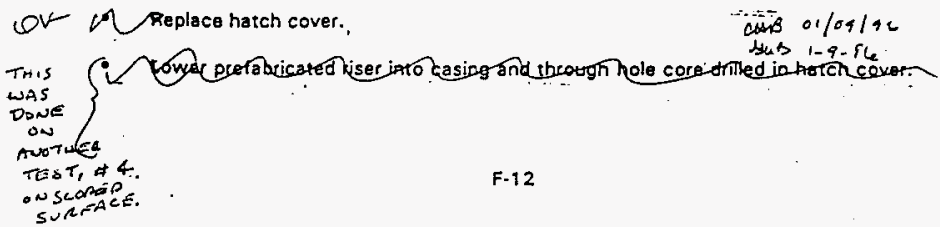


- Set riser verriosily and orout anhulus betwen casing and

- Aliew arbut to core per manufacturecorecommendations.

- Remove hatch coyer and deterning amount of groutleakage past the fiser collar and gasket into the hater eollection ean.

- CAplace hatch cover.

F-1.3.4 Testing Evaluation

After completing each stage of testing, an evaluation will determine if changes should be made in the testing procedure. Major items to evaluate are listed below: I

- Review drilling procedure for use of the core barrel assembly. Major items to review and evaluate are rpm,or geat serting selected. downward pressure, and cutting rate obtained. Evaluate amount of wear on cutting teeth to determine if assembly is suitable for reuse.

vans $1-5-96$

- LReviewfiser instaीlation seguence Evaluate merthods to reducoradiation exposure while installing oveke open riser.

\section{F-1.3.5 - Test Results}

Information from testing will be included in a final report. Items to be documented from this test phase include the following:

- Information from testing preparation documentation (Section F-1.1.1.1).

- Number and location of personnel required for each asic.

- Equipment used.

- Time required to drill into hatch coverblock.

- Amount of cooling water used for drilling.

- Information on drill string rpm or gear setting and downward pressure, including drill string weight and hydraulic pressure.

- Time required to set plain casing.

| Grout selection, mixing documentation, strenght, and quantity used.

- Grout placing techniques.

- Time required to set core tetaining seo and adhesive curing time.

- Time required to core drill through grout and concrete hatchcover. 
WHC-SD-WM-AP-O34, Rev, 1

- Amount of cooling water that penetrates hatch cover during drilling operations.

1 - Core barrel assembly rpm or gear setting, hydraulic pressure, cooling water

requirements and amount of wear.

- Diameter and depth of hole cored through grout and concrete hatchcover.

- Condition of grout seal after coring.

- Amount of grout that flows to the underside of hatch cover dyjing riser annulus grouting activity.

- Possible improvements and recommendations.

\section{F-9.4 Demonstration No. 4}

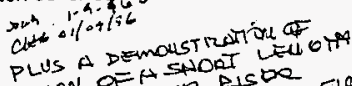

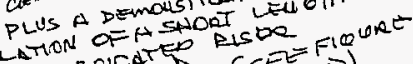

Demonstration No. 4 will include elements of Demonstrations No. 1 through 3 bur with added features as shown in Sketch ES.E47561-C1. ANS.

- Install 3 layers of building paper, wire fabric and grout on a hatch coverblock. Allow grout to cure a minimum of 3 days before attempting to temove. yas $\$ 5-56$

- Install a $610-\mathrm{mm}$ (24-in.) diameter riser on the sloped hatch cover. A that to co v sie

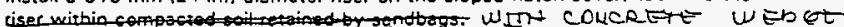

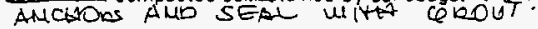

Design and fabricate a cutting tool to remove building paper and reinforced grout from the surface of the hatch cover.

- Mount cutting 1001 on drill rig and remove grout and building paper from the surface of the hatch cover.

- With cutting teeth welded on a $457 \cdot \mathrm{mm}$ (18-in.) diameter casing, set the casing by drilling minimum of $50 \mathrm{-mm}(2 \cdot \mathrm{in}$.$) , on the high side into the coverblock.$

- Place a minimum of $100-\mathrm{mm}(4-\mathrm{in})$ of grout in the casing.

- Rotate and raise easing slightly to allow grout to flow into the groove and spread outside of casing. grout should flow in space between inner and outer casing.

- Reset inner casing and allow grout to cure per manufacturer's instructions.

- Remove moisture from the $25-\mathrm{mm}(1-$ in.) diameter hole, insert adhesive capsule into hole, set ud into hole and rotate to break capsule and spread adhesive.

$$
\text { PIPE }
$$

- Diamond core drill through grout layer and hatch cover using core barrel assembly.

- Remove core barrel assembly from hatch cover. 
- Place prefabricated $305-\mathrm{mm}(12-\mathrm{in})$ riser inside the $457-\mathrm{mm}(18-i n$.) casing and through the cored hatch coverblcck.

- Grout riser to the $457-\mathrm{mm}(18-\mathrm{in}$.$) casing.$

\section{F-1.4.1 Testing Preparation}

- Set hatch coverblocks on slope.

- Install building paper and reinforced grout on hatch coverblock.

- Fabricate 510-mm (24-in.) outer casing and casing supports. Install outer casing on hatch cover.

- Design and fabricate cutting tool.

- If cutting teeth on the $457 \cdot \mathrm{mm}(18 \cdot \mathrm{in}$.$) casing used in Demonstrations No. 1$ through 3 are not worn excessively, use for Demonstration No. 4 .

- Select grout to be used.

- Use grout placing techniques selected for Demonstrations No. 1 through 3. -

PleE

- Use retaining fortachment techniques from Demonstrations No. 2 and 3.

- Use core bartel assembly from Demonstrations No. 2 and 3.

- Fabricate 305-mm (12-in.) risers with ris gasket

F-1.4.1.1 Testing Preparation Documentation

- Document fabrication techniques for both inner and outer casings.

- Document type of building paper and wire fabric used.

1 - Document the grout used including the manufacturer name, grout type, strength. and MSDS.

i PIPE

- Document type of core retaining-ed and adhesive.

- Document the core barrel assembly manufacturer name and model.

- Document the size, material type, manufacturer and dimensions of riser fabricated.

\section{F-1.4.2 Equipment Setup}

The following steps will be performed in preparation for testing:

- Select hatch coverblock for testing, slope coverblocks. 
- Artach pan or water collecting device to underside of coverblock to collect drilling water.

- Move drilling rig to test site and setup according to drilling procedures.

\section{F-1.4.2.1 Components and Materials for Testing}

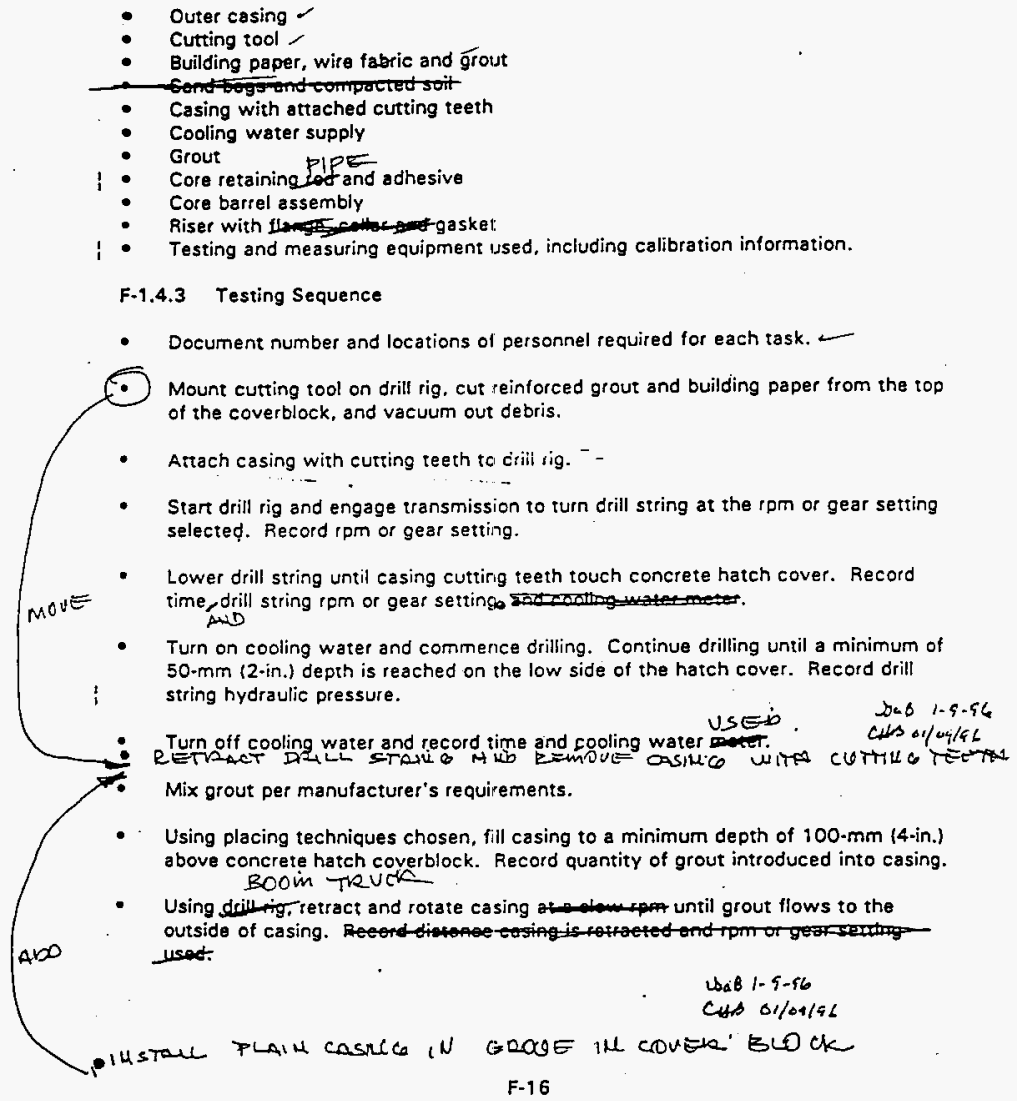


- Using a slow ipm, reset casing to the bottom of the groove that was previously cut into the concrete hatch coverblock.

- RêractArill stuing.

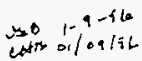

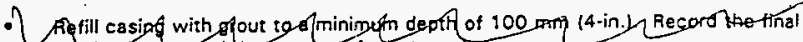
depthor grautand tho amoum of grout used.

- Allow grout to cure per manufacturer's recommendations. Record the grout curing time.

- Drill a $25-\mathrm{mm}$ ( 1 -in.) diameter hole into center of area to be cored at a minimum of $100 \mathrm{~mm}$ (4 in.) deep into the concrete block.

- Remove moisture from the $25 \cdot \mathrm{mm}(1$-in.) diameter hole, insert adhesive capsule into hole, set ped iste hole and rotate to break capsule and spread adhesive.

- Allow adhesive to cure per manufactories recommendations.

- Tensile test tod connection with $2670 \mathrm{~N}\{600 \mathrm{~b}$ i $)$ tensile force.

- Secure Forto prevent core from isropping after coring.

- Attach core batrel assembly to orill string.

- Start drilling rig and engage transmission to turn drill string at the rpm or gear. setting selected. Record rpm.or gear setting.

- Lower drill string until core barrel assembly cutting teeth touch grout. Record time frill string $\mathrm{rpm}_{\infty}$

- Turn on cooling water and commence drilling. Continue drilling until core drill is within about $25 \mathrm{~mm}$ ( $\mathrm{i}$ in.l of peretrating coverblock. Stop dilling and turn off cooling wates and record cooling water Us Gutimate quantity of cooling water that would be necessary to finish penetrating hatch coverblock and fill casing and drill string with that quantity. Start and continue drilling until hatch coverblock is penetrated. Record drill string hydraulic pressure.

- Retract core barrel assembly with concrete plug.

- Dissemble core barrel assembly and remove concrete plug.

- Examine and measure the diamond cutting teeth. Measure to an accuracy of $0.025 \mathrm{~mm}(0.001 \mathrm{in.})$ to determine the amount of wear on the cutting teeth.

- Measure diameter and depth of hole cored through grout and concrete hatch cover. Record condition of grout seal after coring. 
- Remove hatch cover and measure amount of water and cutting contained in the water collection pan.

- Replace hatch cover.

- Set riser vertically and grout annulus between casing and riser.

- Allow grout to cure per manufacturer's recommendations.

- Remove hatch cover and determine amount of grout leakabe past the riser collar and gasker.

- Replace hatch cover.

\section{F-1.4.4 Testing Evaluation}

After completing each stage of testing, an evaluation will determine if changes should be made in the testing procedure. Major items to evaluate are listed below:

- Evaluate use of cutting tool to remove grout and building paper.

Raview drilling procedure for use of the core barrel assembly. Major items to review and evaluate are rpm,or gear setting selected, downward pressure, and cutting rate. Evaluate amount of wear on cutting teeth to determine if assembly is suitabie for reuse.

- Review riser installation sequence. Evaluste methods to reduce radiation exposure while installing over an open riser.

\section{F-1.4.5 Test Results}

information from testing will be includecl in a final report. Items to be documented from this test phase include the following:

- Information from testing preparation documentation (Section F-1.1.1.1).

- Number and location of personnel required for each task.

- Equipment used.

- Time required to remove reinforced grout and building paper.

- Time required to drill into hatch coverblock.

- Amount of cooling water used for drilling. 
- Information on drill string rpm or gear setting and downwaro pressure during serting of casing.

- Time required to set inner casing.

1 - Grout selection, mixing documentation, strength, and quantity used.

- Grout placing techniques.

1 - Time required to set coireretaining peos and adhesive curing time.

- Time required to core drill through grout and concrete hatchcover.

- Amount of cooling water that penetrates hatch cover during drilling operations.

- Core barrel assembly rom or gear setting, hydraulic pressure, cooling water

requirements and amount of wear.

- Condition of grout seal after coring.

- Diameter and depth of hole cored through grout and concrete hatch cover.

- Amount of grout that flows to the underside of hatch cover during riser annulus

- grouting activity.

- Fossible improvements and recommendations.

F-2 SIMULATED RISER INSTALLATION DEMONSTRATION

The first portion of this test plan perforrned four demonstrations on concrete hatch covers. These demonstrations developed techniques for setring an inner casing. grout sealing between casing and simulated dome, diamond core drilling through simulated dome, installation of riser, and removal of building paper and reinforced grout. Results from these demonstrations will be incorporated in a simulated full scale riser installation demonstration. Additionally, this demonstration will include outer casing installation

i using an air conveyance sysiem.

\section{F.2.1 Demonstration No. 5}

A simulated riser installation demonstration will be performed at the test site by filling a vertical-1200-mm (48-in.) diameter corrugated metal pipe braced inside the pipe tunnel with compacted soil and installing a riser inside the corrugated metal pipe. The riser installation demonstration will consist of seven major parts:

- Setting an outer casing using an air conveyance system for soil removal.

- Setting an inner casing using a rotary drill rig.

- Grouting of casing to simulated tank dome (bottom of pipe tunnel).

F-19 
- Setting core retaining yot.
- Diamond core drilling through simulated tank dome using a core barrel bit.

- Installing a prefabricated riser.

i

- Grouting between riser and inner casing.

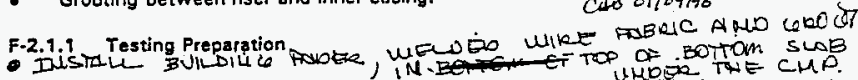

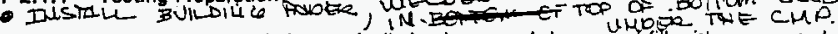

- Install corrugated metal pipe vertically in pipe tunnel, brace and fill with compacted soil.

- Fabricate a 5:0-mm (24-in.) outer casing.

- Fabricate 457-mm (18-in.\} diameter casing with cutting teeth as described in Section F-1.1.1.

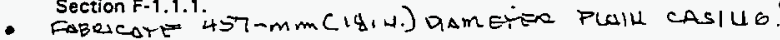

- Select grout based on recommendations from Demonstrations No. 1 through 4.

- Use grout placing techniques selected from Demonstrations No. 1 through 4.

i 7 Pि

- Use retaining jor attachment techniques from Demonstrations No. 2 through 4.

- Use core barrel assembly used in Demonstrations No. 2 through 4.

- Fabricate 305-mm (12-in.) riser with gaskei.

- Set and grout riser.

\section{F-2.1.2 Testing Preparation Documentation}

- Document the casings components and fabrication techniques as outlined in Section F-1.1.1.

Document the grout selected including the manufacturer's name, grout type. strength, and MSDS.

$$
P(P E
$$

- Document type of core retaining sot and adhesive.

- Document the core barrel assembly manufacturer name and model. Obtain ine cafufactuter's recommendetions for-pm-coling-requirements.

- Document the size, material type, manufacturer, and dimensions of riser fabricated. 
WHC-SD-WM-AP-034, Rev. 1

\section{F-2.i.2 Equipment Setup}

The iollowing steps wiil be perfornted in preparation for testing.

- Position drill rig at corrugated matal pipe location. CUS $0110115 \mathrm{C}$

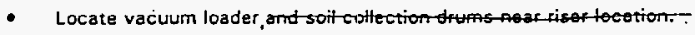

- - tocatedrum handing equipmemt near-site:-

F-2.1.2.1 Components and Materials for Testing

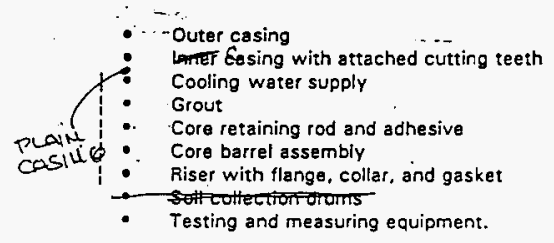

F-2.1.3 Testing Sequence

- Document number and locations of personnel required for each task.

- Start vacuum loader and begin excavation of starter hole approximately $610 \mathrm{~mm}$

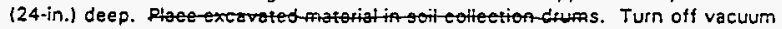
loader.

- Lowertouter casing into starter hole.

BoOm TRUCK-

- Attach casing torig for handling during serting.

- Place vacuum hose through outer casing to the bottom of the excavation.

- Start vacuum loader and continue soil temoval from the bottom of the excavation.

- Advanca cans at/04/+6 jas $1-9-54$

- Advance casing as vacuum loader removes soil. SPLICE TOP SECTOUL OF CASIUG AS REQ UlkE:

- Continue excavating soil and advancing casing until bottom concrete siab of tunnel is encountered. Shut off vacuum loader when all soil is removed from interior of casing and remove vacuum hose.

biob $1-5-96$

- Attach joner casing to drill string. Start drill rig and engage transmission to turn drill string at rpm or gear setting selected. Record $\mathrm{cpm}$ or gear setting.

- Lower drill string until casing cutting teeth touch concrete slab. Record time drill $_{\text {d }}$ string rom or gear setting, and cometer. 
- Turn on cooling water and commence drilling. Continue drilling until a minimum of $50 \mathrm{~mm}$ (1-in.) depth is reached. Record drill string hydraulic pressure.

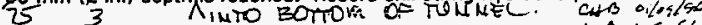
- Turn off cooling water and record time and cooling water-methas $1-4-56$

- Place and start up vacuum hose and remove all concrete cuttings, andirt. Bul L 40

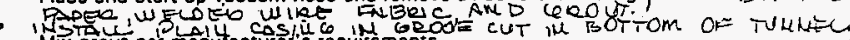

- Mix grout per manufacruter's requirements.

$$
\text { - }
$$

BETUEEN WNEQ AWO OUTEDO

- Using grout techniques chosen, fill casing to a minimum depth of $100 \mathrm{~mm}$ (4-in.) above concrese slab: Record quantity of grout introduced into casing.

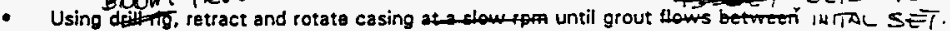

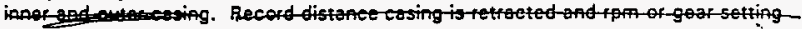
used -

- Using a slourpm, reser casing torthe bottom or the grdoverthat was previously cutinto the concrete slab.

- OAconpoct drilistring from casing-and retract.

Prefill casing with grout to a fininirnum degth of 100 mm(4-in.). Bocord the finat depth de grest and the omount of grour used (4-in.).

- Allow grout to cure per menufacturer's recommendations. Record the grout curing

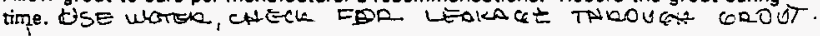

- Drill a 25-mm (1-in.) diameter hole into center of area to be cored.

- Dry the $25 \mathrm{~mm}(1$-in.) diameter hole, insert adhesive capsule into hole, set 206 into hole and rotate to break capsule and spread adhesive.

.

- Allow adhesive to cure per manufactories recommendations.

- Tensile test rod connection with $2670 \mathrm{~N}(600 \mathrm{lbfh}$ Mimilensile force.

- Secure rot to prevent core from clropping after coring.

- Attach core barrel assembly to drill string.

- Start drilling rig and engage transmission to turn drill string at the rpm selected. Record rpm.

Lower drill string until core barrel assembly cutting teeth touch grout. Record time, drill string rpm or gear setting and drill string hydraulic pressure. 
- Turn on cooling water and commence drilling. Continue drilling until core drill is within about $25 \mathrm{~mm}$ ( 1 in.) of penetrating concrete slab. Stop drilling and turn off cooling water and record cooling water estimate quantity of cooling water necessary to finish drilling and fill casing and drill stem with that quantity. Finish drilling through slab. Record drill string hydraulic pressure.

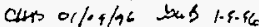
NOTE METNOOS TO SED AKATE-PLVG

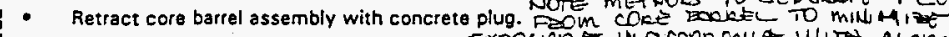

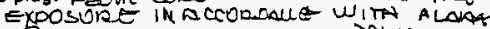

- Place core barred asserfbly yoth coficrete plug into simulated hazardous waste drugn add caphlaste dom using ALAAA work prifctples tothninize stmulated

- Examine interior of casing and penetration of concrete slab with downhole camera.

- Lower prefabricated riser into casing and through hole core drilled in concrete slab.

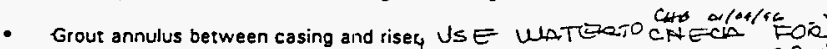
vaka ge THRoucat corout.

1 A Grgut to fillannulys between incer and outer cosing.

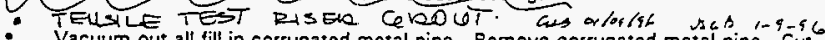
Vacuum out alt fill in corrugated metal pipe. Remove corrugated metal pipe. Cut away portions of inner casing to determine condition of riser and grout.

\section{F-2.1.4 Testing Evaluation}

After completing each stage of testing, an evaluation will determine if changes should be made in the testing procecure. Major items to evaiuate are listed below:

- Soil excavation techniques using vacuum loader system

- Methods for handling excavated soil that may be contaminated

- Outer casing installation procedure using a vacuum loader

i Methods of packaging and disposal of concrete core.

- Prefabricated riser installation procedure

I - Grouting between inner and outer casing.

\section{F-2.1.5 Test Results}

Information from testing will be included in a final report. Items to be documented from this test phase include the following:

- Information from testing preparation documentation (Section F-1.1.1.1).

- Number and location of personnel required for each task. 
- Equipment used.

- Time required to remove soil and place outer casing.

- Time required to set inner casing into concrete slab.

- Amount of cooling water used for setting of inner casing.

- Information on drill string $t$ pm or gear setting and downward pressure during setting of inner casing.

| - Grout selection, mixing documentation, strength, and quantity used.

- Grout placing techniques.

- Time required to set core retaining

- Time required to core drill through grout and concrete slab.

- Core barrel assembly rpm or gear setting cutting pressure, and amount of cooling water.

PRODOSED

- CMethod yerd to package simulated contaminated concrete core.

- Document riser dimensions used.

- Possible improvements and recommendations.

After completing the demonstrations and simulation, the drill rig and associated equipment will be removed from the test site. The following steps will be required:

- Demobilize drill rig

- Remove all equipment and obbris from test site

- Batricade or cover all openings in pipe tunnel.

$\mathbf{F}-\mathbf{4}$

PROJECT REPORT

After completing the simulation, field work and planning effectiveness will be analyzed in a report. The report will include:

- Appropriateness of selected equipment

- Potential problems averted

- Equipment perfected

- Equipment settings

- Test results

- Work procedures developed

- Safety requirements identified

See Appendix B for suggested report outline. 

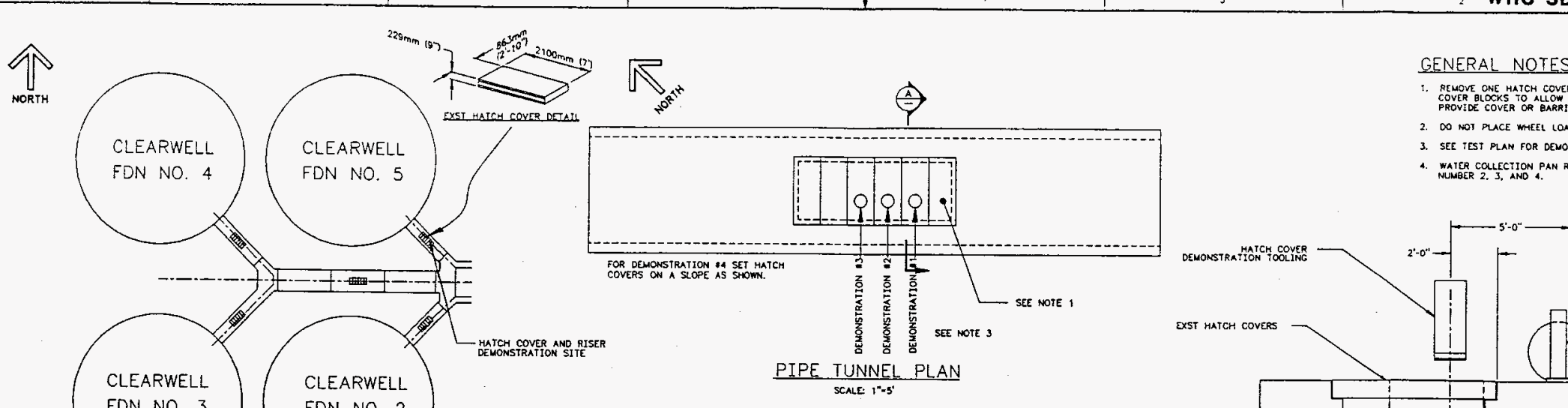
CLEARWELL
FDN NO. 3
FDN NO. 2

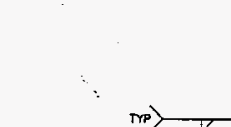
MTIN BENO RAD SCALE: $t^{n-5}$

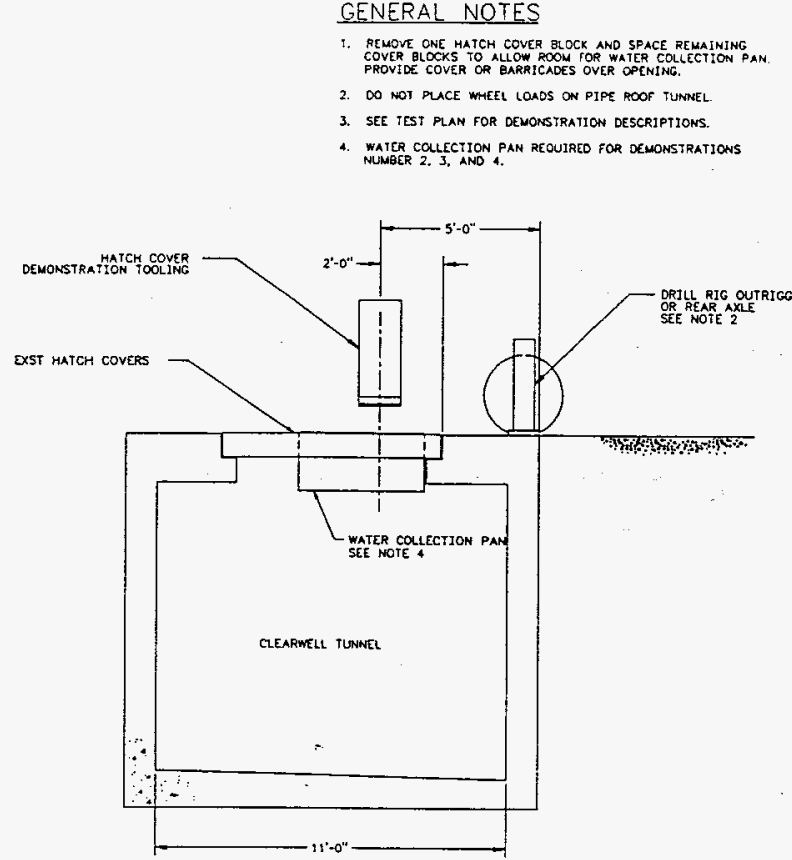

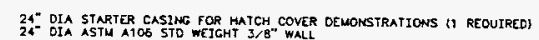
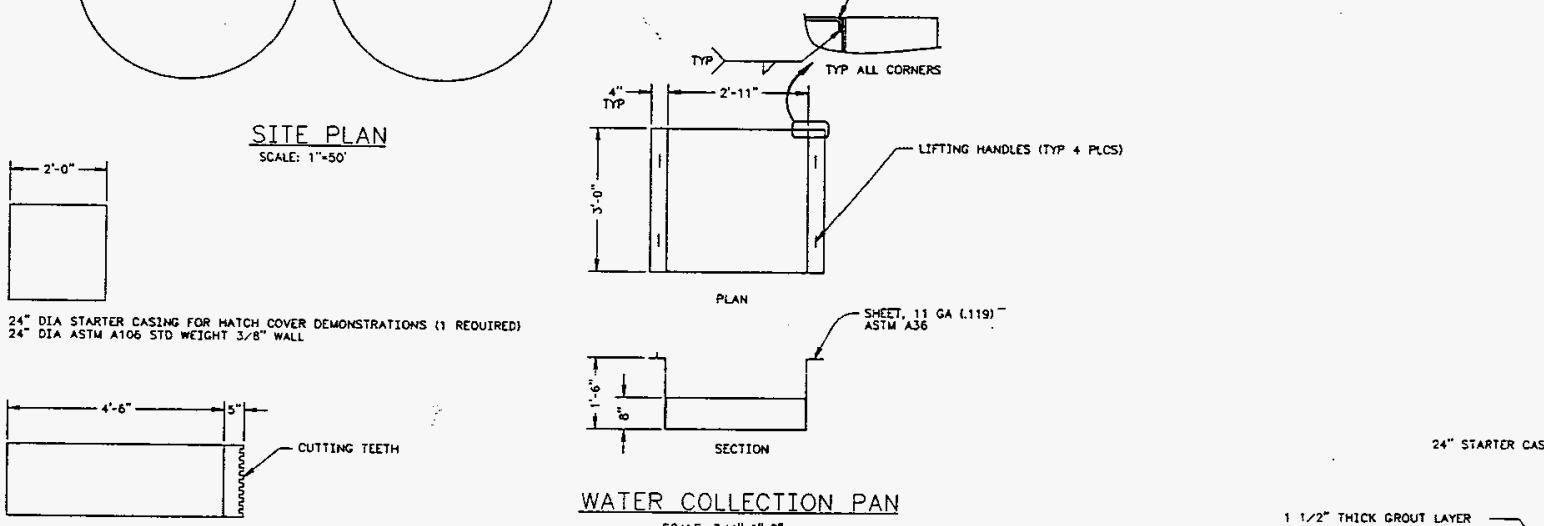

$\frac{\text { WATER COLLECTION PAN }}{\text { SCIE }}$

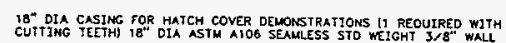

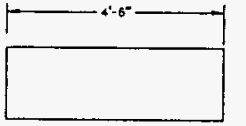

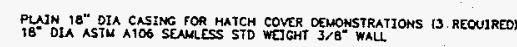

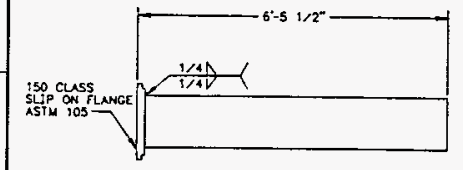

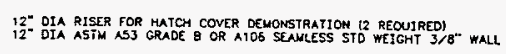

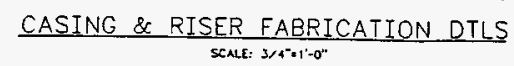

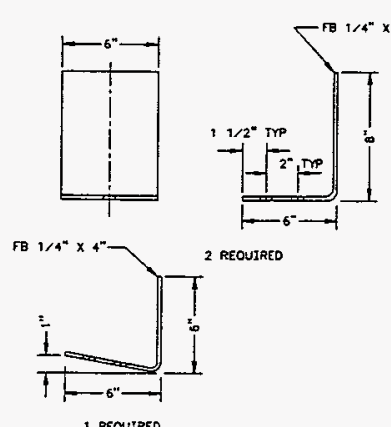

1 REOURED

STARTER CASING SUPPORT DETAILS

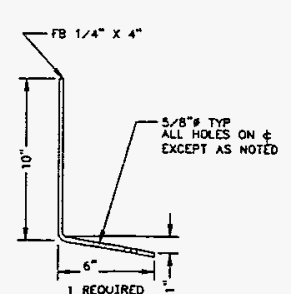

$\operatorname{sen} 3^{*}=1^{*}-0^{*}$

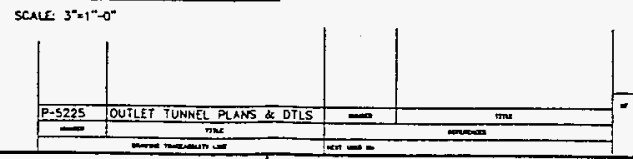

PRELIMITANC

(4) $\frac{\text { SECTION }}{1,2-2=1-0^{-0}}$

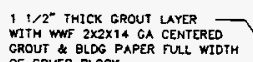

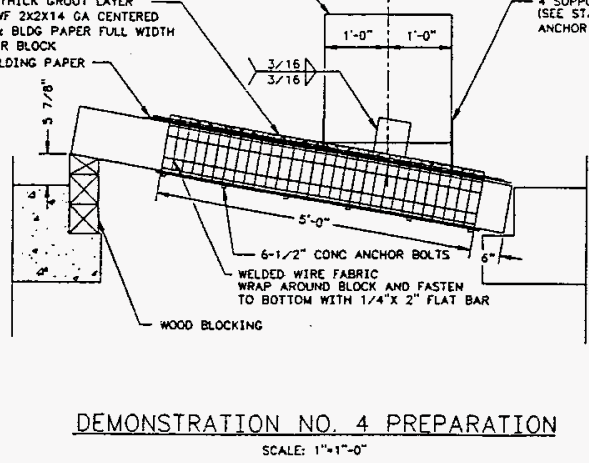

SCALE: $1 * 1^{*}+0^{-}$

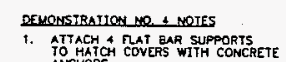

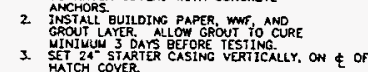




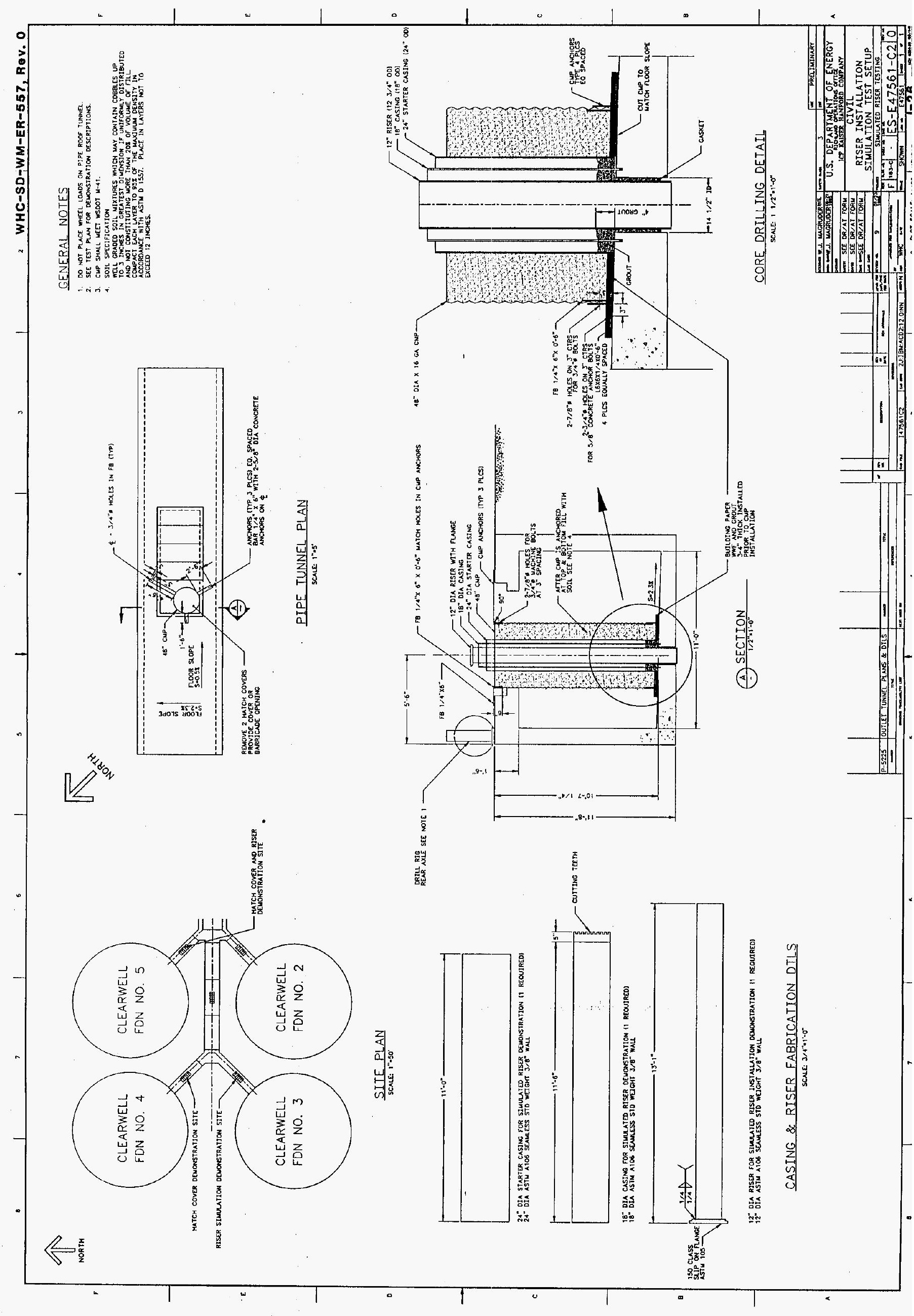




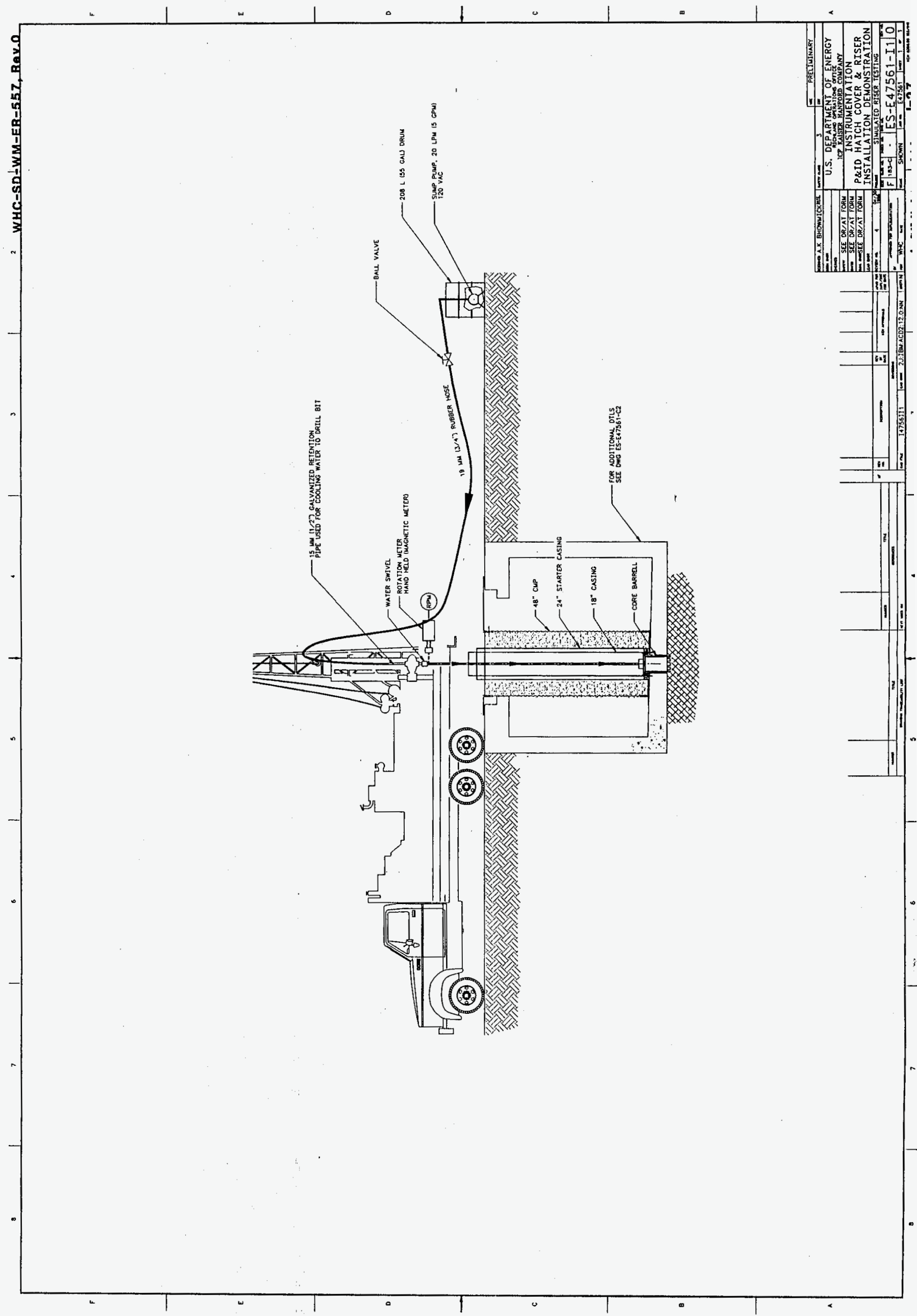




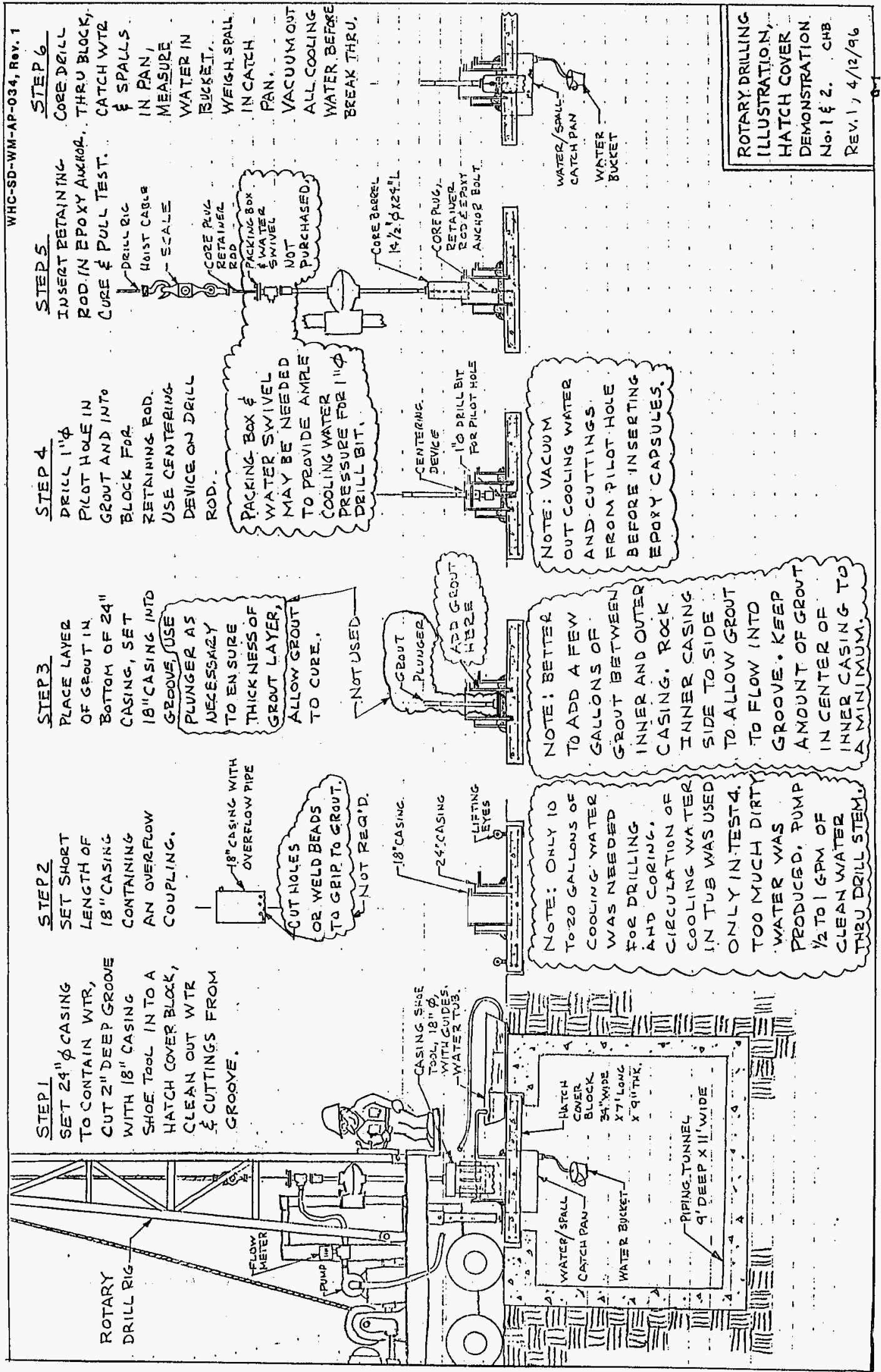




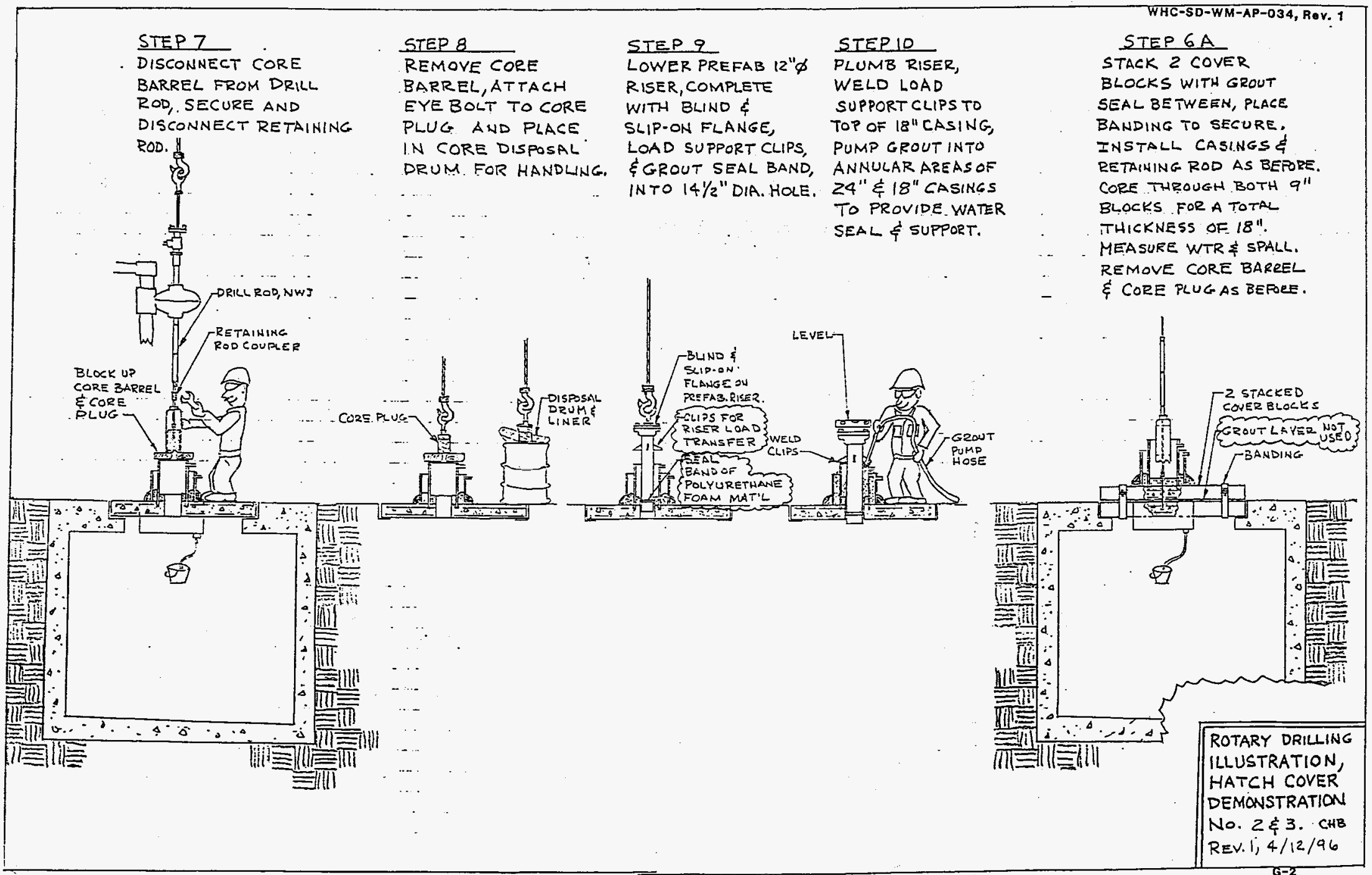




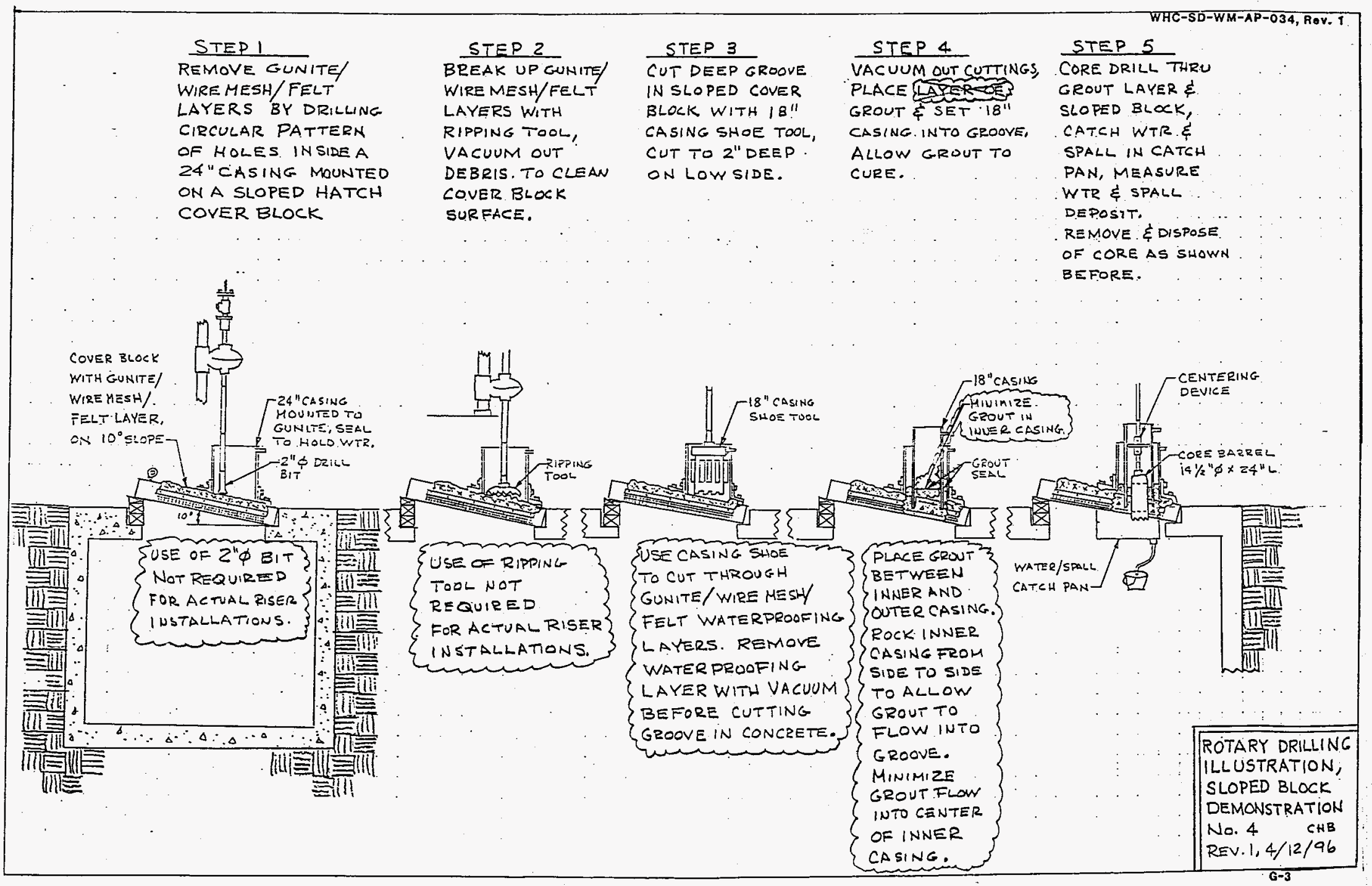




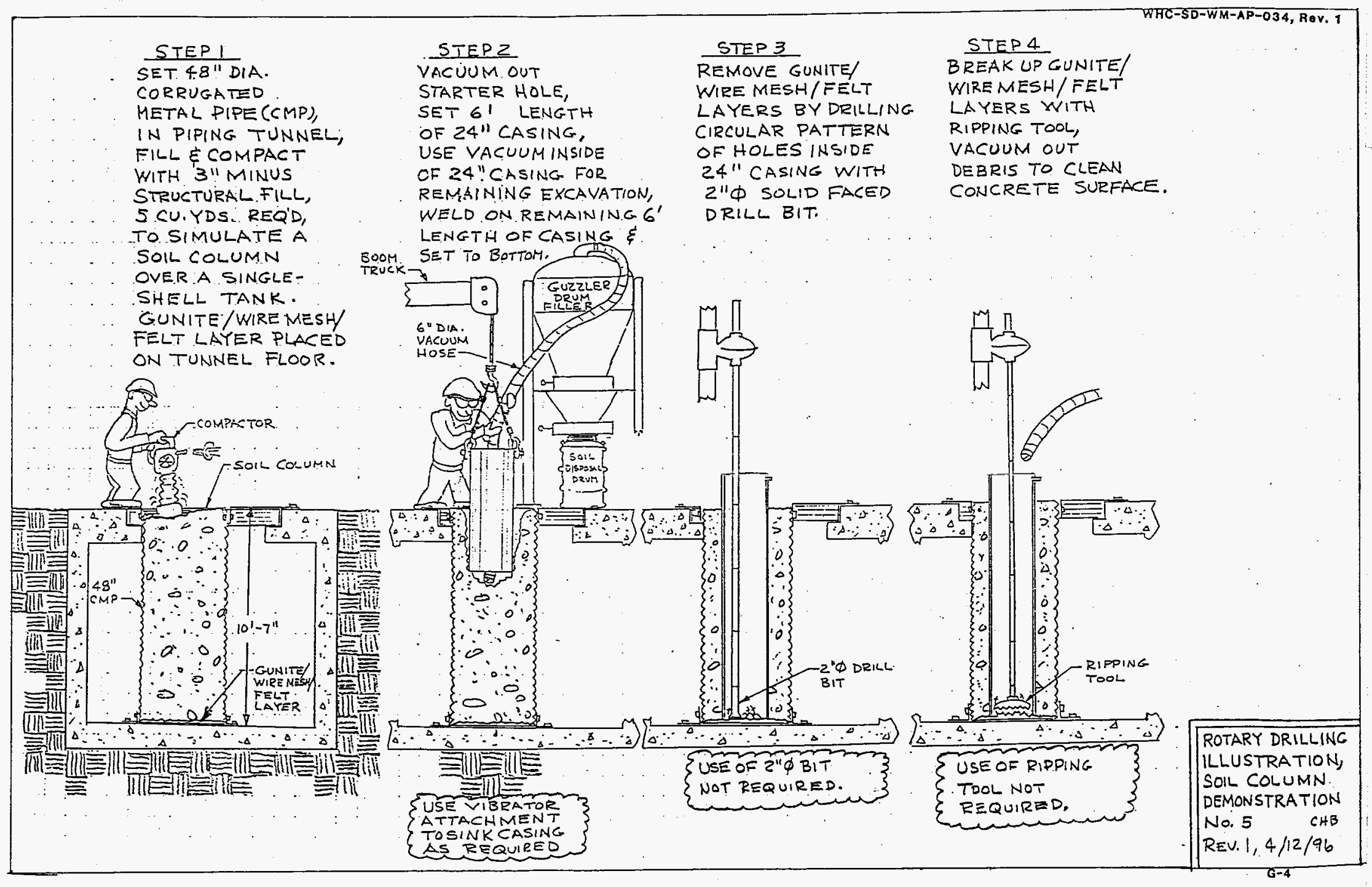




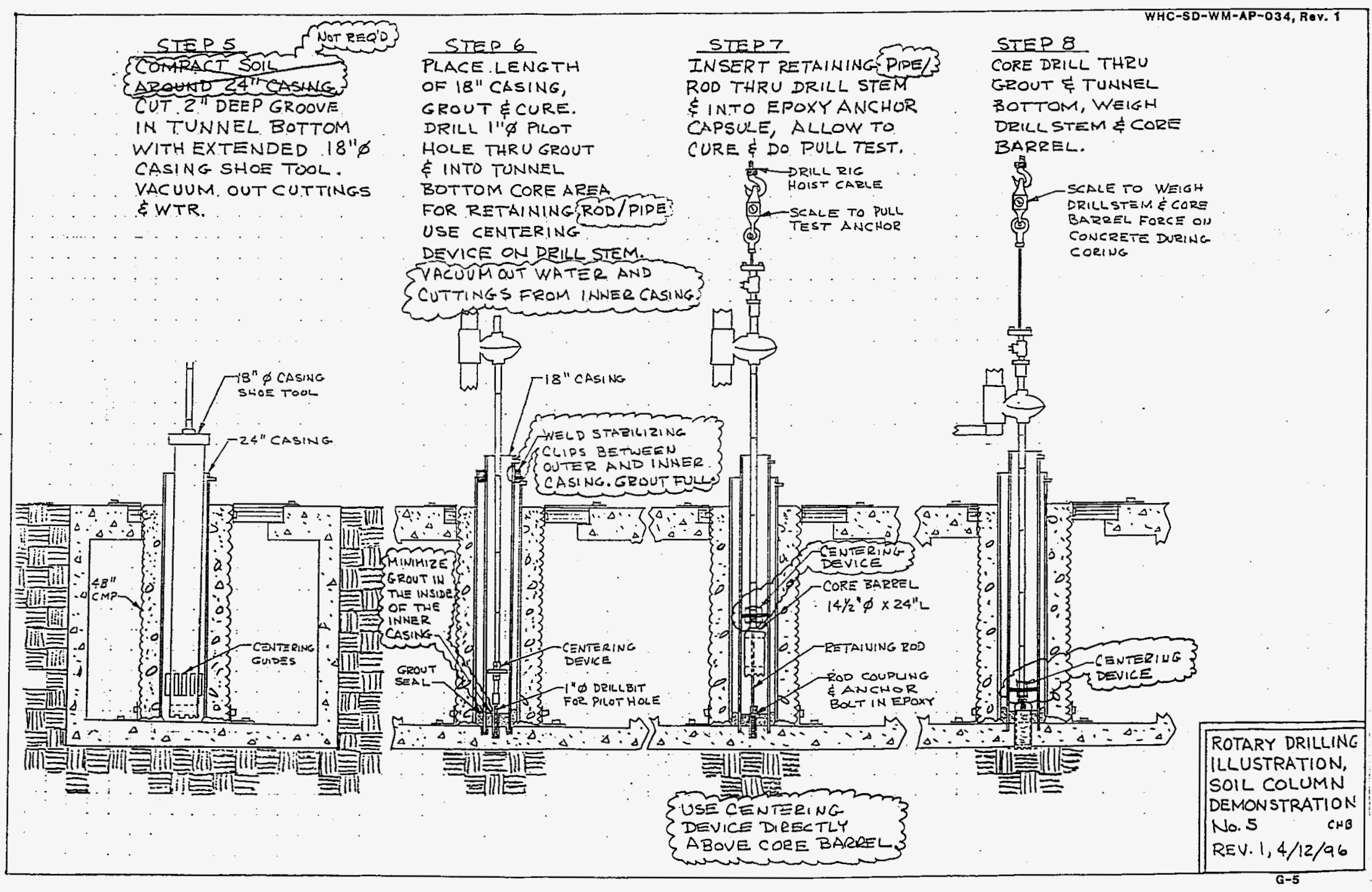




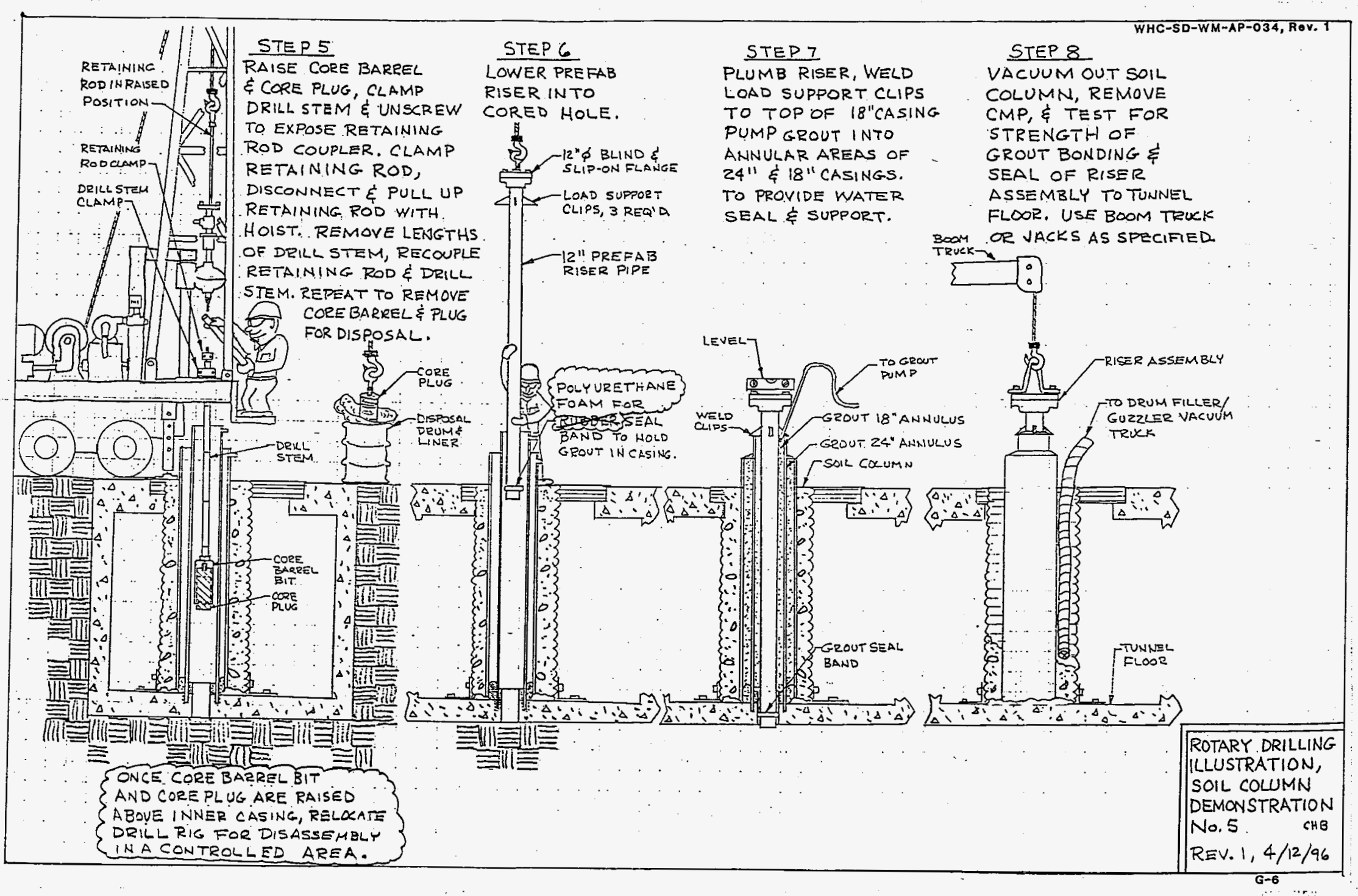




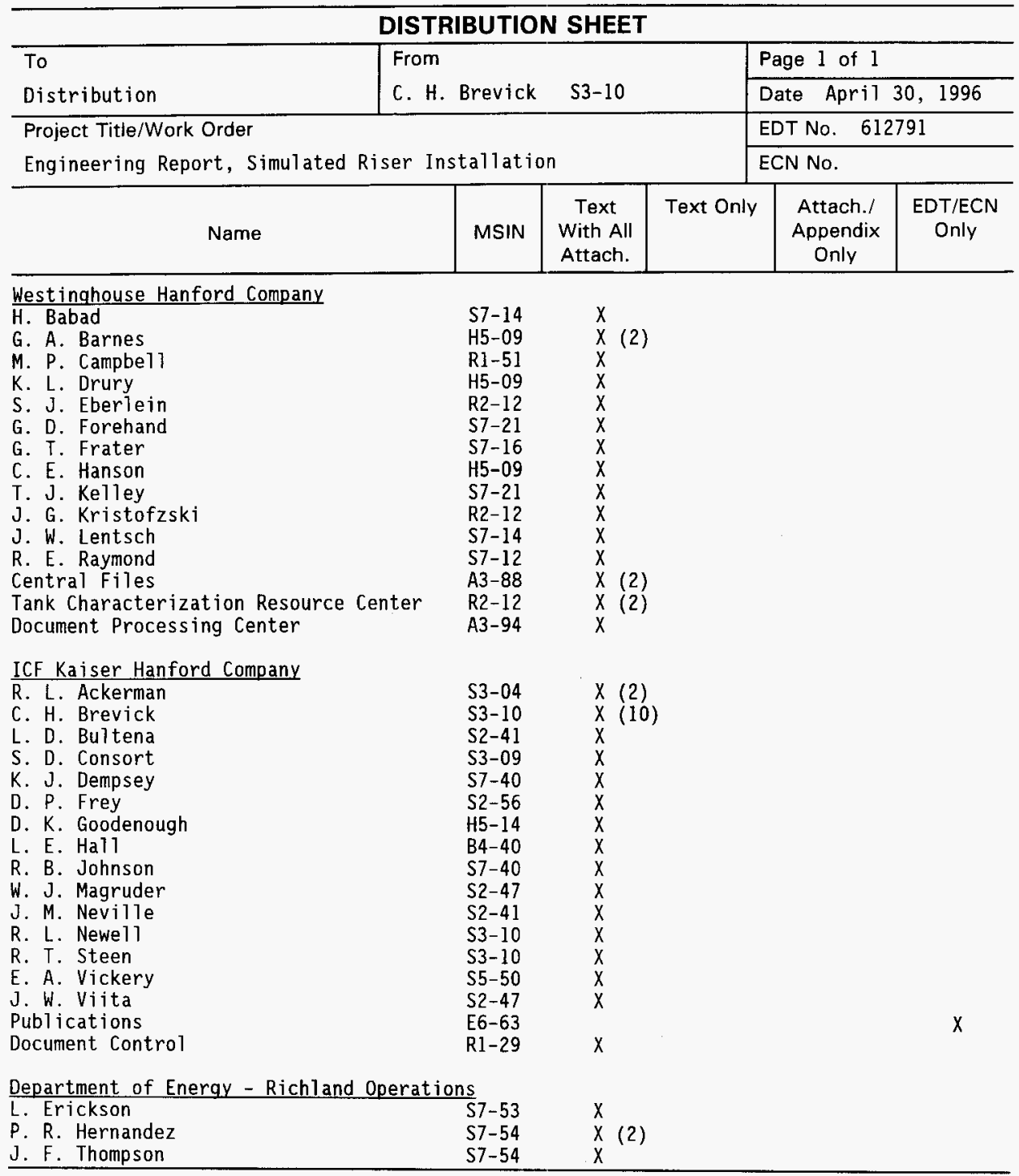

